Historic, Archive Document

Do not assume content reflects current scientific knowledge, policies, or practices. 



\section{LANDSCAPE ARCHITEC'TS}

$\mathrm{B}^{\mathrm{EFORE}}$ any home is built, a landscape archi$\mathrm{B}_{\text {tect }}$ should be consulted concerning the development of the property. In remodeling or rebuilding older places, experienced landscape service will be of inestimable value.

It is our business to make complete plans for large or small properties, estates, and parks. We furnish detailed specifications and estimates for each job, and supply necessary supervision.

For small places we can work from a plan drawn to scale, with a few snapshots of the site or the present property. For larger undertakings, where the work will be extensive, a visit and consultation are necessary. This can be arranged on reasonable terms.

\section{ELLIOTT AND LEONARD}

\section{Landscape Architects}

Magee Building, 336 Fourth Avenue, PITTSBURGH, PA.

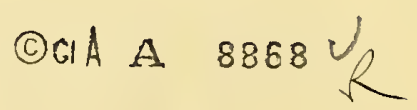




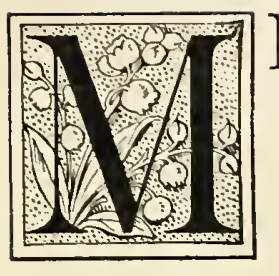

\section{R. J. WILKINSON ELLIOTT, of Pittsburgh, founded this firm in 1890 .}

It has outgrown its facilities several times, until it was necessary to establish a completely new nursery with new office and warehouses at Evans City, Pa., 23 miles from Pittsburgh on the B. $\sigma$ O. R. R., interurban lines, and improved highways.

The grounds about the office have been developed as a show room, and in the spring the display of tulips, other spring bulbs, and shrubs will be worth traveling miles to see. You are cordially invited to come and enjoy the flowers with us, and to repeat your visit later when the nursery fields will be even more interesting.

The present officers of the firm are: R. F. Elliott, President; S. W. Leonard, Vice-President; Florence Wise, Secretary; and C. H. Sample, Treasurer. They have all grown up in the methods and traditions of this organization and have a personal interest in seeing that orders receive intelligent, rapid, and accurate handling.

This year, we have completely revised our Catalogue as you will see. Plants have been classified according to the way they can best be used, instead of by the botanical system. We trust that those who are untrained in botanical nomenclature will find it interesting reading and easy to order from. The Index has been very carefully compiled, however, in order that plants may be quickly found by their botanical names if so desired.

We are prepared to give better service now than ever before, and hope that we may have the opportunity to convince our old customers and a great many new friends of this fact.

\section{ELLIOTT NURSERY COMPANY PITTSBURGH, PENNA.}




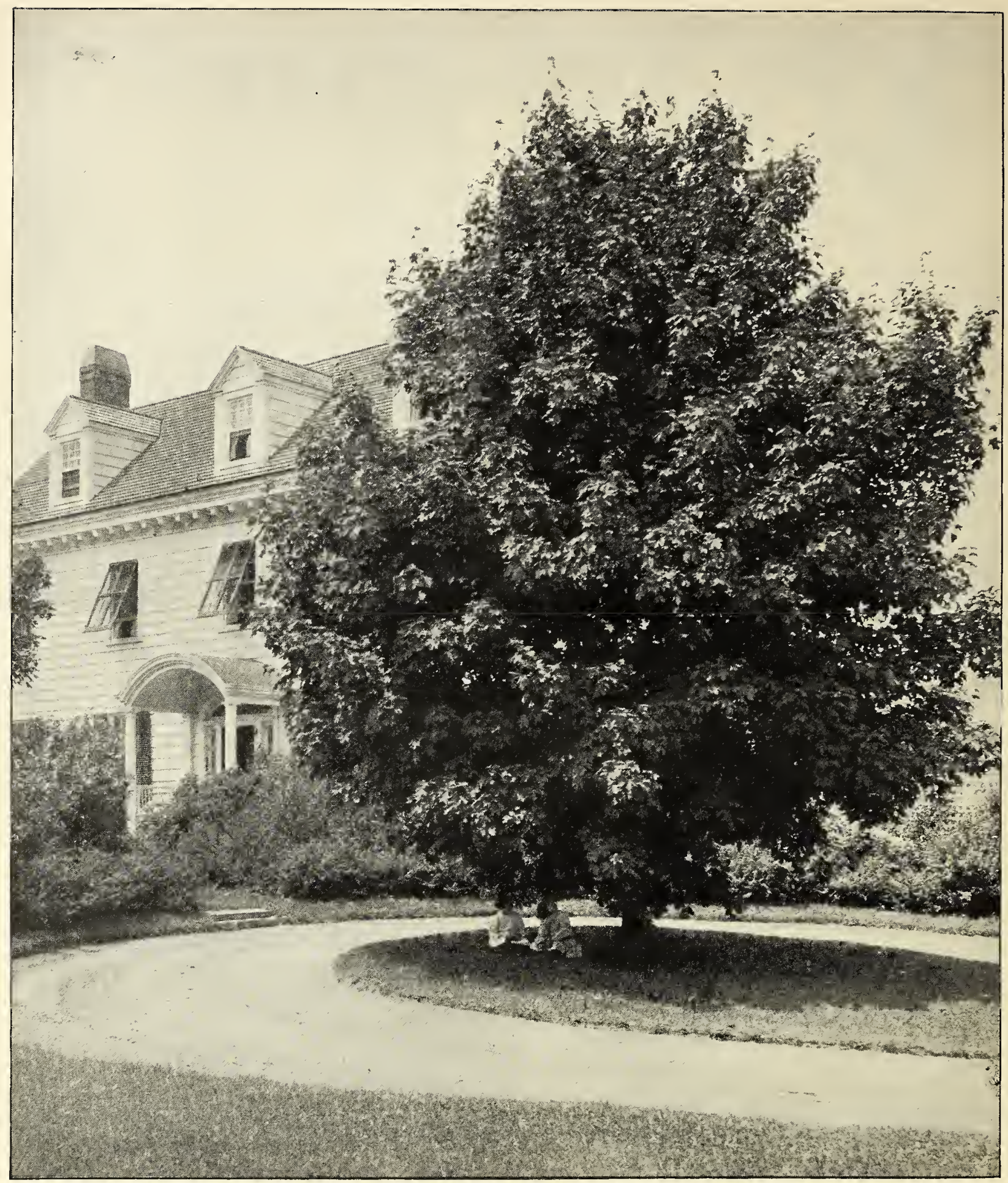

Sbade Trees make a bome livable. Tbis Norway Maple (Acer platanoides) adds mucb to the appearance and value of tbis property and makes a sbeltered playground for the cbildren 


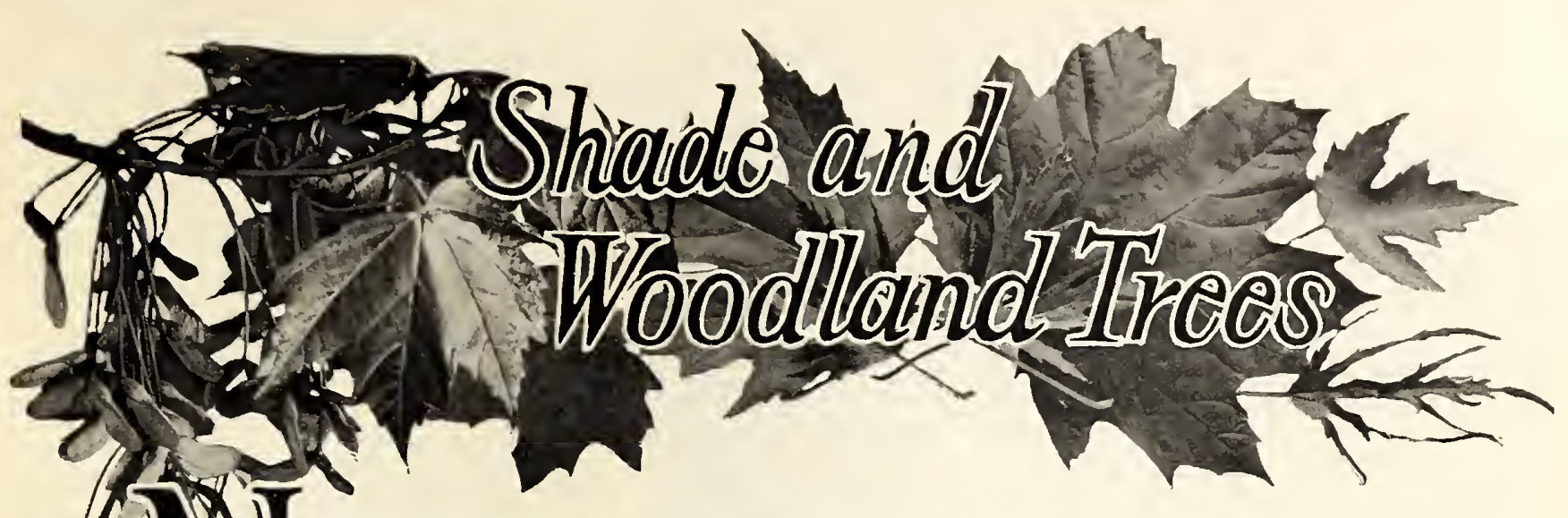
DO MATTER how large or small the grounds about a home, the most impor-
tant thing in planting is to choose the proper trees.

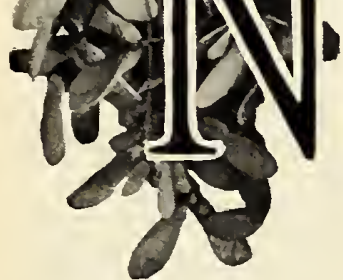

The trees described in the text are offered in tbis column, as well as many otber interesting and beautiful species. For varieties not listed in tbis Section, consult Index.

Birch • Betula

Canoe Birch. Betula papyrifera. A Jarge tree with white trunk and loose, graceful head. 6 to $8 \mathrm{ft}$., $\$ 2.50$ each.

European White Birch. B. alba. Similar to the Cutleaf Weeping Birch except that the leaves are not so deeply cut and its habit is a trifle more erect. 6 to $8 \mathrm{ft}$., $\$ 2.50$ each.

American White Birch. B. populifolia. Small, very graceful tree with snow-white bark; often forms clusters of several trunks of utmost decorative value. Thrives in sterile, stony places. 6 to $8 \mathrm{ft}$., $\$ 2.50$ each.

For otber Bircbes, consult Index

\section{Cedar $\cdot$ Juniperus}

The trees described here are really Junipers, but as they are commonly called Cedars, they are listed here for convenience. For other Junipers, see Index. Blue Virginia Cedar. Juniperus virginiana (glauca). A slender, very graceful tree similar to the Red Cedar described below, but the foliage has a silvery, gray-blue tinge. $2 \mathrm{ft}$., $\$ 4.75$ each.

Red Cedar. J. virginiana. Slender, compact evergreen trees of great beauty, either as specimens at chosen points or in a line to make a screen. 30 to 36 in., $\$ 4.50$ each.

\section{EIm • UImus}

American Elm. Ulmus americana. Stately, graceful trees of great size, with upward swinging branches and a round, graceful top much broader than the base. A wonderful avenue tree and splendid as an isolated specimen. 8 to $10 \mathrm{ft}$., $\$ 3$ each, $\$ 30$ for 12 .

Moline Elm. U. americana (molini). An erect and compact tree without the branching trunk of the type, and a fine, quick-growing street tree. 8 to $10 \mathrm{ft} ., \$ 3.50$ each. described in the section of this book devoted to Ornamental Trees, but occasionally there is room for a handsome tree of greater stature. We have seen at least one fine back-yard garden which consisted entirely of one dense, shady Norway Maple under which was a little artificial pool surrounded by irregular flagging, upon which a few potted ferns and flowers were tastefully distributed. Everything depends upon the space available, but some trees there must be, or the place will have an empty, unfinished appearance.

If a strip of ground along a city street is to be planted, tough, drought-resistant, thoroughly domesticated trees, like Norway Maples, European Planes, or Ginkgos ought to be used. Such trees grow rapidly and are inured to the adverse environment of city life. Lombardy Poplars thrive under such conditions, but are too slender and tall to provide much shade. They are more suitable for picturesque effects in the country, although a group of them at the end of a city lot or on a property line has a special kind of beauty.

If the home is in the suburbs where the air is clean and the lot large, there is much more scope for planting design and wider choice of trees. Generally they should be grouped to the sides and back of the house and kept out of the direct line of vision toward the street. The object is to frame the house in foliage, softening its architectural lines by rising between them and the sky, or by continuing them in soft, rounded masses of verdure. The height and shape of the trees are therefore important things to know.

In the grounds to the rear, an individual specimen, such as a handsome EIm or one of the finer Maples, may be used; perhaps several together a little distance from the house. They should not be dotted about at regular intervals like orchard trees, but grouped irregularly around the edges as they would grow if Nature had planted them.

In the suburbs or country the air is generally clean enough to use evergreens such as Spruces, Hemlocks, Pines, and Cedars. 


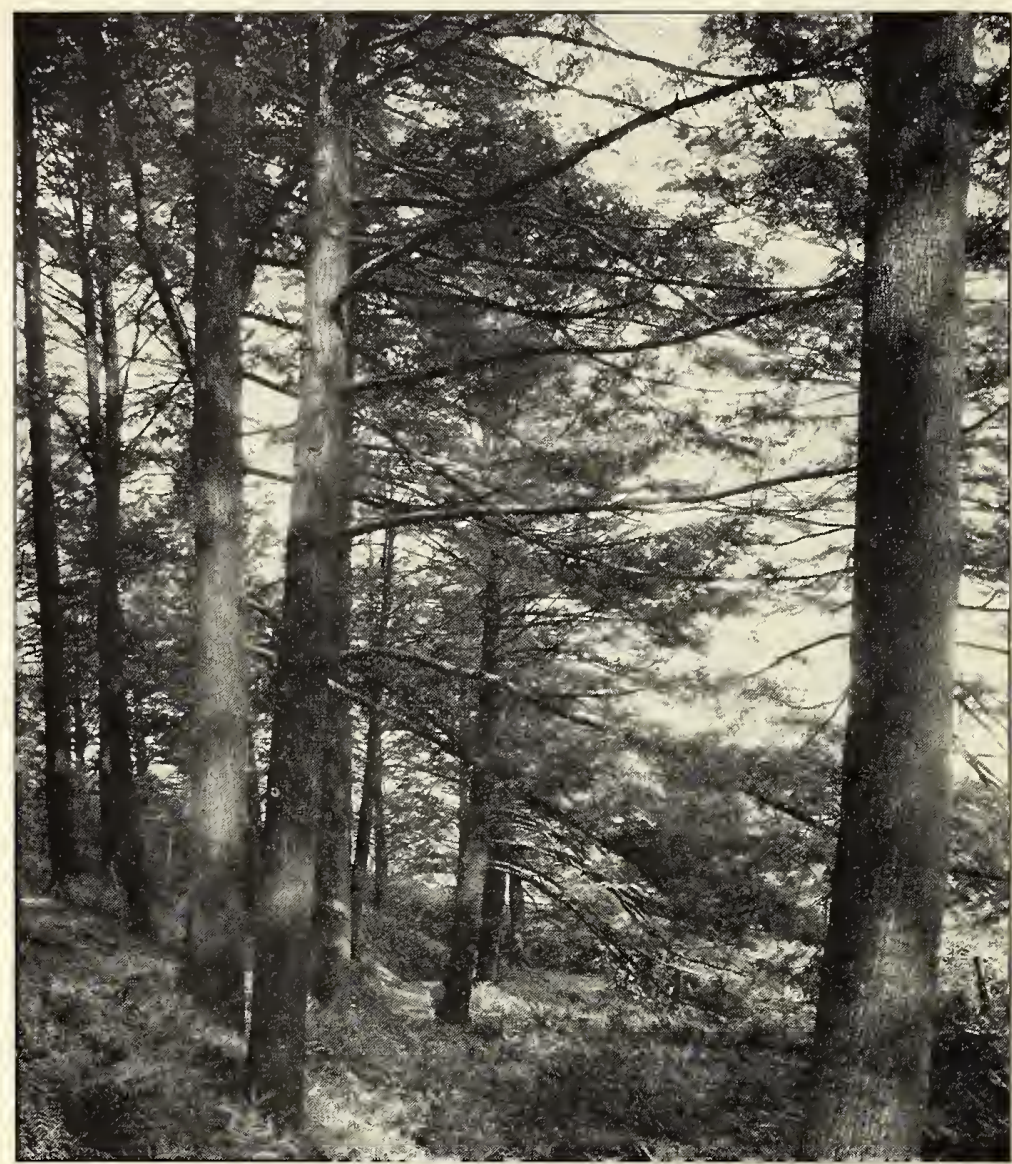

Hemlocks as Nature grows them. A plot of ground reforested in this way will be of inestimable value

They are disappointing in the midst of cities because of gas and smoke, but thrive vigorously where the air is pure. Use evergreens liberally because of their beautiful forms and attractive color in winter; but they should not be planted close to the house. Deciduous trees, Iike EIms and Maples, are better in such situations, because they lose their foliage in autumn and do not darken the windows if planted nearby; but large Pines or Hemlocks are very gloomy if their heavy foliage shuts out the winter sunlight.

As a general rule, most of the fine trees grow slowly. Coarse and vulgar things are fast in their development. Carolina Poplars will grow 30 feet or more in ten years and go to pieces in another ten. While they are alive they acquire and practice every despicable habit known to horticulture. On the other hand, a White Oak may take the better part of a century to develop, but, after it has developed it is magnificent for another two centuries. Consequently, if it does seem necessary to have trees that will develop over night, one must be content with things which are secondrate and shoddy.

An exception is to be noted in favor of Salamon's Weeping Willow, which is an extremely rapid grower and a tree of great beauty, dignity, and permanence. It is one of the few very fine things which may be quickly and easily had.
Fir - Abies

One of the trees listed here is not a true Fir, as will be noted.

Douglas Fir. Pseudotsuga douglasi. A giant evergreen forest tree of great beauty. It grows very rapidly and should be planted in groups for best effect. 18 to 24 in., $\$ 3$ each; 30 to 36 in., $\$ 5$ each.

White Fir. Abies concolor. Handsome, compact evergreen of tall growth. Foliage with a strong bluish gray cast. 18 to 24 in., $\$ 6$ each; 30 to 36 in., $\$ 9$ each.

Ginkgo • Ginkgo

Ginkgo (Maidenhair Tree). Ginkgo biloba. One of the noblest specimen trees, and especially good for street planting. Highly resistant to diseases and insects. The curious fan-shaped leaves are different from any other tree known. 6 to $8 \mathrm{ft}$., $\$ 3$ each.

\section{Hemlock • Tsuga}

Carolina Hemlock. Tsuga caroliniana. A compact tree with dark foliage and considered by some superior to the northern $T$. canadensis. 18 to 24 in., $\$ 4.50$ each.

Canada Hemlock. T. canadensis. The most graceful and generally beautiful evergreen. It has broad, sweeping branches and an upward lilt like a bird song. Give it plenty of room. 30 to 36 in., $\$ 4$ each, $\$ 40$ for $12 ; 36$ to 42 in., $\$ 5$ each, $\$ 50$ for 12 .

\section{Horse-Chestnut • Æsculus}

Horse-Chestnut. Asculus bippocastanum. Medium-sized tree with large, dense foliage and extremely compact head. The spikes of flowers are very attractive in spring, and in autumn the ground is covered with its gorgeous mahoganyred nuts. 5 to $6 \mathrm{ft}$., $\$ 3$ each.

\section{Juniper}

For shade trees of this family, see Cedar; others will be found among the Ornamental Trees and the Decorative Shrubs.

\section{Larch • Larix}

European LARCh. Larix europæus. A very graceful tree of the Spruce type but sheds its needles in autumn. 4 to $5 \mathrm{ft}$., $\$ 2.50$ each; 5 to $6 \mathrm{ft}$., $\$ 3$ each.

\section{Maple - Acer}

Norway Maple. Acer platanoides. A very popular shade tree with a dense head, widely used for street planting. It is not good to have in or near the garden because of its voracious roots and the nuisance of its seedlings. 8 to $10 \mathrm{ft}$., $\$ 4$ each.

Silver Maple. A. dasycarpum. One of the choicest. large trees with an immense head. Leaves are
whitish underneath. 8 to $10 \mathrm{ft}$., $\$ 2.50$ each, $\$ 25$ for 12.

Sugar Maple, A. saccharum. A good street or lawn tree with fine foliage which turns yellow and scarlet in autumn. It does not like wet ground. 8 to $10 \mathrm{ft}$., $\$ 4$ each.

\section{For otber Maples, consult Index}

\section{Oak • Quercus}

PIN OAK. Quercus palustris. A very handsome, symmetrical tree with deeply cut leaves. It grows rapidly for so permanent a tree and has great dignity and beauty. Good street tree and for grouping. 6 to $8 \mathrm{ft}$., $\$ 4$ each; 8 to $10 \mathrm{ft}$., $\$ 5$ each. 


\section{Pine - Pinus}

Austrian Pine. Pinus nigra. A bold, robust, and rather coarse evergreen trcc, with tremendous picture value in the landscape. It grows rapidly and is desirable for specimen planting or for large groups. 18 to 24 in., $\$ 2.50$ each; 2 to $3 \mathrm{ft}$., $\$ 4$ each.

Scotch Pine. P. sylvestris. More graceful than the foregoing, with silvery gray-green needles and an open, picturesque habit. Suitable for specimens or large groupings. 18 to 24 in., $\$ 2.50$ each; 2 to $3 \mathrm{ft}$., $\$ 3.50$ each.

For otber Pines, consult Index

\section{Plane Platanus}

European Plane. Platanus orientalis. A handsome, tough, drought-resistant, street tree which grows rapidly and lives under trying city conditions. Very widely planted in cities. 8 to $10 \mathrm{ft}$., $\$ 3$ each; 10 to $12 \mathrm{ft}$., $\$ 1.50$ each.

\section{Poplar • Populus}

Lombardy Poplar. Populus nigra (italica). One of the most decorative trees in the world; tall, very slender, and column-like. Wonderful in small groups or for screen planting. 6 to $8 \mathrm{ft}$., $\$ 1$ each, $\$ 10$ for $12 ; 8$ to $10 \mathrm{ft}$., $\$ 1.50$ each, $\$ 15$ for 12 .

Meyer's Poplar. $P$. meveri. A dense, columnar tree of similar type but better in all respects. Roots do not damage sewers. 5 to $6 \mathrm{ft}$., $\$ 1.75$ each; 7 to $9 \mathrm{ft}$., $\$ 2.50$ each.

\section{Spruce • Picea}

Blue Colorado Spruce. Picea pungens (glauca). A lof ty evergreen tree for large groups or specimen use. The foliage is rich, dark grayish green or blue. 30 to 36 in., $\$ 10$ each.

Norway Spruce. $P$. excelsa. Strong, symmetrical evergreens of rapid growth, suitable for groves or avenue planting. A little too coarse for a good specimen tree. 18 to 24 in., $\$ 2.50$ each, $\$ 25$ for 12 ; 2 to $3 \mathrm{ft}$., $\$ 3$ each, $\$ 33$ for 12 .

White Spruce. P. canadensis. Of moderate height, very dense and ornamental when young; foliage bright grayish green. Withstands drought and unfavorable conditions better than most evergreens. 18 to 24 in., $\$ 2.50$ each, $\$ 25$ for 12 ; 2 to $3 \mathrm{ft}$., $\$ 3$ each, $\$ 33$ for 12 .

For otber Spruces, consult Index

\section{Willow . Salix}

Babylon Weeping Willow. Salix babylonica. Tree of medium size with long, slender, drooping branches. Looks well as isolated specimens along water-course or ponds. Not a lawn tree or a tree for grouping. 6 to $8 \mathrm{ft}$., $\$ 1.50$ each.

Bronze Willow. S. vitellina (britzensis). A form of the common Yellow Willow, with large, round head and bronzy red branchlets. 4 to $5 \mathrm{ft}$., $75 \mathrm{cts}$. each, $\$ 7.50$ for 12 .

Golden Weeping Willow. S. vitellina (pendula). A beautiful weeping form of the Golden Willow. Attractive in low, moist places or along streams. 6 to $8 \mathrm{ft}$., $\$ 1.50$ each.

Salamon's Wefering Willow. S. salamoni. An exceptionally quick-growing tree, not as drooping as other weeping types. It leafs out very early in spring and we consider it one of the most valuable trees for decorative landscape use. 1-yr. trees, $\$ 1.25$ each, $\$ 12$ for 12 , \$75 per 100; 2-yr., \$1.75 each, $\$ 18$ for 12 , $\$ 110$ per 100 . (This is the most popular Willow.

For otber Willows, consult Index

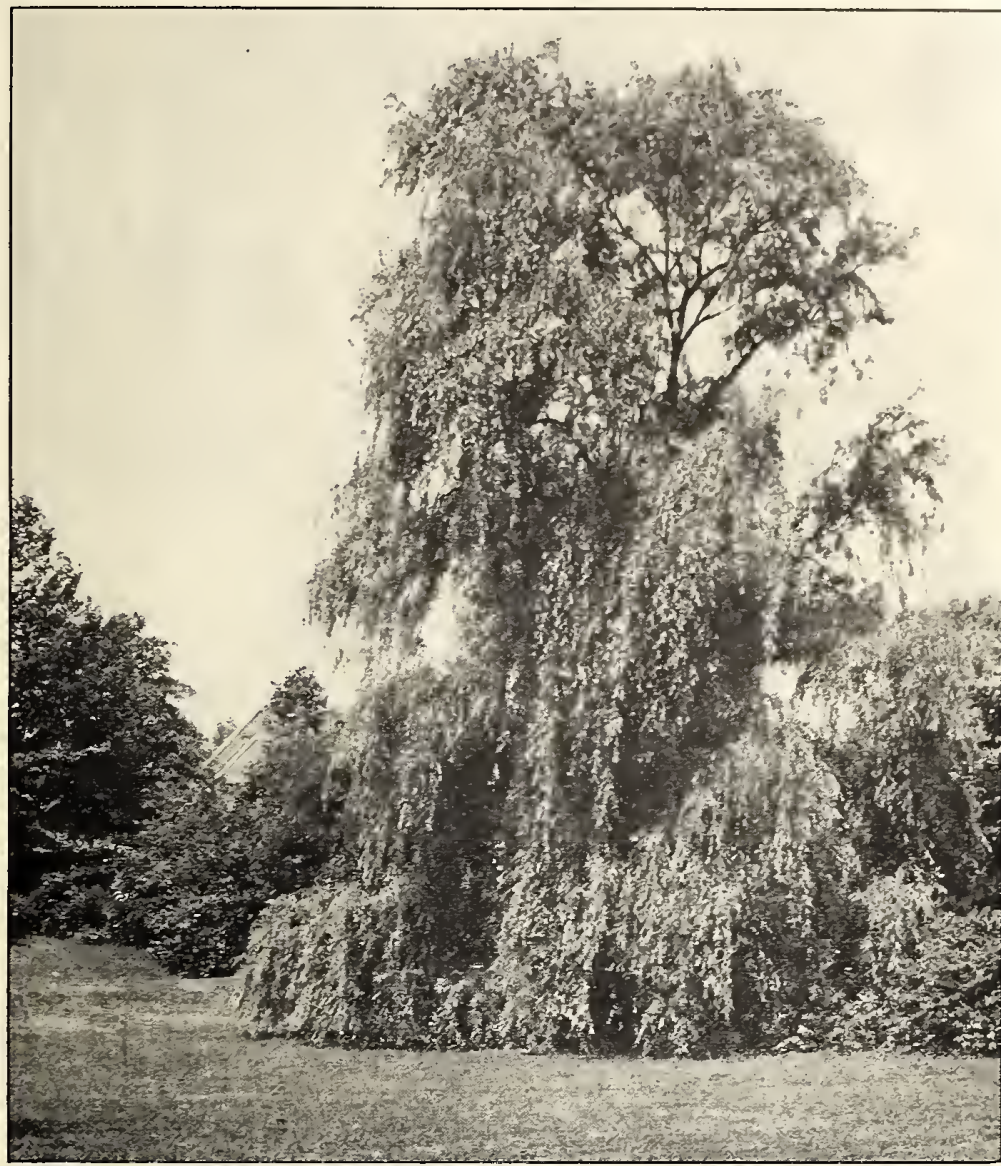

Salamon's Weeping Willow sbowing its graceful form displayed against a supporting background of lower trees and sbrubs

One of the gravest forms of abuse to which deciduous trees and shrubs can be subjected is to plant them without pruning. Depending upon the character of the plants, they should be cut back one-fourth to one-half, and all the weak or secondary branches removed entirely; but do not cut out the central stem or leader.

AII plants feed only through microscopic organs at the tips of the roots. The rest of the root-system serves as channels to convey food where it is needed. It is impossible to dig a plant without destroying these feeding-points. Consequently, if a tree or shrub is not pruned when it is dug up and replanted, the top is often greater than it can support.

Evergreen trees and deciduous trees which have their roots balled and burlapped should not be pruned.

If you want your nurseryman to consider you an intelligent person, do not write to him when a plant dies, complaining that it was planted by an experienced gardener who says that it was defective when he planted it. Competent horticulturists do not waste time planting defective material. A gardener who would is either an ignoramus or a fraud. Your nurseryman is just as much interested in your horticultural problems as you are, and is concerned in finding solutions for them. He always welcomes suggestions from horticulturists of known experience and skill. 

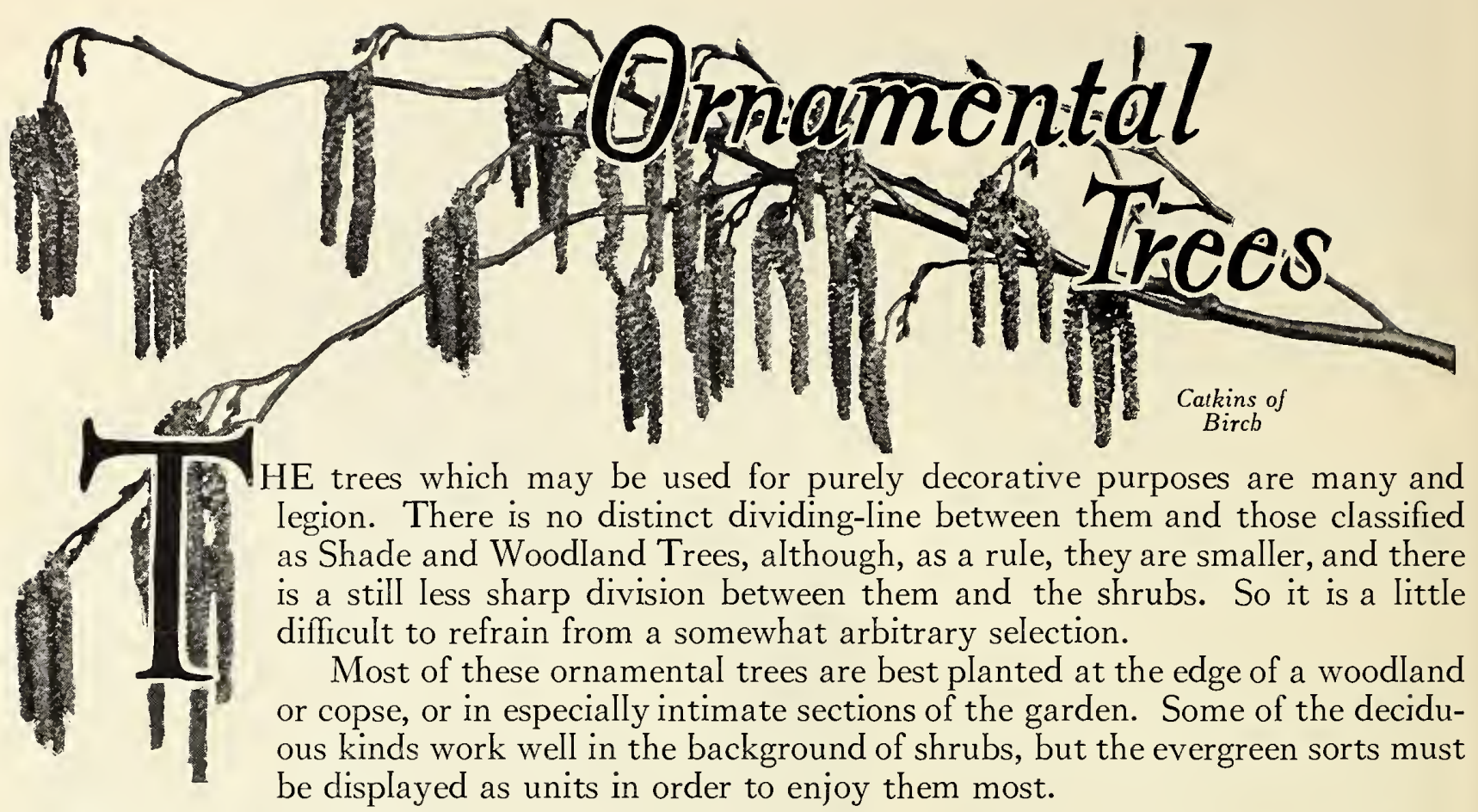

Many trees are valued chiefly for their distinct shape: the Lombardy Poplar, already mentioned, is a fine example. Almost all the Evergreens are greatly admired for their symmetry, although the permanent nature of their foliage and the various color values which they afford add much to their desirability.

The Yews are the finest subjects in this group. Of imposing dignity, if allowed to grow naturally, they may be made to assume any form by judicious shearing; and the dark, almost black foliage is the most impressive of any tree we know. Frequently the very dark branches are enlivened by brilliant rose-red fruits like little gumdrops; and the yellow tips of the shoots in spring are more decorative than many flowers.

The hardy Cypresses, sometimes called Retinosporas, are, perhaps, next most valued for their texture and form. They are extremely formal and dignified, especially if properly clipped, and their color-range is infinitely varied, not only by the pigmentation of the foliage but by the interplay and inter-reflection of light among their dense, feathery branches.

Even more rigid and soldier-like are the Arborvitæs, which duplicate in the evergreens somewhat the same exclamatory note which distinguishes the Lombardy Poplar, except that they are seldom so Iofty, and have much more solidity and permanence. Frequently, the Arborvitæs are used for hedges because they can be easily kept within bounds, and are very resistant to unfavorable conditions.

For very special, artificial designs, the showy flamboyance of the Umbrella Tree is useful; and the Weeping Mulberry is very effective when properly placed in the angle of a wall, or close to some architectural feature.

The beauty of all these trees can be brought out properly only against some background which throws their shape into sharp relief. In the case of the Arborvitæs, it may be the sky, because of their soaring, lifting trend, but most of the others seem to want to snuggle into a protected garden or against some Iower shelter.

\begin{abstract}
The trees described in the text, as well as many otber interesting and beautiful species, are offered in tbis column. For varieties not listed, consul the Index.
\end{abstract}

\section{Arborvitæ - Thuja}

American Arborvite (White Cedar). Tbuja occidentalis. Evergreen, compact, tall, spire-like. 18 to 24 in., $\$ 2$ each; 30 to 36 in., $\$ 3$ each; 3 to $4 \mathrm{ft}$., $\$ 4.50$ each.

Douglas' Pyramidal Arborvite. T. occidentalis. Columnar tree with dense, fern-like foliage. Very fine. 18 in., $\$ 2.50$ each.

Mossy Arborvite. $T$. occidentalis $w z$ eana (plicata). Dark, bronzy green foliage, very crisp and mossy. Tree slender and compact. 18 in., $\$ 3$ each; 24 in., $\$ 4$ each.

Peabody's Arborvite. $T$. occidentalis. A fine pyramidal form with bright yellow foliage. 24 to 30 in., $\$ 4.50$ each.

Pyramidal Arborvita. $T$. occidentalis. Slender, very compact, almost columnar form. 18 to 24 in., $\$ 3$ each; 30 to 36 in., $\$ 4.50$ each.

Rivers' Arborvite. $T$. occidentalis. Similar to foregoing, but foliage bright yellowish green. 18 to 24 in., $\$ 3$ each; 2 to $3 \mathrm{ft}$., $\$ 4.50$ each.

Rosenthal's Arborvita. T. occidentalis. Narrow and compact, with very dark, lustrous foliage. 18 to 24 in., $\$ 3.50$ each.

Birch - Betula

Cutleaf Weeping Birch. Betula alba laciniata. Moderate size; white bark; branches very slender and drooping; foliage finely cut. 6 to $8 \mathrm{ft}$., $\$ 5$ each.

Cherry • Prunus

Japanese Weeping Cherry. Prunus subbirtella (pendula). Small tree with weeping branches, pink flowers in early spring. 1-yr. head, $\$ 5$ each.

Crabapple • Malus

Bechtel's CRAB. Malus ioensis plena. Large, pale pink flowers in clusters like little roses. Very lovely. 3 to $4 \mathrm{ft}$., $\$ 1.50$ each, $\$ 15$ for 12 . 


\section{CRABAPPLES, continued}

Carmine Crab. $M$. atrosanguinea. Clusters of dark red buds and rose-colored flowers. Very profuse. Fruits dark crimson. 3 to $4 \mathrm{ft}$., $\$ 1.50$ each, $\$ 15$ for 12 .

Japanese Flowering Crab. $M$. floribunda. Completely covered with pink buds and pinkish flowers. Very showy. 3 to 4 ft., $\$ 1.50$ each, $\$ 15$ for 12.

Parkman's Crab. M. balliana. Dark rose-pink, very double flowers on slender purple stems. 3 to $4 \mathrm{ft}$., $\$ 1.50$ each, $\$ 15$ for 12 .

Purple Crab. M. purpurea. Very dark crimson flowers in great abundance. 3 to $4 \mathrm{ft}$., $\$ 1.50$ each, $\$ 15$ for 12 .

Redvein Crab. M. niedzwetzkyana. Dark, redpurple flowers with reddish tinged foliage. Fruit purple. 3 to $4 \mathrm{ft}$., $\$ 1.50$ each, $\$ 15$ for 12 .

SCheIdecker's Crab. M. scbeideckeri. Late flowering. Blooms large, semi-double, pale pink. Fruit yellow. 3 to $4 \mathrm{ft}$., $\$ 1.50$ each, $\$ 15$ for 12 .

Wild Sweet Crab. $M$. coronaria. Small, thorny tree covered with superb, dark rose buds and light pink flowers; intensely fragrant. Fruits greenish. 3 to $4 \mathrm{ft}$., $\$ 1.50$ each, $\$ 15$ for 12 .

\section{Cypress - Chamæcyparis}

These hardy Cypresses are frequently called Retinospora, which is incorrect. The evergreen foliage is exceedingly soft and mossy, and varies through many colors.

Creamy Plumed Cypress. Cbamzcyparis pisifera (plumosa sulpburea). A creamy yellow form. Very distinct. 18 to 24 in., $\$ 3$ each; 24 to 30 in., $\$ 4$ each.

Filifera. C. pisifera. Graceful, drooping, threadlike branches. 18 in., \$3 each; 24 in., \$4.50 each.

Golden Filifera. C. p. (filifera autea). Like the above, but the young growth is golden yellow. 18 to 24 in., $\$ 5$ each; 24 to 30 in., $\$ 6$ each.

Golden Plumed Cypress. C. p. (plumosa aurea). Like Plumed Cypress, with the young growth bright yellow. 18 to 24 in., $\$ 3$ each; 30 in., \$5 each.

Plumed Cypress. C. p. (plumosa). Conical trees with erect, plume-like branches, bright shining green. 18 to 24 in., $\$ 3$ each; 24 to 30 in., $\$ 4.50$ each.

\section{Dogwood • Cornus}

Dogwood. Cornus florida. One of the most beautiful flowering trees. Large white blooms in horizontal sheets all over the tree in mid-spring. 2 to $3 \mathrm{ft}$., $75 \mathrm{cts}$. each, $\$ 8$ for $12 ; 3$ to $4 \mathrm{ft}$., $\$ 1.25$ each, $\$ 12$ for 12 .

Pink Dogwood. C. florida rubra. A Iovely pinkflowered form of the above. Very choice and rare. 4 -in. pot plants, $\$ 2.50$ each; 2 to $3 \mathrm{ft}$., $\$ 5$ each.

\section{Hawthorn - Cratægus}

Cockspur Thorn. Cratægus crusgalli. Very distinct. Fruits bright red; foliage orange and scarlet in autumn. 3 to $4 \mathrm{ft}$., $\$ 1.50$ each, $\$ 15$ for 12 .

Double Pink Thorn. $C$. oxyacantba. A very pretty variety with double, pink flowers. 3 to $4 \mathrm{ft}$., $\$ 3$ each.

Double White Thorn. C. oxyacantba. Similar, with double white flowers. 3 to $4 \mathrm{ft}$., $\$ 3$ each.

Hawthorn. C. oxyacantba. The famous Hawthorn or May of English hedges. Beautiful white flowers. 3 to $4 \mathrm{ft}$., $\$ 1$ each, $\$ 10$ for 12 .

Paul's Scarlet Thorn. C. oxyacantba. A very showy variety with double, brilliant scarlet flowers. 3 to $4 \mathrm{ft}$., $\$ 3$ each.
Most evergreens are to be had in several shades of green and yellow. One should be very careful about using these golden forms. If there are too many, they look cheap and gaudy. The same is true of such fanciful specimens as Koster's Blue Spruce, which, when rightly used, is one of the handsomest trees in the world. One of them at the focusing-point of the garden, or showing through a gap in other evergreens, enriches the landscape; but to plant four or five of them, or to make the planting entirely of them, is to overdo the thing and make them silly and tawdry.

The flowering trees are deciduous and may be used with equal propriety among evergreens or at the back of a shrubbery planting. The beauty of the Double-flowering Peaches is very intimate, and as they bloom very early in spring, the rather low trees should be placed so they can be closely observed without difficulty. The Flowering Plums are much like them and need the same treatment. The Japanese Weeping Cherry is used for an accent point, or where a very highly decorative effect is desired.

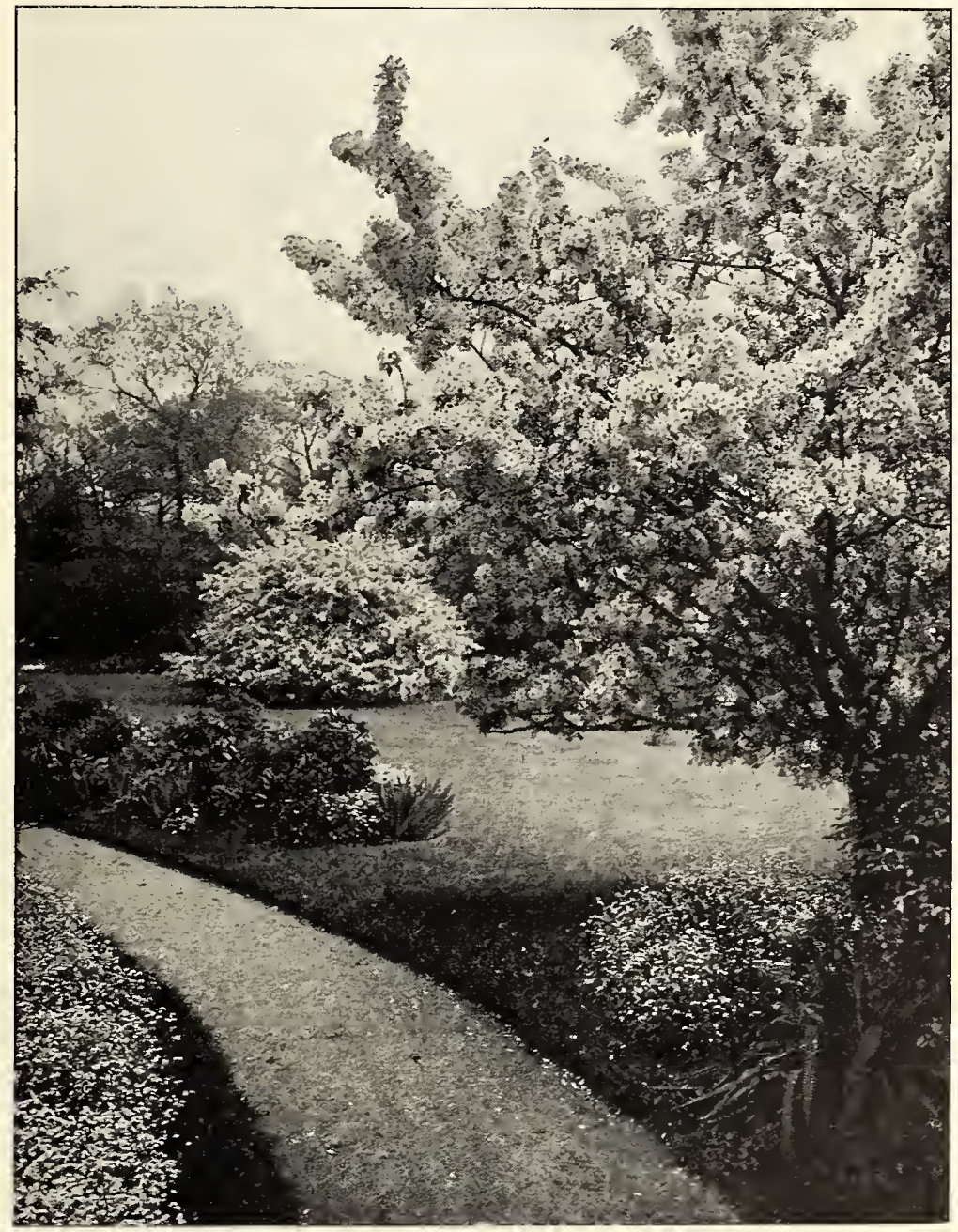

Flowering Crabapples are the most glorious of our flowering trees. Notice the profusion of bloom and the lovely symmetry of the one in the distance 


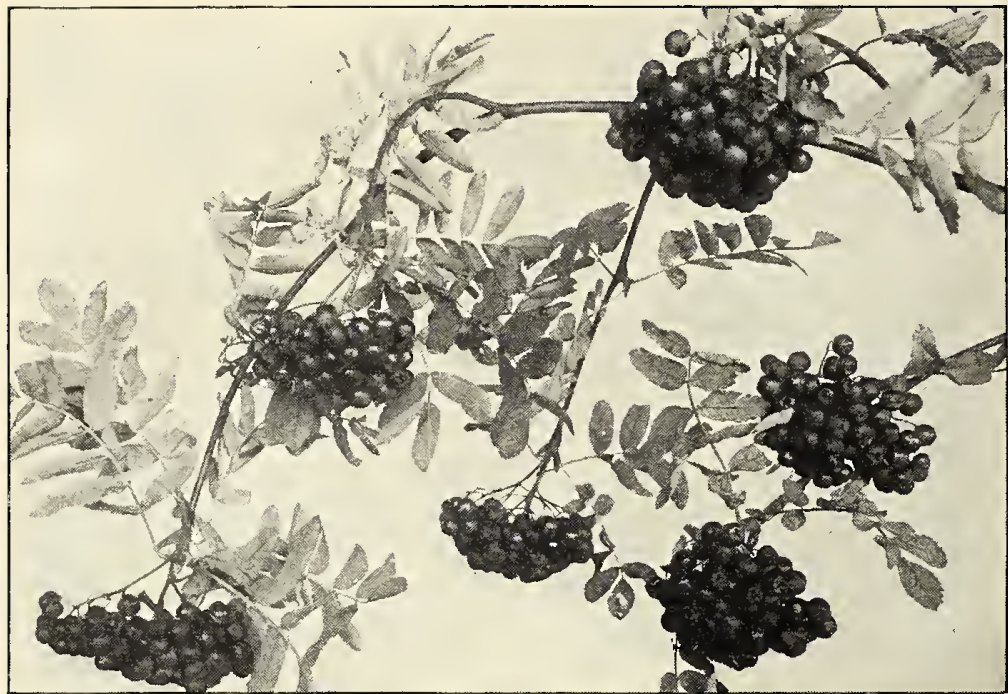

The Mountain-Ash is very decorative when loaded witb clusters of orange-red fruits like these in late summer and autumn

The Shadbush is a lovely tree for a hillside thicket, where its horizontal branches, covered with snowy bloom, show to best advantage above the tops of lower shrubs and trees. The Dogwoods are best in groups at the edge of a woods or with an evergreen background, and nothing is more lovely. They grow naturally on rich hillsides near the edge of forests, often in broad thickets, which they completely roof over with their flowers in spring. To walk beneath the intricate pattern their flowers make against the sky is to enjoy one of Nature's finest miracles. The Styrax is really a lily-of-the-valley grown to the stature of a tree. The way to enjoy it is to lie upon your back beneath it and look up. It needs little imagination to hear the tinkle of the waxen bells as the bees whiz among them, and one or two tinkles of that kind soon has the gardener's fancy roaming through a wonderland quite as romantic as Alice's.

\section{HAWTHORN, continued}

Thicket Hawthorn. Cratægus coccinea. A dense, shrubby tree, with clusters of large white flowers in spring and bright red fruits in autumn. 3 to 4 ft., $\$ 1.50$ each, $\$ 15$ for 12 .

Washington Thorn. C. cordata. Dense, thorny tree with glossy leaves and glowing red fruits, more vigorous than the foregoing. 3 to $4 \mathrm{ft}$., $\$ 1.50$ each, $\$ 15$ for 12 .

\section{Juniper • Juniperus}

Two very ornamental Junipers are described as Cedars among the Shade and Woodland Trees. The forms listed here are very decorative.

Golden Juniper. Juniperus communis aurea. Erect, columnar tree with rich golden yellow foliage. 18 in., $\$ 3$ each, $\$ 27.50$ for 12 .

IrISH JUNIPER. $J$. communis bibernica. Very slender, narrowly compact trees, never very large, useful for special formal designs and accent purposes. Foliage very dark green. 24 to $30 \mathrm{in}$., $\$ 3$ each.

\section{Maple • Acer}

Wier's Cutleaf Maple. Acer dasycarpum (wieri). A large, graceful tree with drooping branches and finely cut leaves. Highly ornamental as a specimen and is much planted. 8 to $10 \mathrm{ft}$., $\$ 3$ each.

\section{Mountain-Ash • Sorbus}

Mountain-Ash. Sorbus aucuparia. A small, graceful tree with striking foliage and clusters of bright red fruits 4 to $5 \mathrm{ft}$., $\$ 1.75$ each, $\$ 17.50$ for $12 ; 6$ to $8 \mathrm{ft}$., $\$ 2$ each, $\$ 20$ for 12 .

\section{Mulberry • Morus}

WeEping Mulberry. Morus alba (pendula). An ornamental, umbrella-shaped little tree at first, becoming a perfect fountain of foliage with age. 1-yr. head, $\$ 3$ each.

\section{Peach • Amygdalus}

Double-flowering Peach. Amygdalus persica. Very decorative Iittle trees covered with white, pink, or red double flowers before the leaves come out. Either color, 3 to $4 \mathrm{ft}$., $\$ 1$ each, $\$ 10$ for 12 .

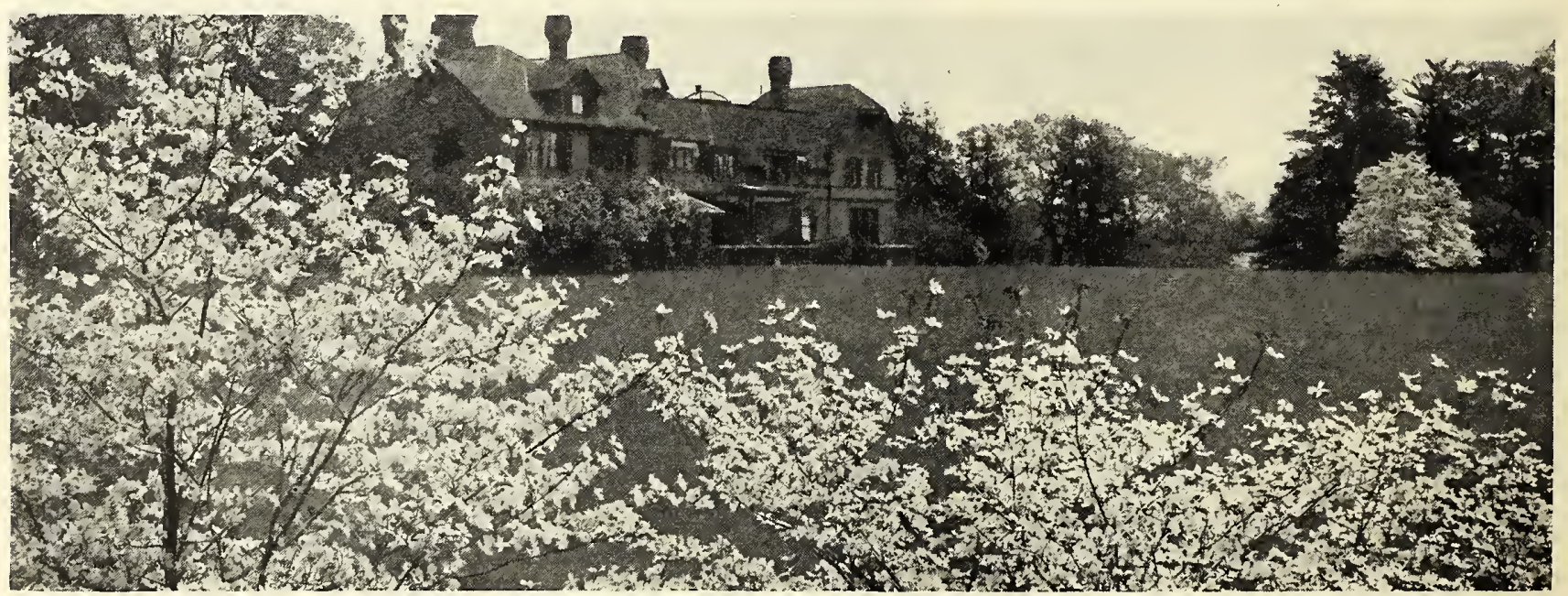

Notbing in the world looks so mucb like spring or gives such a feeling of the broad outdoors as a group of Doguoods or even a single specimen, if properly placed against a dark background of taller trees 


\section{O R N A M E T A L TREES}

\section{PIum • Prunus}

Flowering Plum. Prunus triloba. A small, spreading tree, covered with little, bright pink, very double flowers in spring. 2 to $3 \mathrm{ft}$., $75 \mathrm{cts}$. each, $\$ 7.50$ for 12 .

Purple-leaved Plum. $P$. cerasifera (pissardi). Slender tree with highly decorative, glossy, dark purple-crimson foliage. 3 to $4 \mathrm{ft}$, $\$ 1.50$ each.

\section{Poplar • Populus}

Lombardy Poplar. Populus nigra (italica). Useful for special columnar effects. Described in Shade and Woodland Trees. 6 to $8 \mathrm{ft}$., $\$ 1$ each, $\$ 10$ for 12 ; 8 to $10 \mathrm{ft}$., $\$ 1.50$ each, $\$ 15$ for 12

Shadbush • Amelanchier

Shadbush (Service Berry). Amelancbier canadensis. An irregular tree with white flowers in great sprays. 2 to $3 \mathrm{ft}$., $50 \mathrm{cts}$. each, $\$ 5$ for 12 .

\section{Spruce • Picea}

Koster's Blue Spruce. Picea pungens (Ko:teri). A very brilliant, steel-blue form of the Blue Spruce. Highly ornamental when sparingly used for very special effects and accents. 3 to $4 \mathrm{ft}$., $\$ 30$ each; 4 to $5 \mathrm{ft}$., $\$ 40$ each.

\section{Styrax $\cdot$ Styrax}

JAPANESE Strrax. Styrax japonica. Small trees with myriads of little, white, bell-like flowers, A lovely little tree. 3 to $4 \mathrm{ft}$., $\$ 1.50$ each.

\section{Umbrella Tree • Catalpa}

Umbrella Tree. Catalpa bignonioides nana. Often called Catalpa bungei. Stout trunk, with spreading, umbrella-like top. 5 to $6 \mathrm{ft}$., 1-yr. head, $\$ 2.50$ each; 5 to $6 \mathrm{ft}$., 2-yr. head, $\$ 3$ each.

\section{Yew - Taxus}

JAPANESE Yew. Taxus cuspidata. Gorgeous ornamental Evergreen with dark black-green foliage, tipped with yellow-green in spring and studded with rose-red berries in autumn. 15 to 18 in., $\$ 3.50$ each; 18 to 24 in., $\$ 4.50$ each.

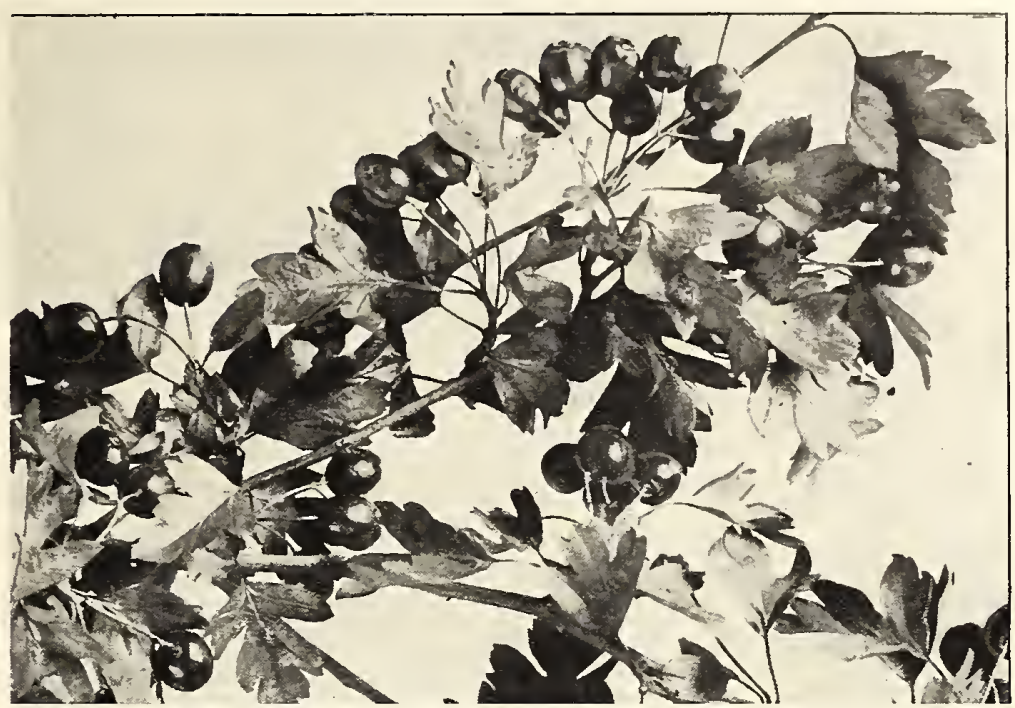

Fruits of the Hautborns make charming patterns on the brancbes and are one of their cbief cbarms. The birds enjoy them too

The Hawthorns are lovely things, with their drooping clusters of fragrant flowers; either when allowed to make impassable thickets, lovely tall hedges, or mingled with shorter shrubbery. They are good companions for the Flowering Crabs, which are the finest flowering trees we have in this country.

We have frequently remarked how much more useful and how much more beautiful the native and introduced Flowering Crabs are than the highly praised and advertised Japanese Cherries. They have equal floriferousness, a Ionger season, a range of color the Cherries never knew, a fragrance as rich as the lilacs, and in the autumn a glory of sparkling fruits.

The Thorns are also to be noted for their brilliant haws, the Dogwoods have exceedingly brilliant scarlet berries, and the gorgeous bunches of orange-red fruits that cling upon the MountainAsh more than justify its existence.

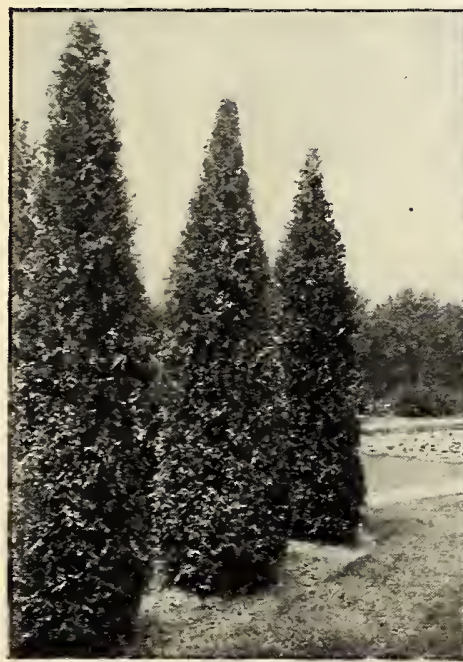

The erect formality of the Arborvitas

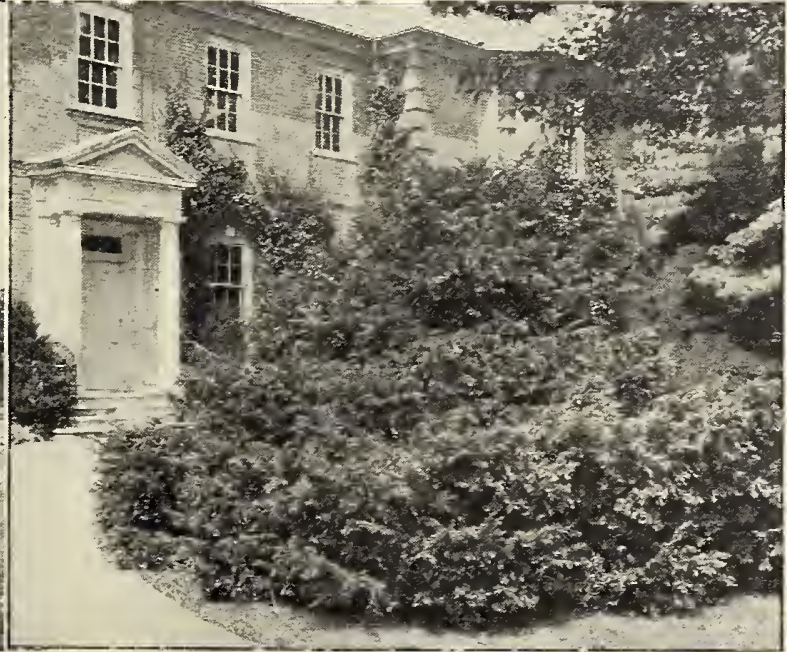

Note the beautiful mound of foliage made by tbis soft, dark featbery Yew

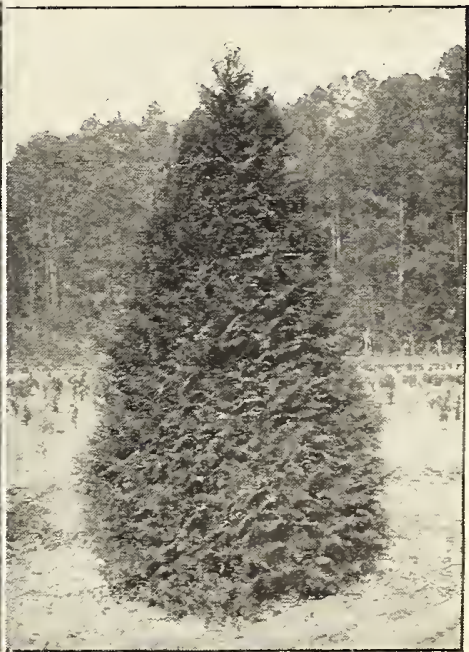

Notice the soft texture of this bardv Cypress 


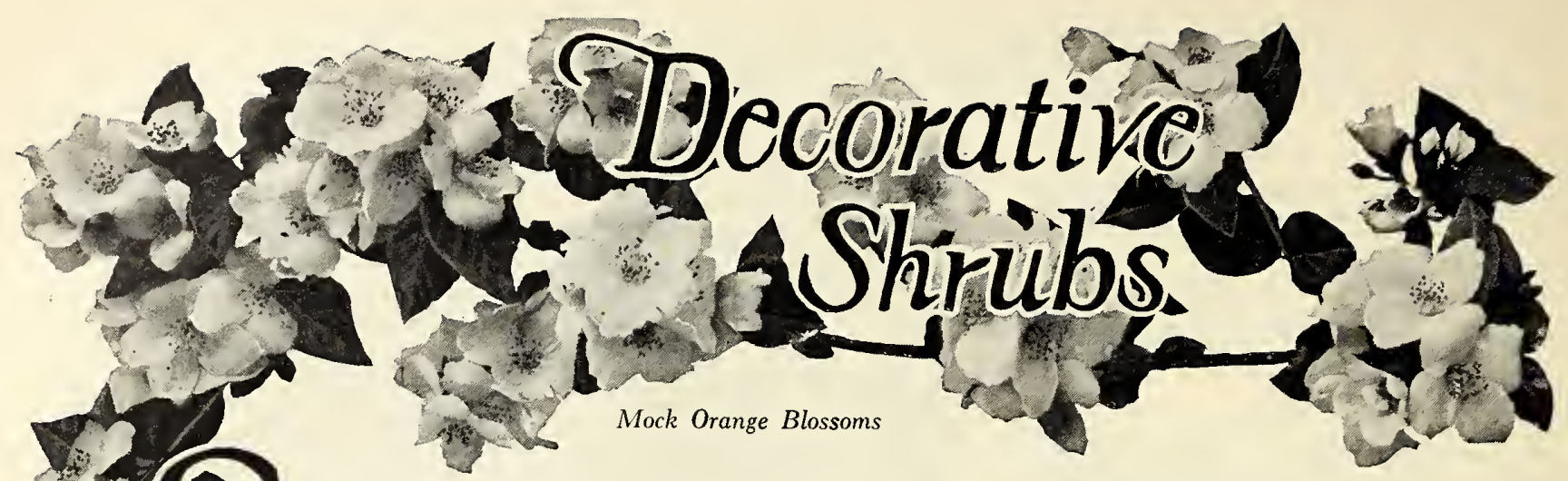

HRUBS are almost as much permanent fixtures of a property as the house and other buildings. Shade and Woodland Trees are used to establish the setting for the buildings and to make broad landscape pictures; and the Ornamental Trees punctuate the planting with points of distinct form or bright spots of color. But Shrubs have a more intimate purpose.

Rightly used, they join the lines of the buildings to the lawn, blending and fitting them to the ground; and they bring the larger trees into proper relationship with the grass and flowers that are used in the borders. Used alone, they serve as specimen accents or as a natural border to the grounds.

Among the Shrubs, we include such woody plants as grow from one or two feet to fifteen feet high or more. It is difficult to draw a definite line between large Shrubs and the smaller trees. Some of the Ornamental Trees mentioned in the previous chapters might well be included in this section; and, with equal propriety, such things as Redbud, Halesia, and some of the Lilacs described here could have been included among the Ornamental Trees.

Here we have also included the group of small or dwarf Conifers commonly called Evergreens, which are so valuable for planting along the base of walls or foundations; and those Flowering Shrubs usually referred to as Broad-leaved Evergreens. By stature and use they belong in this section, and no Shrub planting is complete or representative without them.

\section{The Common Shrubs}

A great many of the most cherished garden memories have to deal with the Shrubs of olden times. Who has not crushed in his pocket the queer, starry, brown-red flowers of the old Sweet Shrub and carried them around until they have dried to powder, but still carrying the delicious odor which gave it the common names, Strawberry Shrub and Carolina Allspice? In some parts of the country it was merely called the Shrub. The Sweet Shrub had a place in every old garden, often snuggled into a fence-corner or half hidden by the overhanging Lilacs. It grows well almost everywhere. A peculiarity is that not all plants are equally fragrant, and there is no way of telling which, and some years they are more fragrant than others.

For the Lilacs, too, there is a host of treasured memories, and no garden is really settled and home-like until a sturdy old Lilac is established there. The common Purple (Syringa vulgaris) is still the best loved of all, although many have a fondness for the white one. They grow quite tall, in case you have forgotten, and should be placed well to the back, or in a corner, if the grounds are
The Sbrubs mentioned in the text, as well as many otber interesting species, are offered in this column. For varieties not listed consult tbe Index.

\section{Acanthopanax - Acanthopanax}

Acanthopanax. Acantbopanax pentapbyllum. An arching shrub, 5 to 10 feet high, with fine glossy leaves. 2 to $3 \mathrm{ft}$., $50 \mathrm{cts}$. each, $\$ 5$ for 12 .

\section{Almond • Prunus}

Flowering Almond. Prunus glandulosa. Often called Amygdalus cbinensis. Bushy shrubs, about 4 feet high with double pink flowers in early spring. 2 to $3 \mathrm{ft}$., $\$ 1$ each, $\$ 10$ for 12 .

Writte-Flowering Almond. The same, with white flowers. 2 to $3 \mathrm{ft}$., $\$ 1$ each, $\$ 10$ for 12 .

\section{Althea - Hibiscus}

Althea. Hibiscus syriacus. Tall, tree-like shrubs, excellent for large borders, specimens, and even street planting. Bloom in midsummer and late. Withstand considerable shade. Flowers of various colors-Double Red, Double Blue, Double Pink, Double White, and Single White. Any color, 2 to $3 \mathrm{ft}$., 60 cts. each, $\$ 6$ for 12 .

\section{Arborvitæ - Thuja}

Booth's. Thuja occidentalis. A Iow, round evergreen about 2 feet high, like a bright green cushion. Fine for window-boxes or foundation planting. 18 in., $\$ 2$ each.

Globe Arborvite. T. occidentalis (globosa). Very dwarf, perfectly round, of great neatness and beauty for formal effects. 15 to 18 in., $\$ 3$ each; 18 to 24 in., \$4 each.

Hovey's. T. occidentalis. Similar to above. Dwarf, very dense, bright green, rather oval in shape, suitable for same uses. 18 to 24 in., $\$ 3$ each.

Litrte Gem. $T$. occidentalis. Exceedingly dwarf, warm, dark green, usually broader than high. Fine for rockeries or step-planting. 12 to 15 in., $\$ 3.50$ each. 


\section{Azalea • Azalea}

A very handsome group of plants, some deciduous and some evergreen, closely allied to the rhododendrons and requiring the same sour-soil treatment.

Amana. Azalea amana. An evergreen species covered in spring with very brilliant purple-red flowers. 12 to 18 in., $\$ 3$ each, $\$ 27.50$ for 12 .

Chinese Azalea. A. mollis. Not evergreen, and the flowers orange-red to scarlet. Grows about 4 feet high. Very showy. 15 to 18 in., $\$ 3$ each.

Flame Azalea. A. calendulacea. A gorgeous native with flowers varying from lemon-yellow to bright orange on different plants. 18 to 24 in., $\$ 2.50$ each, $\$ 25$ for 12 .

Hinodegiri. A. binodegiri. A bright red form of Amoena. Practically evergreen, and very brilliant when in flower. 12 to $18 \mathrm{in}$., $\$ 3$ each, $\$ 27.50$ for 12.

Piedmont Azalea. A. canescens. A rather downy plant with pale pink and white, very fragrant flowers, much like the Pinxter Flower, 1 to 3 feet high. 18 to 24 in., \$2.50 each, \$25 for 12.

Pink Shell Azalea. A. vaseyi. Rather tall. Flowers pale rose, spotted with orange and brown. 18 to 24 in., $\$ 2.50$ each, $\$ 25$ for 12 .

Pinxter Flower. A. nudiflora. Covered with light rosy pink flowers before the leaves come out. 18 to 24 in., $\$ 2.50$ each, \$25 for 12.

Swamp Honeysuckle. A. viscosa. A moistureloving species which blooms after the leaves come out. Flowers white, tinged pink, and intensely fragrant. 18 to 24 in., $\$ 2.50$ each, $\$ 25$ for 12 .

Sweet Azalea. A. arborescens. Very tall, up to 20 feet. Flowers very fragrant, white, tinged pink. 18 to 24 in., $\$ 2.50$ each, $\$ 25$ for 12 .

\section{Barberry - Berberis}

Neubert's. Berberis neuberti. Handsome shrub, with leathery, almost evergreen, leaves. 18 to 24 in., \$1 each, \$10 for 12 .

Red-leaved Barberry. B. thunbergi. A new, bright red-leaved form of the Japanese Barberry. Very fine for special color effects. 2-yr. -old, \$1 each, $\$ 10$ for 12 . small. On large places a long border of Lilacs is superb. The one in the Arnold Arboretum at Boston is visited by thousands every year. Being closely related to the Privet, the Lilac foliage is just as tough and resistant to unfavorable conditions, so that a planting of Lilacs is always neat and attractive. Besides the common white and purple sorts, there are the lacy Persian varieties, white and purple, with large, feathery ćlusters of flowers; and the big Tree Lilac (S. japonica), bearing yellow-white flowers in bunches a foot long. It is really a tree, sometimes 30 feet high. The Late Lilac (S. villosa) is also worth having because it blooms long after the others have finished. Its flowers are pinkish white, but the odor is not at all like that of the common variety.

It puzzles many people that the botanical name Syringa, which belongs to the Lilacs, should also be used as a common name for the Mock Oranges. The reason is that the Mock Orange family used to be called Syringa, but the botanists decided that name properly belonged to the Lilacs and that the Mock Oranges should be called Pbiladelphus. The ways of botanists are very confusing to laymen, but they have good reasons, no doubt, for what they do. Fortunately, the old name, Sweet Syringa, is dying out, and Mock Orange is taking its place; besides, so many fine new varieties are coming into the gardens now that have special, varietal names of their own. Of course, the fragrant old Coronarius, or Mock Orange, will always be wanted, but anyone who has seen the new hybrid varieties will be astonished and thrilled at the wide range of habit, size, and profusion of flowers and, most of all, by the wholly new series of perfumes which they afford. No two of them are anything alike, and in a good collection of new Mock Oranges, one can have a most interesting time going from plant to plant testing the fragrance and comparing it with that of other flowers.

In discussing fragrance we must mention the lovely little Garland Flower which delights in a sunny bank with sour, peaty soil,

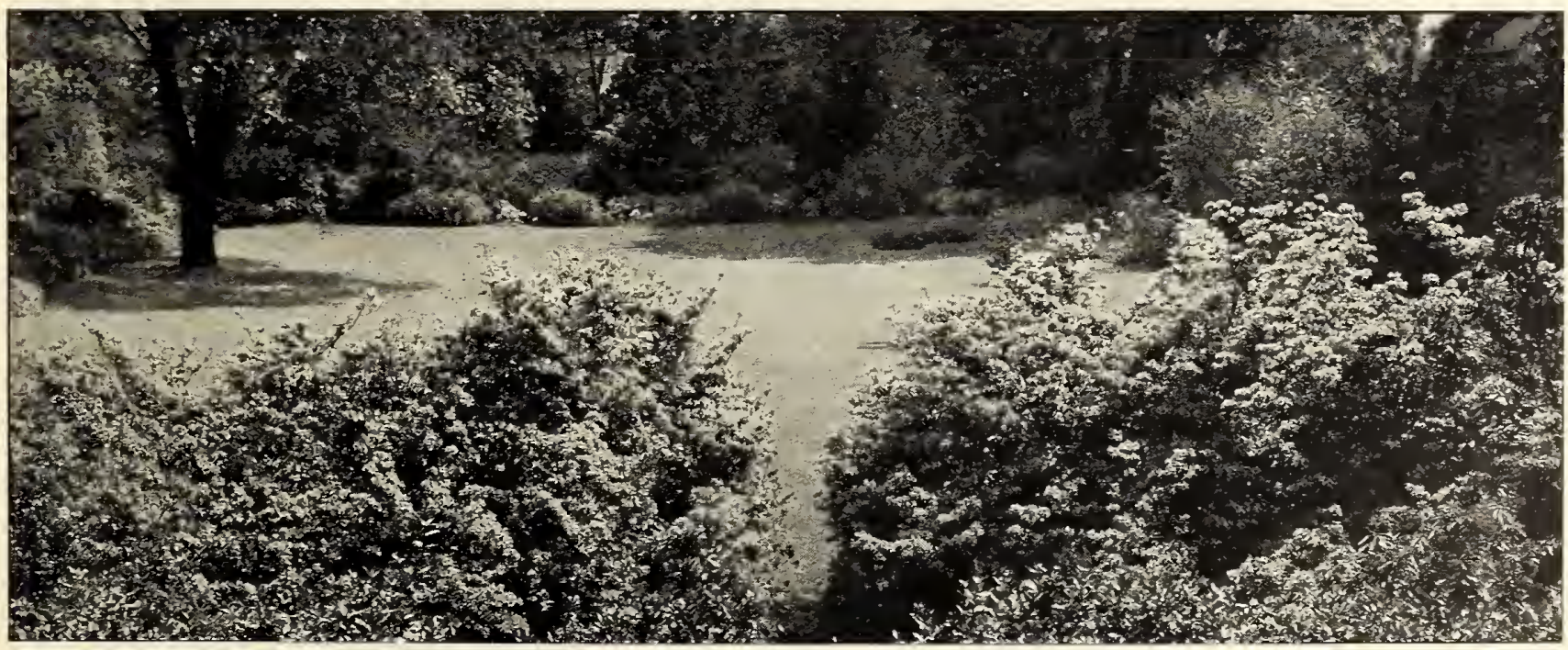

A spread of lawn beautifully framed by trees and sbrubs. The great flowering sbrubs in the foreground are Azaleas.

Tbis gardenis in Massacbusetts 


\section{ELLIOTT NURSERY COMPANY + PITTSBURGH, PA.}

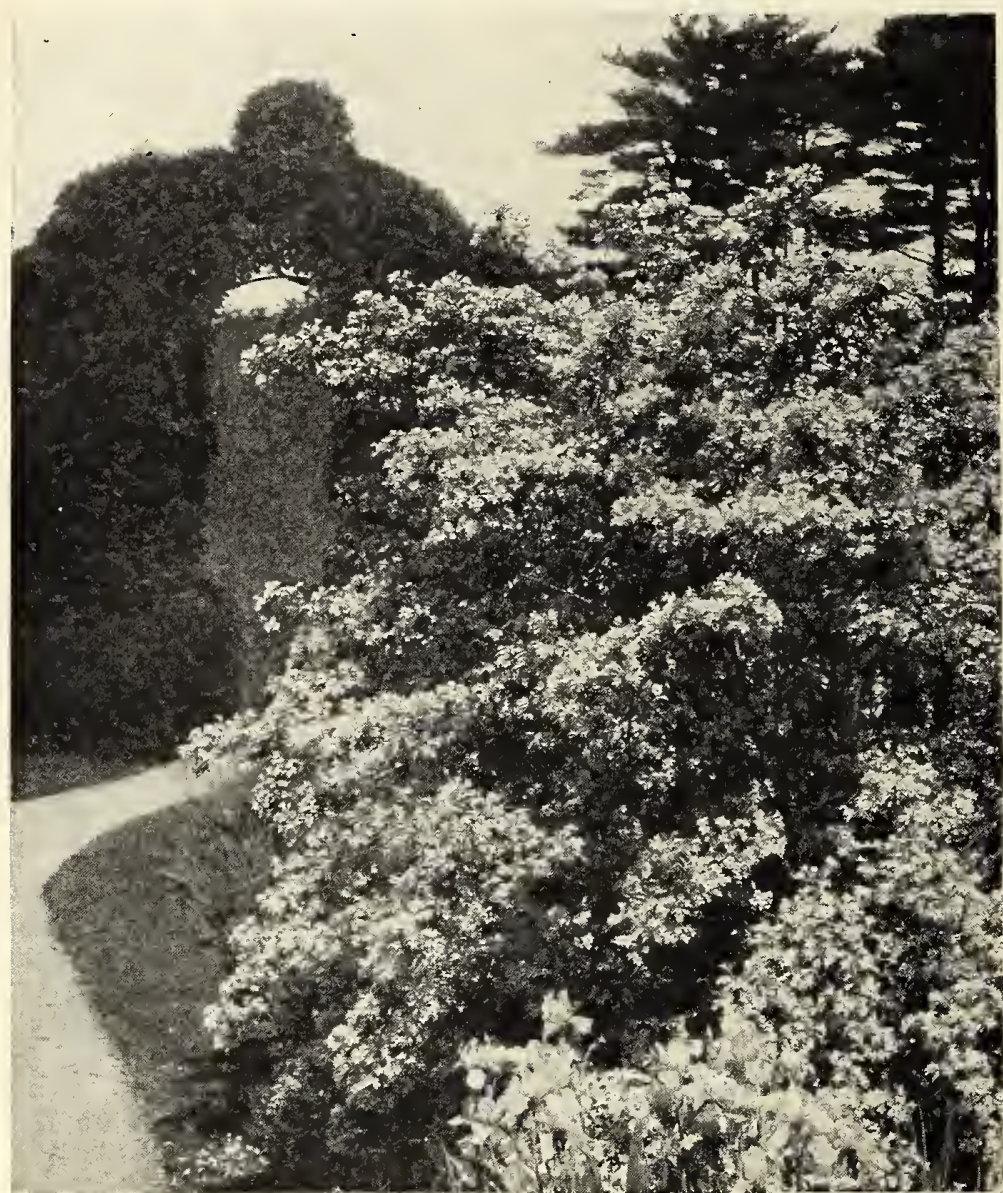

Beauty Busb (Kolkwitzia amabilis) in full bloom is a smotber of delicate pink and wbite bells. A very lovely shrub

where it will produce, several times a season, sheets of delicious pink flowers with an incomparable perfume. The marvelously scented Viburnum carlesi is worth having also for fragrance alone, and so are certain of the Honeysuckles. The common Honeysuckle, so noted for its fragrance, is a vine.

The old-time Clove Bush, or Golden Currant, is one of the most favored of all by the garden gods of fragrance. The large, straggling shrub is covered with clusters of yellow flowers of clove-Iike shape and odor very early in the spring, so that the whole ncighborhood is bathed in a most delicious perfume. It is highly doubtful if any real garden-lover could exist at all without a Clove Bush on his premises; it is one of the essentials.

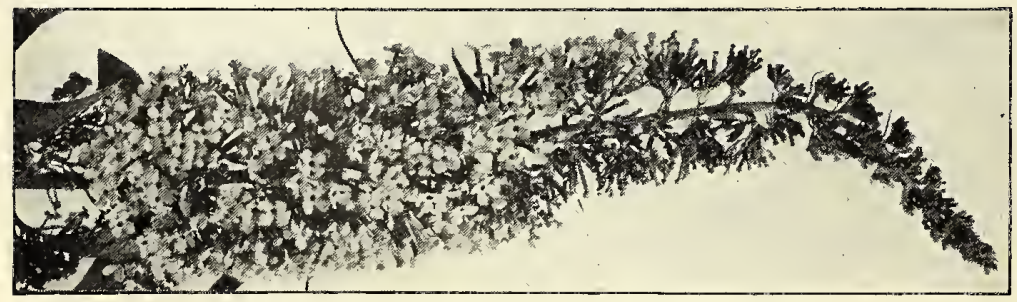

Flowers of the Butterfly Busb (Buddleia davidi)
Bayberry - Myrica

COMMON BAyaerRy. Myrica carolinensis. The picturesque seashore shrub from which Bayberry candles are made. Its berries are small, silvery white along the twigs, and very aromatic. This plant is sometimes erroneously listed as $M$. cerifera. 18 in., 60 cts. each, $\$ 6$ for 12 .

\section{Beauty Bush · Kolkwitzia}

Beauty Bush. Kolkwitzia amabilis. Fine, large, graceful plant, covered with tiny trumpet-like flowers of bright shell-pink. One of the outstanding introductions of recent years. 18 to 24 in., $\$ 2.50$ each.

\section{Blue Spirea - Caryopteris}

Blue Spirea. Catyopteris incana. A low-growing, erect shrub with grayish foliage, covered in autumn with small woolly clusters of hazy blue flowers. One of the very few blue autumnflowering plants; very useful for filling in places and as an undershrub. $50 \mathrm{cts}$. each, $\$ 5$ for 12 .

\section{Box - Buxus}

DWarF Box. Buxus semperitrens suffruticosa. The famous dwarf, evergreen Box used for edging paths and finishing beds. Practically everlasting and always beautiful. 5 to 7 in., $\$ 4.50$ for $12, \$ 30$ per 100 .

\section{Buckthorn - Rhamnus}

Common Bucrsthorn. Rbamnus cathartica. A glossy-leaved, thorny hedge plant about 10 feet high. Very hardy. Foliage bright yellow in autumn. 2 to $3 \mathrm{ft}$. $50 \mathrm{cts}$. each, $\$ 5$ for $12 ; 3$ to $4 \mathrm{ft}$., 60 cts. each, $\$ 6$ for 12

\section{Buddleia • Buddleia}

Butterfly Bush. Buddleia davidi. Long, grayish foliage and tassel-like sprays of bright purple flowers with orange eyes. Often freezes to the ground in winter but restores itself and bloorns the same season. $50 \mathrm{cts}$. each, $\$ 5$ for 12 .

\section{Button Bush - Cephalanthus}

Button Bush. Cepbalanthus occidentalis. A fine, glossy, waterside shrub, 4 to 10 feet high, bearing balls of cream-white flowers in July 2 to $3 \mathrm{ft}$. 50 cts. each, $\$ 5$ for $12 ; 3$ to $4 \mathrm{ft}$., 60 cts. each, $\$ 6$ for 12 .

\section{Callicarpa - Callicarpa}

BeAUTY BERRY. Callicarpa purpurea. Tough, vigorous shrubs about 4 feet high, bearing clusters of rich violet-purple berries along the twigs in autumn and winter. Very unusual color in berries and a very beautiful plant. 2 to $3 \mathrm{ft}$., 50 cts. each, $\$ 5$ for 12 .

\section{Caragana - Caragana}

PEA TREe. Caragana arborescens. Strong shrub or small tree sometimes attaining 15 to 20 feet. Flowers pea-like, yellow, in small clusters, produced in late spring. $50 \mathrm{cts}$. each, $\$ 5$ for 12 .

\section{Ceanothus - Ceanothus}

Jersey Tea. Ceanotbus americana. Dwarf, bushy plants about 2 feet high, covered with clusters of little white flowers in late summer. Excellent for edging taller plants, 18 in., 50 cts. each, $\$ 5$ for 12 . 


\section{Chokeberry • Aronia}

Red Chokeberry. Aronia arbutifolia. Bushy shrub over 5 feet high, with glossy leaves and clusters of white flowers followed by persistent red berries. Grows well in dry, shady places where other things perish. 2 to $3 \mathrm{ft}$., $60 \mathrm{cts}$. each, $\$ 6$ for 12 .

\section{Currant • Ribes}

Golden Currant. Ribes aureum. Often called the "Clove Bush" because of the delicious odor of its yellow flowers. Quite large, up to 8 feet; blooms very early. 2 to $3 \mathrm{ft}$., $50 \mathrm{cts}$. each, $\$ 5$ for $12 ; 3$ to $4 \mathrm{ft}$., 60 cts. each, $\$ 6$ for 12 .

Mountain Currant. $R$. alpinum. A desirable shrub of dense habit, sometimes 8 feet tall. Close, bright foliage. Covered with brilliant red berries in summer and autumn. Good for shady places and for hedges. 18 to 24 in., $60 \mathrm{cts}$. each, $\$ 6$ for 12 .

\section{Daphne - Daphne}

Garland Flower. Dapbne cneorum. A smallleaved, evergreen shrub less than 2 feet high, covered two or three times each season with clusters of intensely fragrant rose-pink flowers. Excellent on rocks or in sour-soil situations in full sun. $\$ 1.50$ each.

\section{Deutzia • Deutzia}

Gracicrs. Deutzia gracilis. A s'ender, willowy little shrub with dense clusters of pure white flowers. Fine for edging larger shrubs. 15 to 18 in., 60 cts. each, $\$ 6$ for 12 .

Gracilis CARMINEA. D. gracilis. The same as above but flowers stained dark rose-pink. 18 to 24 in., 75 cts. each, $\$ 7.50$ for 12 .

Gracilis rosea. D. gracilis. Like $D$. gracilis but tinted light pink. 18 to 24 in., 75 cts. each, $\$ 7.50$ for 12 .

Lemoine's. D. lemoinei. A slender, dwarf shrub with dense clusters of creamy white flowers. One of the very best. 2 to $3 \mathrm{ft}$., $60 \mathrm{cts}$. each, $\$ 6$ for 12 .

Magnifica. D. magnifica. Tall, straggling shrub with panicles of double white flowers. 2 to $3 \mathrm{ft}$., 75 cts. each, $\$ 7.50$ for 12 .

Pride of Rochester. D. scabra. Tall. Very much like Snowflake except that the flowers are tinged with rose-pink. The best known of the family. 2 to $3 \mathrm{ft}$., $50 \mathrm{cts}$. each, $\$ 5$ for $12 ; 3$ to $4 \mathrm{ft}$., $60 \mathrm{cts}$. each, $\$ 6$ for 12 .

SNowflake. D. scabra (candidissima). Erect to 8 feet; showy clusters of double white flowers. 2 to $3 \mathrm{ft}$. $50 \mathrm{cts}$. each, $\$ 5$ for $12 ; 3$ to $4 \mathrm{ft}$., 60 cts. each, $\$ 6$ for 12 .

\section{Dogwood · Cornus}

Blood-Twig Dogwood. Cornus sanguinea. TaII shrub to 12 feet, with dark crimson twigs, sometimes purple. 2 to $3 \mathrm{ft}$., $50 \mathrm{cts}$. each, $\$ 5$ for 12 3 to $4 \mathrm{ft}$., 60 cts. each, $\$ 6$ for 12 .

Coral Dogwood. C. alba (sibirica). Vigorous wiry bush, 10 feet high, with brilliant coral-red twigs, very showy in winter. The flowers are whitish, in flat clusters but of secondary importance. 2 to $3 \mathrm{ft}$., $50 \mathrm{cts}$. each, $\$ 5$ for $12 ; 3$ to $4 \mathrm{ft}$., 60 cts. each, $\$ 6$ for 12 .

Flowering Dogwood. See Ornamental Trees.

Golden Twig. C. stolonifera (lutea). A similar, erect-stemmed, wiry bush 8 feet high, with bright yellow branches, brilliant in the winter landscape 2 to $3 \mathrm{ft}$., $50 \mathrm{cts}$. each, $\$ 5$ for $12 ; 3$ to $4 \mathrm{ft}$., $60 \mathrm{cts}$. each, $\$ 6$ for 12 .

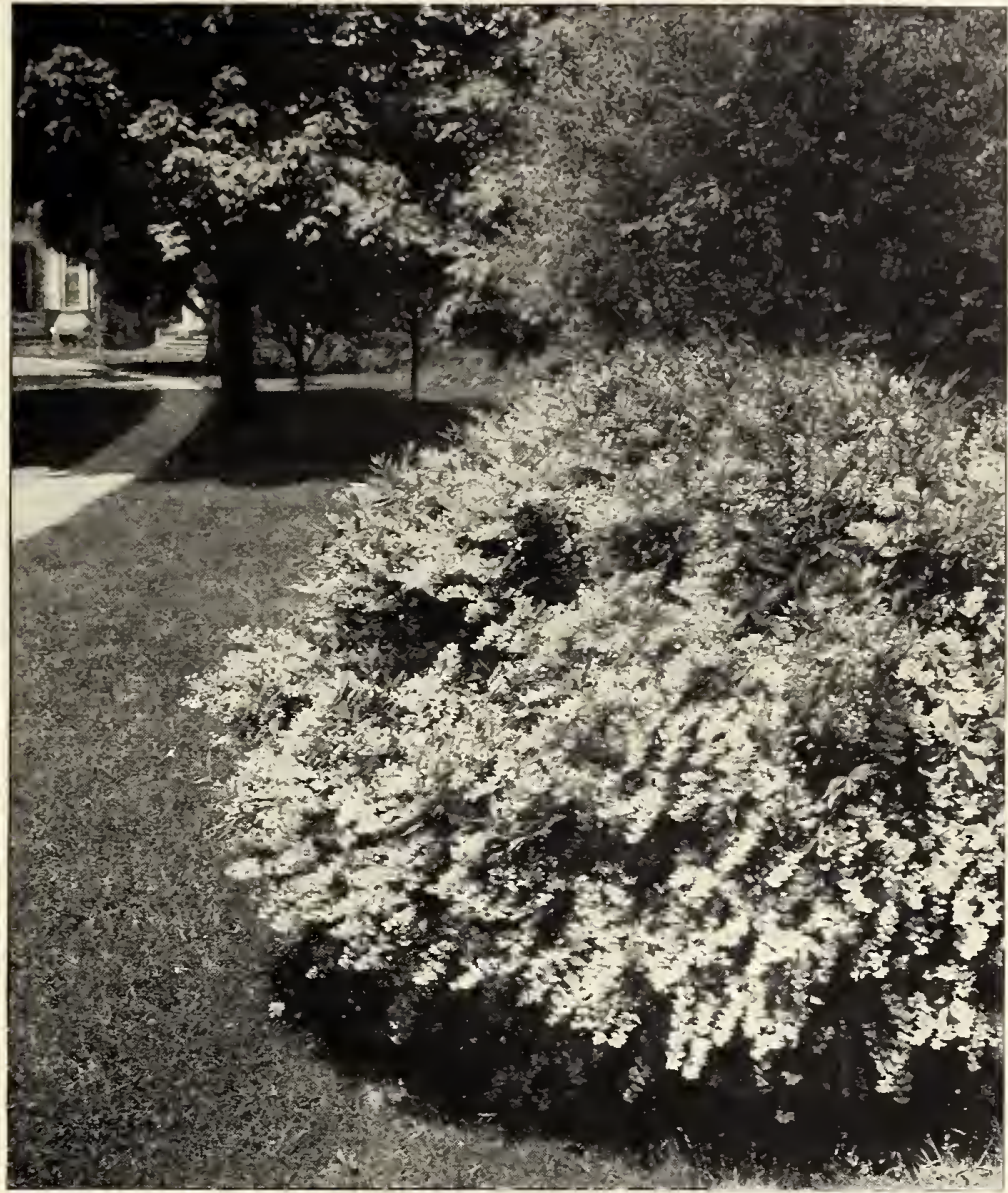

Deutzia gracilis is very graceful at the edge of a planting of larger sbrubs

The Altheas are familiar shrubs, almost small trees at times, which have the merit of blooming late in the summer, long after most shrubs have subsided into foliage. Everyone is familiar with their fluted, ruffled flowers, like hollyhock blooms, produced in such abundance that the leaves are hidden. They are good utility shrubs, withstanding severe conditions which would discourage almost anything else.

Hydrangeas are well known, and one of them, Peegee, known aImost too well. Its immense heads of flowers, which would more than cover this page, are a glorious sight, but so many people have it, and there are so many finer things, that small gardens can afford to pass it up for something better. The Oak-leaf Hydrangea, for

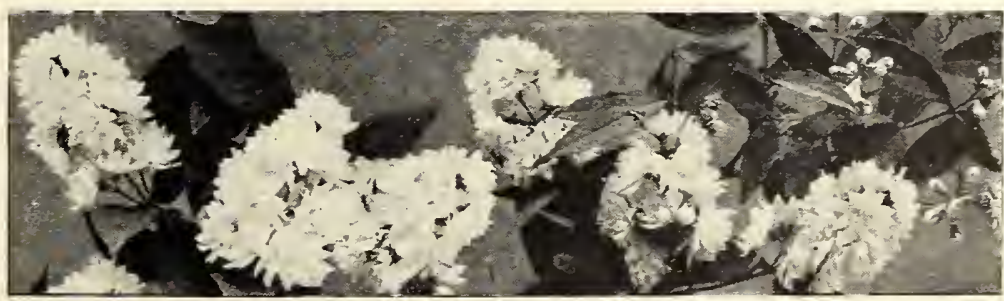

Flowers of Deutzia, Pride of Rocbester 


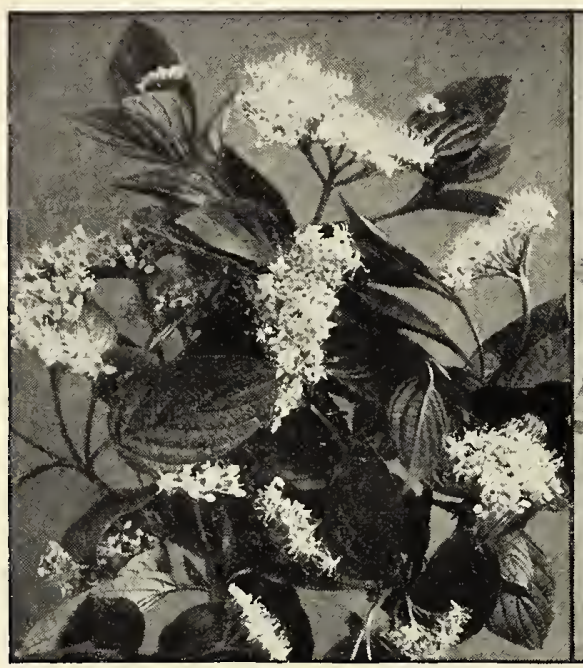

Spætb's Dogwood (Cornus alba)

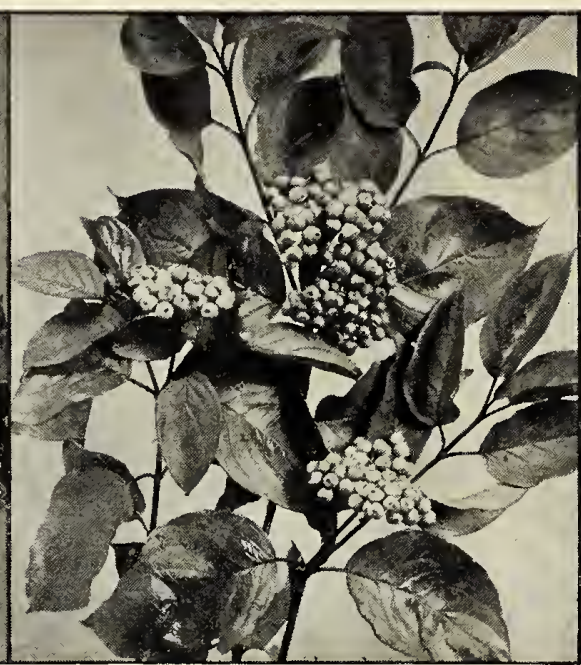

Silky Dogwood (Cornus amomum)

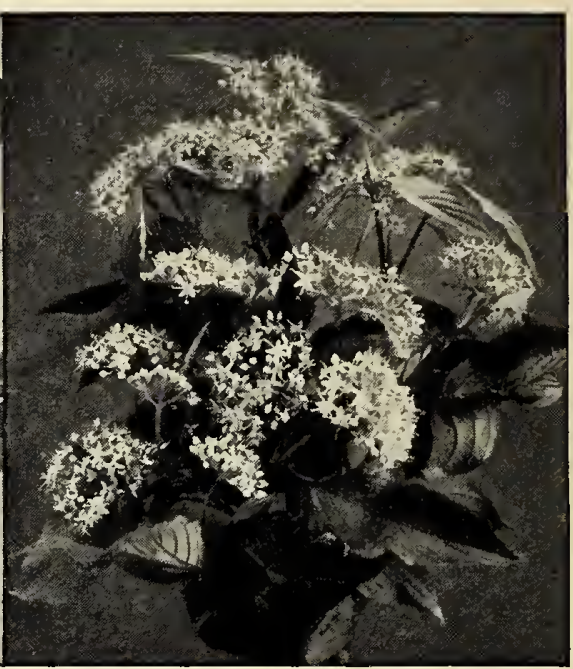

Red Osier (Cornus stolonifera) instance, with its gigantic, oak-like foliage, and very curious, shredded, hanging bark, is one of the most interesting plants in the world. Its flower-heads are Iarge enough to satisfy the most Gargantuan taste. The well-known Hills of Snow (H. arborescens grandiflora) is a fine thing for growing in the shade. Its heads of flowers are much more delicate than those of any of the other varieties, most of which are more or less coarse.

The Snowball Bush is just as well known as the Lilac. Always it provides great bouquets of bloom for Memorial Day, often mixed with the big, mournful flowers of the old-fashioned German Iris, or Blue Flag. It comes with the early Peonies and the oldfashioned yellow Roses right at the frrst blush of summer, drooping its spotless balls of bloom all over the giant, leafy bush. There are really two varieties of the true Snowball: Viburnum opulus sterile is the old-fashioned one with which most of us are familiar; $V$. tomentosum plicatum is the Japanese variety, very much the same except that the flower-clusters are a trifle more compact and come a little later. Its dark green leaves are very deeply pleated or creased, and lovely in themselves. Among the other members of this family, we have already mentioned the fragrance of the delicious $V$. carlesi; but by far the most beautiful of all Viburnums -and one is almost tempted to say of all shrubs-is the single form of the Japanese SnowbalI ( $V$. tomentosum). Its long, horizontal branches are covered in May with the most intricate mosaic of lacelike flowers, reminiscent of the old-fashioned embroidery work that used to adorn the broad white collars of little boys who suffered in Lord Fauntleroy suits. The flowers come in two rows on each branch, each bloom 4 inches across, with an open-work center and a ring of fine, crisp white florets on the outside edge. A broad spray of this Viburnum is about the most gorgeous flower display that the eye can look upon.

Among useful large shrubs, the Weigelas are important. They grow five to seven feet high, with very sturdy stems, and in late spring cover themselves with tubular or trumpet-shaped flowers of great beauty. The most appealing is the white variety, Candida, with exquisitely lovely, waxy white flowers. For variety's sake,
Gray Dogwood. Cornus paniculata. Round-headed shrub with many creamy white flowers, followed by white berries on bright red stems. The leaves turn dark red in autumn. 2 to $3 \mathrm{ft}$., $50 \mathrm{cts}$. each, $\$ 5$ for $12 ; 3$ to $4 \mathrm{ft}$., $60 \mathrm{cts}$. each, $\$ 6$ for 12 .

Red Osier. C. stolonifera. Slender, wiry, but bushy shrub with smooth, glossy, red stems, very effective in the winter landscape. Bluish white fruits in autumn. 2 to $3 \mathrm{ft}$., $50 \mathrm{cts}$. each, $\$ 5$ for $12 ; 3$ to $4 \mathrm{ft}$., $60 \mathrm{cts}$. each, $\$ 6$ for 12 .

Silky Dogwood. C. amomum. Vigorous shrub to 10 feet, with dark purple branches, white flowers, and bright blue fruits. 2 to $3 \mathrm{ft}$., $50 \mathrm{cts}$. each, $\$ 5$ for $12 ; 3$ to $4 \mathrm{ft}$., $60 \mathrm{cts}$. each, $\$ 6$ for 12 .

Spaeth's. C. alba. Somewhat like the Coral Dogwood, with broad, showy green leaves, deeply edged with golden yellow. 18 to 24 in., 60 cts. each, $\$ 6$ for 12 .

WeEping Osier. C. stolonifera (pendula). An arching form of the Red Osier and extremely decorative. 18 to 24 in., 50 cts. each, $\$ 5$ for 12 .

\section{Elder • Sambucus}

American. Sambucus canadensis. A common roadside or fence-row shrub with pithy stems, broad leaves, and immense, flat heads of lovely, fragrant, creamy white flowers followed by edible black berries fit for pies, jellies, and wine. 2 to $3 \mathrm{ft}$., $50 \mathrm{cts}$. each, $\$ 5$ for 12 .

European Red. S. racemosa. A fine companion for the Golden variety, with showy red fruits while the other is blooming. Flowers are white. 2 to $3 \mathrm{ft}$., $60 \mathrm{cts}$. each, $\$ 6$ for 12 .

Golden European. S. nigra (aurea). A decorative foliage shrub for bright yellow effects. 2 to $3 \mathrm{ft}$., 60 cts. each, $\$ 6$ for 12 .

\section{False Indigo - Amorpha}

Indigo Bush. Amorpba fruticosa. Very ornamental in dry, sunny places. Feathery foliage and flowerspikes of remarkable purple-blue. Grows 5 to 10 feet high. 2 to $3 \mathrm{ft}$., 50 cts. each, $\$ 5$ for 12 .

\section{Fatsia - Fatsia}

Angelica Tree. Fatsia japonica. A small tree of tropical effect, with large leaves and clusters of small whitish flowers. 3 to $4 \mathrm{ft}$., $60 \mathrm{cts}$. each, $\$ 6$ for $12 ; 4$ to $5 \mathrm{ft}$., $75 \mathrm{cts}$. each, $\$ 7.50$ for 12 . 


\section{E C O R A T IVE S H R U B S}

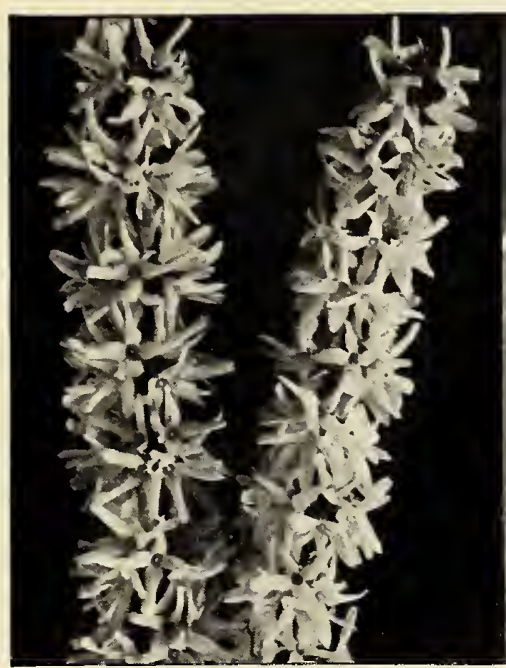

Flowers of Forsytbia spectabilis

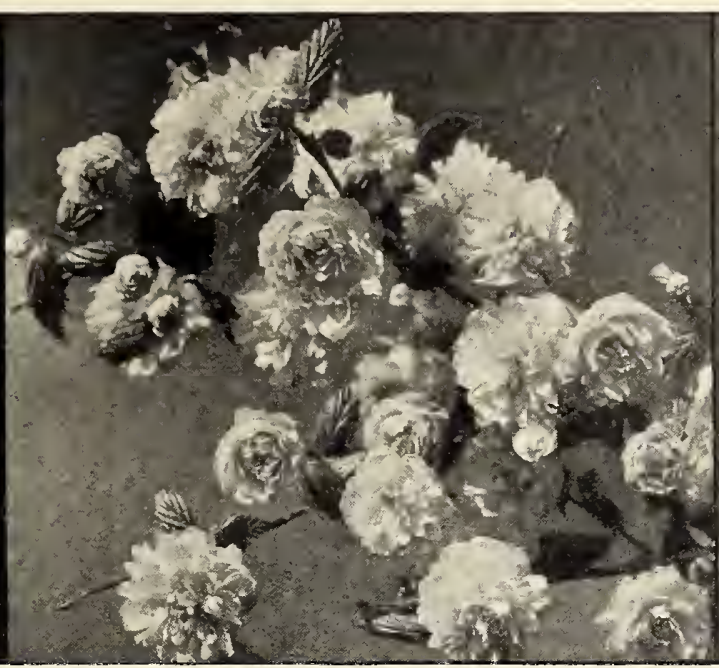

The Double Kerria, like balls of gold

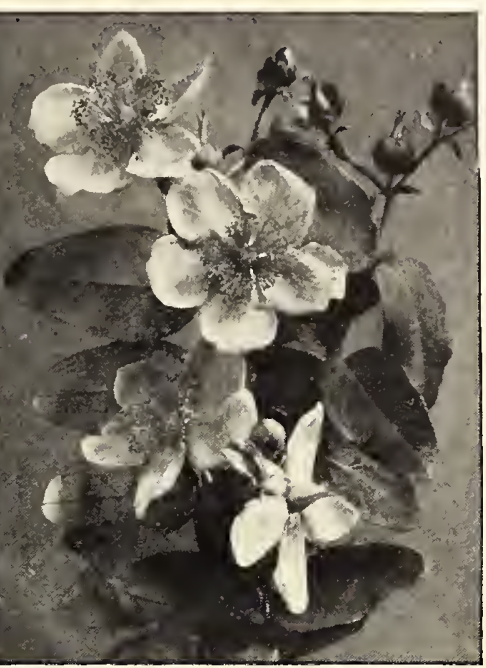

The Gold Flower, Hypericum moserianum
Firethorn - Pyracantha

LAlande's. Pyracantba coccinea. An extremely handsome evergreen shrub, very erect and bushy, often reaching 10 feet, with shining, hard, green leaves and brilliant bunches of glittering orangered fruits. $\$ 1$ each, $\$ 10$ for 12 .

\section{Forsythia - Forsythia}

Border Forsythia. Forsytbia intermedia. Erect, arching bush to 8 feet, covered in spring with bright yellow bells. 2 to $3 \mathrm{ft}$., $50 \mathrm{cts}$. each, $\$ 5$ for $12 ; 3$ to $4 \mathrm{ft}$., $60 \mathrm{cts}$. each, $\$ 6$ for 12 .

ForTunE's. F. suspensa fortunei. An erect form of the Weeping Forsythia, with the same bright yellow flowers in spring. 2 to $3 \mathrm{ft}$., $50 \mathrm{cts}$. each, $\$ 5$ for $12 ; 3$ to $4 \mathrm{ft}_{\text {. }}, 60 \mathrm{cts}$. each, $\$ 6$ for 12 .

Green Forstrhia. $F$. viridissima. So-called because of its olive-green twigs; erect, greenish yellow flowers rather later than the others. 2 to $3 \mathrm{ft}$., $50 \mathrm{cts}$. each, $\$ 5$ for $12 ; 3$ to $4 \mathrm{ft}$. $60 \mathrm{cts}$. each, $\$ 6$ for 12 .

Spectabilis. $F$. intermedia spectabilis. One of the new hybrid forms and easily the best of the family. 2 to $3 \mathrm{ft}$., 60 cts. each, $\$ 6$ for 12 .

WEEPING. F. suspensa. Very spreading. Flowers bright yellow. 2 to $3 \mathrm{ft}$., $50 \mathrm{cts}$. each, $\$ 5$ for 12 .

\section{Fringe Tree - Chionanthus}

Virginian. Cbionantbus virginica. Small tree with spreading head, covered with threadlike, creamy white flowers in spring. 2 to $3 \mathrm{ft}$., $\$ 1.50$ each.

\section{Genista - Genista}

Tall Woadwaxen. Genista tinctoria (virgata). Vigorous green shrub to 6 feet, covered with bright yellow flowers in spring. Fine for rockery. 4 -in. pot plants, $50 \mathrm{cts}$. each, $\$ 5$ for 12 .

\section{Gold Flower - Hypericum}

GOLD FLower. Hypericum moserianum. Flowers larger and even more brilliant than St. John'sWort. Plant rather lax and best in front of taller things. $50 \mathrm{cts}$. each. $\$ 5$ for 12 .

ST. JoHn's-Wort. H. aureum. A compact, goldenflowered shrub for rockery or sunny position. 18 to $24 \mathrm{in.}, 60 \mathrm{cts}$. each, $\$ 6$ for 12 . the Pink Weigela, (Diervilla florida), may be used. The popular Eva Rathke is dark red, and the plant is lower and perhaps more graceful than the others, and is a striking object.

Spireas make an extremely interesting and very large family. One of them, Van Houtte's, is perhaps the most popular shrub ever introduced. It is usually called the Bridal Wreath, and in Iate May makes a perfect fountain of white with long garlands of tiny, clustered, snowwhite flowers. Earlier than the Bridal Wreath, although similar in type of bloom, are the Garland Spirea (S. arguta) and S. tbunbergi. They are not so large, but are very lovely with their very early sprays of white, when most other plants are bare and lifeless. Perhaps the finest of them aII is the recently introduced Korean Spirea (S. tricbocarpa), which blooms Iater than the Bridal Wreath, having larger clusters of flowers, and making a very fine dome-shaped bush. Because it is really very different from the almost too-popular Bridal Wreath, discriminating gardeners are taking to it eagerly and find it very impressive. There are other Spireas quite different in habit from this group. Anthony Waterer, for example, has flat clusters of duII rose-pink flowers in midsummer. The plant is rather low, and looks weII massed on banks or in broad sweeps at the entrance to drives or in bays or curves among other shrubs. Other pink forms exist which are valuabie for use in the mixed shrubbery, especially where their pink flowers may show above the greens of other vegetation.

The Deutzias are somewhat similar to the Spireas in general effect, but their flowers are Iarger. The pale-pink-flowered Pride of Rochester is an old favorite variety which is much taller than the others, most of which are inclined to a rather dwarf, gracefully drooping habit. Its flowers are exceedingly interesting to examine closely, each having a small funnel or tube in the center made by the flattened filaments of the stamens, so that the resemblance to a tiny narcissus flower is striking.

Of course, one must not overlook the brilliant and friendly Forsythias whose yellow flowers are almost the first real assurance of spring. The new variety, Spectabilis, is really the finest of the family because of the profusion with which its flowers are pro- 
duced and the slightly darker tone of yellow whieh pervades them. It is curious that individual flowers from Spectabilis may be Iaid alongside individual flowers from other varieties and absolutely no difference can be detected in the color; but either on a spray or on the bush the difference between the color masses is so very distinct that other kinds look pale beside it.

The Redbud is Iovely in conjunction with the Dogwood. There is a spot where the famous Conewago Rocks cross the Pennsylvania Railroad, in eastern Pennsylvania, which is a Mecca for all lovers of the beautiful from near and far. Here, among the fantastic, heaped-up boulders, the Red Cedar grows at random, and among it the Dogwood flings its spotless banners, and mingled with them are the Redbud's scattered pink patches. It is a perfect piece of Nature's handiwork-a combination easy to have and a lesson to alI planters.

For early flowers, the Iong wands of the Flowering AImond are especially to be prized. The tiny rosettes of pink and white completely cover the twigs before the leaves come out, making it one of the showiest and prettiest of common shrubs.

\section{Unusual Things}

Many of the choicer varieties of the common Shrubs described above are unusual. Some are rare; but they are greatly to be preferred to the older types. Such plants as the new hybrid Mock Oranges, the Oak-leaf Hydrangea, the lacy Viburnum tomentosum,

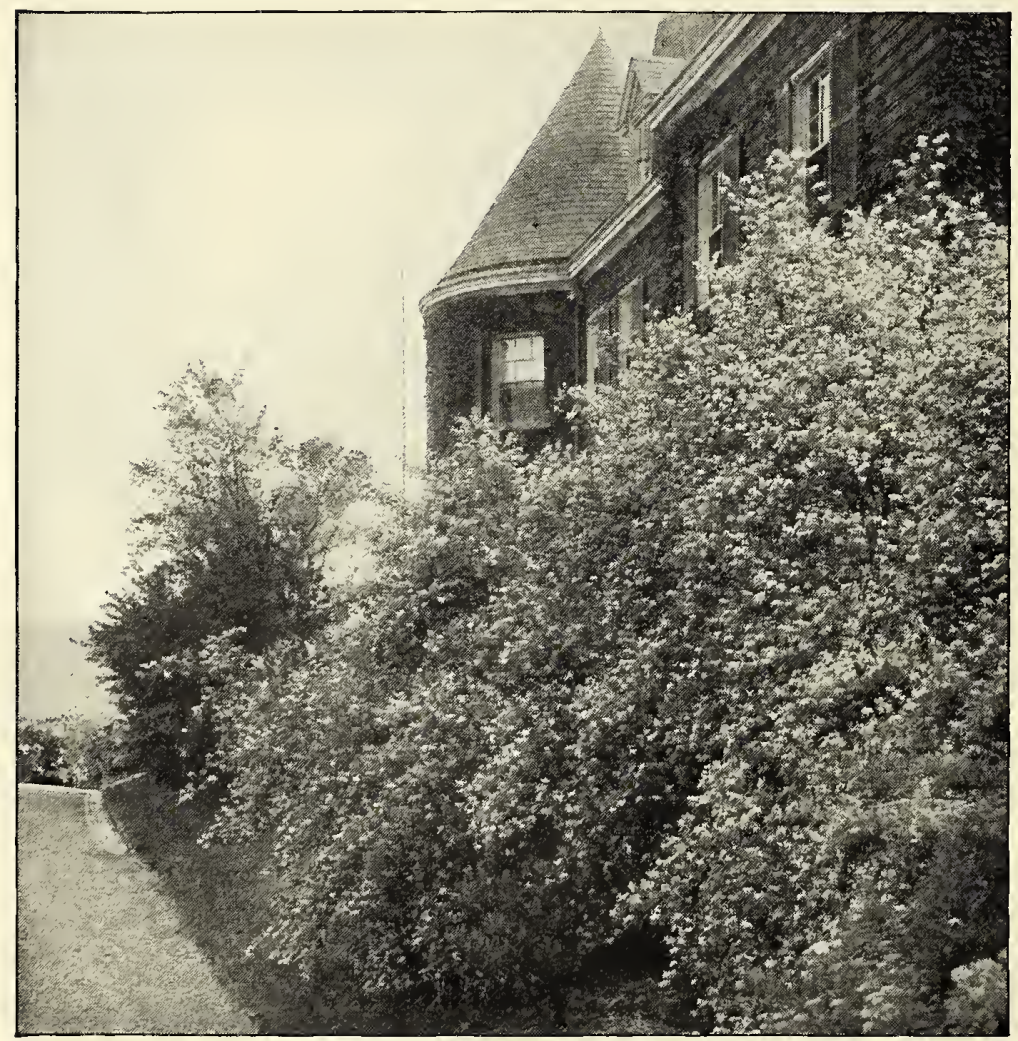

White Belle Honeysuckle bas transformed tbis bouse into a bower of beauty

\section{Hazel · Corylus}

Hazelnut. Corylus americana. Vigorous, ornamental shrub or small tree, native to swales and hollows along water-courses. Flowers not showy, but the nuts are enclosed in a frilly, mossy envelope which is very ornamental. 3 to $4 \mathrm{ft}$., $\$ 1$ each, $\$ 10$ for 12 .

\section{Holly • Ilex}

JAPANESE. Ilex crenata. A very hardy evergreen with dark, glossy leaves and black, shining berries. Can be used as a substitute for Box where it is not hardy. $\$ 2.50$ each.

\section{Honeysuckle, Bush • Lonicera}

European FLy. Lonicera xylosteum. A vigorous. bush about 10 feet high, with cream-white flowers tinged purple, in late spring followed by dark red fruits. 2 to $3 \mathrm{ft}$., $50 \mathrm{cts}$. each, $\$ 5$ for 12 .

MANCHURIAN. L. ruprecbtiana. Large, graceful bush with grayish foliage, white flowers which turn yellow, and brilliant red fruits. Some plants produce yellow berries. 3 to $4 \mathrm{ft}$., $50 \mathrm{cts}$. each, $\$ 5$ for 12 .

Morrow's. L. morrowi. Very graceful, broadbranching shrub about 6 feet high, covered in early spring with white flowers which turn yellow, followed by bright red berries in mid summer. 3 to $4 \mathrm{ft}$., $50 \mathrm{cts}$. each, $\$ 5$ for 12 .

Pink Belle. L. bella (rosea). Slender and erect, with fine pink blooms in May and June, and bright red fruits in August. 3 to $4 \mathrm{ft}$., 50 cts. each, $\$ 5$ for 12 .

TATARIAN. L. tatarica. Vigorous, slender shrub, with very ornamental foliage and rosy pink flowers in early summer. The berries are red and orange and very decorative. 3 to $4 \mathrm{ft}$., $50 \mathrm{cts}$. each, $\$ 5$ for 12 .

White Belle. L. bella. Like Pink Belle, but has white flowers. 3 to $4 \mathrm{ft}$., 50 cts. each, $\$ 5$ for 12 .

White Tatarian. L. tatarica (alba). Like Tatarian but has white flowers. 2 to $3 \mathrm{ft}$., $50 \mathrm{cts}$. each, $\$ 5$ for 12 .

Winter Honeysuckle. L. fragrantissima. One of the most desirable of all. Lovely almost evergreen foliage, and myriads of waxy white, intensely fragrant flowers in late winter. 2 to $3 \mathrm{ft}$., 75 cts. each, $\$ 7.50$ for 12 .

\section{Hydrangea - Hydrangea}

Hills of SNOw. Hydrangea arborescens (grandiflora). A fine low bush about 3 to 4 feet, with large clusters of white flowers somewhat like the Snowball. 2 to $3 \mathrm{ft}$., $75 \mathrm{cts}$. each, $\$ 7.50$ for 12 .

OAK-LEAF. $H$. quercifolia. A rare and very choice variety with handsome leaves, curious bark, and large, showy flowers. 18 to 24 in., $\$ 1.50$ each.

Panicled Hydrangea. $H$. paniculata. A larger, coarser shrub than the above, with immense, conical heads of small, creamy flowers, studded with larger white ones. 2 to $3 \mathrm{ft}$., 60 cts. each, $\$ 6$ for 12 .

Peegee. $H$. paniculata grandiflora. The very popular large-flowered type, with enormous white blooms. 18 to 24 in., 50 cts. each, $\$ 5$ for $12 ; 2$ to $3 \mathrm{ft}$., 75 cts. each, $\$ 7.50$ for 12 .

\section{Itea $\cdot$ Itea}

SWEET SPIRE. Itea virginica. A moisture-loving shrub about 5 feet high, with erect sprays of white, fragrant flowers. 18 to 24 in., 60 cts. each, $\$ 6$ for 12 . 


\section{Juniper • Juniperus}

Pfitzer's. Juniperus cbinensis (pfitzeriana). An evergreen with silvery gray-green foliage and unique plume-like branches which will attain five or six feet with great age. The toughest evergreen for districts fouled with smoke and gases, and can be grown successfully in the most unfavorable locations. 15 to 18 in., $\$ 2.50$ each $\$ 27.50$ for $12 ; 18$ to 24 in. $\$ 4$ each, $\$ 44$ for 12 ; 24 to 30 in., $\$ 6.50$ each, $\$ 72$ for 12 .

Prostrate. J. communis (depressa). Makes dense mats of feathery, evergreen foliage, on banks, hillsides, or on rock-work. Old plants attain great size and may rise to 4 feet in the middle. A superb evergreen for special use. 15 to 18 -in. spread, $\$ 2.50$ each.

SaviN's. $J$. sabina. A trailing, vine-like evergreen which sends up short sprays of feathery foliage 18 inches or less high. Splendid or rock-work or rough banks where it will keep the earth from washing. 18 to 24 in., $\$ 3.50$ each, $\$ 35$ for 12 .

\section{Kerria - Kerria}

Double. Kerria japonica. Tall, green-stemmed shrubs, with small, bright yellow, chrysanthemumlike flowers, produced all summer. 18 to 24 in., 75 cts. each, $\$ 7.50$ for 12 .

SILver. $K$. japonica (argenteo-variegata). Leaves edged white; good with evergreens in foundation plantings. 18 to $24 \mathrm{in}$., $75 \mathrm{cts}$. each, $\$ 7.50$ for 12 .

Single. K. japonica. Similar, but the flowers are like little, single, yellow roses. 18 to 24 in., 75 cts. each, $\$ 7.50$ for 12 .

\section{Laurel • KaImia}

Mountain LaUrel. Kalmia latifolia. Spreading shrub with broad, glossy, evergreen foliage and large clusters of dainty pink and white flowers in early summer. One of the handsomest shrubs. 12 to 18 in., $\$ 2.50$ each, $\$ 25$ for $12 ; 18$ to 24 in., $\$ 3$ each, $\$ 30$ for $12 ; 2$ to $3 \mathrm{ft}$., specimens, $\$ 4$ each, $\$ 40$ for 12 .

\section{Leucothoë · Leucothoë}

LEUCOTнӧ̈. Leucotboe catesbri. Lovely, arching sprays of evergreen, glossy leaves, dark green on top, dark red below. The flowers are in little sprays. Seldom more than 2 feet high. 15 to 18 in., $\$ 2$ each, $\$ 20$ for $12 ; 18$ to 24 in., $\$ 2.50$ each, $\$ 25$ for 12 .

\section{Lilac • Syringa}

Common Purple. Syringa vulgaris. Too well known to need description. 2 to $3 \mathrm{ft}$., $60 \mathrm{cts}$. each, \$6 for 12.

Common White. S. vulgaris (alba). The fragrant white form. 2 to $3 \mathrm{ft}$., 60 cts. each, $\$ 6$ for 12 .

LATE Lrlac. $S$. villosa. A very late-blooming sort with pinkish white flowers and woolly leaves. 3 to $4 \mathrm{ft}$., $\$ 1$ each, $\$ 10$ for 12 .

LuTEA. S. villosa (lutea). A golden leaved variety of the late Lilac with similar flowers. Ornamental in border.. 3 to $4 \mathrm{ft}$., $\$ 1$ each, $\$ 10$ for 12 .

Persian. $S$. persica. A more spreading, smaller shrub than the common Lilac, with large, diffuse sprays of dark violet flowers, 2 to $3 \mathrm{ft}$., $75 \mathrm{cts}$. each, $\$ 7.50$ for 12 .

Persian White. S. persica (alba). The same, with white flowers. 2 to $3 \mathrm{ft}$., $75 \mathrm{cts}$. each, $\$ 7.50$ for 12 .

TREE LILAC. S. japonica. Large shrub or small tree with creamy yellow flowers in Iate June. 3 to $4 \mathrm{ft}$., $\$ 1$ each, $\$ 10$ for 12 .

Wirson's. S. wilsoni. A fine stout shrub, of the Late Lilac type, with pale pink flowers. 2 to $3 \mathrm{ft}$., $\$ 1.50$ each. the fragrant Viburnum Carlesi, the new Korean Spirea, and the gorgeous Forsythia spectabilis must be mentioned here.

With them belongs the wonderful new Beauty Bush (Kolkwitzia amabilis), which has leaped into popular favor within the past two years. A charming, arching bush, covered in spring with smaIl pink flowers like those of a delicate, greatly refined Weigela, it has won a host of friends, and the nurseries are working frantically to keep up the supply. Even when out of flower it is a charming thing, for the long, bending branches are rhythmic patterns of lovely foliage.

Rarely seen in gardens is the fragrant Pepper Bush (Cletbra alnifolia). Although it is now midwinter and the surroundings anything but conducive to happy memories, the bare mention of the Pepper Bush brings back the pleasure of summer on the shores of Buzzard's Bay. There, in the ragged thickets, in a soil of sand and granite, exposed to the four winds of heaven and the devils of the wind and sea, the woods were thick with the Pepper Bush, whose tall spikes of foamy flowers spread far and near their faint, sweet, peppery odor. In the garden it is a handsome late-blooming undershrub of extreme grace and beauty, far from common.

Somewhat similar in use is the Yellow-Root (Xantborrbiza apiifolia), although nothing like it in flower or habit. The plants are low. We say "plants" because it spreads rapidly into dense colonies. Very early in spring, each stem is tipped with a spray of tiny, black, five-pointed stars, most miraculous to look upon. As

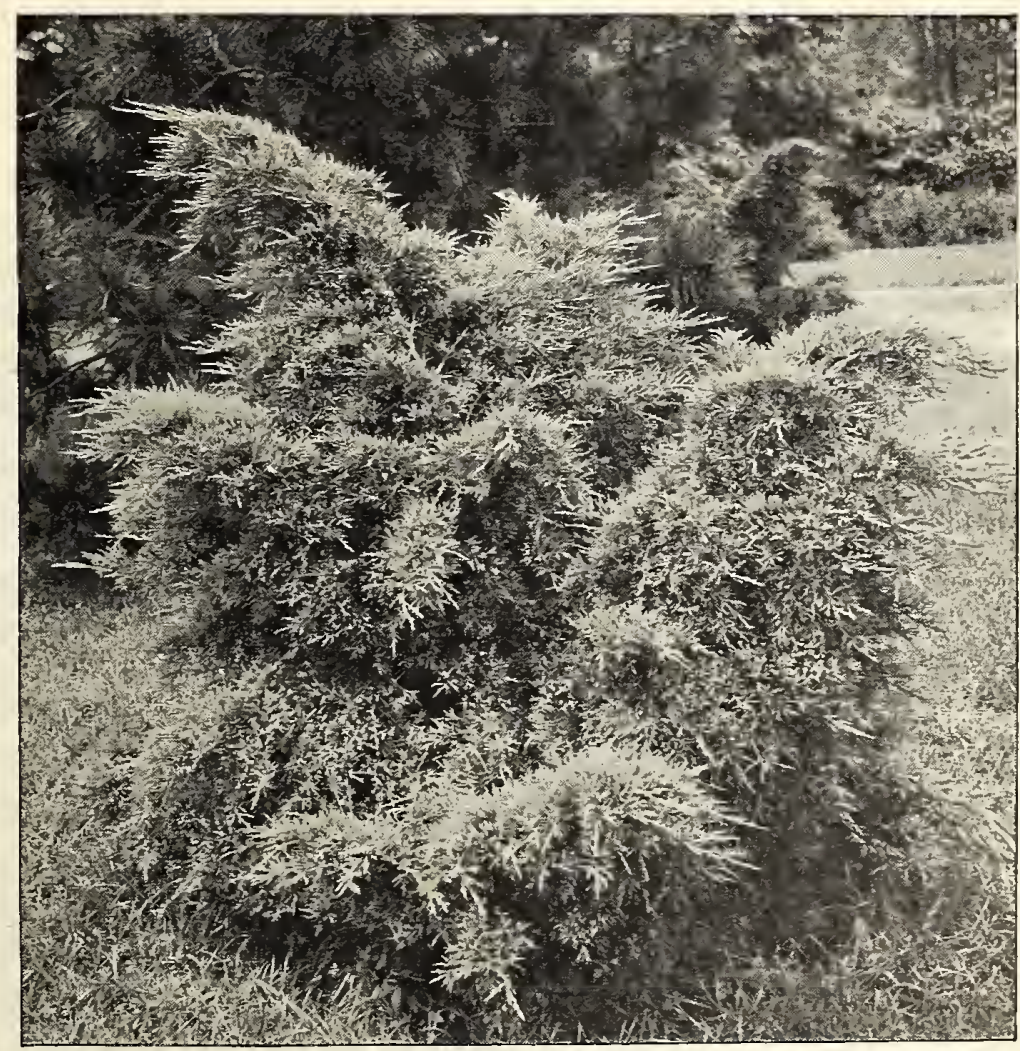

Pfitzer's Juniper will grow in smoky, dust-ridden cities where otber evergreens fail-a fine, sbaggy sbrub of picturesque form 
the leaves unfold they become purple, and Iater brown, and gradually disappear. The leaves are broad, rich, and healthy all summer, and then in autumn they burst into a flame of golden yellow richer and more glorious than any flower. It is a pity this lovely thing is so seldom planted and seen.

Very different, too, are the Gold Flowers, Hypericum aureum and its companion, $H$. moserianum. Charming little shrubs, suitable for sunny banks or a stone-pile, they are covered in summer with flowers of richest yellow, each centered with great masses of clustered, thread-like stamens. These little bushes are very decorous and never get out of bounds, and yet refrain from being stiff and formal.

Another yellow-flowering shrub, but tall and erect, is the Kerria, or Japanese Globe Flower. The single variety has flowers like single yellow roses, but the double ones are perfect balls of gold. Best of all, it blooms on and off throughout the season, so that there is always a spot of color on the bush. Very similar to it, except that its single flowers are white, is Rbodotypos kerrioides, also a charming thing.

Still less seen are the graceful pink spires of the Tamarix, really a small tree which belongs in the background of other shrubs, because the plant is not shapely and needs to be hidden. The long wands of bloom are lovely displayed against the foliage of other plants.

Two gorgeous, yellow-flowering shrubs are included in the Roses-Harison's Yellow and Hugonis. The former is a familiar farmyard shrub, common in all old gardens, and, without doubt, the finest hardy yellow Rose. It spreads very rapidly and in a few years one can have a great bush of it or make a hedge of it. Hugonis is less beautiful but much earlier and valuable for its early color.

Other useful shrub Roses are the very lusty, handsome Rugosas and the Scotch Roses, some of which look like little green cushions

\section{Mock Orange • Philadelphus}

Big Mock Orange. Pbiladelpbus grandiflorus. A large shrub of habit similar to that of Golden Mock Orange, with very large, scentless white flowers. 2 to $3 \mathrm{ft}$., $50 \mathrm{cts}$. each, $\$ 5$ for $12 ; 3$ to 4 ft., 60 cts. each, $\$ 6$ for 12 .

Golden Mock Orange. $P$. coronatius (aureus). A rather dwarf form with bright yellow leaves. 18 to 24 in., 75 cts. each, $\$ 7.50$ for 12 .

Star Mock Orange. $P$. falconeri. Dense, symmetrical growth. with rather small white flowers, shaped like stars. 2 to $3 \mathrm{ft}$., 50 cts. each, $\$ 5$ for $12 ; 3$ to $4 \mathrm{ft}$., 60 cts. each, $\$ 6$ for 12 .

Sweet Mock Orange. $P$. coronarius. The oldfashioned Sweet Syringa, covered with fragrant white flowers in May and June. 2 to $3 \mathrm{ft}$., $50 \mathrm{cts}$. each, $\$ 5$ for $12 ; 3$ to $4 \mathrm{ft}$., 60 cts. each, $\$ 6$ for 12 .

\section{Lemoine Hybrids}

Albatre. A slender, arch ing shrub with clusters of pure white, very double flowers; very fragrant. $\$ 1$ each, $\$ 10$ for 12 .

Avalanche. A tall bush with weeping branches completely smothered in white bloom. \$1 each, $\$ 10$ for 12 .

FAvorite, Very large, single flowers, sometimes 3 inches across. $\$ 1$ each, $\$ 10$ for 12 .

Glacier. A lower bush, with clusters of smaller pure white, double flowers; very fragrant. $\$ 1$ each, $\$ 10$ for 12 .

Mer de Glace. Very fragrant, semi-double, white flowers in prodigal abundance. One of the finest. $\$ 1.50$ each, $\$ 15$ for 12 .

Pyramidal. Erect, rigid bushes with stiff spikes of pure white, double flowers. $\$ 1$ each, $\$ 10$ for 12 .

Virginal. A tall, stiff bush with clusters of large semi-double, pure white flowers, produced on and off all season. $\$ 1$ each, $\$ 10$ for 12 .

SPECIAL OFFER: One each of the Lemoine Hybrids, (7 in all) for $\$ 6.50$

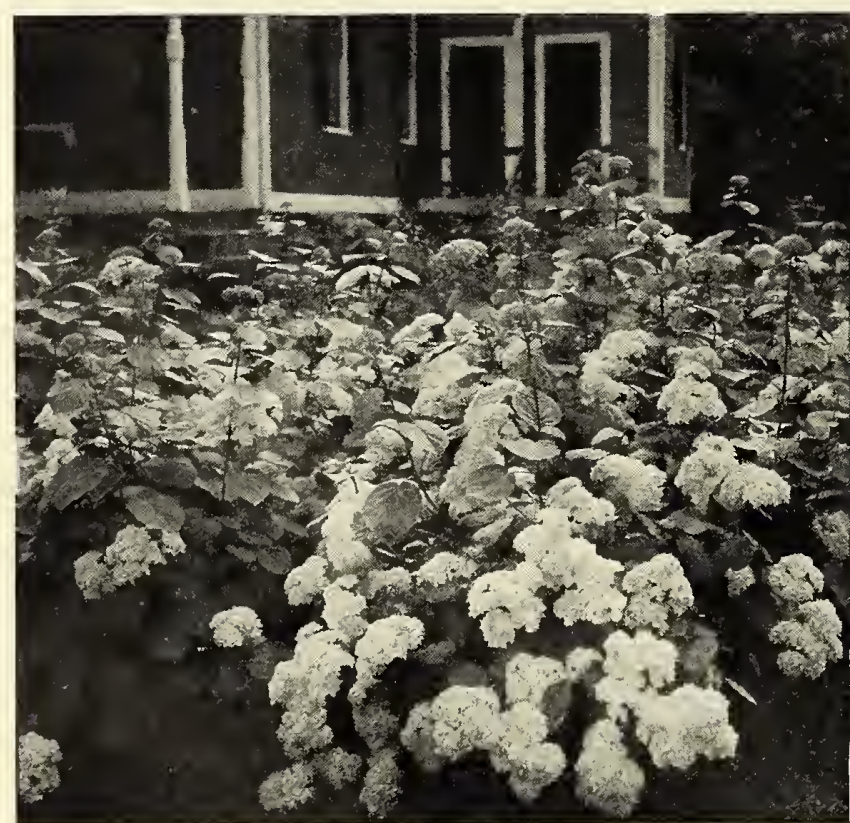

The big white flowers of Hills of Snow Hydrangea

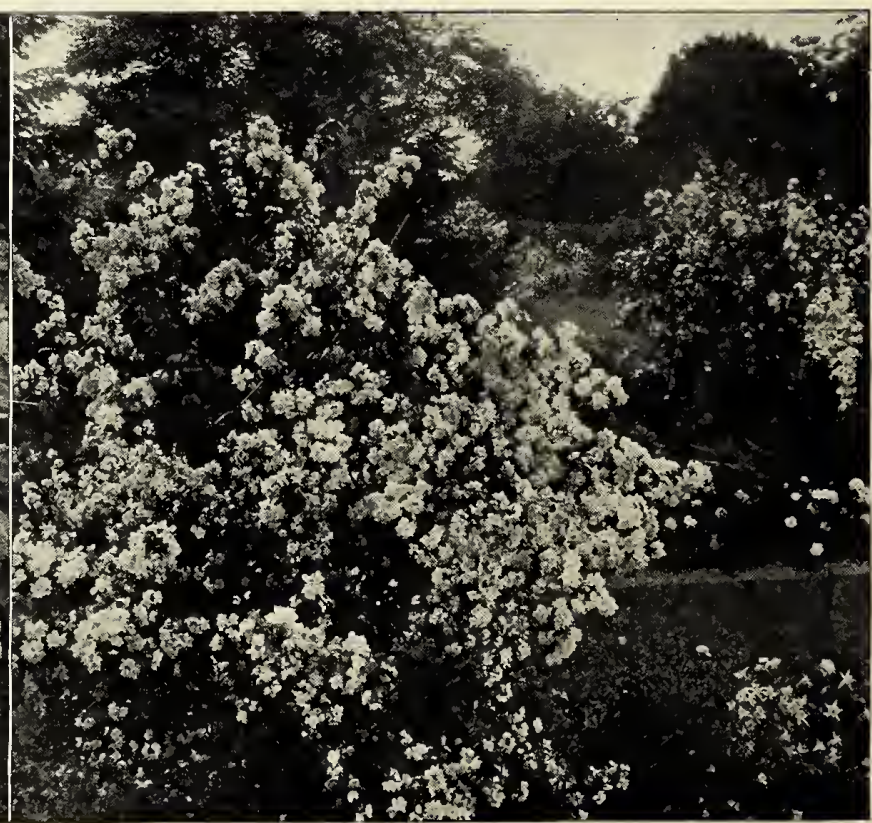

Pbiladelphus Virginal is unsurpassed in splendor 
Ninebark • Physocarpus

Common. Pbvsocarpus opulifolius. Very vigorous. Flowers white, in clusters; bark shredded; fruits large puffed pods of bright red. 3 to $4 \mathrm{ft}$., $50 \mathrm{cts}$. each, $\$ 5$ for $12 ; 4$ to $5 \mathrm{ft}$., 60 cts. each, $\$ 6$ for 12 .

Gold-Leaf. P. opulifolius aureus. Same in habit, flower, and fruit, but the early leaves are bright yellow, turning bronze. 3 to $4 \mathrm{ft}$., $50 \mathrm{cts}$. each, $\$ 5$ for $12 ; 4$ to $5 \mathrm{ft}$., $60 \mathrm{cts}$. each, $\$ 6$ for 12 .

\section{Oleaster - Elæagnus}

Autumn Eleagnus. Eliagnus umbellata. A large shrub to 12 feet, with silvery green foliage and silvery white fruits which turn scarlet. 2 to $3 \mathrm{ft}$., 60 cts. each, $\$ 6$ for 12 .

Cherry Eleagnus. E. longipes. Frosty green foliage and bright red berries on long stalks. A bushy shrub 5 to 6 feet high. 2 to $3 \mathrm{ft}$., $\$ 1.25$ each.

Russian Olive. E. angustifolia. Gray-green leaves with yellow flowers and fruit. Rather tall. 2 to $3 \mathrm{ft}$., $60 \mathrm{cts}$. each, $\$ 6$ for 12

\section{Pearl Bush - Exochorda}

PEARL BUSh. Exocborda grandiflora. A small, slender, tree-like shrub with multitudinous white flowers of great beauty. 2 to $3 \mathrm{ft}$., $75 \mathrm{cts}$. each, $\$ 7.50$ for $12 ; 3$ to $4 \mathrm{ft}$., $\$ 1$ each, $\$ 10$ for 12 .

\section{Pepper Bush - Clethra}

Sweet Pepper Bush. Cletbra alnifolia. Slender, erect stems tipped with tassels of deliciously fragrant flowers in mid-summer. Enjoys shade. 18 to 24 in., 60 cts. each, $\$ 6$ for 12 .

\section{Pine - Pinus}

Mugho Pine. Pinus montana (mugbus). A very dwarf evergreen. Fine for foundation plantings, rockwork, and low, formal effects. 12 to 18 -in. spread, \$3 each; 18 to 24 -in. spread, $\$ 5$ each. studded with starry flowers. They are seIdom seen nowadays, but used to be very popular.

The Silver Bell (Halesia tetraptera), the Sourwood (Oxydendrum arboreum), and the PearI Bush (Exocborda grandiflora), are small trees with white flowers. Of the three, the flowers of the Silver BeIl are the most attractive, the Pearl Bush is most showy, and the Sourwood is gorgeous in autumn, when covered with its large red and orange foliage.

In the small tree class, too, is the Sorbaria, with large panicles of milky, foamy flowers; the various Sumacs, especially the Smoke Tree (Rbus cotinus), which covers itself with a hazy mist, like a drift of autumn smoke; and the Fringe Tree, with a cloud of cream-white, thread-like flowers bearing the ghost of a halfforgotten fragrance.

\section{Shrubs for Fruits and Foliage}

The Privets, so useful for hedges, have fine, glossy, almost evergreen leaves. They are easy to grow, even in desert places, and are much used for formal effects. In the same class are the various Barberries, and one, the recently introduced Red-leaf Barberry, is a very showy plant for lending all-summer color to the shrub planting. It must be planted in full sunlight or otherwise the foliage will turn green. The Bayberry (Myrica carolinensis), is a very special kind of shrub and makes an attractive bush in the most inhospitable places. It grows naturally on the waste sanddunes of Cape Cod, and bears clusters of silvery gray berries of strong, aromatic odor, from which the famous Bayberry candies are made.

Several Honeysuckles have most attractive, glittering red fruit, much surpassing the blossoms in effect, but one

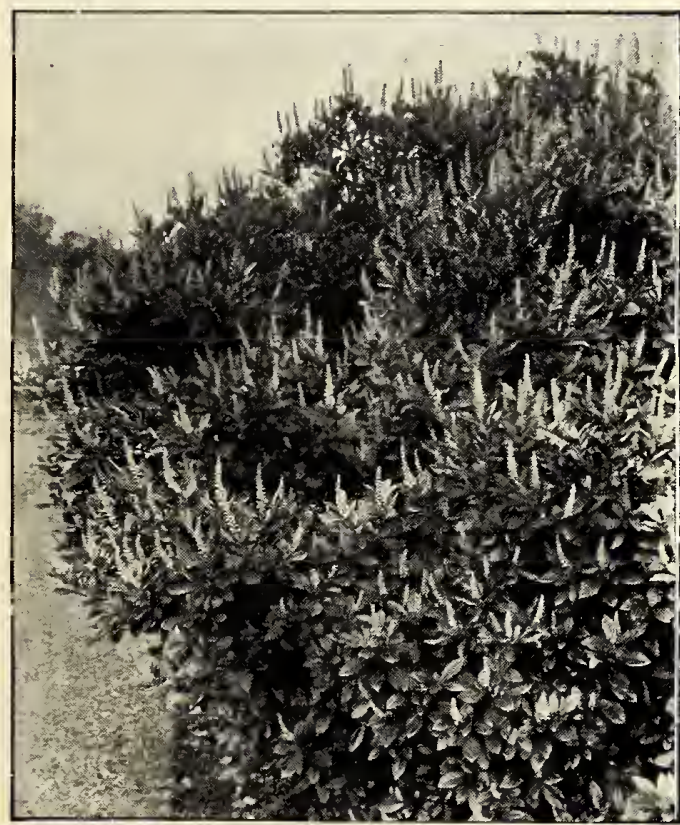

The fragrant little spires of the Sweet Pepper Busb (Cletbra alnifolia)

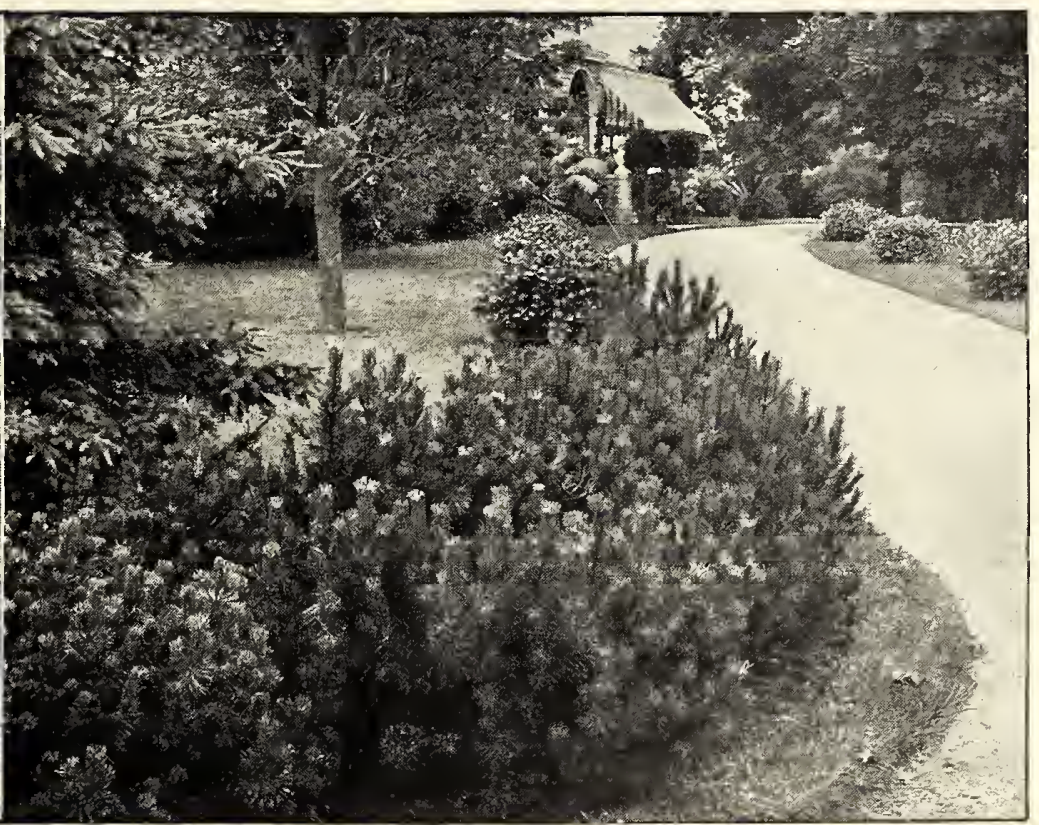

The Mugbo Pine at the edge of a drive. It is always green and bandsome 


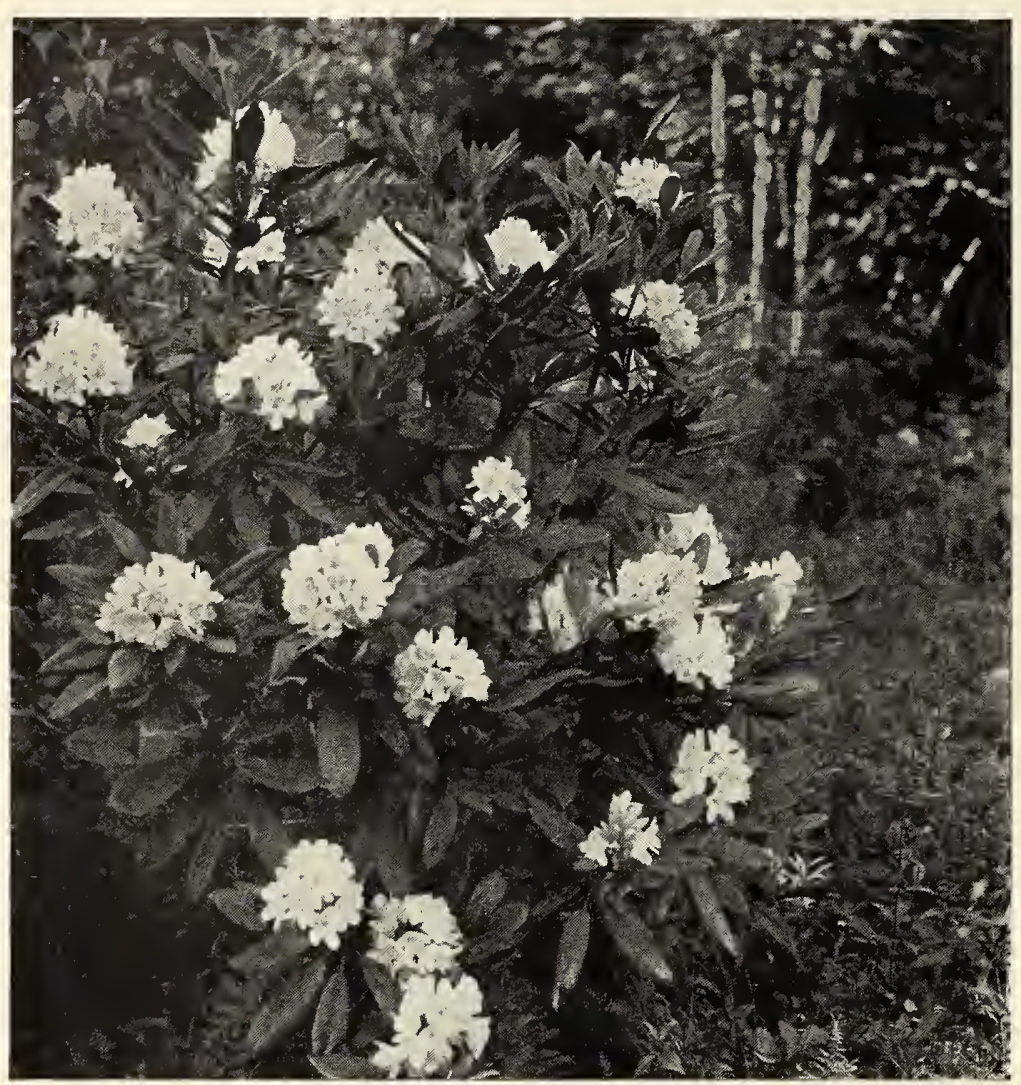

The Rose Bay (Rbododendron maximum) growing in its native bome. Give it the same conditions in the garden

of them, Lonicera fragrantissima, diffuses a fragrance so sweet and piercing that one bush scents the whole garden. AII the Honeysuckles are fine bushes with charming foliage and very gracefuI form. The flowers are not very showy, except those of L. halliana, which, although it is a vine, may be used to advantage as an undershrub or ground-cover.

The Ninebark, with its loose, shaggy bark and its curious, inflated seed-balls, is most interesting, and the common Staghorn Sumac (Rbus typhina), is both brilliant in fruit and autumn foliage. Rubus odoratus, the Purple-flowering Raspberry, is a vigorous, shade-loving shrub with rose-like flowers, followed with very large, raspberry-like fruits. The Snowberry and the Indian Currant, are charming in fruit, and both are good shrubs for rough places. The brilliant, lavender-purple clusters of berries on Callicarpa purpurea deserve a special place beside a gateway or walk where they will be a continual source of pleasure.

For foliage and fruits combined, the silvery green Oleasters are supreme; they have peculiar, frosty green leaves and berries like little olives in all sorts of colors, silvered over with tiny scales. All the Dogwoods have gorgeous fruits. The Flowering Dogwood is described among the Ornamental Trees, but Gray Dogwood (Cornus paniculata) is a handsome, round Shrub with white fruits on red stems which are most attractive. The Silky Dogwood $(C$. amomum) has blue berries and red stems. This whole group of

\section{Privet - Ligustrum}

California Privet. Ligustrum ovalifolium. Much used for hedges, but an excellent, tall-growing, almost evergreen shrub for screens. Withstands any amount of clipping and can be cut into perfect, symmetrical forms. 18 to 24 in., $\$ 2$ for $12, \$ 10$ per $100 ; 2$ to $3 \mathrm{ft}$., $\$ 2.50$ for $12, \$ 12$ per 100 .

European Privet. L. vulgare. The common hedge plant of this type, and the hardiest. Very useful 2 to $3 \mathrm{ft}$., 40 cts. each, $\$ 3.50$ for $12, \$ 20$ per 100 ; 3 to $4 \mathrm{ft}$., $50 \mathrm{cts}$. each, $\$ 4.50$ for $12, \$ 25$ per 100 .

\section{Quince - Cydonia}

Flowering Quince. Crdonia japonica. A spreading, bushy, very rigid shrub, covered in early spring with blazing red flowers which sometimes vary to pink. 18 to 24 in., 60 cts. each, $\$ 6$ for 12

\section{Raspberry • Rubus}

Purple-Flowering. Rubus odoratus. A vigorous, spreading, 4-foot shrub, with large, maple-like leaves and bright purple flowers. The large fruits are red and tasteless. Fine in shade. 2 to $3 \mathrm{ft}$. 40 cts. each, $\$ 4$ for 12 .

\section{Redbud • Cercis}

Redbud (Judas Tree). Cercis canadensis. A small, graceful tree covered in Dogwood-time with multitudes of dark pink, pea-like flowers. 3 to $4 \mathrm{ft}$., $\$ 1$ each, $\$ 10$ for 12 .

\section{Rhododendron - Rhododendron}

Catawba Rhododendron. Rhododendron catawbiense. A gorgeous evergreen shrub, averaging about 6 feet in height, covered with enormous clusters of bright purple-pink flowers in early summer. 15 to 18 in., $\$ 3$ each; 2 to $3 \mathrm{ft}$., $\$ 6$ each.

Rose BAY. R. maximum. The largest and finest of native Rhododendrons. Long, leathery, evergreen leaves and immense quantities of clear, light pink waxen blooms in early summer. 2 to $3 \mathrm{ft}$., $\$ 4$ each, $\$ 44$ for $12 ; 3$ to $4 \mathrm{ft}$., $\$ 6$ each, $\$ 65$ for 12 .

\section{Rhodora • Rhodora}

RHODORA. Rbodora canadensis. A charming little deciduous shrub like a rose-purple azalea. Likes shade, sour soil, and moisture. 18 in., $\$ 2$ each, $\$ 20$ for 12 .

\section{Rhodotypos - Rhodotypos}

WhITE KerRIA. Rbodotypos kerrioides. A dwarf, spreading bush with large 4-petaled white flowers very similar to the Kerria. Good in shady places. 2 to $3 \mathrm{ft}$. $60 \mathrm{cts}$. each, $\$ 5$ for 12 .

\section{Rose - Rosa}

We include here certain Roses valuable for shrub use. Everblooming sorts and climbers will be found on pages 29-33.

Blanc Double de Coubert. Rosa rugosa bybrid. A double-flowered form of the White Rugosa; very handsome and effective. $\$ 1$ each, $\$ 10$ for 12 .

Conrad F. Meyer. $R$. rugosa bybrid. Extremely vigorous Rose with pale pink flowers of lovely form. Grows 10 to 20 feet high without support; blooms most of the season. $\$ 1$ each, $\$ 10$ for 12 .

Harison's Yellow. $R$. feetida. Vigorous, wiry briars covered in late spring with myriads of bright yellow, semi-double flowers. The finest hardy yellow Rose. $\$ 1$ each, $\$ 10$ for 12 . 


\section{DECORATIVE SHRUB S}

\section{ROSES, continued}

Hugonis. R. bugonis. A large, arching bush, covered in early spring with light yellow, single flowers of great charm. One of the earliest to bloom. \$1.50 each, \$12 for 12 .

Persian Yellow. $R$. fatida. Deep golden yellow flowers in spring. A large bush for specimen use or at the edge of shrubbery. $\$ 1$ each, $\$ 10$ for 12 .

Pratrie Rose. R. setigera. Strong, arching, ha $\mathrm{f}$ climbing shrub with brilliant pink flowers in midsumner. 50 cts. each, $\$ 5$ for 12.

Rugosa. R. rugosa. Bold, heavy-caned shrubs up to 8 feet, with rough, handsome foliage and large, cup-shaped flowers of various shades of purple-red and pink produced alI summer and followed by large bright red fruits in autum. 75 cts. each, $\$ 7.50$ for 12 .

Scotch Rose. R. spinosissima. Very spiny, dense bushes with single white or pink flowers in early spring. Fine for mass effects at front of border. $\$ 1$ each, $\$ 10$ for 12.

SWEET Briar. $R$. rubiginosa. Very vigorous thorny bushes with deliciously sweet-scented foliage and small purple-pink flowers along the branches. 75 cts. each, $\$ 7.50$ for 12 .

White Rugosa. R. rugosa (alba). The same as Rugosa, with pure white flowers. $\$ 1$ each, $\$ 10$ for 12 .

\section{Rose-Acacia - Robinia}

Prnk Locusr. Robinia bispida. An extremely beautiful shrub with drooping clusters of bright pink flowers shaped like pea blossoms. 2 to $3 \mathrm{ft}$., $60 \mathrm{cts}$. each, \$6 for 12 .

\section{Silver Bell • Halesia}

Silver Bell. Halesia tetrapteta. Large shrub or tree with bright green foliage and drooping, white flowers like snowdrops, very early in spring. 3 to $4 \mathrm{ft}$., $\$ 1$ each, $\$ 10$ for 12 .

\section{Snowball · Viburnum}

For the two shrubs known as Snowball, see Viburnum.

\section{Snowberry - Symphoricarpos}

Coral Berry. Sympboricarpos vulgaris. A graceful shrub about 4 feet high, covered in autumn with pinkish red berries which are very attractive. 3 to $4 \mathrm{ft}$. 50 cts. each, $\$ 5$ for 12 .

SNowberRy. S. racemosus. An attractive dark green shrub of similar habit, with pink flowers followed by great clusters of pure white, pearly fruit. A good shrub for rough places. 2 to $3 \mathrm{ft}$., 50 cts. each, $\$ 5$ for 12 .

VARIEgated Coral Berry. S. vulgaris (variegata). Exactly Iike the Coral Berry, with bright yellow foliage which is very showy in the border. 2 to $3 \mathrm{ft}$., 50 cts. each, $\$ 5$ for 12 .

\section{Sorbaria - Sorbaria}

FAlse Spire.A. Sorbaria sorbifolia. A handsome beautifully arching shrub or small tree, covered with pointed clusters of cream-white, foamy flowers. 2 to $3 \mathrm{ft} ., 50$ cts. each, $\$ 5$ for $12 ; 3$ to 4 ft., $60 \mathrm{cts}$. each, $\$ 6$ for 12 .

\section{Sourwood • Oxydendrum}

Sourwood. Oxydendrum arboreum. A slow-growing tree useful as a shrub, particularly for the brilliant color of its foliage in autumn. Flowers are white and small, in clusters. 3 to $4 \mathrm{ft}$., $\$ 1.50$ each.

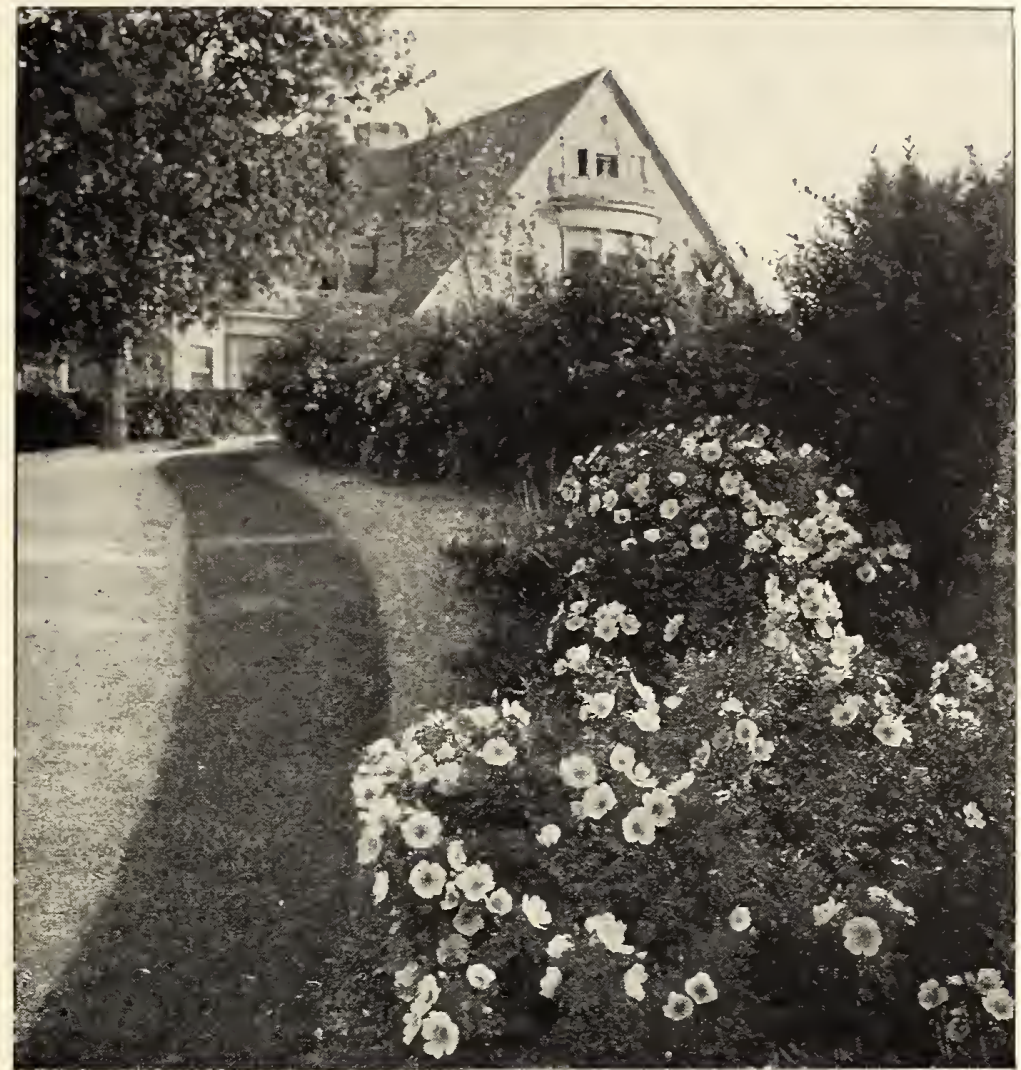

The Scotch Rose (Rosa spinosissima) used to border a driveway. The Rugosas are equally good for tbis purpose

Dogwoods is very interesting, some, like Golden Twig, having brilliant yellow branchlets which are very showy in winter; others, like the Red Osier, are bright crimson; besides several with variously colored leaves.

In fact, all through the shrub section we find plants which have more or less decorative, colored leaves. The Golden Elder is one of these; there are golden-leaved Mock Oranges, and other shrubs have foliage with silver edges and various other markings. In our opinion these are somewhat freakish and much more curious than beautiful, but rightly used in shrub plantings, certain color effects may be obtained which are more permanent than those effected by flowers.

\section{The Evergreen Shrubs}

The dwarf or shrubby evergreens are useful in the shrub planting to provide color, warmth, and foliage decoration during the bare months of winter. Many are so symmetrically shaped that they have distinct beauty of form-the Globe-shaped Arborvitæs, for instance, and the graceful plume-like sprays of Pfitzer's Juniper, and the spreading, upward-curving branches of the Dwarf Yew (Taxus cuspidata brevifolia). AII of them are interesting for the texture of their foliage, which may be rough or velvety in appearance, and for its infinite range of soft refined color. In fact, as we come to appreciate the color effects which may be achieved 
by foliage alone, the various golden and silvery forms of the evergreens acquire greater popularity.

For formal effects, nothing is superior. Certain evergreens in the Ornamental Tree group are especially adapted for this purpose, but the shrub forms are equally useful for places which require less bold treatment, such as at the corners of formal beds, in the angles of low walls, or beside pools. In the rock-garden, too, dwarf evergreens, such as the Savin Juniper, have a place for their rugged, naturalistic appearance, but, perhaps, the greatest opportunity to display their permanent beauty in quantity is about the foundations of the house where they remain in good condition and appearance the year round and always give a neat, attractive finish to the place. In many such plantings small specimens of the large-growing evergreens are used. They are put in to achieve quick results, but must be dug out before they are really established, because they rapidly become too large for the place. It is much more satisfactory to use only the dwarf types in the first place, planting them a little closely at first, and removing the unnecessary ones as they begin to crowd each other. They seldom get too high. The most useful plants for this purpose are the Mugho Pine, variously colored forms of the Arborvitæs, and for very special and rich effects, a few plants of the Dwarf Yew.

\section{Flowering Evergreens}

Because all the broad-leaved or flowering evergreen shrubs require a special kind of treatment, we have omitted them from the discussion thus far. There are no more lovely plants in creation

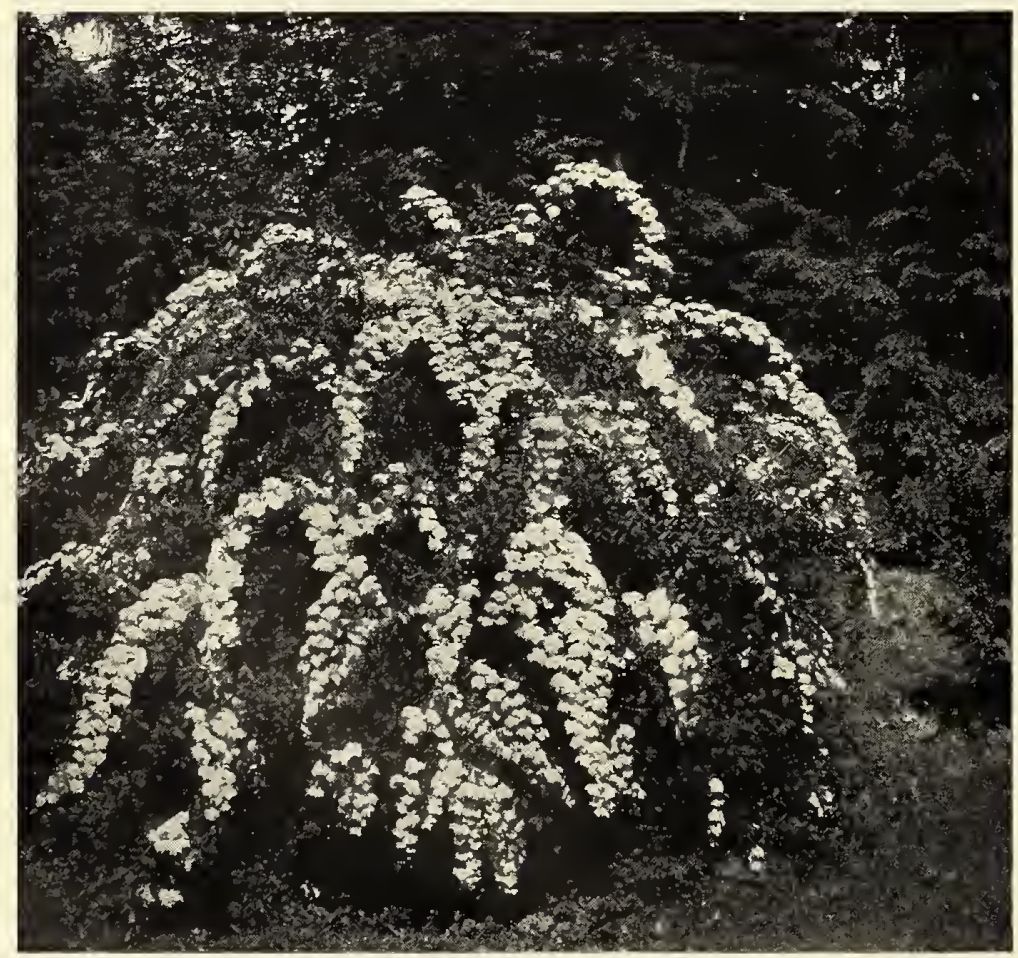

The Korean Spirea (S. trichocarpa), the finest of the new shrubs and a perfect fountain of late, snowy bloom

\section{Spindle Tree • Euonymus}

Burning Bush. Euonymus europæa. Vigorous growth to 10 feet; rich, glossy leaves, and showy bright red fruits in autumn. 2 to $3 \mathrm{ft}$., 60 cts. each, $\$ 6$ for $12 ; 3$ to $4 \mathrm{ft}$., 75 cts. each, $\$ 7.50$ for 12 .

Strawberry Bush. E. americana. A slender shrub to 8 feet, with peculiarly lovely foliage and showy bright pink fruits with scarlet pods. 2 to $3 \mathrm{ft}$., $75 \mathrm{cts}$. each, $\$ 7.50$ for 12 .

Winged Euonymus. E. alata. Similar in appearance but the foliage is brilliant scarlet and orange in autumn and the branches have peculiar corky wings on the bark. 18 to 24 in., $\$ 1$ each, $\$ 10$ for $12 ; 2$ to $3 \mathrm{ft}$., $\$ 1.50$ each.

Yeddo Euonymus. E. yedoensis. A larger shrub with most attractive foliage and bright pink fruits with orange pods. 2 to $3 \mathrm{ft}$., $\$ 1$ each, $\$ 10$ for 12 .

\section{Spirea · Spiræa}

Anthony Waterer. Spiræa bumalda. Low shrub with round, flat clusters of dark pink flowers in midsummer and later. 18 to 24 in., 50 cts. each, $\$ 5$ for 12 .

Douglas' Spirea. S. douglasi. Erect shrubs, 8 feet high, each shoot tipped with spire-like clusters of soft pink flowers. 3 to $4 \mathrm{ft}$., $50 \mathrm{cts}$. each, $\$ 5$ for 12 .

Froebel's Spirea. S. bumalda (froebeli). Similar to Anthony Waterer but taller and brighter in color. 2 to $3 \mathrm{ft}$., $50 \mathrm{cts}$. each, $\$ 5$ for 12 .

Garland. S. arguta. Small, decorative shrub blooming profusely in early spring. Flowers are small, white, and come in great sprays. 2 to $3 \mathrm{ft}$., 50 cts. each, $\$ 5$ for 12 .

Korean Spirea. S. trichocarpa. Splendid domelike bushes with innumerable clusters of white flowers along the branches. The latest to flower. $\$ 1$ each, $\$ 10$ for 12 .

Reeves' SpIRea. $S$ reevesiana. Strong, arching bush about 6 feet high, covered in early summer with double white flowers. 2 to $3 \mathrm{ft}$., $60 \mathrm{cts}$. each, $\$ 6$ for 12 .

Thunberg's Spirea. S. thunbergi. Somewhat like the Garland but earlier. Very graceful. 18 to $24 \mathrm{in}$., $50 \mathrm{cts}$. each, $\$ 5$ for $12 ; 2$ to $3 \mathrm{ft}$., $60 \mathrm{cts}$. each, $\$ 6$ for 12 .

Van Houtte's Spirea. S. vanbouttei. Commonly called "Bridal Wreath." The best known of all and very widely planted. Pure white flowers in May. 2 to $3 \mathrm{ft}$., $40 \mathrm{cts}$. each, $\$ 4$ for $12, \$ 30$ per 100 ; 3 to $4 \mathrm{ft}$., $50 \mathrm{cts}$. each, $\$ 5$ for $12, \$ 35$ per 100 .

White Japanese Spirea. S. japonica (callosa). Very decorative type, something like Anthony Waterer, except that the flowers are white. 18 to 24 in., 50 cts. each, $\$ 5$ for 12 .

\section{Stagger Bush • Pieris}

Stagger Bush. Pieris mariana. Slender shrub about 3 feet high, bearing nodding pinkish flowers before the leaves appear in spring. Long, dark green leaves. $18 \mathrm{in}$., $75 \mathrm{cts}$. each, $\$ 7.50$ for 12 .

\section{Stephanandra - Stephanandra}

LACE Shrub. Stepbanandra flexuosa. A low edging shrub with attractive, deeply cut and fringed leaves and creamy white flowers. 2 to $3 \mathrm{ft}$., 60 cts. each, $\$ 6$ for 12 .

\section{Sumac • Rhus}

Fragrant Sumac. Rbus canadensis. Dwarf shrub for rock-work or rough banks. Yellow, fragrant flowers and bright red berries. 18 to 24 in., 60 cts. each, $\$ 6$ for 12 . 


\section{SUMAC, continued}

Shining Sumac. $R$. copallina. Handsome, dark green, glossy foliage and large clusters of red fruits. Foliage scarlet in autumn. 2 to $3 \mathrm{ft}$. 60 cts. each, $\$ 6$ for 12 .

Shredded Sumac. R. typbina (laciniata). A form of the common Staghorn with finely fringed and cut leaves. Very decorative. 3 to $4 \mathrm{ft}$., $60 \mathrm{cts}$. each, $\$ 6$ for 12 .

Smoke Tree. $R$. colinus. A small, symmetrical, very bushy tree with distinct, shining foliage, covered in late summer and autumn with a cloud of feathery purplish flowers like a drift of mist or smoke. 2 to $3 \mathrm{ft}$., $\$ 1$ each, $\$ 10$ for 12 .

Staghorn Sumac. $R$. typbina. The common hillside Sumac, so brilliant in autumn with its scarlet and orange leaves, and showy in winter with its horn-like clusters of scarlet berries. 3 to $4 \mathrm{ft}$., 60 cts. each, $\$ 6$ for 12 .

\section{Sweet Shrub - Calycanthus}

Strawberry Shrub. Calycantbus floridus. Oldfashioned Sweet Shrub, with intensely fragrant flowers in May. 75 cts. each, $\$ 7.50$ for 12 .

\section{Tamarisk • Tamarix}

African. Tamarix africana. Slender, tree-like shrub of 10 feet, with drooping spikes of small pink flowers. 2 to $3 \mathrm{ft}$., $50 \mathrm{cts}$. each, $\$ 5$ for 12 .

French. $T$. gallica. Similar habit, flowers lighter pink. 2 to $3 \mathrm{ft}$., $50 \mathrm{cts}$. each, $\$ 5$ for 12 .

Odessa. T. odessana. A shrubbier plant, with looser flower-clusters. 2 to $3 \mathrm{ft}$., $50 \mathrm{cts}$. each, $\$ 5$ for 12 .

\section{Viburnum • Viburnum}

ARrow-wood. Viburnum dentatum. A very strong, woody shrub, with handsome foliage and flat clusters of creamy flowers followed by bluish black berries. 2 to $3 \mathrm{ft}$., $50 \mathrm{cts}$. each, $\$ 5$ for 12 ; 3 to $4 \mathrm{ft}$., $60 \mathrm{cts}$. each, $\$ 6$ for 12 .

Carlesi. V. carlesi. A low, shade-loving shrub of rounded form, bearing clusters of waxy pink flowers before the leaves appear, which are deliciously fragrant. 18 to 24 in., $\$ 2.50$ each.

Dwarf Bush Cranberry. V. opulus (nanum). A symmetrical form of the Bush Cranberry, seldom over 2 feet high. 12 to 15 in., 75 cts. each, $\$ 7.50$ for $12 ; 15$ to 18 in., $\$ 1$ each, $\$ 10$ for 12 .

High-Bush Cranberry. V.opulus. 10 to $12 \mathrm{ft}$. high, with fine habit and foliage. Flowers white; fruits large and bright red. 2 to $3 \mathrm{ft}$. 60 cts. each, $\$ 6$ for $12 ; 3$ to $4 \mathrm{ft}$., $75 \mathrm{cts}$. each, $\$ 7.50$ for 12 .

JAPANESE SNOWBall. V. tomentosum (plicatum) Similar to the common Snowball but flowers more compact and later. Foliage very handsome. 18 to 24 in., 75 cts. each, $\$ 7.50$ for 12 .

NanNy Berry. $V$. lentago. Strong, bushy shrub, with fine foliage, yellowish flowers, and large, black berries. 2 to $3 \mathrm{ft}$., $60 \mathrm{cts}$. each, $\$ 6$ for 12 .

SNowball. $V$. opulus (sterile). Well-known large shrub completely covered in May with globular flowers of pure white. 2 to $3 \mathrm{ft}$., $75 \mathrm{cts}$. each, $\$ 7.50$ for $12 ; 3$ to $4 \mathrm{ft}$., $\$ 1$ each, $\$ 10$ for 12 .

Tomentosum. $V$. tomentosum. The handsomest Viburnum. Vigorous, bearing horizontal branches covered with flat, embroidery-like flowers of exquisite beauty. 3 to $4 \mathrm{ft}$., $75 \mathrm{cts}$. each, $\$ 7.50$ for 12 .

WrTHE-Rod. $V$. cassinoides. Erect, vigorous shrub to 15 feet, with clusters of greenish flowers followed by extremely variable and beautiful berries of green, white, pink, blue, and black. 2 to $3 \mathrm{ft}$., $75 \mathrm{cts}$. each, $\$ 7.50$ for 12 . than the Azaleas, Rhododendrons, and others of their type, but to attempt to grow them under the same rough-and-tumble conditions that suffice for more usual things, is to invite failure from the start. All these plants demand a sour soil and plenty of water at all times, although the ground must not be soggy. To do them justice there should be a thorough preparation of the ground, souring it with leaf-mold, peat, or some chemical, usually aluminum sulfate, and this treatment must continue indefinitely if the plants are to be successful.

They are certainly worth the little bit of trouble to spread oak leaves among them in the autumn to decay there, or scattering a handful or two of aluminum sulfate among them several times a season. They like shade, too, but not dense shade, and do well just at the edge of a planting of small trees or larger shrubs.

Whoever has seen the massive, leathery bushes of the great Rhododendron around the little mountain lakes in northern Pennsylvania can never forget the beauty and impressiveness of the sight; and to see the wonderful spread of the pink and white Laurel along the mountain roadsides is an experience equaled by few in this life. And what words are left to describe the frery beauty of the Flame Azalea, or to do justice to the exquisite daintiness of the Pinxter Flower and the Swamp Azaleas, as they cover the waste lands in the wild?

Given the proper conditions described, these flowers will be even finer in cultivation. There are no favorites; we cannot choose if we would. AIl are worthy, all are lovely, and beyond expression the noblest plants that we can grow in our gardens.

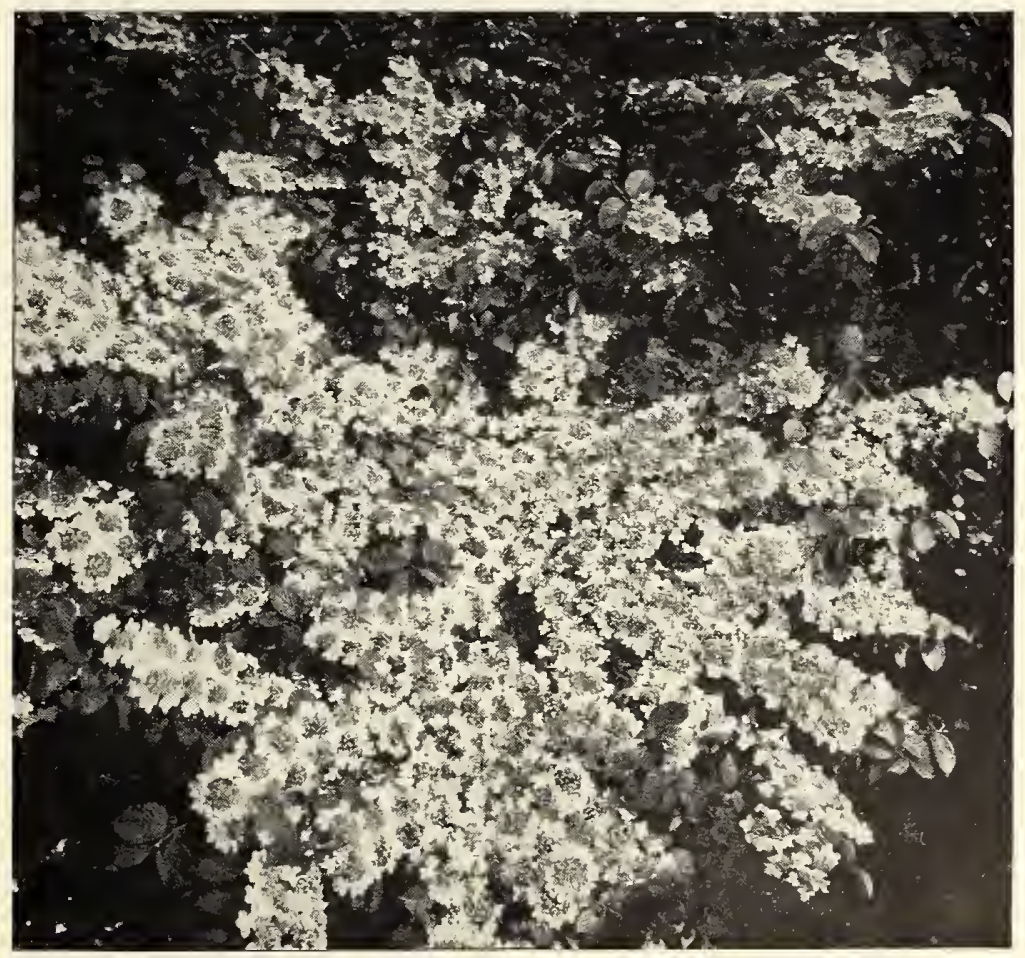

Tomentosum, a shade-loving Viburnum, the most gorgeous of all shrubs when in bloom. It cannot be omitted from any collection 


\section{General Care of Shrubs}

Since they are permanent things, shrubs should have good soil to start with and occasional fertilization from year to year. If the ground between them is allowed to become covered with leaves from nearby trees, which mulch and feed them, their care is minimized. They ought not be planted in a bare lawn with grass growing about their roots. The ground beneath them should be loose, or covered with some low, shallow-rooted plant that will not steal their food.

Most bushes require some restraint or they become unmanageable, especially in small gardens. For several years, the branches may be cut back somewhat, taking care to prune those that bloom in the spring just after they have dropped their flowers and not before they bloom. The Iate summer and autumn-blooming varieties may be pruned in winter or spring.

But as years go on, they accumulate a great body of woody material in their centers with dead and diseased stems among them. These ought to be cut out from time to time and the bushes given a fresh start. In some cases, it pays to cut the whole shrub to the ground, so that it has a chance to renew itself completely and become a young plant again.

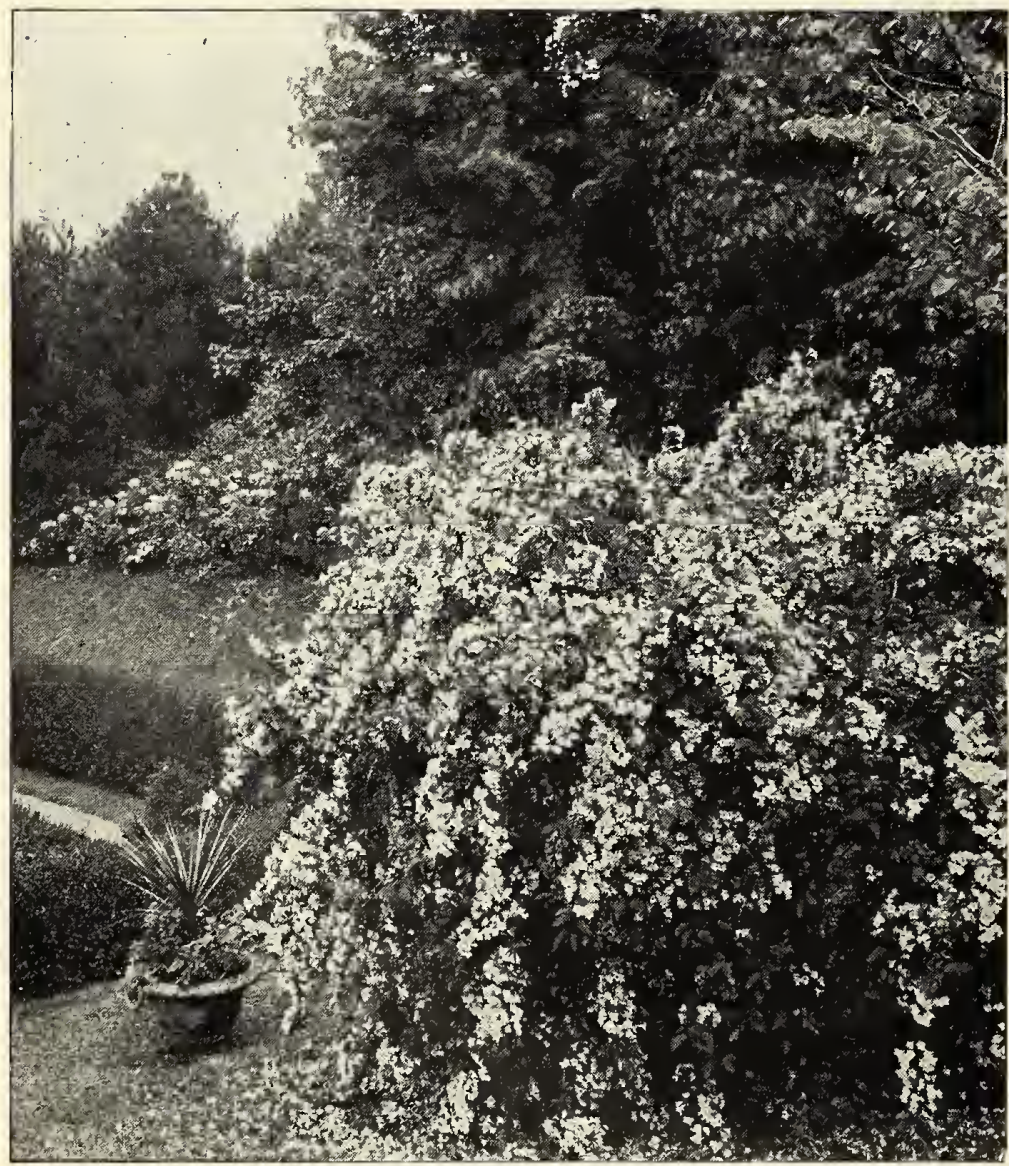

Weigela rosea, the Pink Weigela, is always a joy when covered witb its garlands of graceful flowers
Weigela - Diervilla

Crimson Weigela. Diervilla floribunda. Erect, sturdy bush, covered with bright crimson flowers. 2 to $3 \mathrm{ft}$., $60 \mathrm{cts}$. each, $\$ 6$ for 12 .

Dwarf Bush Honeysuckle. D. trifida. A low, shrubby plant with yellow flowers in midsummer. 18 to 24 in., 50 cts. each, $\$ 5$ for 12 .

Pink Weigela. D. florida (rosea). A fine, strong shrub with large, trumpet-like, bright pink flowers, in great profusion. 2 to $3 \mathrm{ft}$., $50 \mathrm{cts}$. each, $\$ 5$ for $12 ; 3$ to $4 \mathrm{ft}$., $60 \mathrm{cts}$. each, $\$ 6$ for 12 .

Rose Weigela. D. florida (amabilis). A very profusely flowering shrub with very light pink blooms. 2 to $3 \mathrm{ft}$., $50 \mathrm{cts}$. each, $\$ 5$ for $12 ; 3$ to $4 \mathrm{ft}$., 60 cts. each, $\$ 6$ for 12 .

Southern Bush Honeysuckie. D. sessilifolia. Vigorous sbrub up to 5 feet with large, terminal clusters of showy yellow flowers of the honeysuckle type. 2 to 3 feet, 60 cts. each, $\$ 6$ for 12 .

\section{HYBRID WEIGELAS. Diervilla bybrida}

Special and attractive shrubs of vigorous growth, with flowers of various eolors as described below.

Candida. Pure white; very lovely. 2 to $3 \mathrm{ft}$., 60 cts. each, $\$ 6$ for 12 .

DWARF Variegated. Showy green Ieaves, edged white. Flowers white, tinted pink. 18 to 24 in., 50 cts. each, $\$ 5$ for $12 ; 2$ to $3 \mathrm{ft}$., 75 cts. each, $\$ 7.50$ for 12

Eva Rathke. Dark, glowing crimson. 2 to $3 \mathrm{ft}$., 75 cts. each, $\$ 7.50$ for 12 .

Henderson's. Clear, light red. 2 to $3 \mathrm{ft}$., $50 \mathrm{cts}$. each, $\$ 5$ for 12 .

\section{Willow • Salix}

LAurel Willow. Salix pentandra. A very beautiful shrubby tree, 8 to 20 feet tall, with broad, glossy foliage. 4 to $5 \mathrm{ft}$., $75 \mathrm{cts}$. each, $\$ 7.50$ for 12 .

Pussy Willow. S. caprea. The true native Pussy Willow is $S$. discolor, but $S$. caprea has Iarger, showier catkins and is much more effective in the garden. A small tree or large shrub with broad leaves. 4 to $5 \mathrm{ft}$., $\$ 1$ each, $\$ 10$ for 12 .

\section{Witch-Hazel • Hamamelis}

WrTCH-HAZEL. Hamamelis virginiana. A strong, tree-like shrub of picturesque appearance, covered in late autumn or early winter with dull yellow, thread-like flowers along the twigs. The latest shrub to flower. 2 to $3 \mathrm{ft}$., $60 \mathrm{cts}$, each, $\$ 6$ for 12 ; 3 to $4 \mathrm{ft}$., $75 \mathrm{cts}$. each, $\$ 7.50$ for 12 .

\section{Yellow-Root - Xanthorrhiza}

Shrub Yellow-Root. Xantborrbiza apiifolia. Low, spreading, shade-loving undershrub with black flowers and brilliant yellow leaves in autumn. 18 to 24 in., 40 cts. each, $\$ 4$ for 12 .

\section{Yew • Taxus}

American Yew. Taxus canadensis. A low, shrubby evergreen of spreading growth, with leaves somewhat like a hemlock and bright rose-red berries. 18 to 24 in., $\$ 4$ each.

DwarF Japanese Yew $T$ cuspidata brevifolia. A splendid, low, spreading form with dark, almost black foliage. An excellent foundation plant of great resistance to smoke and city conditions. 15 to 18 in., $\$ 4$ each; 18 to 24 in., $\$ 5.50$ each.

SPECIAL DOORWAY PLANTING OFFER, \$20 (Regular Price, \$23)

6 Globe Arborvitæ, 15 to 18 in., balled and burlapped.

2 Pfitzer's Juniper, 18 to 24 -inch spread, balled and burlapped. 

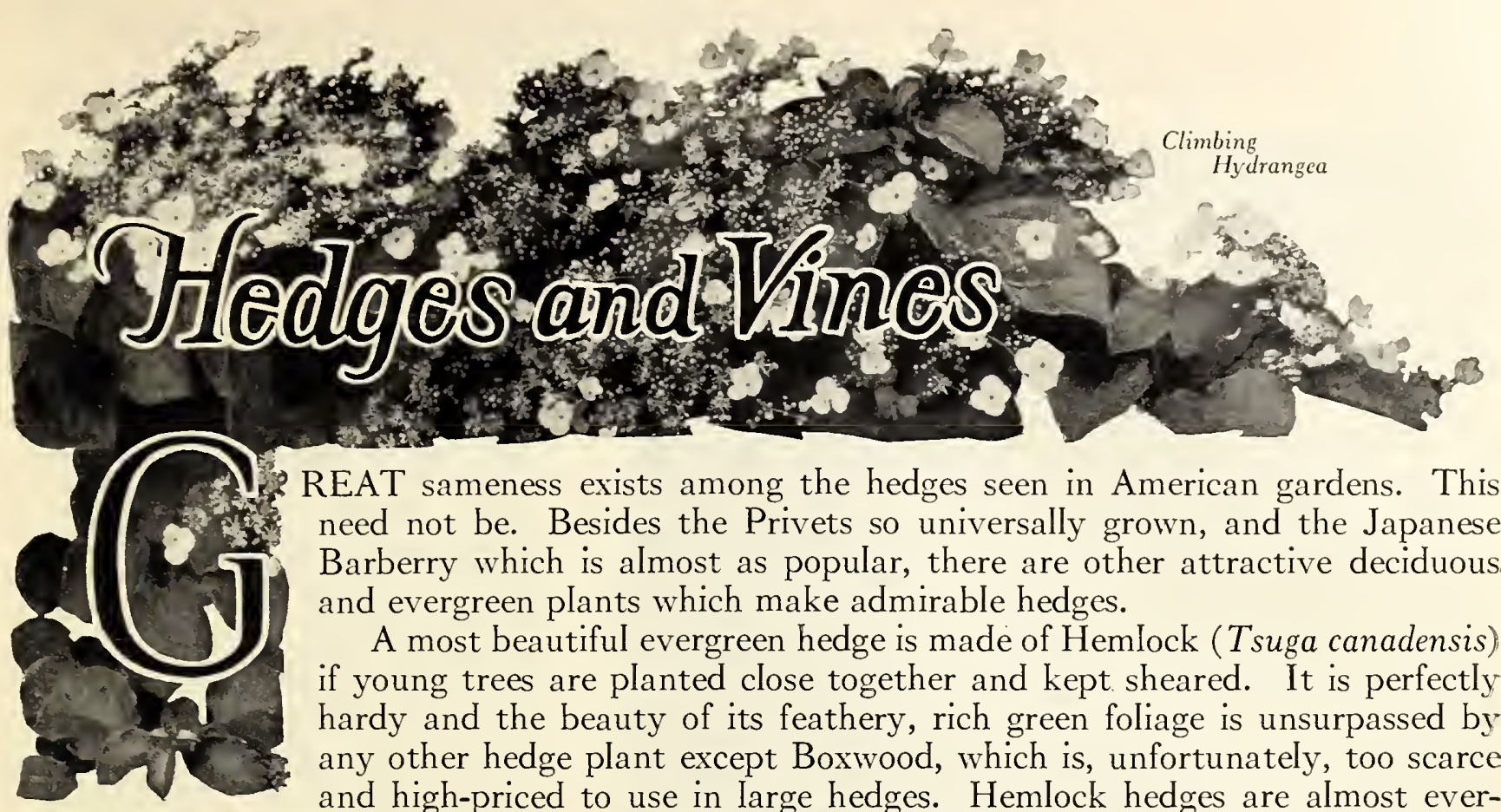

REAT sameness exists among the hedges seen in American gardens. This need not be. Besides the Privets so universally grown, and the Japanese Barberry which is almost as popular, there are other attractive deciduous and evergreen plants which make admirable hedges.

A most beautiful evergreen hedge is made of Hemlock (Tsuga canadensis) if young trees are planted close together and kept sheared. It is perfectly hardy and the beauty of its feathery, rich green foliage is unsurpassed by any other hedge plant except Boxwood, which is, unfortunately, too scarce and high-priced to use in large hedges. Hemlock hedges are almost ever-

Hedge Plants and Vines mentioned in the text, and many otber interesting items are offered in tbis column. For varieties not offered bere, consult tbe Index.

\section{Actinidia - Actinidia}

Actrnidia. Actinidia arguta. Excellent for covering arbors, trellises, and walls because of its handsome foliage. $50 \mathrm{cts}$. each, $\$ 5$ for 12 .

\section{Akebia - Akebia}

Aкebia. Akebia quinata. A hardy, handsome vine. Purple-brown flowers in clusters, followed by dark purple berries. 50 cts. each, $\$ 5$ for 12 .

\section{Arborvitæ - Thuja}

Whrte Cenar. Tbuja occidentalis. The American Arborvitæ or White Cedar is a splendid evergreen hedge plant. 18 to 24 inch, $\$ 2$ each; 30 to 36 inch, $\$ 3$ each; 3 to $4 \mathrm{ft}$., $\$ 4.50$ each.

\section{Barberry - Berberis}

JAPANESE BARBERRY. Berberis thunbergi. Vigorous, graceful, thorny plants with attractive late fruit in autumn. One of the finest plants for hedges. 18 to 24 in., $\$ 3$ for $12, \$ 20$ per $100 ; 24$ to $30 \mathrm{in}$., $\$ 3.50$ for $12, \$ 25$ per 100 .

\section{Berchemia - Berchemia}

Japanese Supplejack. Bercbemia racemosa. A low climber with bright foliage and red fruits in late summer. $60 \mathrm{cts}$. each, $\$ 6$ for 12 .

\section{Bittersweet - Celastrus}

American Bittersweet. Celastrus scandens. An energetic native climber, suitable for covering rocks, stumps, or trees. In autumn or early winter it is brilliant with orange and red fruits, which are frequently cut for house decoration. 50 cts. each, $\$ 5$ for 12 .

Evergreen Bittersweet. See Euonymus.

Japanese Bittersweet. C. paniculatus. Similar to the foregoing, but succeeds in shade and almost any soil. $50 \mathrm{cts}$. each, $\$ 5$ for 12 . lasting and can be kept at nearly any predetermined size by clipping them once or twice a season.

Next to the Hemlock, the most satisfactory evergreen hedge is of White Cedar or American Arborvitæ. It makes a dense, compact barrier but is not so easily restrained as Hemlock and frequently is very rusty-looking in the spring. If a very tall hedge or windbreak is desired, the Arborvitæ is very useful, as it thrives better if allowed to grow more freely than under close-clipped hedge conditions.

The California Privet (Ligustrum ovalifolium) is almost evergreen and very handsome. It is very widely planted and is seen everywhere. The trouble with it is that in severe winters it is likely to be frozen badly. The Amur Privet ( $L$. amurense) is almost identical in appearance but is reliably hardy everywhere and ought to be planted where a neat, formal hedge of medium size is desired.

The Regel Privet (Ligustrum ibota regelianum) is a more vigorous, rougher plant, making a large, thick, gracefully drooping hedge if allowed to grow naturally. It is a little more difficult to keep small than the preceding species and should be used where bolder, showier effects are wanted. It is also a good border shrub because of its dense, low-branching growth.

There is still a great lack of a very low, dense hedge plant to take the place of the Box which is too slow and too scarce to be freely used here. The best substitute we have found is the new Lodense Privet, which we have thoroughly tested and recommend as the best dwarf hedge plant for this climate. By regular shearing it can be kept at any height between 8 and 24 inches, and will make a fine, almost evergreen, solid hedge.

We consider the three Privets described above and the Japanese Barberry the four best hedge plants for general use in America. The Barberry is best used informally as it is more beautiful untrimmed than when cut to a strict hedge pattern, although it will thrive in that fashion, too. It is extremely handsome all year, from 


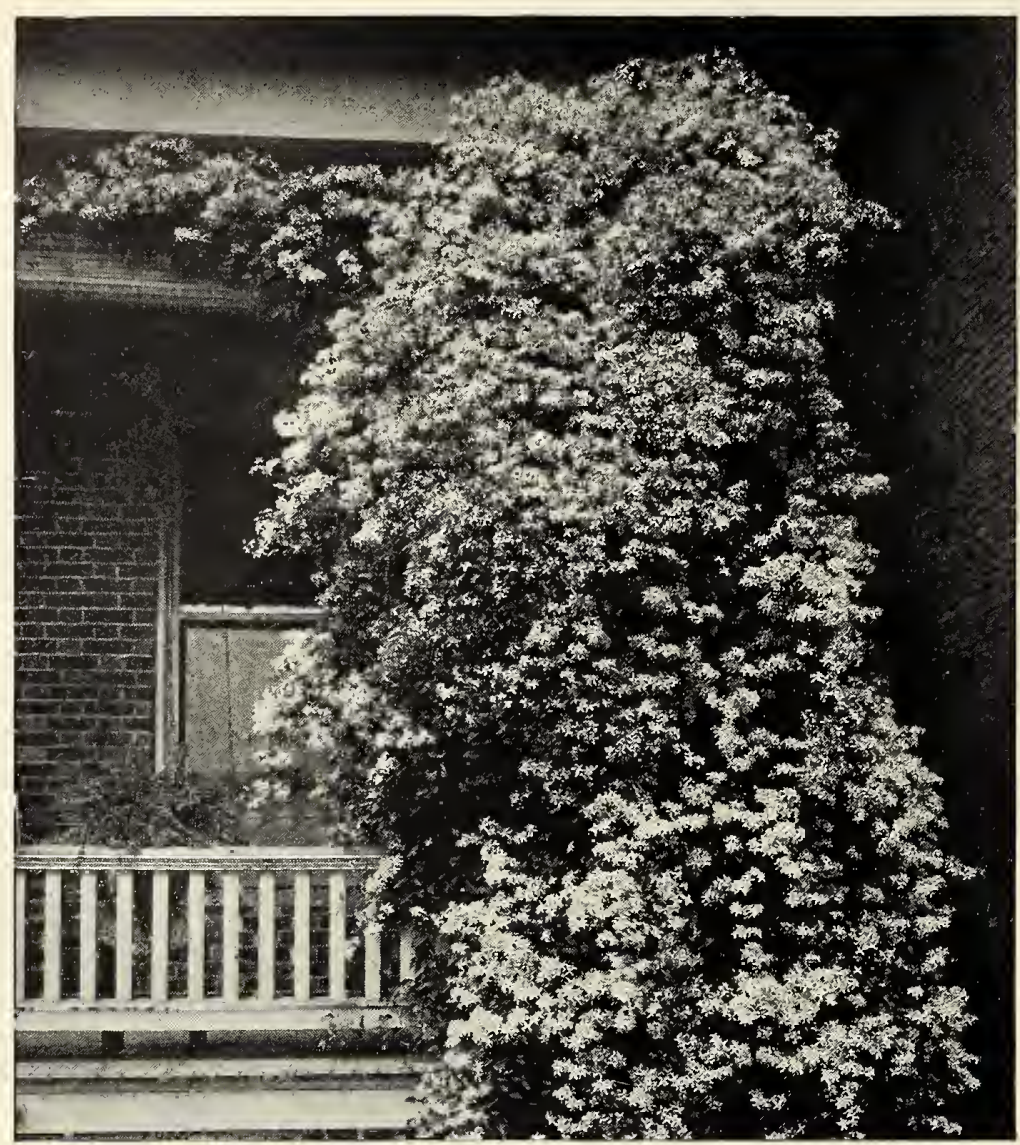

Sweet Autumn Clematis (C. paniculata) growing over a porch. It is one of the best vines for this purpose

early spring when the yellow flowers and fine little leaves appear, to late autumn when it is covered with strings of bright red berries. The gracefully arching habit of its thorny stems, charming design of its foliage, and the brilliant autumn colors which it bears make it a desirable plant at all seasons.

For very tall, dividing hedges, Buckthorn, Hawthorn, Rugosa Roses, certain of the Climbing Roses, supported by a wire, Lilacs, Altheas, and numerous other plants are frequently used. They are all most easily grown and are generally successful.

Vines may be used somewhat for the same purpose as hedges, when trained upon suitable supports, but they consist of so many types of vigor, foliage, flowering, hardiness, and other qualities that each variety requires a little different treatment from the others. The best way to use vines is to determine which would be most suitable for the situation, instead of purchasing a favorite vine and trying to make it grow in a place to which it is not adapted.

Such lovely evergreen vines as the English Ivy may not be hardy on a north wall which it is desired to cover with a dark green, leathery tapestry. In such cases, some other evergreen vine should be used, particularly the Evergreen Bittersweet (Euonymus radicans vegetus). In fact, we are more and more impressed

\section{Buckthorn - Rhamnus}

Rhamnus. Rbamnus catbartica. One of the finest, strong, large hedge plants with dark, glossy foliage and very spiny branches. 2 to $3 \mathrm{ft}$., $50 \mathrm{cts}$. each, $\$ 5$ for $12 ; 3$ to $4 \mathrm{ft}$., 60 cts. each, $\$ 6$ for 12 .

\section{Clematis - Clematis}

Curly Clematis. Clematis crispa. A slender vine with bright purple, fragrant flowers. 75 cts. each, $\$ 7.50$ for 12 .

Scarlet Clematis. $C$. texensis (coccinea). A graceful, low climber with nodding scarlet flowers of great beauty. 75 cts. each, $\$ 7.50$ for 12 .

Sweet Autumn Clematis. $C$. paniculata. This vigorous, graceful climber is covered, in autumn, with small, mist-like, fragrant flowers. One of the most desirable native vines. $40 \mathrm{cts}$. each, $\$ 4$ for 12 .

\section{HYBRID CLEMATIS}

These are climbers of moderate vigor with very large, showy flowers of most brilliant colors.

Henry. Large, creamy white flowers of great beauty. 2-yr. strong plants, $\$ 1$ each, $\$ 11$ for 12 .

JACKмANI. Gorgeous deep violet-purple blooms in great profusion. 2-yr. strong plants, $\$ 1$ each, $\$ 11$ for 12 .

Mme. Edouard Andre. Flowers large, deep rich crimson. 2-yr. strong plants, $\$ 1$ each, $\$ 11$ for 12 .

Ramona. Extra-large, deep sky-blue flowers, of ten 9 inches across. Very vigorous. 2-yr. strong plants, $\$ 1$ each, $\$ 11$ for 12 .

\section{Dutchman's Pipe - Aristolochia}

Dutchman's PIPE. Aristolocbia sipbo. A very vigorous, quick-growing vine, with large leaves and brown, pipe-shaped flowers. Makes an extremely dense shade. $\$ 1$ each.

\section{Euonymus • Euonymus}

Evergreen Bittersweet. Euonymus radicans vegetus. One of the finest evergreen vines for covering walls or bun or shade. Planted closely in a row and kept sheared, it makes an excellent low hedge. Small plants, 35 cts. each, $\$ 3.50$ for 12 , $\$ 25$ per 100; strong pot-grown plants, 50 cts. eaeh, $\$ 5$ for $12, \$ 35$ per 100 .

White-veined Winter Creeper. $E$. radicans reticulatus. Habit, similar to Winter Creeper with mottled cream-and-white leaves. Very decorative. $\$ 3.50$ for $12, \$ 25$ per 100 .

Winter Creeper. E. radicans. A hardy, dense, closely clinging vine; foliage dull green. $\$ 3.50$ for $12, \$ 25$ per 100 .

Grape - Vitis

Frost Grape. Vitis vulpina. The common Wild Grape of the northern states. Excellent vine for rustic effects, covering a large area very quickly. $40 \mathrm{cts}$. each, $\$ 4$ for 12 .

Summer Grape. $V$. æstivalis. A tall, picturesque vine with large, downy leaves. Small, black, very tough fruits. $50 \mathrm{cts}$. each, $\$ 5$ for 12 .

\section{Hawthorn • Cratægus}

English Hawthorn. Cratægus oxvacantba. This, and the other. Hawthorns described on page 7, make excellent impenetrable hedges of great size. Extremely decorative, both in flower, foliage, and fruit. 3 to $4 \mathrm{ft}$., $\$ 1$ each, $\$ 10$ for 12 . 


\section{Hemlock - Tsuga}

Henlock. Tsuga canadensis. The finest native evergreen for hedges. $21 / 2$ to 3 -ft. plants, $\$ 4$ each, $\$ 40$ for $12 ; 3$ to $31 / 2 \mathrm{ft}$., $\$ 5$ each, $\$ 50$ for 12 .

\section{Honeysuckle • Lonicera}

Everblooming Honeysuckle. Lonicera beckrotti. A low climber and a very desirable ground-covering which flowers almost without ceasing all season. The bright scarlet blooms are fragrant in the evening. 50 cts. each, $\$ 5$ for 12 .

Hall's Japanese Honeysuckle. L. japonica (balliana), Much like the Japanese Honeysuckle (L. japonica) but the flowers are pure white and cream, never tinted with purple. $\$ 2.50$ for 12 , $\$ 18$ per 100 .

Japanese Honeysuckle. L. japonica. A quickgrowing vine with dark, almost evergreen leaves and intensely white flowers tinged with purple outside. An excellent ground-covering. $\$ 2.50$ for $12, \$ 18$ per 100 .

Yellow-Net Honeysuckle. L. japonica (aurea) A similar vine with golden verns in its leaves $\$ 2.50$ for $12, \$ 18$ per 100 .

\section{Hydrangea - Climbing Hydrangea}

HYDRANGEA. Hydrangea petiolaris. One of the finest vines in existence and extremely rare. Foliage large and bold, held fast to walls or other support. Flowers rather inconspicuous, in large, flat clusters, studded with Iarge, flaky sterile blooms which are very showy and fragrant. \$1 each, $\$ 10$ for 12 . (See illustration, page 25.)

\section{Ivy $\cdot$ Hedera $\cdot$ Ampelopsis}

The only true Ivy in the following list is the English Ivy (Hedera belix). The others belong to the genus Ampelopsis, and are very closely related to the grapes.

Amur Grape. Ampelopsis beteropbylla amurensis. A luxuriant, close-clinging vine, somewhat similar to the Boston Ivy in habit. $50 \mathrm{cts}$. each, $\$ 5$ for 12 .

Boston Ivy. A. tricuspidata (veitcbi). A very beautiful deciduous vine with smaII, overlapping foliage which turns brilliant red and orange in autumn. The most popular vine in America for covering walls and unsightly objects. 50 cts. each, $\$ 5$ for $12, \$ 35$ per 100 .

Engelmann's Creeper. A. quinquefolia (engelmanni). This form of Virginia Creeper clings more tightly to walls than the original species. It is an extremely useful vine where great hardiness is necessary. 40 cts, each, \$4 for 12 .

English Ivy. Hedera belix. A very vigorous evergreen vine which clings to its support with utmost tenacity, grows rapidly, and lasts forever. $30 \mathrm{cts}$ each, $\$ 3$ for $12, \$ 20$ per 100 .

Virgrnia Creeper. A. quinquefolia. The common native climber commonly called Five-leaved Ivy or Woodbine. Very graceful and rustic in appearance. Foliage bright red in autumn. $40 \mathrm{cts}$ each, $\$ 4$ for 12 .

\section{Matrimony Vine - Lycium}

Matrimony Vrne. Lycium cbinense. A climbing shrub for covering walls, fences, arbors, and trellises, and especially beautiful on banks or rocks. Foliage decorative and persistent, graygreen. Fruits orange-red like tiny tomatoes in long clusters which are very showy and persistent. 35 cts, each, $\$ 3.50$ for 12 .

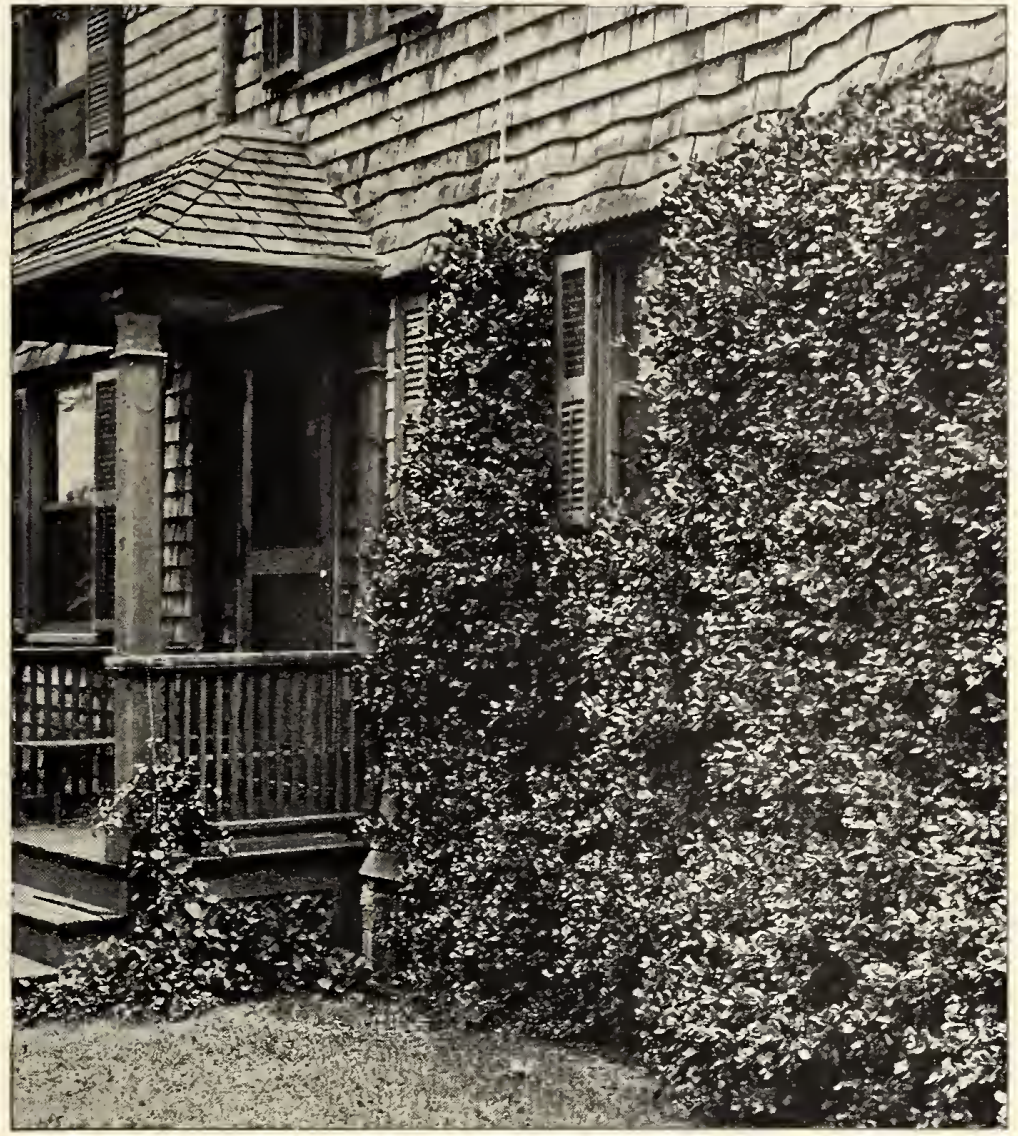

Evergreen Bittersweet (Euonymus radicans vegetus) covering a bouse-wall with its splendid, indestructible mantle of rich green

with the very desirable qualities of this Euonymus. It is a little slow to get started and ought to have protection the first winter after planting, but when it is established it grows with great vigor and is much hardier than any other vine of equal attractiveness.

A most wonderful and extremely choice wall-covering is made by the Climbing Hydrangea, which will rapidly cover a vast expanse of brick or stone with a dark mantle of large, round leaves and flat clusters of flowers which, while inconspicuous in themselves, have a most delicious fragrance. Of course, where climate will permit, one of the loveliest wall-coverings imanable is the English Ivy (Hedera belix). Unfortunately, it will not withstand a great degree of severe cold, and some substitute must be found for it. The Boston Ivy, which grows rapidly and covers everything in sight with a beautiful mosaic of delicately overlapping leaves, is generally most satisfactory although it is not evergreen. A more informal and picturesque vine is Engelmann's Virginia Creeper, which grows with great rapidity and clings with equal tenacity to almost any surface.

These vines may also be used to cover banks or bare ground, exposed rocks or anything which it is desirable to conceal. For the same purpose the common Japanese Honeysuckle is extremely desirable, because of its dense foliage and deliciously scented 
flowers. Perhaps the most desirable of all is the Everblooming Honeysuckle ( $L$. beckrotti) whose bright scarlet flowers are produced more freely than those of any other in the tribe. The Matrimony Vine is especially fine on banks or in corners of walls where its long, drooping sprays, covered with flowers and little berries, may display themselves to best advantage. It is also very satisfactory when trained against a trellis and used as a porchscreen or for a similar purpose.

Where a ground-covering is needed in shady places or under trees, the Periwinkle (Vinca minor) is useful; but the best plant for that purpose is Pachysandra, which is not a vine exactly, but it is a superb, evergreen ground-cover.

For covering arbors or pergolas, a most effective vine is the Wisteria, whose gnarled stems and gracefully drooping flowers have a picturesque quality unapproached by any other plant. For such purposes, too, the Dutchman's Pipe, the various Wild Grapes, particularly the Summer Grape and Frost Grape, are especially useful.

Frequently, tree stumps and poles need to be covered, and in such situations the old Trumpet Climber (Bignonia radicans), the Bittersweet (Celastrus scandens), the Sweet Autumn Clematis (Clematis paniculata), and almost any of the vines previously mentioned may be used. But at present our favorite vine for this purpose or for covering stone walls or training over an arbor is the Silver Lace Vine (Polygonum auberti). Everyone who has seen this remarkable new plant is greatly impressed with the beauty of its sprays of silvery flowers and the gracefulness of its habit, which resembles, in some respects, that of the very popular Sweet Autumn Clematis.

For gorgeous flowering effects in vines, the large-flowering Hybrid Clematis are especially effective, and it is doubtful if any more beautiful vine exists in the world than the weIl-flowered plant of the deep purple, Iarge-flowered C. Jackmani.

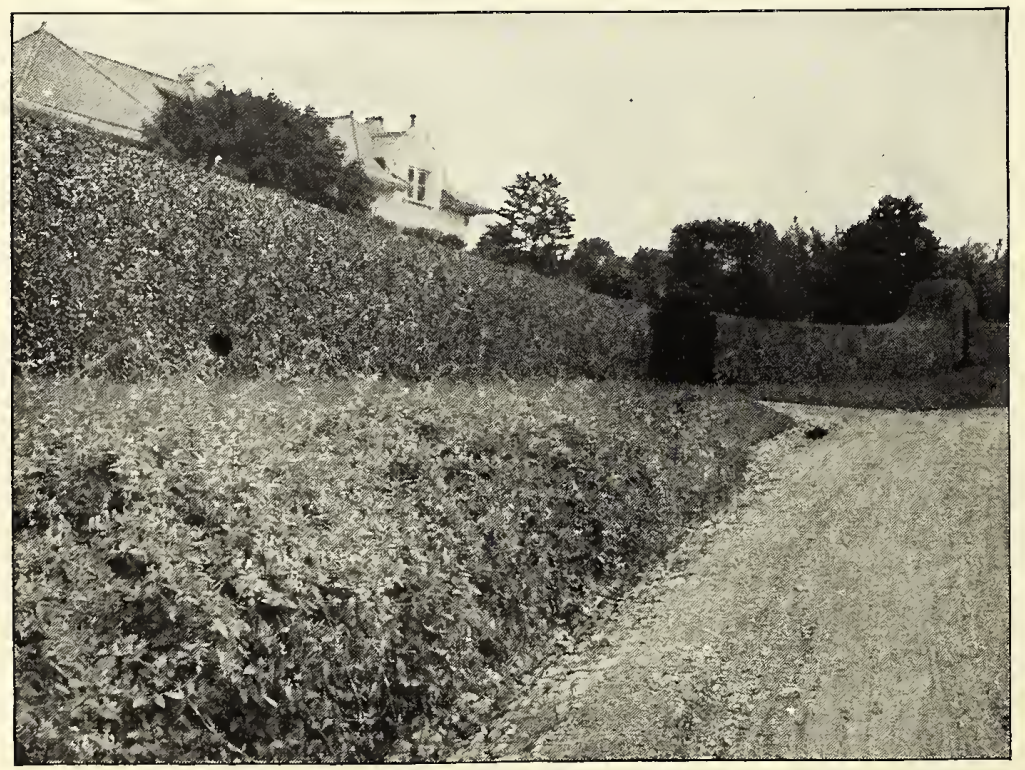

Regel Privet Hedge and a ground-cover of Hall's Honeysuckle on slope
Pachysandra - Pachysandra

JAPANESE SPURge. Pacbysandra terminalis. A dwarf, erect evergreen plant which quickly covers the ground with a sheet of glossy green. Useful in shade. $\$ 2.50$ for $12, \$ 15$ for 100 .

\section{Perennial Pea - Lathyrus}

Pink Perennial Pea. Latbyrus latifolius. Vigorous, bushy vine for covering fences, rocks, rough banks, or to make a shrubby effect in perennial borders. Flowers purplish pink.

Royal Perennial Pea. L. latifolius (splendens). The same but the flowers are brilliant pink.

White Perennial Pea. L. latifolius (albus). The same with snowy white flowers. $\$ 2.50$ for 12 , $\$ 15$ per 100 .

\section{Periwinkle • Vinca}

Periwinkle (Myrtle). Vinca minor. Shrubby trailer, with small evergreen leaves and bright violet-blue flowers. Excellent ground-cover. $\$ 2.50$ for $12, \$ 18$ per 100 .

\section{Polygonum - Polygonum}

Silver Lace Vine. Polygonum auberti. One of the most ornamental of all vines, extremely graceful in habit, and very delightful when covered with its crisp, lacy sprays of pure white bloom. Strong plants, 75 cts. each, $\$ 7.50$ for 12 .

\section{Privet - Ligustrum}

Amur Privet. Ligustrum amurense. Useful hardy plant for medium-sized, well-clipped hedges. Strong, 2 to 3 -ft. plants, $\$ 3$ for $12, \$ 20$ per 100 .

California Privet. L. ovalifolium. A very popular hedge plant where the winter is not too severe. 18 to 24 in., $\$ 2$ for $12, \$ 10$ per $100 ; 2$ to $3 \mathrm{ft}$., $\$ 2.50$ for $12, \$ 12$ per 100 .

Lodense Privet. L. bybrida. Low-growing very dense form of garden origin which we find a quite satisfactory substitute for a low boxwood hedge. 12 to 15 in., $\$ 3$ for $12, \$ 20$ per $100 ; 15$ to 18 in., $\$ 4$ for $12, \$ 30$ per 100 .

Regel Privet. L. ibota (regelianum). A very vigorous, hardy plant suitable for larger hedges than either of the foregoing and for more informal effects. Strong, 2 to $3-\mathrm{ft}$. plants, $\$ 4.50$ for 12 , $\$ 30$ per 100 .

\section{Pueraria - Pueraria}

Kudzu Vine. Pueraria thunbergiana. A swiftly growing vine for a sunny place. Dies to the ground each winter and restores itself the next season. Strong plants, 35 cts. each, $\$ 3.50$ for 12 .

\section{Trumpet Vine - Bignonia}

Trumpet VINE. Bignonia radicans. An energetic vine with picturesque foliage and large, trumpetlike, scarlet and orange flowers. With proper pruning it may be kept as a large, bushy shrub. 50 cts. each, $\$ 5$ for 12 .

\section{Wisteria - Wisteria}

Chinese Wisteria. Wisteria sinensis. Very tall vine with decorative foliage and long clusters of purplish flowers. $\$ 1$ each, $\$ 10$ for 12 .

Magnifica. W. frutescens (magnifica). Tall, stout climber with 6 to 8-inch clusters of lilac flowers with a yellow spot. Blooms quite early. $\$ 1$ each, $\$ 10$ for 12 .

White Chinese. W. sinensis (alba). The same as Chinese Wisteria with white flowers. $\$ 1$ each, $\$ 10$ for 12 . 

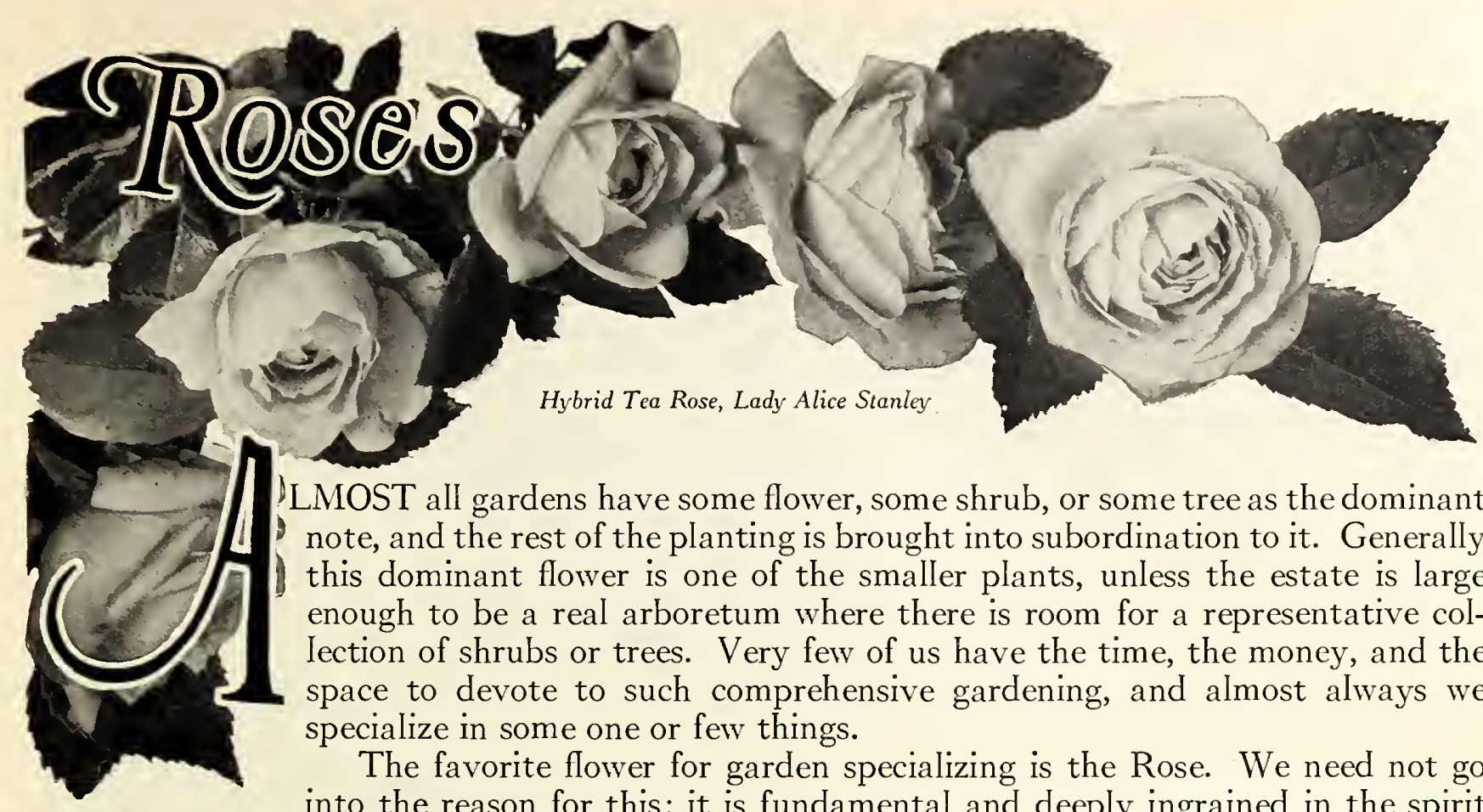

Hybrid Tea Rose, Lady Alice Stanley.

LMOST all gardens have some flower, some shrub, or some tree as the dominant note, and the rest of the planting is brought into subordination to it. Generally this dominant flower is one of the smaller plants, unless the estate is large enough to be a real arboretum where there is room for a representative collection of shrubs or trees. Very few of us have the time, the money, and the space to devote to such comprehensive gardening, and almost always we specialize in some one or few things.

The favorite flower for garden specializing is the Rose. We need not go into the reason for this; it is fundamental and deeply ingrained in the spirit

Tbe Roses mentioned in (be text, and otber interesting varieties, are offered in tbis column. For Roses not offered in tbis section, consult tbe Index.

\section{Climbing Roses}

American Pillar. Light red buds and brilliant pink, single flowers in tremendous clusters. A very strong-growing, glossy-leaved plant. One of the most popular and generally satisfactory Climbing Roses. Very valuable for landscape effects. 60 cts. each, $\$ 6$ for 12 .

Aviateur Bleriot. Very thorny and wiry, suitable for pillars, low arches, or fences. Flowers orange and apricot, paling white as they open. One of the best yellow Climbing Roses. $\$ 1$ each, $\$ 10$ for 12 .

Climbing American Beauty. A very large Rose of unique, brilliant purple-crimson and deliciously fragrant. The plant is not very vigorous but will reach 10 to 12 feet easily. $\$ 1$ each, $\$ 10$ for 12 .

Crimson Rambler. An old and one-time extremely popular small-flowered Climber of brilliant scarlet-red. Very strong, coarse growth which will reach 20 to $30 \mathrm{feet}$ in a season. $75 \mathrm{cts}$. each, $\$ 7.50$ for 12 .

Dorothy Perkins: One of the most charming small-flowered Climbers, blooming in tremendous clusters of bright, glowing pink. The plant is extremely vigorous and very wiry, so that it can be trained into almost any form or used for any purpose. 60 cts. each, $\$ 6$ for $12, \$ 45$ per 100.

DR. W. VAN FleEt. Very strong-growing, thorny plant with rich, glossy foliage, bearing large, pale pink flowers of exquisite form on strong stems, suitable for cutting. The most popular hardy Climbing Rose in the country. $\$ 1$ each, $\$ 10$ for 12 .

Excelsa. Very similar to Dorothy Perkins in habit, except the flowers are bright rosy red. At one time largely planted to replace Crimson Rambler. 75 cts. each, $\$ 7.50$ for 12 .

GARDENIA. A strong-growing Climber with very beautiful glossy foliage and large golden yellow buds which open to attractive, double, creamwhite flowers. One of the finest of the very few hardy yellow Climbing Roses. \$1 each, $\$ 10$ for 12 . of man. It suffices to say that the Rose is considered most beautiful of all flowers and is most eagerly desired in gardens.

Besides the enjoyment one has directly from growing and having the flowers themselves, it is a delightful hobby and a fascinating pastime to learn to know the Rose family, and to associate oneself with others who delight in this phase of gardening. There are many charming and informative books on the subject and most gardening magazines give Iargely of their space and editorial effort to Roses. Two very large and powerful societies devoted to the Rose, the National Rose Society of England, and the American Rose Society, through their publications and activities, are spreading information and assistance throughout the world to all who would enjoy this marvelous flower to the fullest degree.

In fact, it is not only pleasant in itself, but it is becoming quite fashionable to grow Roses and to be able to talk intelligently about them. It is quite as energetic and entertaining as playing golf, and the results from the time and money spent are much more tangible. From it, too, comes a good-humored philosophical contentment in consequence of the genuine good health engendered by reasonable and pleasurable activity out-of-doors.

The Rose family is very large. It includes plants widely different in growth and blooming quality. For garden use, they may be roughly classiffed as Shrubs, Climbers, and Bedding Roses. In the section of this book devoted to Decorative Shrubs, we described several important Roses, and we suggest that they are worth looking up in this connection; but in this chapter we confine our discussion to the Climbers and Bedding types with, perhaps, a few miscellaneous varieties.

\section{The Climbing Roses}

It is not exaggerating to say that, of all the plants possible io grow in this northern climate, there is none more useful and none 


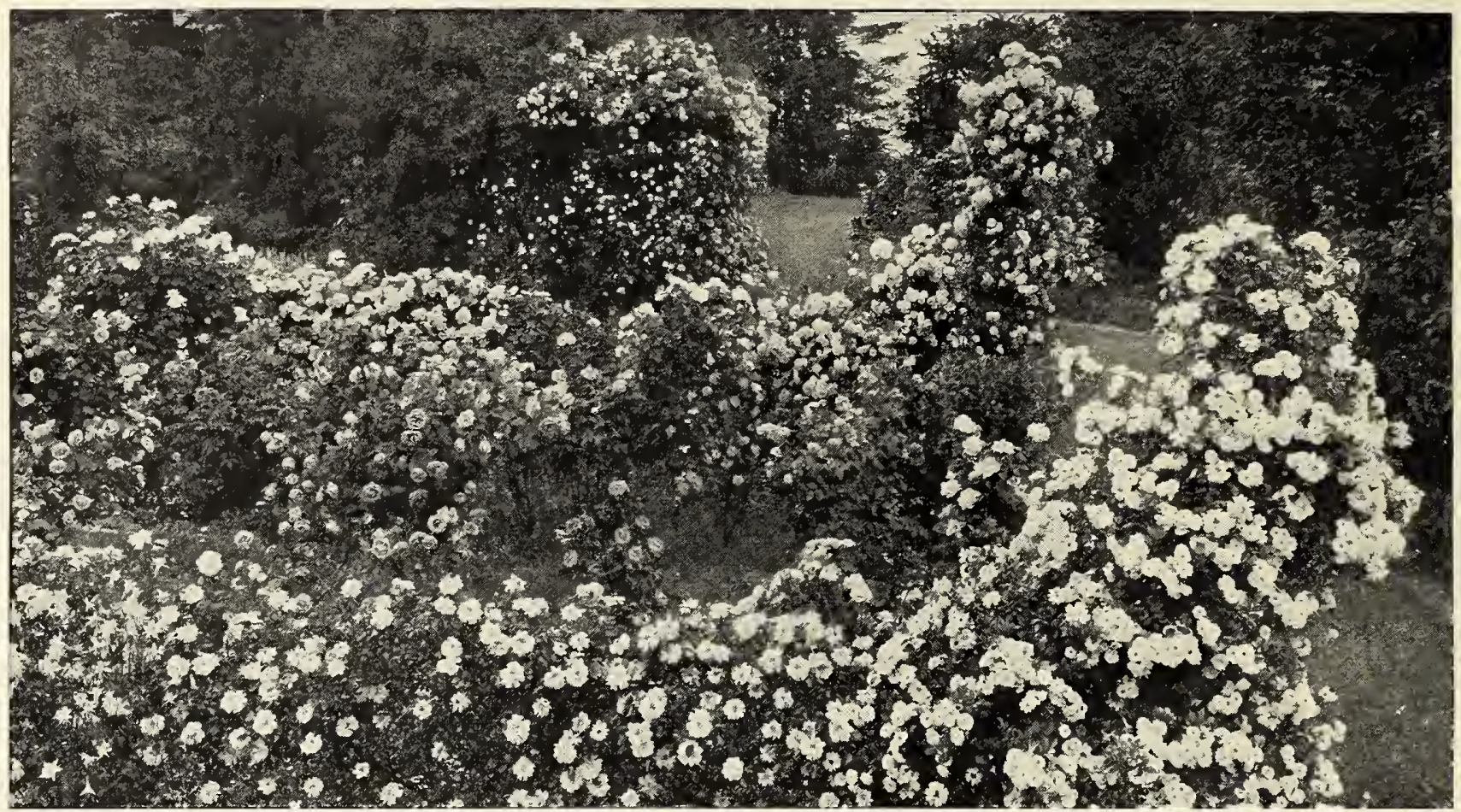

A group of Climbing Roses trained on fences and pillars, Aviateur Bleriot in front row and Tausendscbon at the rear. The beds between are planted with various Hybrid Perpetuals

more splendid in the flower-garden than Climbing Roses. While only a very few of them bloom more than once in a season, the profusion of flowers and their beauty of color more than justify their period of inactivity.

The Climbing Roses may be loosely grouped in two classes: those with small flowers in giant clusters, like American Pillar, Aviateur Bleriot, Excelsa, Hiawatha, Dorothy Perkins, Crimson Rambler, Lady Gay, and White Dorothy; and those with large flowers, sometimes borne singly, but generally in long-stemmed clusters, like Climbing American Beauty, Dr. W. Van Fleet, Gardenia, Mary Wallace, Paul's Scarlet Climber, Silver Moon, and Tausendschon.

The latter class is more generally favored nowadays, but they have not superseded the informal gracefulness of the earlier type as yet. Nothing is sweeter than a rose-arbor covered with the deliciously pink Dorothy Perkins, mingled with a few White Dorothy; and there is still no more dazzling display than a husky, healthy bush of Hiawatha; and even the old Crimson Rambler, if it is planted in the open away from walls, which induce rust and mildew, will blaze away with unparalleled brilliance.

These small-flowered types are best for twining along fences or over arbors because of their long, pliant canes. The bright yellow and orange Aviateur Bleriot is especially lovely treated in this fashion. Excelsa will make a beautiful rosy red fence or hedge, and Lady Gay, which is much like Dorothy Perkins, will make an exquisite arch or gateway.

Because of the great vigor of all these Climbers, they are likely
CLIMBING ROSES, continued

Hiawatha. A lusty, wiry plant of great vigor, bearing Iarge heads of single, bright crimson flowers with white centers and a ring of golden stamens. The general effect is even more dazzling than Crimson Rambler or Paul's Scarlet Climber. $75 \mathrm{cts}$. each, $\$ 7.50$ for 12 .

LADY GAY. Indistinguishable from Dorothy Perkins in habit and bloom, but occasionally produces a cluster or two of flowers in the autumn. $75 \mathrm{cts}$. each, $\$ 7.50$ for 12 .

Mary Wallace. Bright golden pink flowers of great size and lovely form. Especially desirable for cutting. Plant is strong, with beautiful, healthy foliage. Sometimes it blooms in autumn. \$1 each, $\$ 10$ for 12 .

Paul's Scarlet Climber. A moderately growing Climber reaching 8 to 10 feet. Covered in midsummer with a blaze of brilliant scarlet flowers of excellent size and form. Generally considered the reddest Rose in cultivation. $\$ 1$ each, $\$ 10$ for 12 .

Silver Moon. A rampant climber with large, glossy foliage, bearing profusely long, creamy yellow buds which open into flat, almost single flowers of purest white, illumined with Iarge centers of golden yellow stamens. $\$ 1$ each, $\$ 10$ for 12 .

TAUSENDSCHON. A stiff-growing almost thornless Climber of moderate vigor, bearing large clusters of medium-sized flowers which shade from creamwhite to bright pink. A very popular and attractive early-flowering variety. 75 cts. each, $\$ 7.50$ for 12 .

White Dorothy. Exactly like Lady Gay and Dorothy Perkins except that the flowers are pure white. Has the same wiry habit of growth. $75 \mathrm{cts}$. each, $\$ 7.50$ for 12 . 


\section{Hybrid Tea Roses}

These are the Roses most generally planted for cut-flowers in the garden and may be relied upon to produce splendid bloom from June until freezing weather. Our plants are strong, 2year-old, freld-grown.

Strong, 2-year, field-grown plants, in pots, $\$ 1$ each, $\$ 10$ for 12, $\$ 75$ per 100 , except where noted

BRIARCLIFF, Exquisitely shaped buds and blooms of brilliant pink. Rapidly becoming one of the most popular garden Roses as its merits become known.

Columbia. An old favorite. The blooms are very heavy, double, and bright, light pink, deepening in the sunlight as they open.

Dane Edith Helen. New. A novelty which has created a sensation in all the recent flower shows and has shown up weIl in gardens the past season. The flowers are extremely double, exquisitely formed and delicately fragrant. \$2 each.

Dorothy PAge-Ronerts. A very attractive copper-pink variety which blooms unceasingly throughout the season.

Duchess of Wellington. Lovely, Iong copperyellow buds which open to very large, semidouble flowers of pale cream.

Frank Reader. New. Exquisitely shaped buds of light yellow, opening to fine, double flowers of the same color with darker centers. \$2 each.

Gruss an Teplitz. Strong, shrubby plants suitable for borders and backgrounds in the Rose-garden covered continuously with drooping clusters of medium-sized, intensely fragrant Roses of rich velvety crimson.

HADLEY. A splendid little bush bearing glorious dark red blooms on long, strong stems.

Irish Hope. New. A novelty of the past few years which has attracted a great deal of attention because of its brownish red buds and exquisitely formed, rich crimson bloom. $\$ 2.50$ each.

JonkheER J. L. Mock. A favorite old-time variety with enormous dark pink buds, opening to very Iarge, very double flowers which are pale pink inside and almost crimson on the outside.

J. Oтто Thilow. New. Charming sort with bright pink flowers of shell-like form and exquisite texture. Blooms persistently and has excellent stems for cutting. $\$ 2$ each.

Kaiserin Auguste Viktoria. An old and very popular white Rose whose flowers are the most perfectly formed of any grown.

Killanney. A few years ago the most popular Rose in the world because of its Iong, slender, brilliant pink buds and widespread semi-double flowers.

Killarney White. Exactly like Killarney except that the flowers are pure snow-white.

Lady Alice Stanley. A very handsome and dependable old sort, making a strong, robust bush with husky foliage and very large, very double, beautifully formed flowers of light and dark pink. Favorite in everybody's garden.

Lady Margaret Stewart. New. Gorgeous, longpointed buds of deep golden yellow, strongly stained with copper and red, opening to very double, pure yellow flowers of great size. Indications are that it will be a popular garden Rose for many years to come. \$2.50 each.

Lord Charlemont. New. A brilliant crimson Rose of wholly distinct form and color. \$1.75 each.

Los ANGeles. Generally considered one of the most beautiful Roses ever grown. Flowers are pale flesh-pink illumined at the base with shining golden lights and stained with rose and amber. to gct unmanageable and out of bounds within a few ycars unless they are kept cut back quite ruthlessly. The small-flowered varieties mentioned should not be permitted to retain any branch more than two years old. Which means that each summer, just as soon as they have finished flowering, the wood which has borne flowers should be cut away to the base of the plant, and new, strong, green canes trained up for next year's bloom.

As a general rule, the large-flowered Climbing Roses are not quite so rampant as those mentioned, but most of them are strong enough to cover any space, providing they are not severely pruned. In fact, it is just as well to leave some of the old wood on them from year to year, even if it is necessary to cut out some of the new shoots to keep them under controI. Such splendid Roses as Dr. W. Van Fleet and Mary Wallace seem to produce better flowers from the older wood than on the new shoots, and sometimes bloom in the autumn.

While Roses for cutting are generally gathered from the Everblooming or Hybrid Teas, most of the Climbers furnish an abundance of lovely, long-stemmed flowers; and these new, largeflowered Climbers have blooms just as exquisitely fine as the best Hybrid Teas which you buy in the flower shops.

\section{The Bedding Roses or Hybrid Teas}

No garden flowers of any importance may be had in bloom from May till December except Roses, but to have Roses in the garden after the normal June flowering period we must plant Hybrid Teas. They are never very large bushes, seldom over two feet

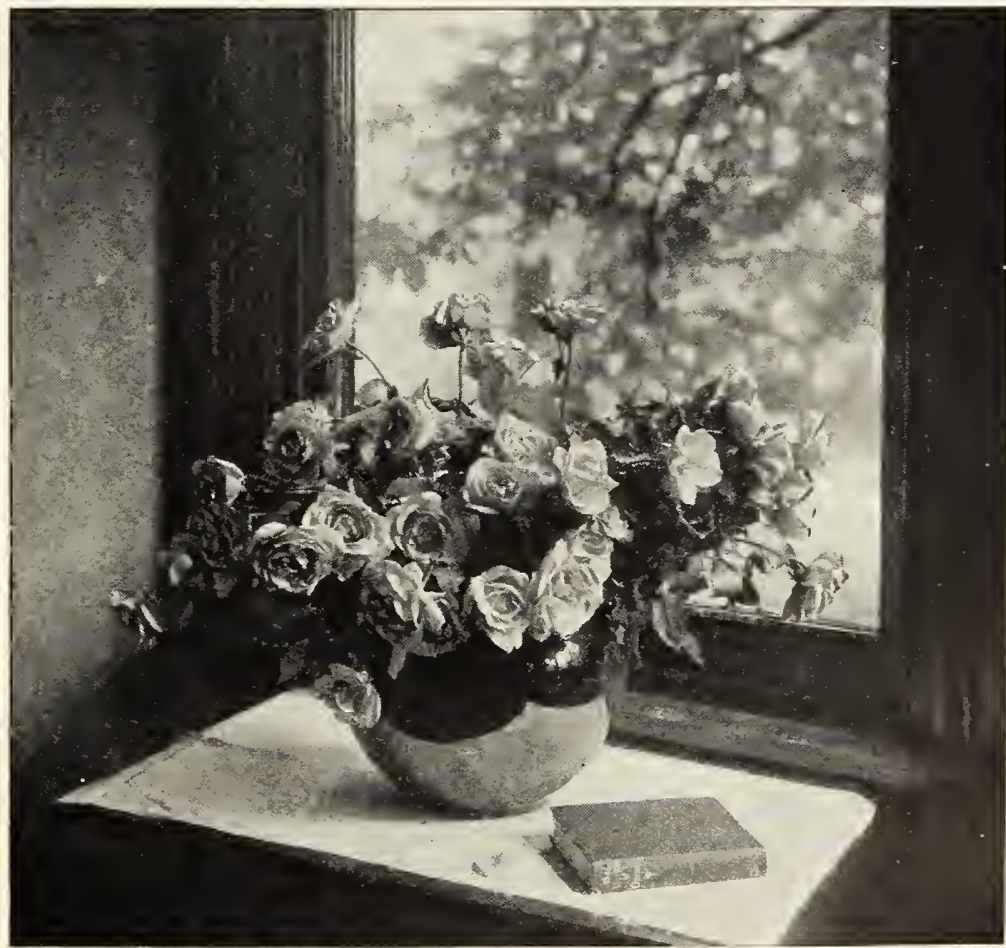

A bowl of Souvenir de Claudius Pernet Roses cut from the garden 31 
high, and do not look well planted singly, and most likely will not thrive. If you want only a few plants for an occasional flower, plant them in a row in the vegetable-garden and hoe and cultivate them like cabbages and turnips; but if you want a lot of fine flowers, give them a little garden, or space to themselves, with rich soil; plant them carefully and see that they never lack protection from their enemies and do not suffer from drought and lack of hoeing. Cared for thus, they will bloom gloriously about ten weeks after planting and continue until freezing weather kills the buds.

Tastes differ so very much and conditions vary from garden to garden so radically that it is difficult to recommend special varieties. Not all do equally well. Some are very shy bloomers; some are naturaIly smaII, weak plants; but all of them have some virtue which has made them admired and desirable. We recommend that you pick out those you like from the written descriptions, do the best you can for them, and if certain ones do not please you, throw them away and try others. Roses are so inexpensive that even the poorest plant more than pays for itself by the blooms it produces the first season. And, besides, the interested gardener always wants to try new and different things each year.

Of the Roses that are almost certain to do well, we recommend a very short list: Gruss an Teplitz, Lady Alice Stanley, Mrs. Wakefield Christie-Miller, Mme. Butterfly, Ophelia, Mrs. Aaron Ward, Radiance, Red Radiance, and Willowmere. These are not the best Roses by any means; they are merely the easiest "doers" and, in general, succeed where others fail. Of those that we admire most for their extreme beauty or fragrance, we suggest: Jonkheer J. L. Mock, Kaiserin Auguste Viktoria, Lady Alice Stanley, Los

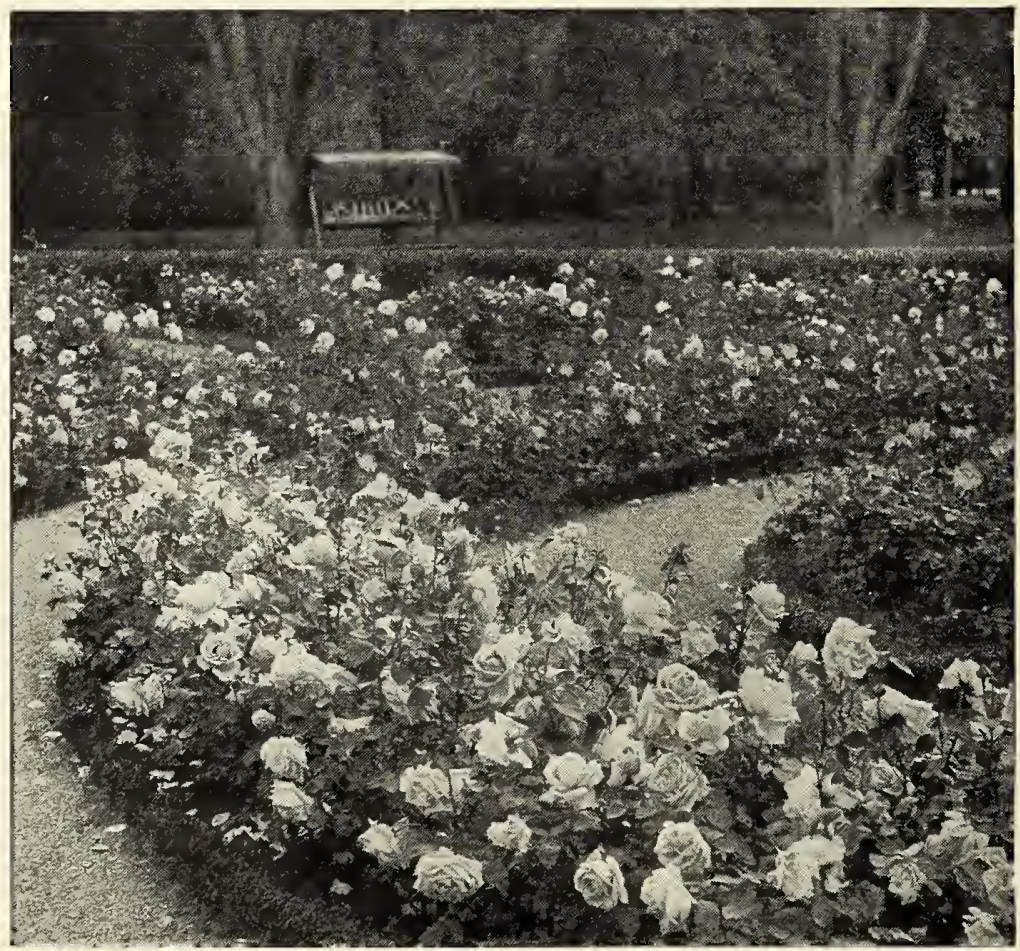

A Rose-garden of Hybrid Teas in the cold climate of Detroit
HYBRID TEA ROSES, continued

Strong, 2-year, field-grown plants. in pots, $\$ 1$ each, $\$ 10$ for 12 , $\$ 75$ per 100, except where noted

Margaret McGredy. New. Robust plants with brilliant green foliage and spiny stems, bearing large globular flowers of most unusual orangescarlet or brick-red. This variety has attracted more attention in the past two years than any other novelty we have ever seen. $\$ 2.25$ each.

Miss Lolita Armour. Handsome, globular flowers with many petals of soft golden salmon, tinged with rose and yellow. A peculiar and very attractive color-combination.

Mme. Edouard Herriot. Most sensational in its brilliant copper-red color, paling as it opens to shining strawberry-pink. One of the most striking Roses ever grown and still very popular.

Mrs. Aaron Ward. A vigorous, low-growing bush with glossy, holly-like foliage, small, frilled buds, and very double, open flowers of apricot-pink and cream. Has long been one of the most popular and widely grown Roses in the garden.

Mrs. A. R. Barraclough. New. Extremely large, lovely blooms of light salmon-pink, beautifully toned and tinged with yellow and deep rose. One of the most persistent bloomers, and the finest novelty of recent years. $\$ 2.50$ each.

Mrs. F. R. Pierson. Bright crimson-red. Very popular in florists' shops.

Mrs. Lovell Swisher. Enormous pale pink flowers, suffused with gold and cream. A new variety from California which is rapidly making a place for itself in the Rose-gardens of the East. \$2 each.

Mrs. Wakefield Christie-Miller. A sturdy, stiff bedding Rose of very neat habit, continually producing large, irregular flowers of the freshest frothy pink imaginable. Favorite in every garden and can always be relied upon.

Ophelia. A good deal like Mme. Butterfly but much lighter. In some seasons it is almost white with just a hint of pink and gold at the base of the petals. It is an extremely popular variety.

Radiance. Perhaps the strongest-growing of the Hybrid Tea class and extremely free-flowering. Blooms are bright pink, globular, and almost fully double. Reports from all over the United States place Radiance first in desirability.

Red Radiance. Exactly like Radiance in habit and blooming quality, but the flowers are bright cherry-red instead of pink.

Red-letter Day. A picturesque shrub, possibly $21 / 2$ to 3 feet high, bearing large, starry, single flowers of pleasing scarlet-crimson. An extremely decorative variety in the garden, especially if planted against an evergreen hedge where its brilliant color is seen to best advantage.

Rev. F. PAge-Roberts. Deep, golden yellow buds stained with crimson and copper, opening into large apricot and golden yellow flowers of the most perfect shape and delicious perfume. It is particularly handsome in autumn. \$2.50 each.

Souvenir de Claudius Pernet. A clear light yellow Rose which has been extremely popular in the past few years. The plant is very satisfactory and the foliage especially fine.

Souvenir de George Beckwith. A tall variety with large, extremely well-shaped blooms of soft salmon-pink.

Souvenir de Georges Pernet. Short, stocky plants with numerous stiff stems crowned with gigantic, brilliant, orange-pink blooms of very fine form. One of the largest Roses and exceedingly striking.

Sunburst. An old-time pale yellow Rose with a slightly deeper center. 
HYBRID TEA ROSES, continued

Strong, 2-year. field-grown plants, in pots, $\$ 1$ each, $\$ 10$ for $12, \$ 75$ per 100 . except where noted

William F. Dreer. An exquisitely beautiful Rose of the Los Angeles type, but much lighter and generally more strongly tinged with yellow.

Willowmere. Beautifully formed flowers of bright coral-pink, illumined with gold and yellow at the center. This is the best variety to grow if Los Angeles fails. They are not exactly alike but Willowmere is generally easier to grow.

\section{Hybrid Perpetual Roses}

Next to the Hybrid Teas, these are the most useful Roses for garden planting. They are very hardy and the flowers extremely fine. Strong, 2-year, field-grown plants, in pots. $\$ 1$ each.
$\$ 10$ per doz., $\$ 75$ per 100

Anna DE Diesbach. Very double; medium size; dark rose-pink.

Captain Christy. Dwarf, with very Iarge peachpink flowers tinted with silver.

Captain Hayward. Lovely crimson buds opening to very large, semi-double, bright red flowers of delicious fragrance. Blooms almost continuously.

Clio. A very strong-growing, spiny plant with round, heavy buds and extremely double flowers of very light pink and white.

FraU Karl Druschki. The most popular white Rose grown. Its flowers are beautifully formed and freely produced from June until frost.

General Jacqueminot. Bright red; semi-double. Valued chiefly for sentimental associations.

Georg Arends. Very large, lovely flowers of the Frau Karl Druschki type and the softest pink imaginable. One of the really fine Hybrid Perpetuals which no garden can do without.

Magna Charta. An old timer with brilliant pink, cup-shaped blooms of delicious fragrance.

Mme. Gabriel Luizet. A somewhat similar variety, a little lighter in color.

Mrs. John LAING. A tall, almost thornless variety, with cup-shaped, double flowers of soft fleshpink. It blooms steadily from June on.

Paul Neyron. Very bushy plants with gigantic double flowers of wonderful, old-rose pink. Blooms more or less all season.

Prince Camille de Rohan. Only moderately vigorous, with rather small, intensely dark purplered flowers of delicious fragrance.

ULRICH BRUNNER. Very vigorous and free-flowering, covered in season with enormous purple-red flowers of great brilliance.

\section{Other Roses}

In the chapter on decorative shrubs we included a number of Roses which are more properly shrubs than flower-garden plants. They will be found on page 20. However, the following Moss Roses belong in the flower-garden proper and should be treated like Hybrid Perpetuals.

Blanche Moreau. One of the most generally satisfactory of the Moss tribe. The buds are quite large, pure white, and heavily clustered with moss. \$1 each, $\$ 10$ for 12 .

Crested Moss. A strong-growing variety with large, brilliant pink buds, surmounted by a hood of feathery moss. \$1 each, $\$ 10$ for 12 .

Salet. Bright pink buds, well mossed and very attractive. This variety sometimes produces a second bloom in autumn. $\$ 1$ each, $\$ 10$ for 12 .
Angeles, Mme. Butterfly, Mme. Edouard Herriot, Souv, de Georges Pernet, Willowmere, and William F. Dreer.

The following comprise a group of Novelties, or New Roses which are recommended for trial. All of them have been grown in this country at least two years and have been recommended to us by prominent Rose enthusiasts. From what we have seen of them in that brief time, we are sure they are worth trying. They are: Dame Edith Helen, Frank Reader, Irish Hope, J. Otto Thilow, Lady Margaret Stewart, Lord Charlemont, Margaret McGredy, Mrs. A. R. Barraclough, Mrs. Lovell Swisher, and Rev. F. PageRoberts.

\section{Hybrid Perpetuals and Other Roses}

Before the Hybrid Teas were created, the most popular Roses were known as Hybrid Perpetuals. They are extremely beautiful, with very Iarge flowers on quite Iarge bushes, but most of them bloom in June only, or have only an occasional flower afterward. Because they are so extremely handsome, and because they withstand cold weather much better than the Hybrid Teas, they are still much grown in the colder parts of the country, and some Rose enthusiasts prefer them to any other type. We have assembled a fair collection of these gorgeous Roses and recommend them. They should be grown in beds, the same as Hybrid Teas, but they need a little more space to develop.

Moss Roses are quite similar in their requirements and are exquisitely Iovely, with sturdy buds encased in a mossy envelope of fragrant green.

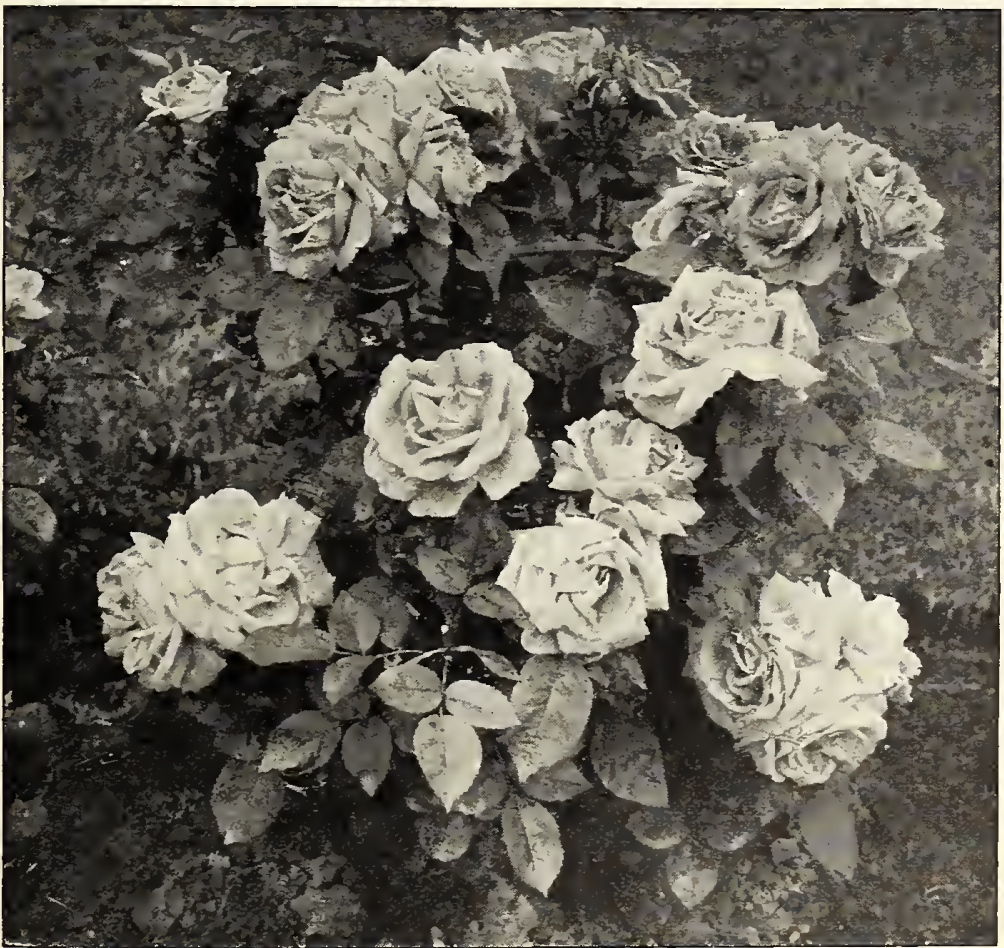

A Hybrid Perpetual, Georg Arends, sbowing babit of plant wben closely pruned 33 

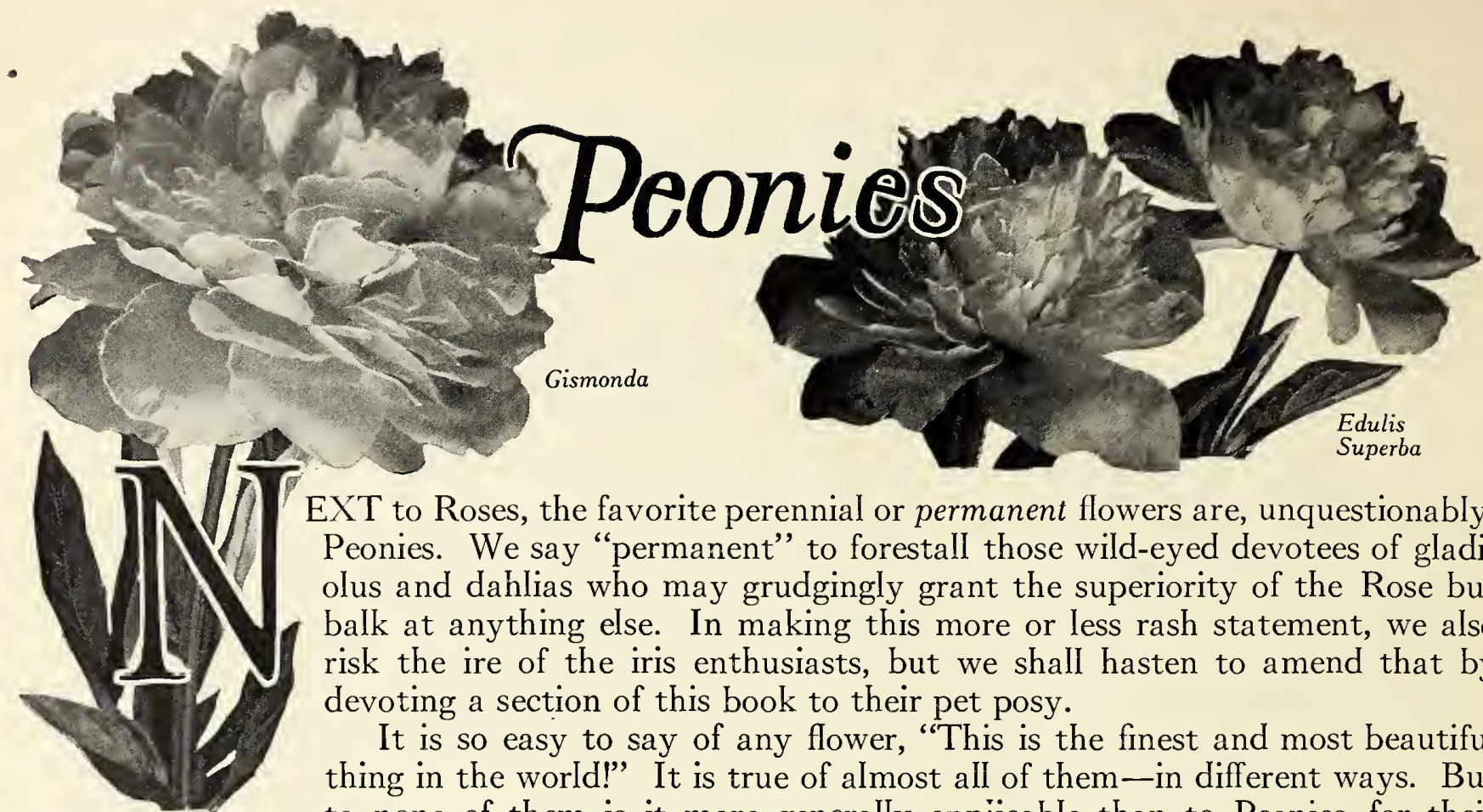

EXT to Roses, the favorite perennial or permanent flowers are, unquestionably, Peonies. We say "permanent" to forestall those wild-eyed devotees of gladiolus and dahlias who may grudgingly grant the superiority of the Rose but balk at anything else. In making this more or less rash statement, we also risk the ire of the iris enthusiasts, but we shall hasten to amend that by devoting a section of this book to their pet posy.

It is so easy to say of any flower, "This is the finest and most beautiful thing in the world!" It is true of almost all of them-in different ways. But to none of them is it more generally appiicable than to Peonies for their unrivaled magnificence, hardiness, healthiness, and permanence.

More than twenty years ago, J. Wilkinson Elliott, the founder of this business, wrote: "It gives me great pleasure to see the increasing popularity of Peonies, for there is nothing more deserving; and when the merits and beauty of the newer varieties are known, every garden will contain a large collection. Like the Irishman's whiskey, all varieties of Peonies are good, even the commonest old-fashioned sorts, but there is no language to describe the glorious beauty of the finest of the newer varieties." That was true and important a score of years ago, and is ten times more important now, because twenty years have brought about an astonishing increase in the cultivation of Peonies throughout America.

Last year, the American Peony Society published its authoritative Manual in which about three hundred seleeted varieties were most carefully described. In it, too, are recorded the names of hundreds and hundreds more which it recommends to be discarded; not because they are unworthy flowers, but because the selected list contains others of similar appearance which are more desirable.

Choosing from these modern Peonies, it is impossible to make a wrong selection. The appetite for these gorgeous flowers need be restrained only by what you can afford.

To one who has never grown Peonies before, we suggest choosing a dozen or so moderately priced varieties from those rated 8 or over, and adding more expensive sorts in small quantities from year to year.

In the old days, we used to see clumps of Peonies-or "Pineys" we called them then-struggling with weedy, uncut grass in almost every dooryard. We have learned to treat them better now, by giving each plant a little piece of ground of its own, upon which it can devote its strength to the glory of blooming instead of en-

\begin{abstract}
Practically all Peonies described below are varieties of the Cbinese Peony, Pzonia albiflora. To aid our customers in making tbeir selections we bave inserted the rating ascribed to tbese varieties by tbe members of the American Peony rieties by the members of the American Peony
Society. These ratings are based on a scale of $I$ Society. These ratings are based on a scale of $I$
to $t o$, indicating the relative value of the variety to 10 , indicating
\end{abstract}

Albatre. The correct name of this variety is Avalanche, which see.

Albert Crousse. 8.6. A large, double, Iateflowering variety of light rose-pink with a creamy, richly tinted flesh-pink center. 75 cts. each, $\$ 7.50$ for 12 .

Avalanche. 8.7. Large; double; midseason. Flowers white and waxy, with a faint pink, rose-like center, lightly touched with crimson. 75 cts. each, $\$ 7.50$ for 12 .

Baroness Schroeder. 9.0. Very large; double; midseason. Pale flesh-white, tinted with crean and frequently shaded pale pink. Very fragrant. One of the very finest Peonies and cheap enough to be planted liberally. $\$ 1.50$ each.

Couronne D'Or, 8.1. Large, Iate-flowering, very double blooms of evenly rounded white petals illumined in the center by a ring of yellow stamens and tipped with crimson. Strong, pungent fragrance. A very dependable late white variety. 60 cts. each, $\$ 6$ for 12 .

Duc de Wellington. 7.8. A moderately Iarge flower with broad, pure white outer petals surrounding a compact ball-like center of pale sulphur-white. An excellent cut-flower. 50 cts. each, $\$ 5$ for 12 .

Duchesse de Nemours. 8.1. A large, earlyflowering, double variety, with cupped, white outer petals and a moderately full center of light canary-yellow, shading to pale cream at the base. Notably fragrant. A dependable and profuseblooming sort which is very popular. 60 cts. each, $\$ 6$ for 12 .

Edouard ANDrE. 7.1. Midseason. Mediumsized flower of rich crimson-maroon, with bright yellow stamens in the center. $\$ 1.50$ each. 
Edulis Superba. 7.6. An old, tried and true variety, largely planted because it blooms so early. Bright old-rose pink, slightly lighter toward the center. One of the most popular and widely known Peonies in the world. $60 \mathrm{cts}$. each, $\$ 6$ for 12 .

EUGENE VERdier. 8.3. A large, Iate-flowering, double bloom of vivid rose-pink, paler in the center, with a creamy yellow base. \$1 each, \$10 for 12 .

Felix Crousse. 8.4. Large; midseason. Brilliant satiny crimson flowers. Generally considered one of the best. $\$ 1$ each, $\$ 10$ for 12 .

Festiva Maxima, 9.3. Very Iarge; double; midseason. Pure white flower with a few crimson flecks in the center. One of the finest Peonies in existence. 75 cts. each, $\$ 7.50$ for 12 .

Germaine Bigot. 8.5. Large, semi-double flowers of light rose-pink, showing golden stamens in the center. A very dependable sort for general use. $\$ 1$ each.

Gismonda. 8.2. A very late, Iarge, double flower of pale creamy pink, with a rose-pink center and strong rose-like fragrance. One of the handsomest of the late pink varieties. \$2 each.

Grover Cleveland. 8.2. Large, double flowers of bright crimson. Valued because of its lateness. $\$ 1.50$ each.

Gubrate. An old-time, unrated dark red variety of interest because of its rarity. $40 \mathrm{cts}$. each, $\$ 4$ for 12 .

Humei. 5.7. A very old variety, introduced in 1810. Double flowers of bright cherry-pink. 50 cts. each, \$5 for 12 .

JaMes Kelway. 8.7. Blooms very attractive, Ioose, fluffy, of great size, pale pink at frist, becoming white with a slight yellow suffusion as it ages. $\$ 1$ each, $\$ 10$ for 12 .

Karl Rosenfield. 8.8. Good clear red of excellent form and reliable blooming habit. Many consider it the best red Peony. $\$ 1.50$ each.

LA FrANCE. 9.0. Enormous, perfectly formed blooms with very broad, crisp petals of clear light pink. Remarkably beautiful and impressive. $\$ 4.75$ each.

LA Perle. 8.5. A very dainty and beautiful oldrose pink, with a slightly darker center, flaked red, the whole flower shaded Iavender. One of the most beautiful varieties of its color. $\$ 1$ each.

LA Tendresse. 8.1. Handsome, Iacy, pale lavender flowers, shading to cream and white, sometimes flecked with crimson. $\$ 1.2 \overrightarrow{5}$ each.

Livingstone. 8.1. A large, late variety of old-rose pink, with strong, sweet fragrance. Stems very strong and erect. $\$ 1.25$ each.

LoRd Kitchener. 7.6. Very early, bright red, with broad outer petals enclosing a loose, balllike center. \$1.25 each.

Marguerite Gerard. 8.4. Handsome, double Hlowers of pale flesh-pink, darkening toward the center, and brightened by many yellow stamens. $\$ 1$ each.

Marie Lemoine. 8.5. Considered by fanciers one of the handsomest Peonies grown. Flowers very Iarge, pale lemon-white, strongly suffused with yellow in the center at first and later becomes a pure white globular bloom of exquisite beauty. 75 cts. each, $\$ 7.50$ for 12 .

Marquis C. Lagergren. 7.8. Light cherry-red with darker shadings. $\$ 2$ each.

Mme. Carpentier. An old, unrated pink variety. 50 cts. each, $\$ 5$ for 12 .

MME. Coste. 6.5. An attractive old bright pink variety with a sulphur-yellow center. $50 \mathrm{cts}$. each, $\$ 5$ for 12 . gaging in mortal combat all year long with thieving wceds and grass.

An ideal place for a Peony to display its gorgeous flowers against an appropriate background is in front of a clump of shrubs, allowing thcm sufficient room for their roots to forage deep, and a large measure of sunshine overhead. The perennial border, where other flowers are grown, may be devoted, in part, to Peonies, keeping them well to the front to insure that they will not be overgrown by hardy asters, or other tall, late-flowering plants. In a long border by a walk or drive, not in a solid line-that becomes wearisome after they are out of flower-but in irregularly spaced clumps, interspersed with later-flowering plants, Peonies are magnificent.

It is very bad to plant solid patches of them in rows across the garden, like potatoes. This is an almost universal practice among Peony fanciers whose enthusiasm outruns their good taste, and among those who grow Peonies only to win prizes at exhibitions. The effect of a dozen good Peonies properly placed in a garden is much more handsome than that of several hundred in such a massed planting. Consequently, it pays to devote careful thought to placing them where they will do the most good.

Not long since we saw a magnificent planting of Peonies on a terraced hillside, so spaced that each row of plants was higher than the row in front of it, with ample room for several people to walk between the rows. There was none of the crowded, mass

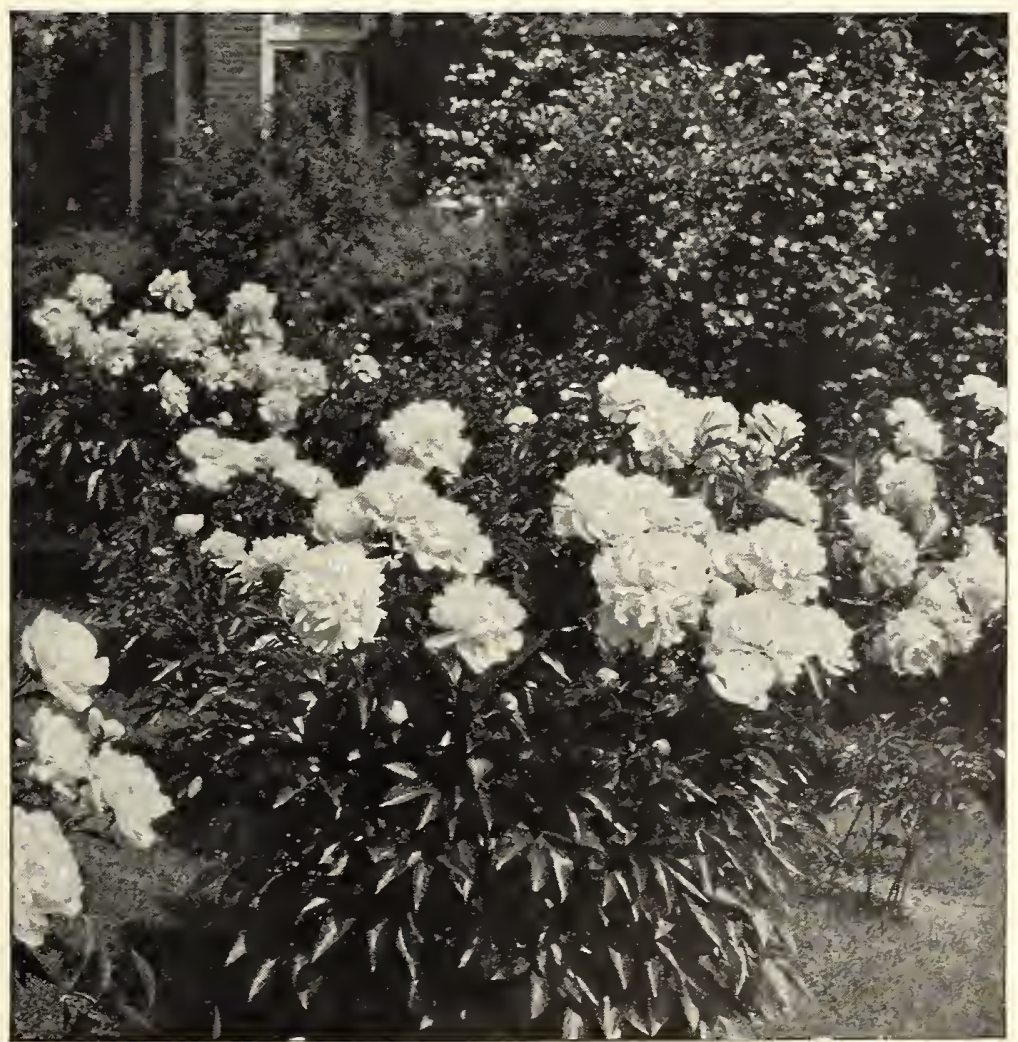

A good plant of Mons. Jules Elie - otber varieties in background 35 
effect there, and the absence of auxiliary plants was not apparent. This planting was in a nursery devoted to Peonies alone; in a private garden it could have been much improved by interplanting the Peonies with delphiniums, hardy phloxes, asters, and, perhaps, chrysanthemums, to provide interest and color when the Peonies were out of flower.

Peonies like rich soil, but be sure there is no fresh manure in it. Fresh manure in contact with Peony roots will cause the plants to become sick and fail to bloom. The ground should be deeply prepared and fertilized in advance, doing a generous job of it, because Peonies are almost as permanent as a house and need never be moved. They like lots of sunlight and need about three feet of open ground all about them after they become established. The first season they should be protected from freezing a little to prevent them from being heaved out of the ground, but afterward they are best without litter or any covering which might harbor disease.

In planting Peonies, be careful not to bury them too deep. The eyes should be just under the surface when the soil has thoroughly settled. This means that they should be about two inches deep when planted in newly made beds to allow for subsequent settling.

They are remarkably free from insect and fungus troubles. Very seldom is it necessary to spray them or worry about them at all. Keep them cultivated and fertilized with bone-meal annually and they will become finer and frner year after year.

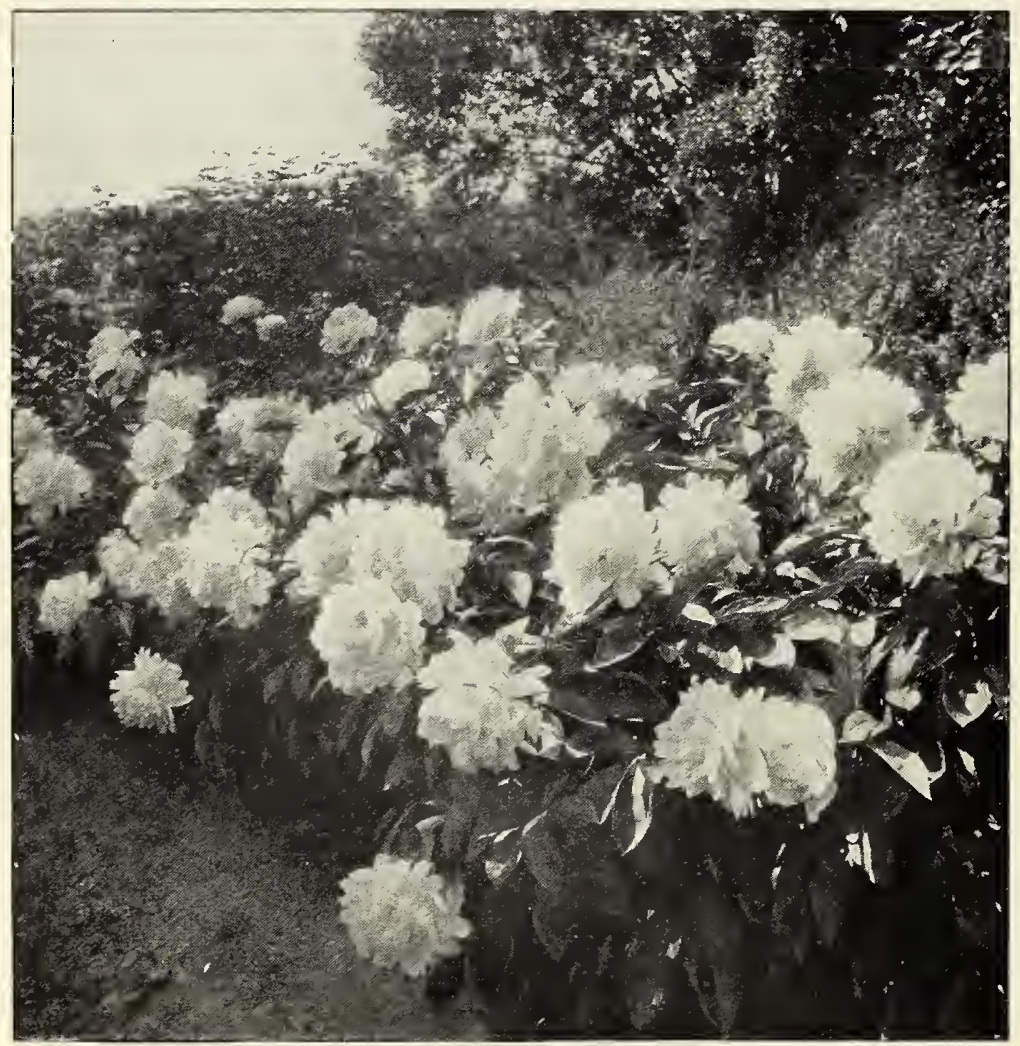

A border of Festiva Maxima in front of shrubs
Mlie. Leonie Calot. 8.1. Medium size, double flowers of rich flesh-pink, very much frilled and ruffled. Blooms a little Iater than most and is deliciously fragrant. $\$ 1$ each.

Mme. Crousse. 7.9. Very large, handsome flowers of pure white, tipped with carmine in the center. 75 cts. each, $\$ 7.50$ for 12 .

Mme. Ducel. 7.9. Medium-sized, extremely compact blooms with large outer petals enclosing a ball-like center, and of a very soft silvery pink throughout. Much like Mons. Jules Elie, only smaller. 75 cts. each, $\$ 7.50$ for 12 .

Mme. Emile Galle. 8.5. A favorite variety because of its delicate color and texture. Large, double flowers of very light rose-pink, translucent and frrm. 75 cts. each, $\$ 7.50$ for 12 .

Mme. Emile Lemoine. 8.9. Large, double, creamy white flowers with a faint flush of tiny pink dots. $\$ 1$ each.

Mme. Jules Dessert. 9.4. One of the very best. Large, double flowers of smooth flesh-white with a faint yellow flush in the center. $\$ 3.50$ each.

Mons. Jules Elie. 9.2. A most gorgeous Peony. Large, compact blooms, with broad outer petals surrounding an immense dome-like center. Color is peculiar, silvery pink most difficult to describe. $\$ 1$ each.

Mons. Krelage. 7.7. A dark purplish red, semidouble flower illumined at the center with bright yellow stamens. 75 cts. each, $\$ 7.50$ for 12 .

Old Double Crimson. This is a very earlyflowering brilliant red variety belonging to the Pxonia officinalis tribe which used to be common in all old-fashioned gardens. \$1 each.

Pierre Duchartre. 8.2. An excellent ball-shape flower of dull, old-rose-pink covered with a silvery sheen. $\$ 1.50$ each.

President Taft. Correct name of this variety is Reine Hortense, which see.

Prince Prosper d'Arensberg. A late-flowering Peony with extra-large dark wine-red blooms. 50 cts. each, $\$ 5$ for 12 .

Reine Hortense. 8.7. Magnificent, extremely double, very large flowers of bright rose-pink, with crisp, fluffy petals notched and silvered at the tips and occasionally flecked with crimson in the center. Occasionally called President Taft. $\$ 1.50$ each.

Sarah Bernhardt. 9.0. A gorgeous dark rosepink flower edged a trifle lighter. Very double and very late. $\$ 1.50$ each.

Solange. 9.7. One of the most famous Peonies in the world. Compact, globular flowers of rich cream-white, deeply suffused with buff and pale salmon-pink. Unique in color and of exquisite beauty. $\$ 3.50$ each.

SUzETTE. 8.2. A picturesque, fluffy flower of very bright rose-pink, brightened by numerous yellow stamens. Very decorative in the garden. $\$ 2.50$ each.

TRIOMPHE DE L'EXPOSITION DE LIIIE. 7.8. Large, handsome flowers of soft flesh-pink sprinkled al over with deeper pink dots. An old favorite and very reliable bloomer. 75 cts. each, $\$ 7.50$ for 12 .

Victolre de la MARne. 8.2. Very large, midseason flowers of rather light purplish red. Striking because of its enormous size and showy color. $\$ 4.50$ each.

\section{SPECIAL OFFER OF PEONIES}

Ten named double varieties, our selection, in lots of $10, \$ 5$; lots of $20, \$ 9$; lots of $50, \$ 20$ 


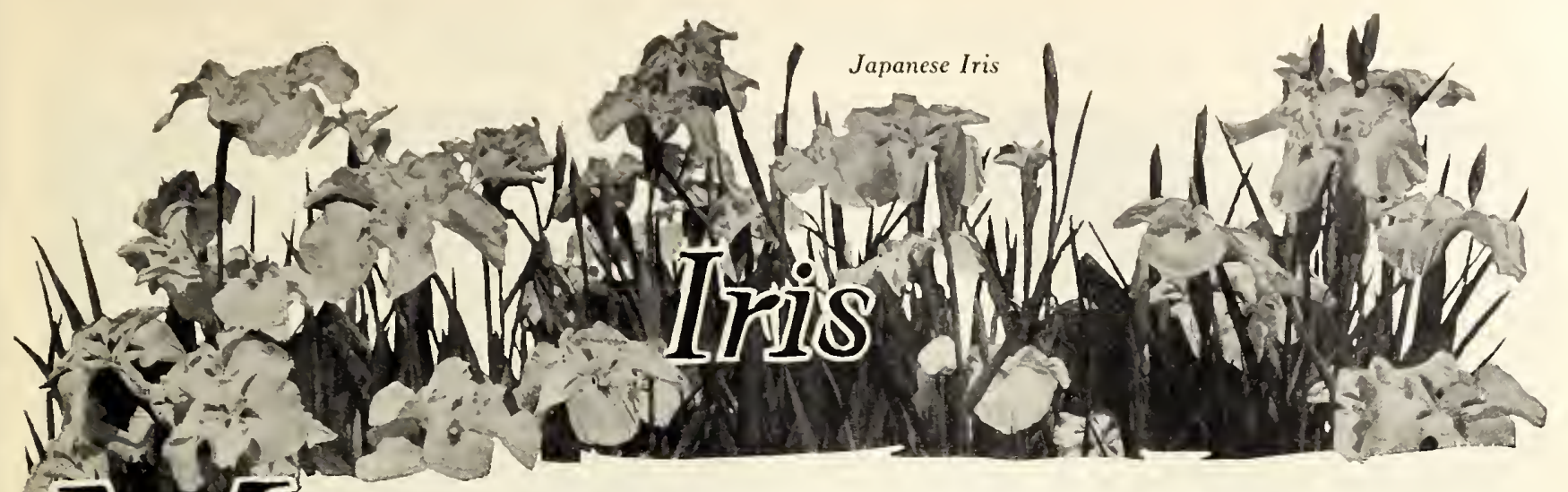

EN and women looking for easy flowers to grow, find the greatest opportunity to obtain the largest amount of floral beauty for the least amount of effort by growing Irises. They thrive under neglect which would kill a Rose in two weeks and upon ground which would starve a Peony to a shadow. The most inhospitable soil contents them, and any location which is drained and sunny. But only a lazy gardener will treat his Irises so, for, like everything else, they enjoy liberal treatment and repay it.

And what a repayment that is! From April, when the first dwarfs poke their bonnets just above the ground, through May and June, when the TaII

\section{Tall Bearded Group}

This group is characterized by three large, erect petals known as the standards, and three more or less drooping petals usually of contrasting color, called the falls. At the base of the falls is a brush-like crest or beard, usually brilliantly colored. The numbers are the rating given by the American Iris Society on the standard of 10 for perfection.

Field-grown plants, 25 cts. each, $\$ 2.50$ for $12, \$ 15$ per 100, except where noted

Alcazar. 8.9. Standards light blue-violet; falls brilliant purple, with bronze veins. Early, large, and very striking.

Ambassadeur. 9.4. Standards smoky Iavender; falls bright purple; orange beard. One of the tallest and largest. $\$ 1$ each, $\$ 10$ for 12 .

AUREA. 7.4. Soft yellow throughout, faintly veined; brownish orange beard. The most popular yellow Iris. $\$ 3$ for $12, \$ 20$ per 100 .

Ballerine. 9.4. Standards pale blue; falls slightly darker; lemon-yellow beard. Tall stems and large, exquisitely proportioned flowers. $\$ 1$ each.

C. WEDGE. Standards gray; falls plum-color, edged white.

Cecile Minturn. Standards light pinkish purple; falls slightly darker; beard yellow. Tall, graceful stems and medium-sized blooms of elegant form. 60 cts. each, $\$ 6$ for 12 .

Cluny. 8.6. Standards light Iavender; falls darker, shaded blue. Tall stems and large flowers. $60 \mathrm{cts}$. each, $\$ 6$ for 12 .

FAIRY. 8.0. Standards and falls white with a blue suffusion at the base. Tall and early. 50 cts. each, $\$ 5$ for 12 .

Florentina. 7.6. Standards and falls creamy white, faintly flushed with Iavender; fragrant and early.

Florentina Purpurea. Standards blue; falls velvety purple; bright yellow beard. Early and very attractive.

Gracchus. 6.1. Standards light yellow; falls brownish crimson with purple markings. Early.
Bearded Irises sway in elegance upon their Iofty stems, until the Japs bring the season to a close in July like the triumphant finale of some great color symphony-three months at least! The tulips blaze and go out, peonies blush and fade, the rose runs riot and grows sober, but through it all the Irises maintain the organ-point which unifres and harmonizes the wild, mad music of spring in every garden.

AIl flowers which enjoy world-wide popularity and have been grown from immemorial time are broken up into numerous families and a great many varieties. So it is with the Iris, which we classify broadly in three distinct groups, namely, the Tall Bearded, the Japanese, and Others.

In this country, we favor the Tall Bearded, a section of robust growth whose tall stems are crowned with glorious flowers of all the colors of the rainbow except true pink and red. They begin to bloom in May, continue through June well into the blooming-time of the Japanese section.

Irises owe their present popularity to the Tall Bearded section. It comprises what we consider the most beautiful of the race, yet demands the least of the gardener. Once planted they take care of themselves almost indefinitely. In those gardens which are subject to long, dry, hot spells which cause disaster among less adaptable plants, they are especially satisfactory.

It is hopeless for us to try to select favorites among the varieties. Tastes differ so much. We favor the pale blue and lavender taller sorts, but people of equally good or better taste frnd yellow, mahogany, smoky purple, and other dull, soft shades even more attractive.

In the list of varieties offered in this book, we have attached the rating given them by the American Iris Society, so that the novice can see the opinion of experts upon them. As a general rule the high rated sorts are best. 


\section{ELLIOTT NURSERY COMPANY + PITTSBURGH, PA.}

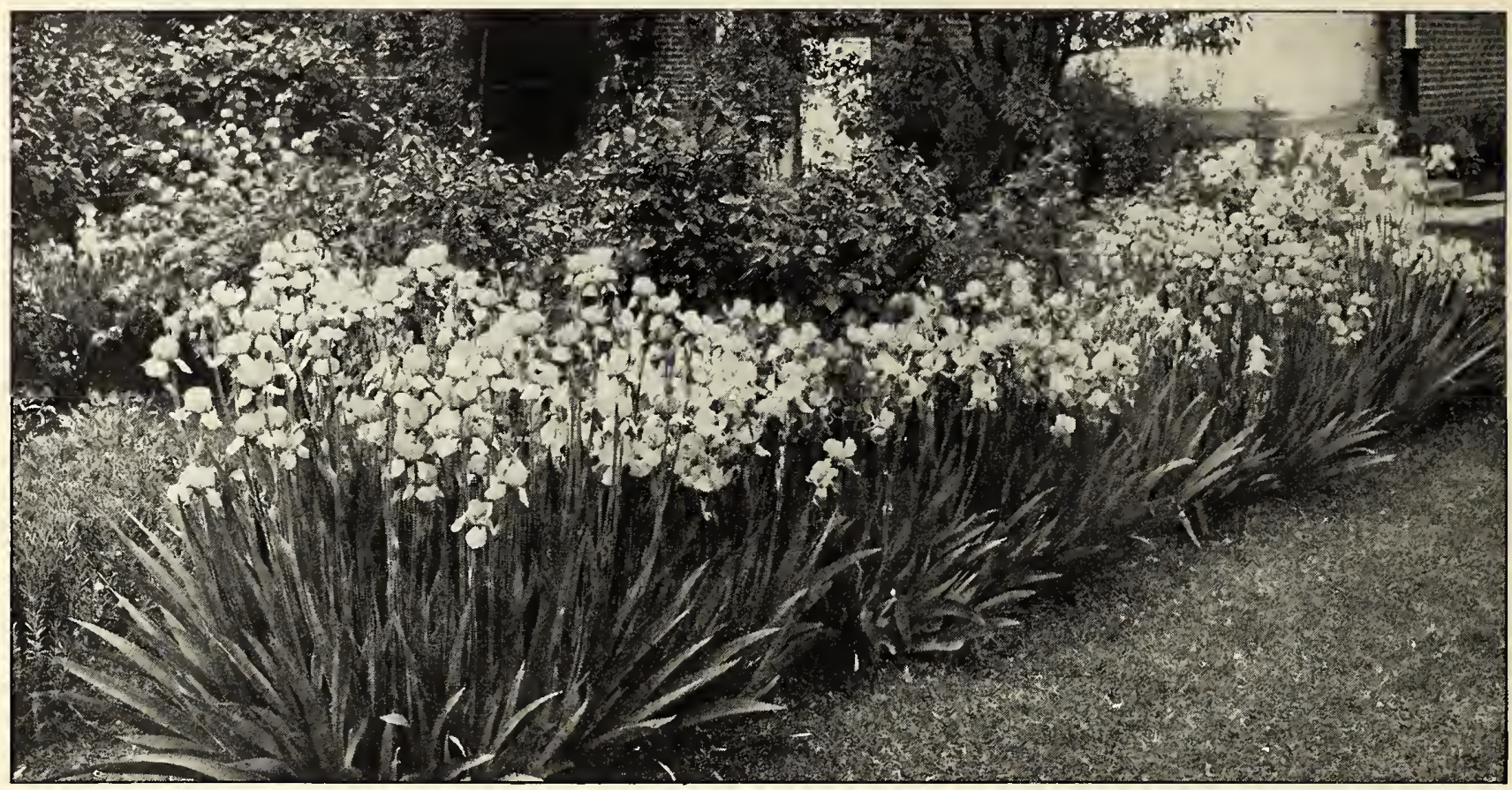

A border of Tall Bearded Irises covered with bloom in June. When the flowers bave faded the foliage will be attractive all season

\section{The Japanese Iris}

Many years ago, the founder of this business, J. Wilkinson Elliott, obtained a duplicate collection of the Irises grown in the Imperial Gardens at Tokio. To that collection, later importations were added, making a most impressive list. But in spite of all the pressure Mr. Elliott and other enthusiasts were able to bring to bear, Japanese Irises never caught on with the American people as they should. The erroneous popular idea that they could only be grown in flooded ground probably had something to do with it.

Many of the varieties we used to catalogue have disappeared for lack of demand. We have found it expedient to discard the unintelligible Japanese names which were impossible to remember, and to give them new ones.

There is a great stirring of interest in Japanese Iris Iately. Reports of new seedlings originating in this country and in France reach us all the time. The whole group will be reorganized and its

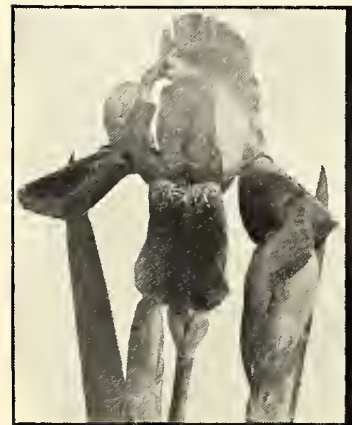

Ambassadeur

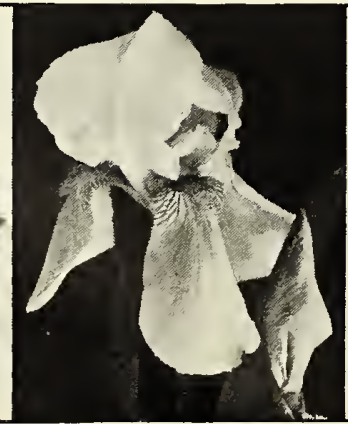

Lord of June

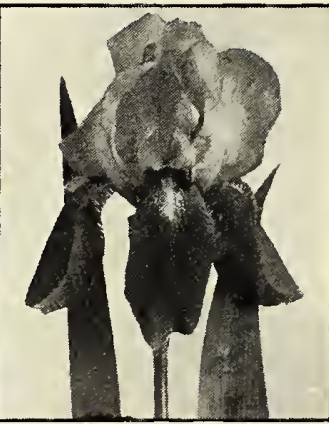

Opera
TALL BEARDED GROUP, continued

Grevin. 8.5. Standards and falls rich red-purple, very tall and beautiful. $50 \mathrm{cts}$. each, $\$ 5$ for 12 .

Her Majesty. 7.3. One of the best pink varieties. 35 cts. each, $\$ 3.50$ for 12 .

IRIS KING. 7.9. Standards Iemon-yellow; falls maroon-red, edged yellow. A fine, brilliantly colored variety. 35 cts. each, $\$ 3.50$ for 12

JEANNE D'ARC. 7.8. Standards and falls white with delicate violet-blue veinings at the edges.

Juniata. 8.1. Standards and falls clear lavenderblue; flowers large and fragrant.

LA Neige. 8.3. Standards and falls white, with a yellow glow; beard orange-yellow. Moderate height. 35 cts. each, $\$ 3.50$ for 12 .

Lent A. Williamson. 9.6. Standards pale violet falls rich purple, with a smoky bloom; beard yellow. Very large. 60 cts. each, $\$ 6$ for 12 .

LoHENGRiN. 8.2. Standards and falls light rosy purple, giving the bloom a pale silvery pink effect in the landscape. $35 \mathrm{cts}$. each, $\$ 3.50$ for 12 .

LORD OF JUNE. 9.1. Standards light lavenderblue and falls darker, stained with brown. Very tall and graceful. \$1 each, \$11 for 12 .

LORELEy. 7.9. Standards yellow; falls purple, edged yellow. Fragrant. A very showy and prolific blooming variety.

Mary Garden. 7.8. Standards pale yellow and Iavender; falls creamy white, dotted with crimson.

Massasort. 7.4. Standards and falls a distinct shade of dull blue.

Medrano 8.5. Standards and falls purple; orange beard; flowers large and in effect bright rosy lilac. 75 cts. each, $\$ 7.50$ for 12 .

Midnight. Standards and falls dark silvery purple, 28 inches high.

Moliere. 8.5. Standards violet; falls darker; veins brown. $60 \mathrm{cts}$. each, $\$ 6$ for 12 . 


\section{I $\quad$ R}

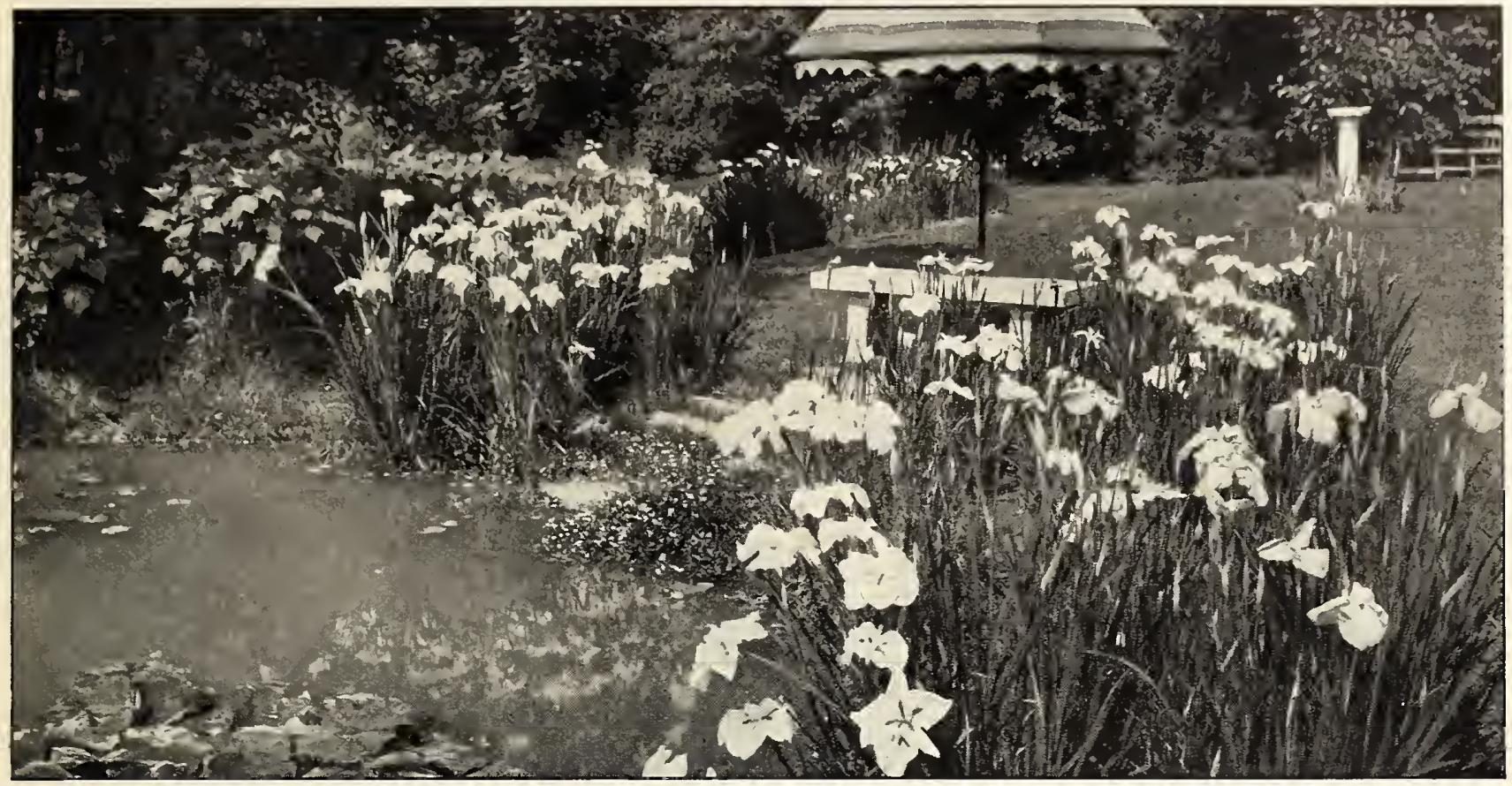

Japanese Irises in tbeir natural setting. Witb a little extra care in watering tbey are equally fine in ordinary sonl

TALL BEARDED GROUP, continued

Monsignor. 8.4. Standards pale blue; falls darker, shaded violet-purple; orange beard. Large and handsome. $35 \mathrm{cts}$. each, $\$ 3.50$ for 12 .

Mother of Pearl. Standards and falls pale bluelavender, shaded with cream. Tall and a profuse bloomer. 75 cts. each, $\$ 7.50$ for 12 .

Niebelungen. 7.3. Standards buff; falls purple, cdged brown. A showy though not brilliant variety. Very profuse in bloom.

Nuef D'Orage. 7.6. Standards pale purple-gray; falls violet. A quietly colored landscape variety.

OPERA. 8.7. Standards purple-red; faIIs violetpurple. A strong, rich color as near to crimson as any Iris. Plant is dwarf. \$1 each.

Oriflamme. 7.8. Standards lavender; falls violet. 50 cts. each, $\$ 5$ for 12

Pallida Dalmatica. 8.8. Standards and falls light Iavender-blue, shaded with silvery blue. Very tall and floriferous. Perhaps most popular Iris in the world. 35 cts. each, $\$ 3.50$ for 12 .

Princess Victoria Louise. 7.2. Standards Iemonyellow; falls reddish purple, bordered cream.

Prospero. Standards lavender; falls dark violetpurple. Strong grower. \$1 each.

Queen Caterina. 9.0. Standards and faIls clear lavender-violet, veined with bronze and illuminated with orange beard. One of the favorite varieties. 75 cts. each, $\$ 7.50$ for 12 .

QueEn of May. 7.4. Standards and falls lilacpink, shaded with brown and tinted with a yellow beard. One of the best pink varieties grown. 35 cts. each, $\$ 3.50$ for 12 .

Rhein Nixe. 8.4. Standards white; falls dark violet, edged lighter. Very showy and popular.

SHERWIN-Wright. 7.6. Standards and falls bright golden yellow. Flowers are small and the plant is rather dwarf. The brightest yellow variety.

Wyomissing. 7.2. Standards cream-white and falls Iilac-rose. 35 cts. each, $\$ 3.50$ for 12 . nomenclature straightened out within the next few years; and when that is done there is no telling but that the Japs will outstrip the present favorites.

Certainly they are easy to grow as weeds, and while they enjoy swamp conditions and do their best in such a location, they have been grown beautifully in ordinary garden soil. We thoroughly recommend that they be planted in rich soil, and that they be watered heavily every day for several weeks before they bloom and while they are in flower. If the ground can be flooded, it will help. At that season they can scarcely be fed too much. The result will be astounding.

As far as magnifrcence and beauty go, there can be no doubt that the Japanese Irises are the most gorgeous of the family. The flowers are flat, often 10 to 12 inches across and imperially rich in coloring. The stems are long and straight and may be cut like bundles of reeds before the top bud opens, and every flower will open in water indoors

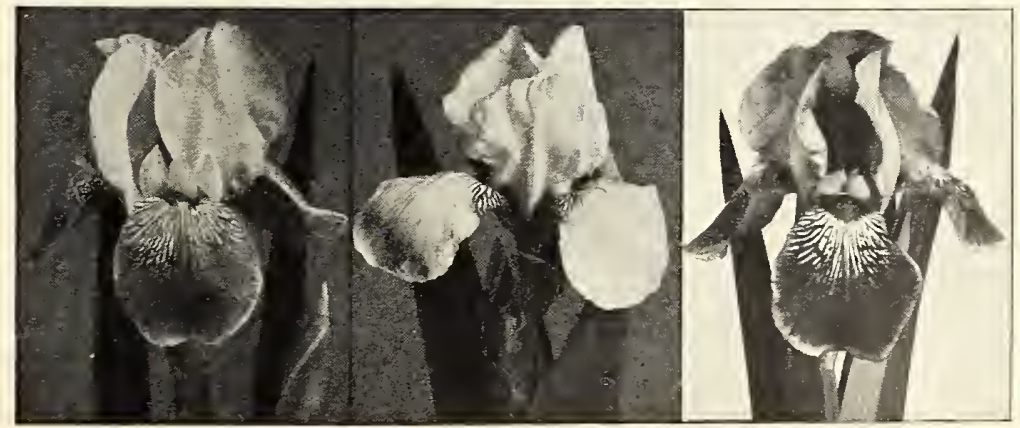

Rbein Nixe

Queen Caterina

Iris King 


\section{Other Irises}

The Intermediate Irises are earlier to flower than the TaII Bearded varieties, but resemble them in most other respects. They are usually about fifteen to eighteen inches high and bloom in early May, continuing well into the blooming season of the Tall Bearded group.

Somewhat similar to the Japanese Iris in their liking for water and in their late flowering season are the tall, graceful Siberians, upon whose lofty stems a perfect cloud of delicately graceful blooms flutter like a host of butterflies. We think the variety known as Perry's Blue is the finest we have seen as yet in height and intensity of true blue color.

Other water-loving types are Iris pseudacorus (Yellow Flag) and $I$. versicolor (common wild Blue Flag). These are adapted to naturalizing in swamps or by stream sides where they are most effective in the mass.

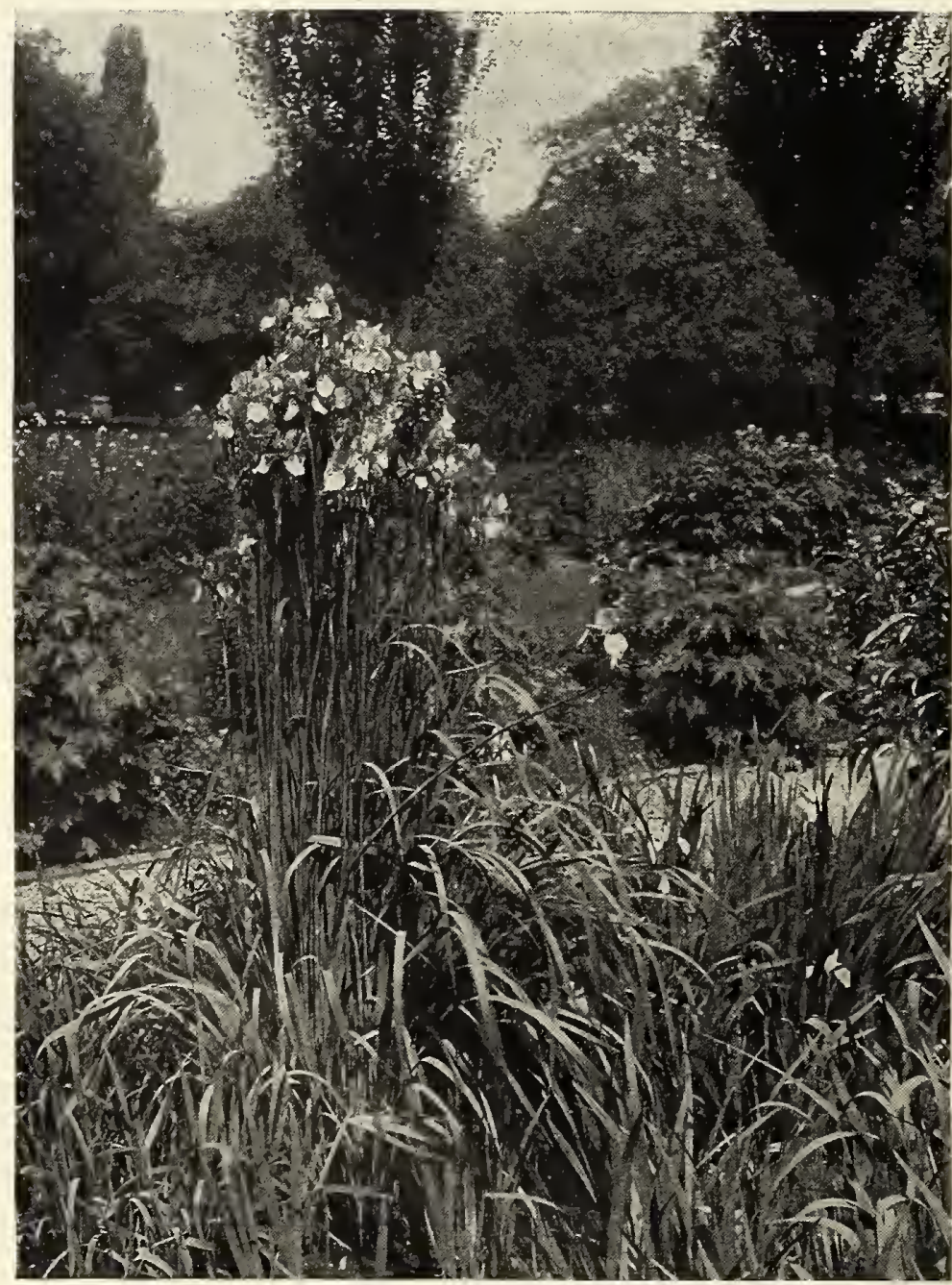

Perry's Blue Siberian Iris is botb stately and graceful when grown in the usual garden soil

\section{Japanese Group}

Ficld-grown plants, 50c. each, $\$ 5$ per doz., except where noted

Azure. Very double; mauve-blue with a darker center.

Catherine Parry. Single. Blue overlaid rosy red.

Doris Childs. Double. Pearl-white, deeply veined plum. 60 cts. each, $\$ 6$ for 12 .

Fascination. Very Iarge, double flower of rich blue. Stems very long and strong.

Gold Bound. Enormous flowers of pure white with orange-gold banded center.

InDo. Single. Rich dark blue, slightly veined.

LA Favorite. White, freely veined bue.

Mr. Hood. Double. Light blue, shaded darker; bright orange center.

Pyramid. Dark violet-blue, slightly veined white. Double and very fine. Very late.

Taineiraku. Rich purple, tipped blue, illuminated with showy yellow blotches in the center. $75 \mathrm{cts}$. each, $\$ 7.50$ for 12 .

Templeton. Light violet, mottled with deep pink and white; nine petals. $\$ 1$ each, $\$ 10$ for 12 .

T.S. WARE. Red-violet, veined white; center white stained with crimson. $60 \mathrm{cts}$. each, $\$ 6$ for 12 .

One each of the Japanese Iris described (12 in all) $\$ 5.75$

Elliott's Fine Mixture of Japanese Iris, $\$ 3$ for 12 , $\$ 20$ per 100

\section{Other Iris}

\section{INTERMEDIATE}

25c. each, $\$ 2.50$ for $12 . \$ 15$ per 100

Canary Bird. Dwarf. Large-flowering pale yellow variety, 7 inches high.

Don Carlos. 8.0. Standards blue; falls reddish.

HALFDAN. 7.1. White with olive markings. Grows 12 to 15 inches high.

InGEBorg. Creamy white; about 2 feet high.

Walmalla. Dark violet; 12 to 20 inches high.

\section{SIBERIAN}

Tall slender plants with rather small flowers in very great abundance.

25c. each. $\$ 2.50$ for $12, \$ 15$ per 100 . except where noted

AlBA. A pure white form of the original Iris sibirica.

Distinction. Small blue standards with white falls, veined with violet.

Orientalis. A species related to the Siberian, with brilliant blue flowers shaded with red.

Orientalis, Snow Queen. Large, ivory-white flowers in great abundance.

Orientalis Superba. Large violet-blue flowers.

Perry's Blue. A new Siberian Iris with extraIarge, bright blue flowers on long, stiff stems. The best of the Siberian tribe in general commerce. $40 \mathrm{cts}$. each, $\$ 4$ for 12 .

\section{NATIVE}

25 cts. each, $\$ 2.50$ for $12, \$ 15$ per 100

Pseudacorus. Tall, glossy plants with broad, brilliant yellow flowers of the Japanese Iris type.

Pseudacorus variegatus. Same except that the foliage is striped.

Versicolor. The common Water Flag. Bright purple-blue flowers. 


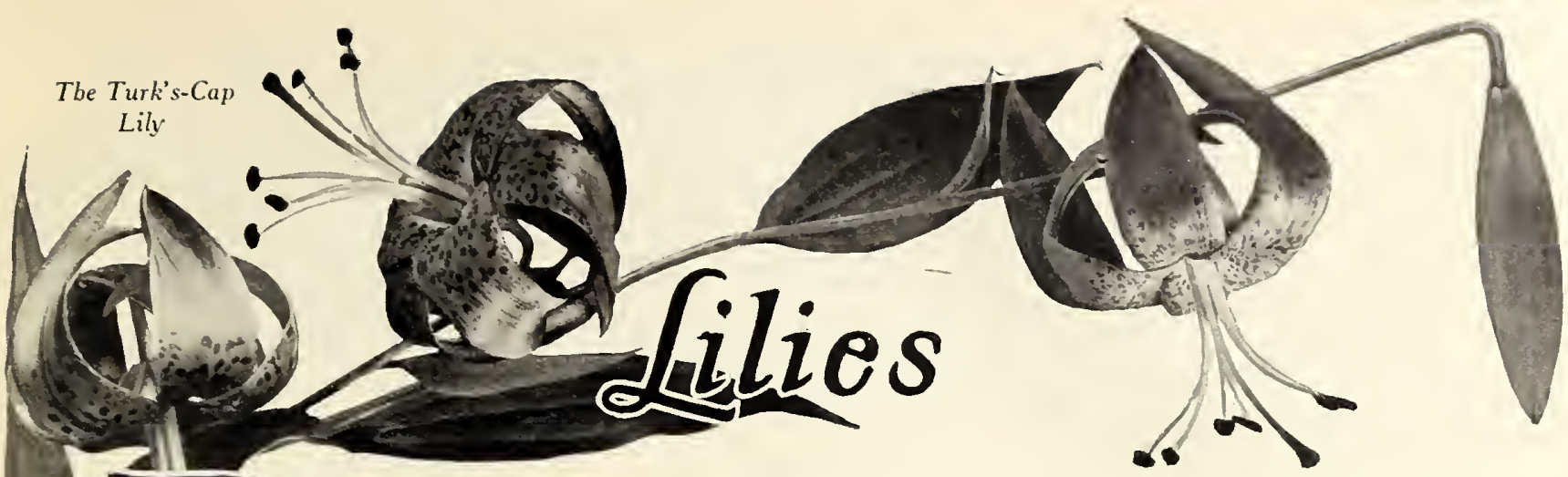

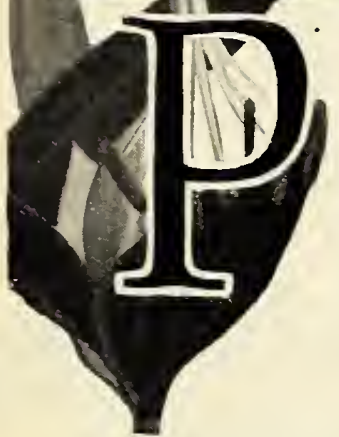

The Lilies mentioned in tbe text and otber beautiful species are offered in tbis column. For certain Perennials called Lilies, consult Index.

\section{Lily • Lilium}

Bermuda EASTER LiLy. Lilium longiflorum. Long, glistening white, trumpet-shaped flowers, borne in the axils of the upper leaves; very fragrant. Plants 3 to 4 feet high. Best for growing in pots. Protect it, if planted outdoors. 6 to 8 -in. bulbs, 30 cts. each, $\$ 3$ for $12, \$ 23$ per $100 ; 7$ to 9 -in. 40 cts. each, $\$ 4$ for $12, \$ 30$ per 100 .

Golden-banded Lily. L. auratum. The most spectacular of all Lilies. It grows 4 to $8 \mathrm{feet} \mathrm{high,}$ bearing clusters of enormous, saucer-like, white blooms with waxen petals curled and waved, spotted with maroon dots and brightened by a shining golden stripe down the middle of each petal. Intensely fragrant. 8 to 9 -in. bulbs, $35 \mathrm{cts}$. each, $\$ 3.50$ for $12, \$ 28$ per $100 ; 9$ to 11 -in. 50 cts. each, $\$ 5$ for 12 , $\$ 40$ per $100 ; 11$ to 13 -in., 65 cts. each, $\$ 6.50$ for 12 .

Hanson's LiLy. L. bansoni. Leafy stalks about 2 feet high, surmounted by drooping clusters of small, thick-petaled, yellow Lilies, covered with tiny brown spots which look as if they were carved from wood or thick opaque wax. $75 \mathrm{cts}$. each, \$7.50 for 12 .

Henry's Lily. L. bentyi. Very tall variety, bearing immense, loose sprays of bright yellow flowers with rich, green centers. Plant it where the ground is shaded by low undergrowth so that its tops may have sunlight. 75 cts. each, $\$ 7.50$ for 12 .

LEONARD JOERG. L. elegans. A special variety of the Red Lily, with bright apricot flowers, most attractively spotted and dotted. $\$ 3$ for $12, \$ 20$ per 100.

Meadow Lriy. L. canadense. Tall, wiry plants, bearing a Iarge, cascading spray of drooping, bell-Iike flowers in shades of red and yellow. Mixed colors, $\$ 2.50$ for $12, \$ 15$ per 100 .

MEADOW LiLY, RED. L. canadense (rubrum). Selected form of the Meadow Lily with flowers in shades of red. $\$ 3$ for $12, \$ 20$ per 100 .

MEAdOW Lily, Yellow. L. canadense (favum). Selection of the native Meadow Lily in different shades of yellow. $\$ 2.50$ for $12, \$ 18$ per 100 . standing their ground along the country roads; but of other Lilies there is a great and doleful lack.

Considering the richness of the Lily family, this is a sorrowful thing. True enough, some Lilies are not easy to keep, but many are, and even the most difficult respond to simple care.

Frankly, Lilies will not grow everywhere. They are wild things which have never been tamed and demand locations to their liking. Remember how the Meadow Lily thrives in the swales of pastures, along the base of railway embankments, in the corners of old rail-fences-always where water is near, and an abundance of lush undergrowth? If you want the Meadow Lily in your garden, you must provide similar conditions. It will not thrive in a hot, dry bed, with the surface of the soil exposed to the summer sun. Did you ever try to dig up one of them? Down, down, down, six inches, eight inches, a foot, often in thick, sticky clay, to find the bulb, or rather cluster of bulbs, resting on a stone or on the woody root of a waterside shrub so that the moisture can drain away from it.

Most Lilies want this deep planting because they make two sets of roots, one below the bulb and one from the stem above it.

In contrast to the wet places where the Meadow Lily grows, we have seen the Wood Lily in great abundance on the south slope of a sand-dune on Cape Cod-growing in full sunshine, with a sparse undercover of wintergreen and beach-grass in the most unattractive and sterile soil on earth. Put the Wood Lily in a shady, moist spot in your garden, and it will die surely; but give it the place it likes, and it will lift its scarlet cups up to the sun as bravely there as in its native haunts.

Lilies are so precious to have that it pays to learn where and how they grow in the wild, and duplicate the conditions for them in the garden. But a few are accommodating enough to make only the usual demands. The gay orange and scarlet Red Lilies of the Elegans type will grow and flourish in almost any ordinary border. 
Tiger Lilies, too. Henry's Lily likes lots of sun and room to shoot up six to ten feet high and spread its great umbrella-like spray of bright golden flowers, shaped like those of the gorgeous Auratum. Hanson's Lily will produce its little stiff yellow blooms in almost any semi-shaded spot.

But almost all the white Lilies, with one exception, need special attention. The exception is the Regal Lily, whose glorious purplestained flowers are waxen white with a glowing golden throat and a fragrance unsurpassed in the entire flowery kingdom. It is a friendly Lily; full sun, semi-shade; dry soil, damp soil; a chink in a wall or a full-fledged garden-bed-all seem equally congenial to it. Plant the bulb about six inches deep, with a little sand below it, and the Regal asks no more.

Not so the glorious Golden-banded Auratum. The books tell us to plant them where their roots will be shaded and their tops in full sun, but experience is very contradictory, so it behooves everyone to try them in many places until the spot they like is found. They are so marvelously beautiful, and they produce so magnificently from the bulb the first year, that there is no reason for being without them every year; but it is pleasant to conquer their difficulties and make them truly happy and at home.

Something the same are the Speciosum Lilies. They are likely to deteriorate rapidly, but their performance is so wonderful the first season that they are worth replanting every spring, the same as tulips and hyacinths; besides, by careful study or by chance, one may hit upon the secret of their success and have them growing on triumphantly year by year.

The lovely Bermudas are the Lilies in the florists' shops at Easter. In the garden, they need a little protection over winter, because they are not entirely hardy; but on the whole it is better to grow them in pots, keeping them in a coldframe or in a cool cellar during the cold weather and planting them out in a protected spot in spring.

\section{LILIES, continued}

Melpomene. Lilium speciosum. A brilliant crimsonpink variety of the Showy Lily. Petals white at the tips, flushed pink and marked with a deep crimson stripe. 7 to 9 -in. bulbs, 35 cts. each, $\$ 3.50$ for $12, \$ 28$ per $100 ; 9$ to 11 -in., 50 cts. each, $\$ 5$ for $12, \$ 40$ per 100 .

Red LiLy. L. elegans. Dwarf, sturdy plants bearing clusters of erect flowers in various shades of red, orange, and yellow, beautifully spotted with darker dots. $\$ 2.50$ for $12, \$ 18$ per 100 .

Regal Lizy. L. regale. Vigorous, wiry plants 2 to 4 feet high, bearing white flowers with yellow throats and purple stains on outside; deliciously fragrant. The easiest white Lily to grow. 5 to 6 -in. bulbs, 50 cts. each, $\$ 5$ for $12, \$ 40$ per 100 ; 6 to 8-in., 65 cts. each, $\$ 6.50$ for $12, \$ 50$ per 100.

Showy LiLy. L. speciosum (rubrum or roseum). Large, pinkish white flowers, beautifully reflexed in the manner of $L$. auratum, dotted throughout with wine-red spots. 7 to 9 -in. bulbs, 35 cts. each, $\$ 3.50$ for $12, \$ 28$ per 100 ; 9 to 11 in., 50 cts. each, $\$ 5$ for $12, \$ 40$ per $100 ; 11$ to 13 in., 60 cts. each, $\$ 6$ for 12 .

Tiger LiLy. L. tigrinum (splendens). An improved form of the brilliant old-fashioned orange and red Tiger Lily. One of the noblest and handsomest of the family. $\$ 2.50$ for $12, \$ 18$ per 100 .

Tiger Lily, Double. L. tigrinum (splendens). A double-flowering form of Tiger Lily, the same in color but has many clustered petals in the center instead of stamens. $\$ 3$ for 12 , $\$ 20$ per 100 .

TuRK's-CAP LiLy. L. superbum. The tallest, finest, and showiest of the native American Lilies. When good will grow 7 to 8 feet high, bearing several hundred scarlet-orange flowers with the petals tightly curled back like a turban. Special offer, $\$ 2.75$ for $12, \$ 20$ per 100 .

White Showy Lily. L. speciosum (album). A pure white variety of $L$. speciosum, without red dots, but occasionally slightly tinted green at the base. The sweetest of this type and not quite as tall as other kinds. 7 to 9 -in. bulbs, 55 cts. each, $\$ 5.50$ for 12 .

Woop LiLy. L. pbiladelpbicum. Dwarf, sturdy plants, bearing erect, showy, orange-scarlet, cupshaped flowers. $\$ 2.50$ for $12, \$ 18$ per 100 .

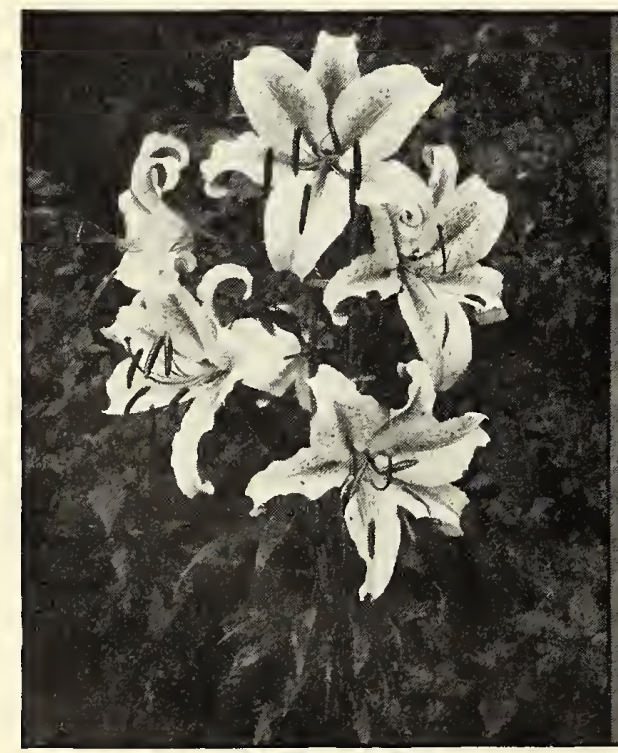

The Golden-banded Lily

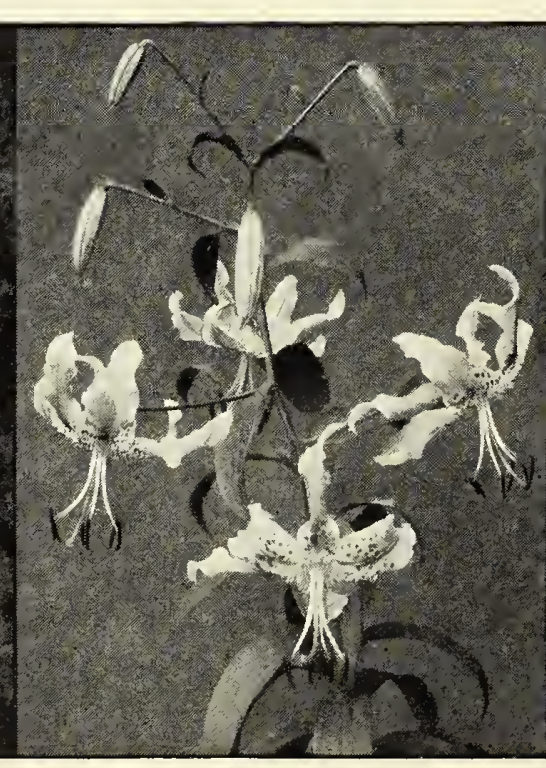

The Sbowy Lily

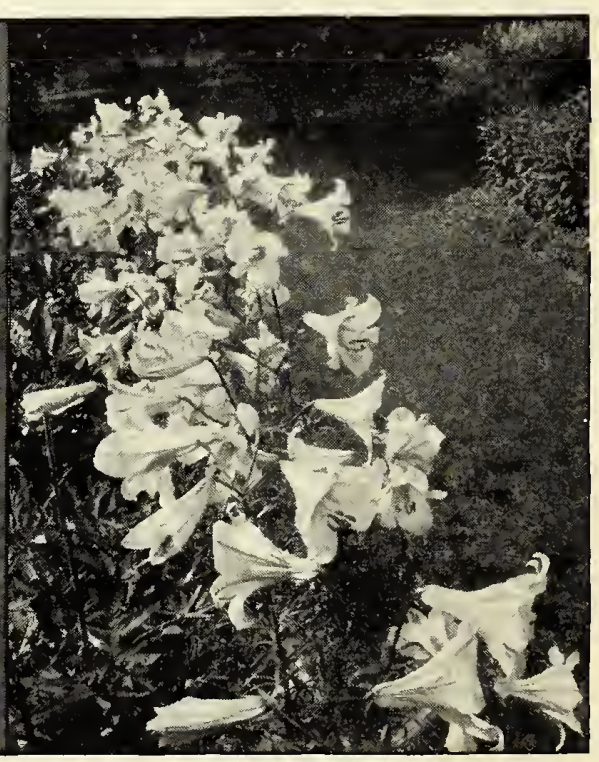

Tbe Regal Lily 



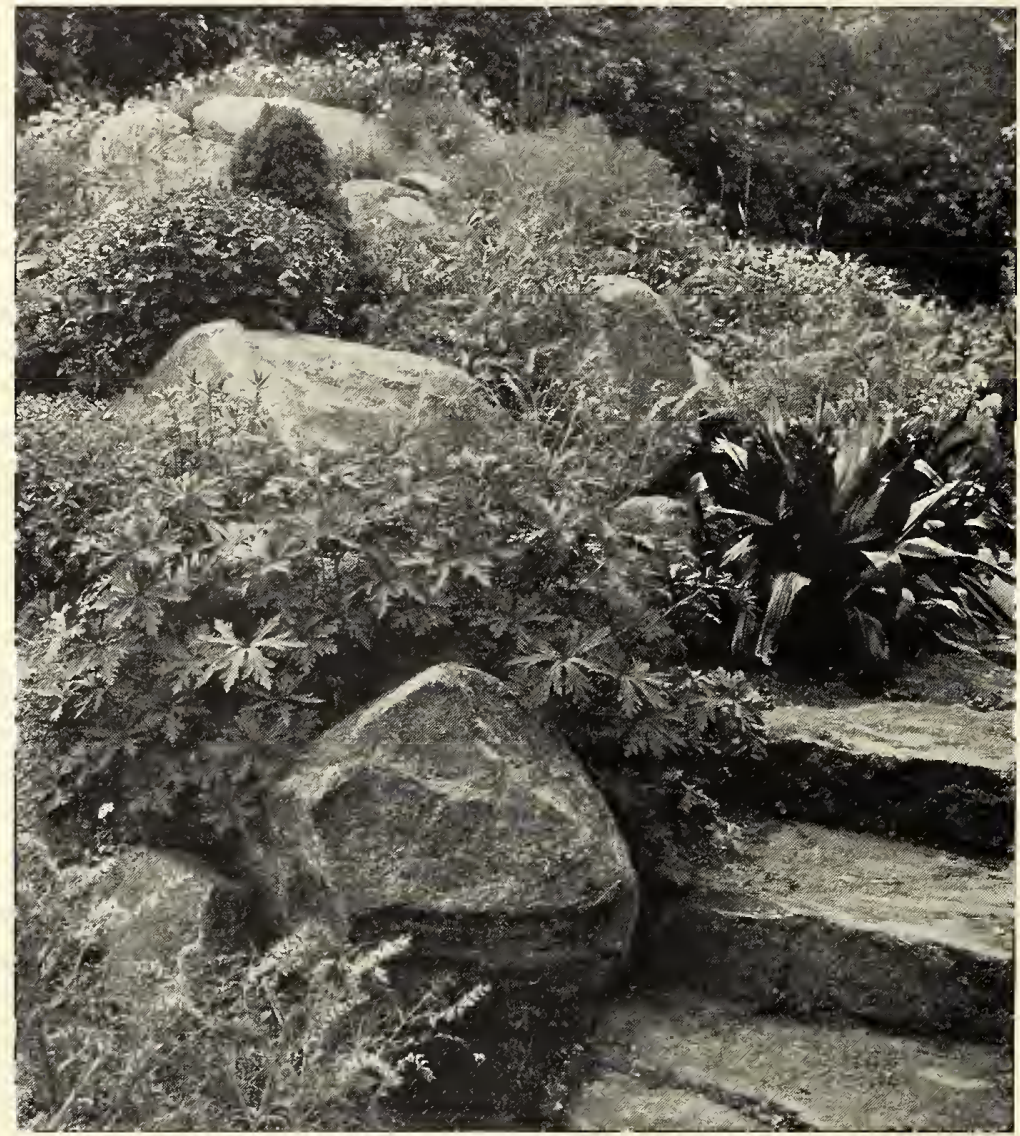

A Rock Garden of distinctly informal type, well furnisbed with plants of many varieties

less than a hundred square feet, yet it held scores of delightful plants.

But even the most ambitious rock garden may fail if there is lack of imagination in choosing the plants. Sedums and phloxes are very pretty in moderation, and they are almost certain to grow among the rocks; but they do spread, and they do get tiresome. The enthusiastic gardener will not content himself with such material when he knows of the hosts of charming little bellflowers

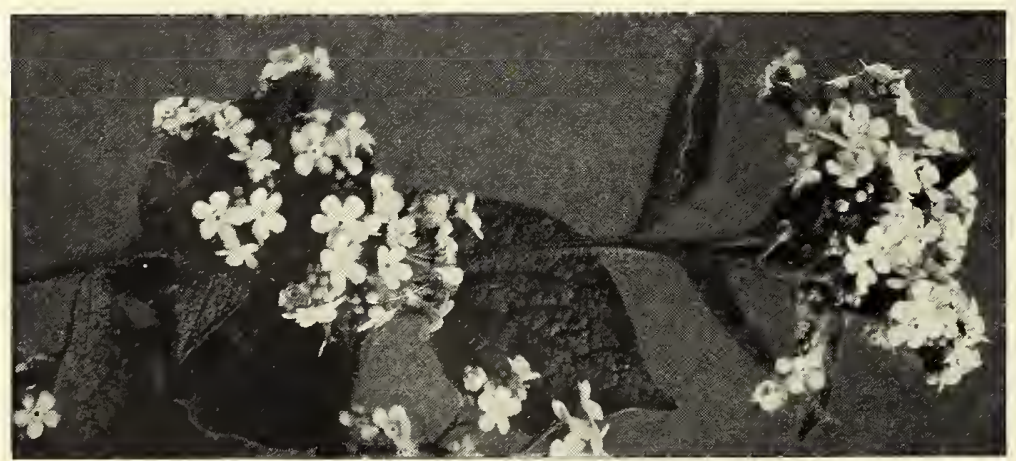

The Forget-me-not Anchusa is an exquisite rock plant and the flowers are good for cutting

\section{Baneberry - Actæa}

Red Baneberry. Actæa rubra. A rough, leafy plant with clusters of inconspicuous white flowers followed by brilliant red berries in summer and autumn. Shade. 18 to 24 in.

White Baneberry. A. alba. Similar, except that the berries are white tipped purple, on thick red stems. Very showy. Shade. Summer and autumn. 18 in.

\section{Bellflower - Campanula}

Carpathian Harebell. Campanula carpatica. Trailing plants with bright green foliage, studded with erect, steel-blue bells an inch across. Full sun. July-September. 6 to 8 in.

Carpathian Harebell, White. C. carpatica. A very charming white variety, indispensable in the rockery. FuIl sun. July-September. 6 to 8 in.

\section{Blue Bells • Mertensia}

Virginia Blue Bells. Mertensia virginica. Lush, leafy plants with drooping clusters of delicate skyblue bells, often tinged pink. Moist shade. April. 18 to $24 \mathrm{in}$.

Bugle • Ajuga

Carpet Bugle. Ajuga reptans. A dense, creeping, leafy plant with dull blue flowers. Sun. May, June. 2 to 6 in.

Callirhoe - Callirhoe

Poppy-Mallow. Callirboe involucrata. Hairy plants with attractive leaves and bright cherryred flowers, like little poppies. Full sun. JuneSeptember. 12 to 18 in. 30 cts. each, $\$ 3$ for 12 , $\$ 20$ per 100 .

\section{Candytuft - Iberis}

Evergreen Candytuft. Iberis sempervirens. Broad, wiry mats of dark, evergreen foliage, hidden under a mass of white bloom in May. Indispensable rock plant. Sun. $1 \mathrm{ft}$.

Rock Candytuft. I. saxatilis corifolia. Fine little tufted evergreen studded with showy clusters of white flowers. Sun. May. 6 to 8 in.

Cardinal Flower - Lobelia

Cardinal Flower. Lobelia cardinalis. Sturdy, erect stalks tipped with glowing scarlet flowers in spikes. Moist places, semi-shade or sun. July, August. 2 to $3 \mathrm{ft}$.

\section{Centaurea - Centaurea}

Mountain Bluet. Centaurea montana. Attractive, downy plants with very large, blue flowers like giant cornflowers. Sun. May-September. 12 to 18 in.

WhIre. C. montana (alba). The same, with white flowers. Both are valuable for their continuous bloom. Sun. May-September. 12 to 18 in.

\section{Cerastium • Cerastium}

Snow-In-Summer. Cerastium biebersteini. A creeping, mat-like plant with silvery white leaves, and starry, white flowers. Sun. May, June. 6 in.

Coronilla - Coronilla

Crown Vetch. Coronilla varia. A trailing plant with clusters of pinkish white, pea-like flowers. Dry; sun. June-October. 1 to $2 \mathrm{ft}$.

All plants on this page, except where noted are $25 \mathrm{cts}$. each. $\$ 2.50$ for $12, \$ 18$ per 100 . Six of one kind sold at the 12 rate. 50 of one kind at the 100 rate. 


\section{Columbine - Aquilegia}

Rocky Mountain. Aquilegia crerulea. Loveliest of all, with pale blue flowers and long, graceful spurs. Sun or half shade. June. 18 in. 30 cts. each, $\$ 3$ for $12, \$ 20$ per 100 .

SUPERBA. A. alpina. Beautiful foliage and Iarge, blue and white flowers with curled-in spurs. Sun. May, June. $1 \mathrm{ft}$.

Wild ReD. A. canadensis. Gay, sparkling, vivid red and yellow flowers, always fluttering in the breeze, A most useful rock plant widely used by Mother Nature herself. Sun or shade March April. 8 to 12 in.

Yellow Rocky Mountain. A. cærulea (lutea). A hybrid form with pale yellow flowers. Very charming. Sun or half shade. June. $18 \mathrm{in.}$

Otber Columbines described in Hardy Garden Section, page 55

\section{Daisy (English) • Bellis}

LoNGFEllow. Bellis perennis. Rosettes of leaves with double, bright rosy red flowers 1 inch or more across. Sun. March-June. 5 to 6 in. $\$ 2$ for 12 , $\$ 12$ per 100 .

Snowball. $B$. perennis. Same, with pure white flowers. Sun. March-June. 5 to 6 in. $\$ 2$ for 12 , $\$ 12$ per 100 .

\section{Dragonhead · Dracocephalum}

Siberian. Dracocepbalum ruyscbiana. Bushy plants with deep purple flowers an inch across. Best in moist shade. June, July. $2 \mathrm{ft} .30 \mathrm{cts}$. each, $\$ 3$ for $12, \$ 20$ per 100 .

\section{Dropwort • Filipendula}

Dropwort. Filipendula bexapetala. Low, handsome foliage, with foamy flowers on stems 2 feet high. Sun. June, July.

Dropwort, Double. F. bexapetala ( $f$. pl.). The same with even denser heads of very double flowers. Sun. June, July. $2 \mathrm{ft}$.

\section{Evening Primrose · Enothera}

Ozark Sundrops. GEnotbera missouriensis. A lower variety than $C E$. fruticosa, with very broad, bright yellow flowers. Sun. June, July, $1 \mathrm{ft}$. 30 cts. each, $\$ 3$ for $12, \$ 20$ per 100 .

Young's Sundrops. $C$. fruticosa (youngi). Stiffstalked plants crowned with bright yellow flowers which close at night. Sun. June, July. 1 to $2 \mathrm{ft}$.

Ferns - Polypodiaceæ

Christmas Fern. Polysticbum acrosticboides. Stiff, leathery fronds, in an erect whorl; stay green all winter. Half shade. $1 \mathrm{ft}$.

Cinnamon Fern. Osmunda cinnamomea. Bold, broad fronds, arranged in a great funnel-like whorl, with brown, fertile fronds in the middle. Half shade. 2 to $3 \mathrm{ft}$.

Common Woodsia. Woodsia obtusa. Clustered, feathery fronds 6 inches to a foot long. A true rock plant, needing shade and moisture.

Goldie's Fern. Dryopteris goldieana. A giant Fern with fronds 12 to 18 inches wide, and 3 to 4 feet long. Semi-shade, or moist soil in full sun.

Hay-scented Fern. Dennstædtia punctilobula. Finely cut leaves, very broad at the base, with pleasant fragrance when dry. Half shade; light soil.

INTERRUPTEd FERN. Osmunda claytoniana. A noble Fern for moist, peaty soil in sun or half shade. Ordinarily 2 to 3 feet high.

All plants on this page, except where noted, are $25 \mathrm{cts}$. each, $\$ 2.50$ for $12, \$ 18$ per 100 . Six of a kind sold at the 12 rate; 50 of one kind at the 100 rate.

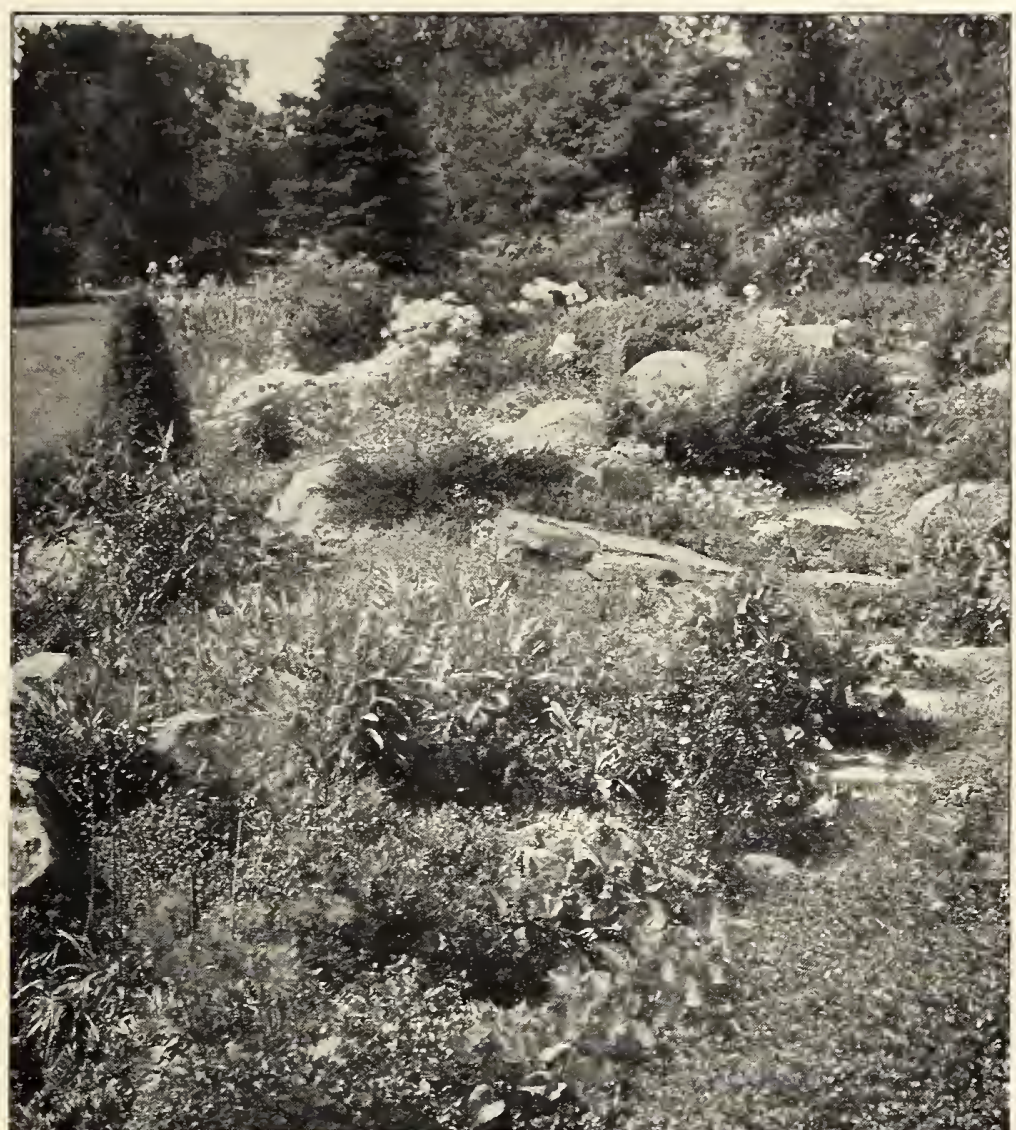

An elaborate Rock Garden full of bundreds of cbarming little plants, deligbtful in its general effect

(campanulas), fragrant fringed pinks (dianthus), gay little columbines (aquilegias), and the hosts of ferns and other jewel-like plants of many families which thrive in such a garden.

Authorities differ as to just what constitutes a rock plant. Some maintain that only those which will grow nowhere else should be used in rock gardens, but the more sensible and more human view is that any plant which grows well and looks well among the rocks is a plant to grow there. This leaves the selection to be made from plants of endless variety, so long as appropriateness of habit and adaptability to rock garden conditions are considered.

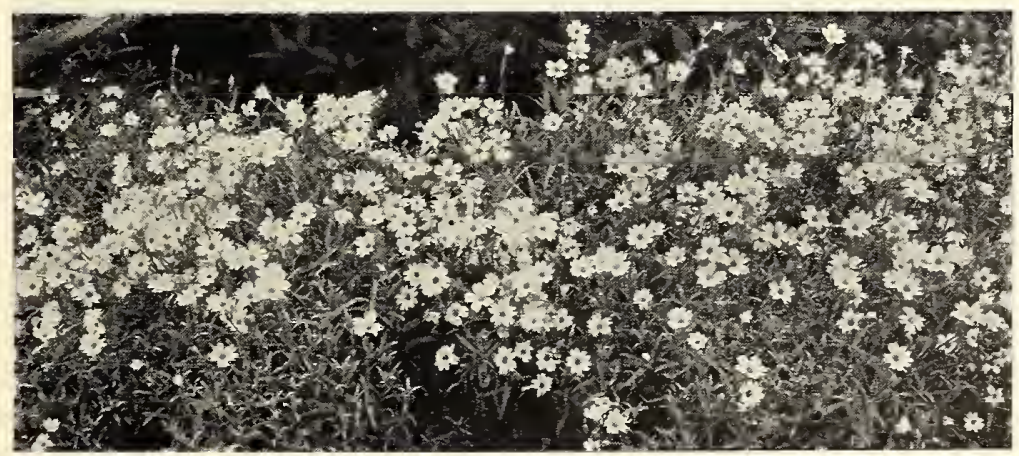

Snow-in-Summer makes a cbarming bank of flowers against a rock or as an edging 45 


\section{ELLIOTT NURSERY COMPANY + PITTSBURGH, PA.}

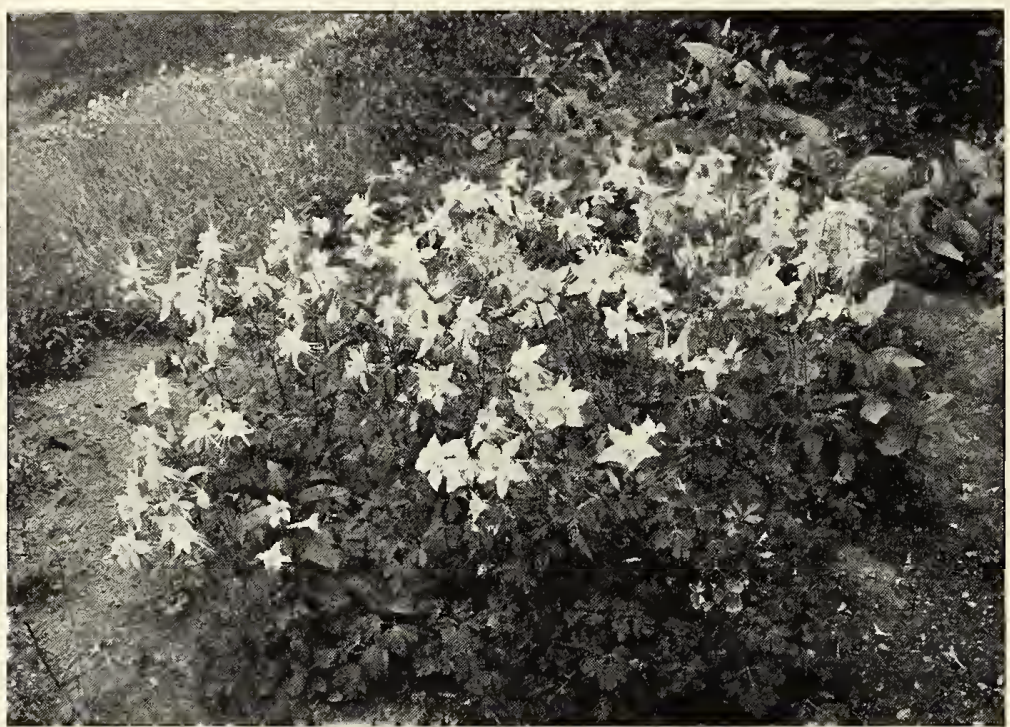

The charming Rocky Mountain Columbine at bome in the rock garden

For large rock gardens, dwarf forms of the evergreens, such as the Mugho Pine, the Savin Juniper, the Canadian Yew, and others will make picturesque backgrounds. Certain of the azaleas, the garland flower (daphne), and almost all of the smaller flowering shrubs are both suitable and desirable. From the list of perennial plants commonly grown, those of dwarf, bushy, trailing, or matting habit may be chosen; and a very fine collection of rock plants can thus be made without going into the territory of the specialist at all. In fact, we know of no way of winning more delight from a

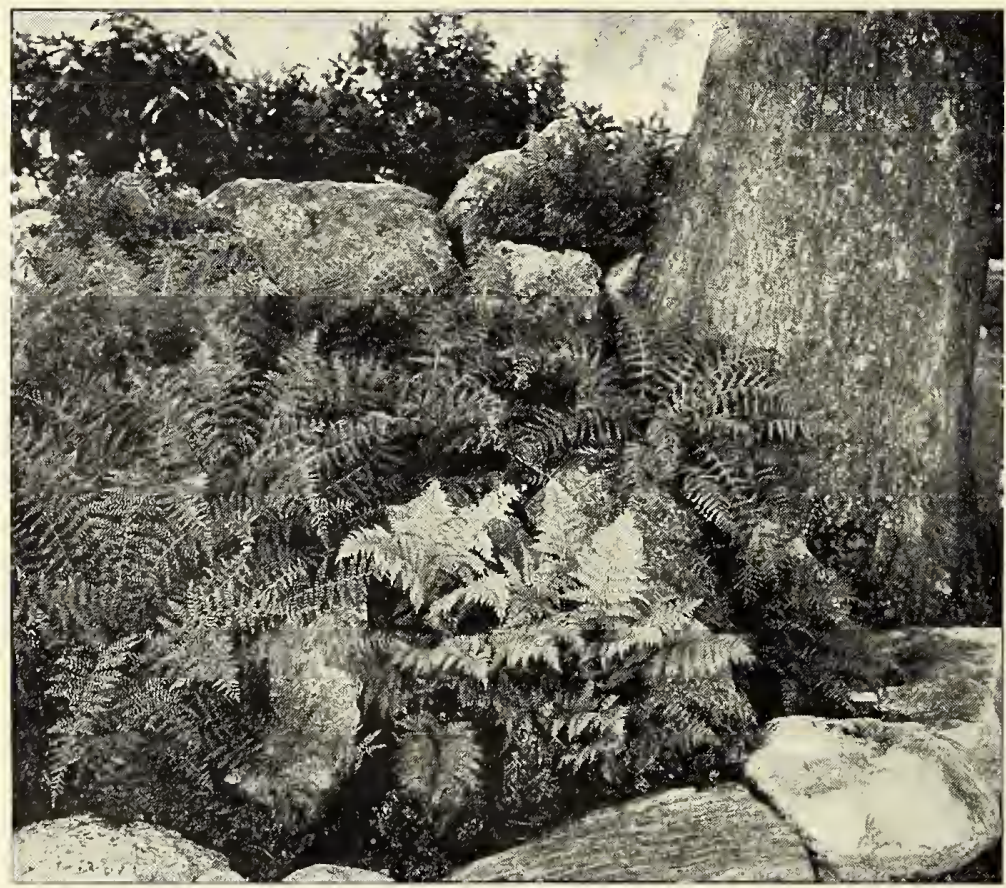

Few things are more luxuriant and impressive in the rockery tban Ferns
FERNS, continued

LADY FERN. Atbyrium filixfemina. Very graceful; 2 to 3 feet high and extremely variable. Moist shade.

LeATHER FERN. Dryopteris marginalis. Very common wild Fern growing in rocky woods Semi-shade, rather dry.

Maidenhair Fern. Adiantum pedatum. Flat fronds held horizontally; very airy and delicate. Half-dry shade. The daintiest of the family. $1 \mathrm{ft}$.

Ostrich Fern. Pteretis nodulosa. One of the handsomest native Ferns. Rich, moist soil, partial shade. 2 to $6 \mathrm{ft}$.

ROYAL FERN, Osmunda regalis. In rich, wet swamps in sun or shade will reach 10 feet. The handsomest and most gorgeous of the Ferns. In moist sockeries, sun or shade. 2 to $3 \mathrm{ft}$.

Fescue - Festuca

Blue Fescue. Festuca glauca. Drooping, ornamental grass with narrow, silvery leaves in tufts. Sun. 6 to 18 in.

Flax • Linum

Perennial Flax. Linum perenne. Slender, bushy plants with gray foliage and brilliant blue flowers open in sunshine. Highly ornamental. Sun. 1 to $2 \mathrm{ft}$.

White Flax. L. perenne (album). The same, with white flowers.

Forget-me-not - Myosotis

TrUe Forget-Me-Not. Myosotis scorpioides (semperflorens). An improved variety for damp, half shade. Bright blue flowers. All summer, 6 in.

Gentian • Gentiana

Bottle Gentian. Gentiana andrewsi. Bushy, leafy plants with clusters of pointed, dark blue buds which never open. Very odd and handsome. Half shade, moisture. 12 to 18 in. $30 \mathrm{cts}$. each, $\$ 3$ for $12, \$ 20$ per 100 .

Goutweed • Ægopodium

SILVER-EDGED. Agopodium podograria (variegata). A quick-growing mat of pretty, silvery edged leaves. For borders and rockeries. Sun, 6 to 8 in.

Gypsophila • Gypsophila

Creeping. Grpsopbila repens. Dense, carpet-like plant, spangled with tiny white or pinkish flowers. Sun or half shade. June, July. 6 in.

\section{Heuchera • Heuchera}

Coral Bells. Heuchera sanguinea. Rosette of strong, dark leaves with red and pink bells on slender stems. Very lovely. Dry, half shade. 18 in. 30 cts. each, $\$ 3$ for $12, \$ 20$ per 100 .

Pink Bells. $H$. brizoides. Similar in habit, with red stems and pale pink flowers. Dry, half shade. 18 in. 30 cts. each, $\$ 3$ for $12, \$ 20$ per 100 .

\section{Larkspur · Delphinium}

SLENDER. Delphinium grandiflorum chinense. Feathery foliage and intense blue flowers in loose sprays. Sun. June-August. 12 to 18 in.

SLENDER, WhITE. D. grandiflorum chinense (album). The same, with pure white flowers. Both are excellent for the rockery if plants of their stature a re needed.

All plants on this page. except where noted, are 25 cts. each. $\$ 2.50$ for $12, \$ 18$ per 100 . Six of one kind sold at the 12 rate; 50 of one kind at the 100 rate. 
Loosestrife - Lysimachia

Moneywort. Lysimacbia nummularia. Creeper, with long sprays of round leaves and brilliant yellow flowers. Excellent ground-cover. Sun or half shade. June-August. 2 to 4 in.

\section{Lychnis - Lychnis}

German Catchfly. Lycbnis viscatia (splendens). Heads of small, double red and pink flowers. Sun. May, June. 20 to 28 in. 30 cts. each, $\$ 3$ for 12 , $\$ 20$ per 100 .

HAAGE's. L. baageana. Low, sticky plants, crowned with blazing scarlet flowers of great beauty. Sun. June-August. $1 \mathrm{ft}$. 30c. each, $\$ 3$ for $12, \$ 20$ per 100 .

\section{Orchid · Cypripedium}

Moccasin Flower. Cypripedium acaule. Two leaves flat on the ground and one or more soft rose-pink, slipper-shaped flowers. Dry, sour soil, in shade. April, May. 6 to 12 in. 30 c. each, $\$ 3$ for 12.

Showy Lady's Stipper. C. spectabile. Vigorous plants with large, pink and white flowers of the utmost beauty. Moist shade, swamp if possible, sour soil. 1 to $2 \mathrm{ft}$. $40 \mathrm{cts}$. each, $\$ 4$ for 12 .

Yellow LAdY's Slipper. C. pubescens. Broad leaves on erect stem, with waxy, yellow and brown flowers of similar shape. Moist shade. ApriI, May. $1 \mathrm{ft}$. $30 \mathrm{cts}$. each, $\$ 3$ for 12 .

\section{Pachysandra • Pachysandra}

JAPANESE Spurge. Pacbysandra termina is. A leafy, low plant, bright green aII year, especially useful in shady places and for carpeting the ground under trees. Dry shade. 6 to 12 in.

\section{Phlox • Phlox}

Amana. Pblox amona. Slender stems and clusters of purple-pink flowers over a long season. Sun, dry soil. June, July. 6 to 8 in.

White Phlox. P. divaricata (alba). A white form of the common Wild Blue Phlox. Very delicate and lovely.

Wild Blue Phlox. P. divaricata. Very lovely, lavender-blue flowers in huge clusters. Plants very slender. Shade or half shade; some moisture April, May. 6 to 12 in.

Moss Pink. P. subulata. Creeping, mossy plant covered in spring with a multitude of brilliant flowers. Useful rock plants, forming broad mats of green and great sweeps of early spring color. They are evergreen and attractive when out of flower. Full sun. April, May, 3 to 6 in. Obtainable in the following varieties.

Alba. Pure white.

Lilacina. Light lavender-bue.

Rosea. Bright pink.

Stellariana. Clear light blue.

\section{Pinks • Dianthus}

Everblooming Pink. Diantbus plumarius (semperflorens). A form of the Grass Pink which blooms on and off all season. Sun. 8 to 12 in.

Grass Pink. D. plumarius. The sweet old Garden Pink with tufts of gray foliage and fragrant, fringed flowers of pink and white. Sun. May, June. 8 to 12 in.

MAIDEN Pink. D. deltoides. Low, sod-like plants, covered with tiny rose-red, fringed Pinks in June and July. Superb rock plant and also very useful for edging. Sun. 2 to 6 in.

All plants on this page, except where noted, are $25 \mathrm{cts}$. each, $\$ 2.50$ for $12, \$ 18$ per 100 . Six of one kind sold at the 12 rate; 50 of one kind at the 100 rate.

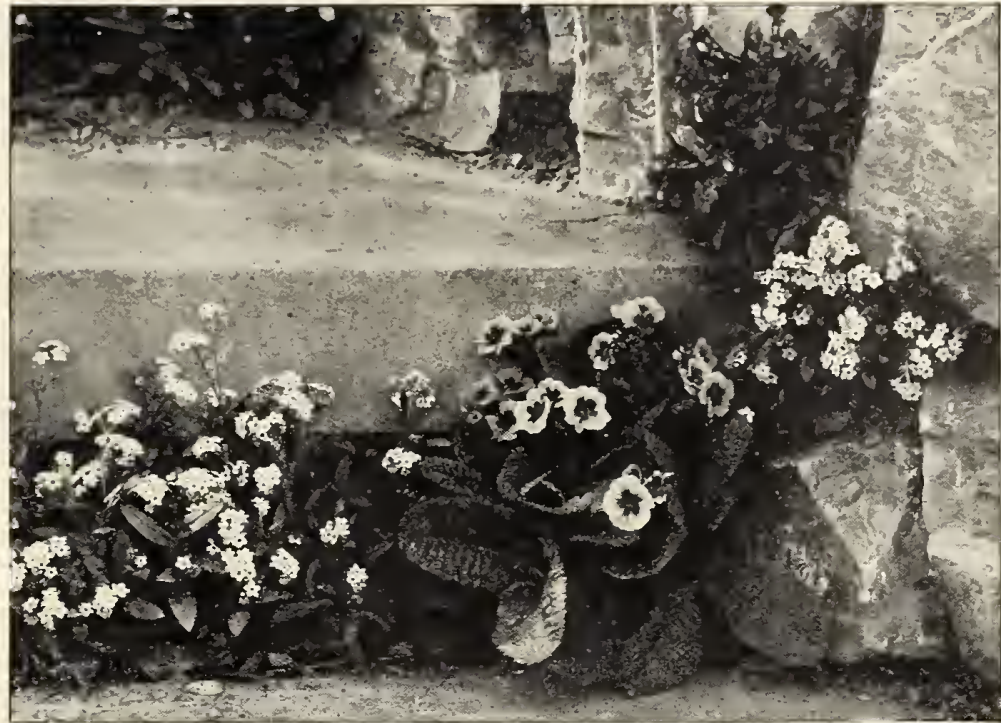

Forget-me-nots and a Polyantbus set in the crevices of a wall and at the base of a stone step

garden than by studying the common plants assiduously to learn where best they grow, and to discover their adaptability to places and conditions for which they are not usually recommended. It is surprising what beautiful results may follow.

AII the plants listed in the adjacent columns are perennials of the type best adapted to rockwork, but do not demand it. They are equally suitable for edging borders of other plants in the conventional garden or for tucking into little nooks and corners

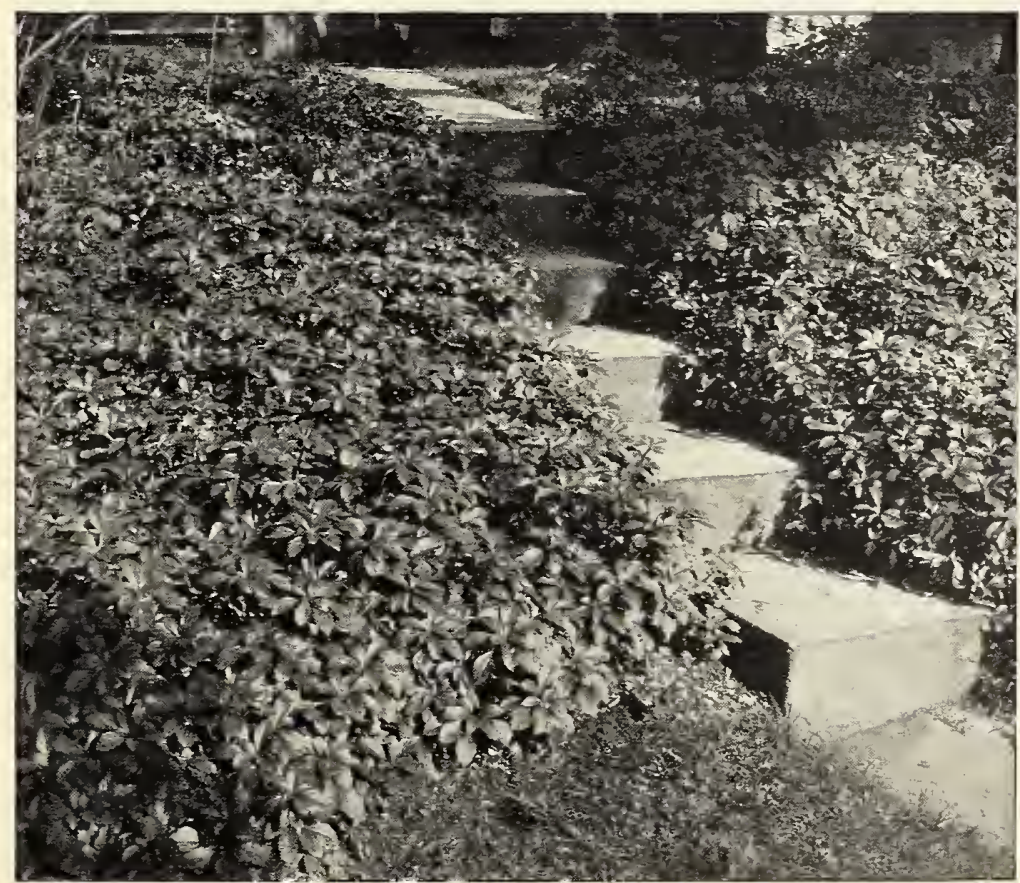

Pacbysandra used on a sbady bank makes an agreeable ground cover at all seasons of the year 


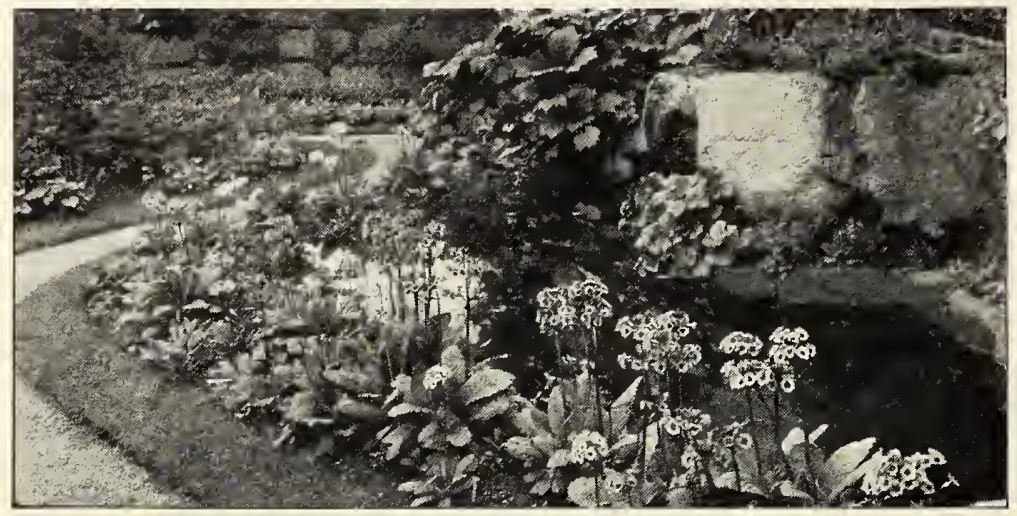

Japanese Primroses set at the water's edge. They will thrive just as well in moist soil anywbere, preferably in partial shade

where they will be welcome. The Pinks are good flowers in the ordinary borders and the Maiden Pink is one of the most useful edging plants. The same is true of Rock Cress, Moss Pink (Pblox subulata), the Veronicas, Plumbago, Thyme, and several others.

The Polyanthuses and Primroses are useful for the same purposes if they are given plenty of water and a little shade, and one frequently encounters splendid edgings of the English Daisies.

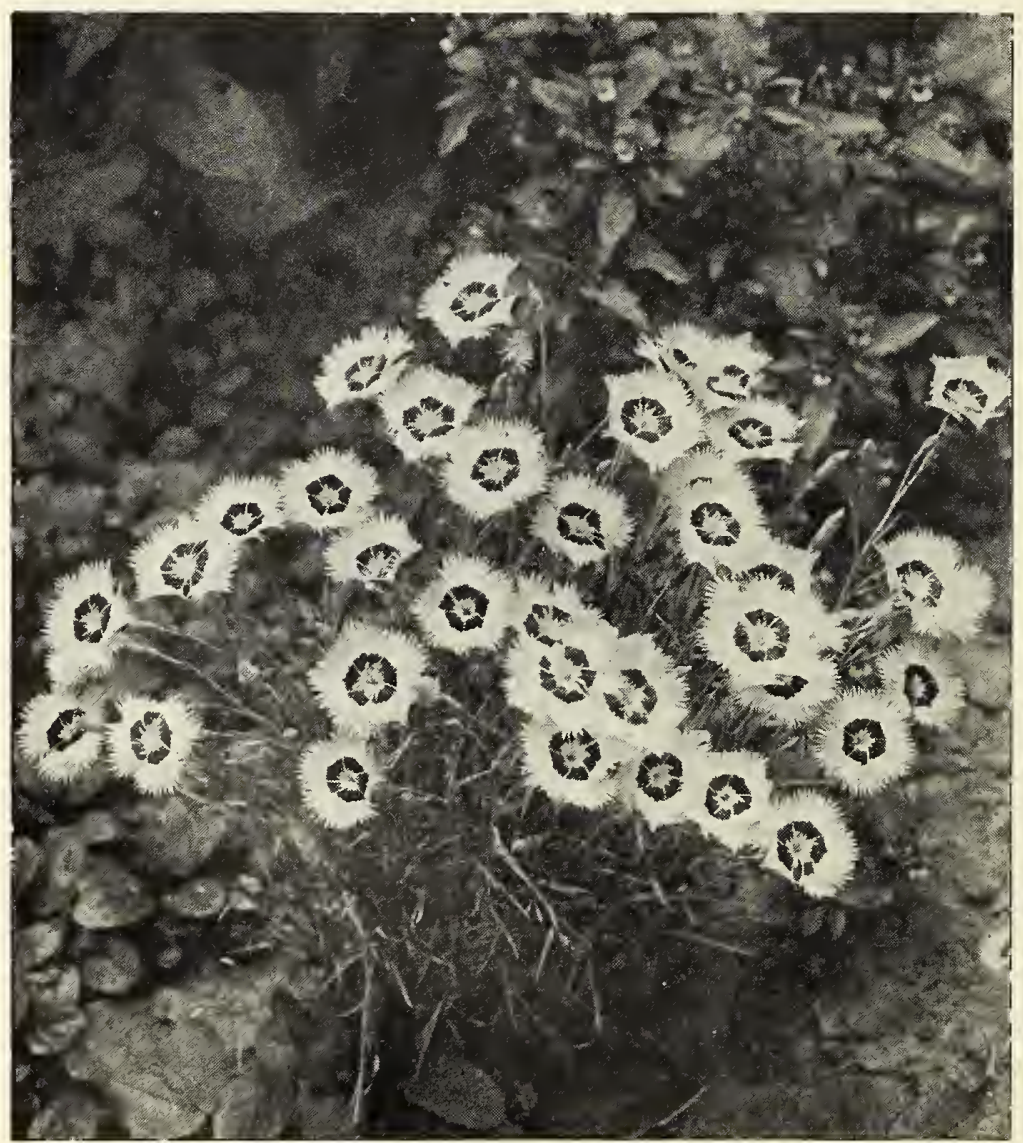

The Grass Pink, covered witb its baloed flowers is an ideal rock garden plant

\section{Platycodon - Platycodon}

DWARF Balloon Flower. Platycodon grandiflorum (mariesi). Erect, wiry stems with large, dark blue flowers. Showy rock plant. Sun. June, July. $1 \mathrm{ft}$.

\section{Plumbago - Ceratostigma}

LARPENT's (Blue Leadwort). Ceratostigma plumbaginoides. Beautiful, leafy, wiry plants covered with steel-blue flowers. Very showy and attractive. Sun. August-October. 6 to 12 in. $30 \mathrm{cts}$. each, $\$ 3$ for $12, \$ 20$ per 100 .

\section{Polemonium - Polemonium}

Greek Valerian. Polemonium reptans. Slender, very graceful plant, with drooping clusters of bell-like flowers. Half-shade, moisture, $1 \mathrm{ft}$. 30 cts. each, $\$ 3$ for $12, \$ 20$ per 100 .

JACOB's LAdDER. $P$. cæruleum. Arching, Iadderlike leaves, with clusters of very showy, bright blue, bell-like flowers. Moist shade. AprilJune. 1 to $2 \mathrm{ft}$.

Richardson's. P. bumile. Sturdy, bushy plants crowned with bright blue flowers in great abundance. Excellent foliage all season. Sun, or half shade. June, July. 12 to 18 in.

Polyanthus - Primula

LARGe-FLowered White. Primula polyantbus. Rosettes of beautiful leaves surmounted by clustered flowers of various white and tinted shades. Very fine.

LARGE-FLowered Hybrids. $P$. polyantbus. AIl shades of pink, rose, yellow, crimson, cream, and white. Very lovely.

\section{Primrose • Primula}

JAPANese. Primula japonica. Bushy little plants with erect stems, bearing circles of rosy purple flowers of great beauty. Moist, half shade. June. 10 in. 30 cts. each, $\$ 3$ for $12, \$ 20$ per 100 .

Kashmir. $P$. denticulata (casbmeriana). Clusters of broad leaves surmounted by strong stems bearing heads of large, dark purple flowers with yellow centers. Very handsome. Semi-shade. March, April. 6 to 18 in. 30 cts. each, $\$ 3$ for $12, \$ 20$ per 100.

\section{Rock Cress - Arabis}

Alpine. Arabis alpina. Trailing plant with gray foliage smothered in clusters of white flowers in early spring. Splendid rock and edging plant. Excellent on walls. Full sun. April, May. 6 to 12 in.

Alpine, Double. A. alpina. The same, but the flowers are double and the heads denser. $40 \mathrm{cts}$. each, $\$ 4$ for $12, \$ 30$ per 100 .

Sage - Salvia

Round Top. Salvia globosa. A biennial with very large, flat leaves in a silvery rosette the first year; second season, blooms on stalks 3 feet high, curved to form a sphere. Sun. June, July.

Silvery SAge. S. argentea. A biennial with very attractive, broad, woolly, silvery leaves and showy pinkish white flowers. Sun, dry soil. June. 2 to $4 \mathrm{ft}$. when in flower.

Sandwort - Arenaria

Mountain Sandwort. Arenaria montana. Low, dense, matted leaves, and large, glistening white flowers. Sun. April, May. 3 to 6 in. 30 cts. each, $\$ 3$ for $12, \$ 20$ per 100 .

All plants on this page, except where noted, are 25 cts. each. $\$ 2.50$ for $12, \$ 18$ per 100 . Six of one kind sold at the 12 rate, 50 of one kind at the 100 rate. 


\section{PLANTS FOR ROCK GARDENS}

\section{Saxifrage • Saxifraga}

Heart-leaved. Saxifraga cordifolia. Bright pinl clusters of flowers very early in spring, followed by broad, shining, dark green leaves. Sun or semi-shade, moisture. March, April. 1 to $2 \mathrm{ft}$. 30 cts. each, $\$ 3$ for 12 , \$20 per 100 .

Leichtlin's. S. lingulata. A similar form with dark pink flowers and crimson leaves. Halı shade, moisture. April, May. 12 to 18 in. $30 \mathrm{cts}$. each, $\$ 3$ for $12, \$ 20$ per 100 .

\section{Sea Lavender • Limonium}

Broad-leaved Statice. Limonium latifolium Open clusters of chaffy, lavender-blue flowers which may be dried. Sun; deep, moist soil. August. 15 in.

\section{Silene · Silene}

Alpine Catchfly. Silene alpestris. Compact leaves with large white flowers in clusters. Dry, half shade. May, June. 3 to 6 in. 30 cts. each, $\$ 3$ for 12 , $\$ 20$ per 100 .

Autumn Catchfly. S. scbafta. A similar plant with purplish pink flowers. Dry, half-shade. August, September. 4 to 6 in.

Soapwort - Saponaria

SOAPWORT. Saponaria ocymoides. Densely matted plants studded with rosy pink flowers. Sun, indifferent soil. May, June. 8 to 12 in.

\section{Stachys - Stachys}

Woolly Betony. Stacbys lanata. Woolly, silvery plants of great ornamental value. Flowers small, purple. Sun. June, July. 12 to 18 in.

\section{Stonecrop - Sedum}

One of the most useful tribes of rock plants, with many very attractive members. All of them enjoy dry soil and sunny locations, but they are very adaptable to almost any situation.

Golden Moss. Sedum acre. Creeping, moss-like plant, covered with bright yellow flowers. July. 2 to 3 in.

Jenny's. $S$. reflexum. Diffuse creeper with orangeyellow flowers. July. 2 to 3 in.

RunNing. S. stoloniferum. Low cre eper, with pink flowers. June, July. 6 in.

Showy Sedum. S. spectabile. Erect, tufted plant with thick, broad leaves and showy heads of dull rose-pink flowers. September, October. 12 to 18 in.

Siebold's. S. sieboldi. Beautiful gray-green foliage. Flowers pink. August, September. 9 in.

White. S. album. Similar to the Golden Moss but has white flowers. July. 2 to 3 in.

\section{Teucrium - Teucrium}

Germander. Teucrium cbamædrys. A halfshrubby, half-evergreen plant with white, rose, and purple flowers. Sun. July, August. 1 to $2 \mathrm{ft}$. 35 cts. each, $\$ 3.50$ for 12 , $\$ 25$ per 100 .

\section{Thrift - Statice}

FAlse Thrift. Statice pseudoarmeria. Grassy tufts of foliage, with heads of pink flowers on slender stems. Sun. July. 8 to $12 \mathrm{in.}$

Peachblow. S. armeria (splendens). Similar tufts of evergreen foliage and heads of vivid pink flowers. July, August. 9 to 12 in. 30 cts. each, $\$ 3$ for $12, \$ 20$ per 100 .

All plants on this page, except where noted, are $25 \mathrm{cts}$. each, $\$ 2.50$ for $12, \$ 18$ per 100 . Six of one kind sold at the 12 rate, 50 of one kind at the 100 rate.

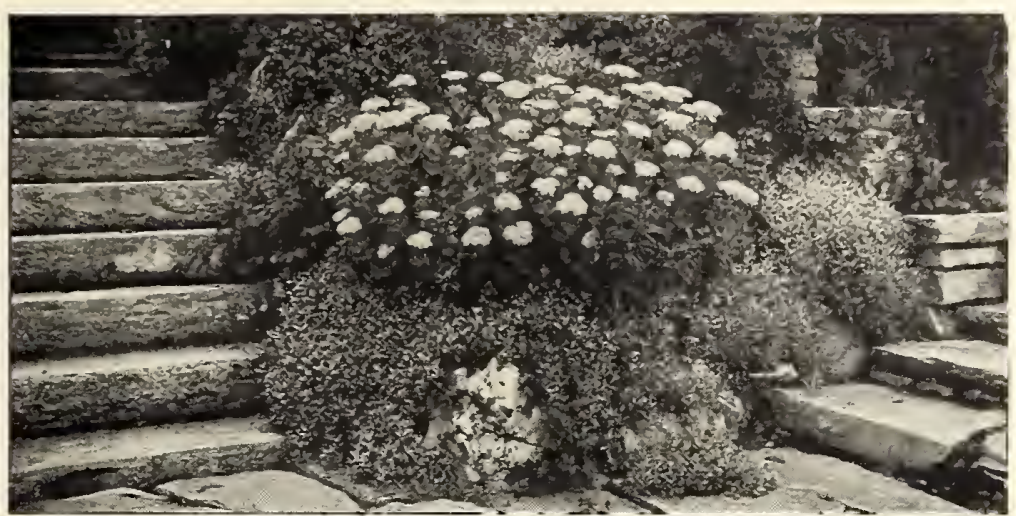

The Sbouy Sedum makes a fine bold mass of soft rose-color in late summer

Besides the rock plants mentioned here, there are many dwarf shrubs which are indispensable in a rockery of any dimensions. The Garland Flower (Daphne) is a splendid rock plant; certain Junipers, the Mugho Pine, several Azaleas, the Leucothoë, Gold Flower, and other less vigorous shrubs are all useful in building up the background or in establishing height at places where it is needed.

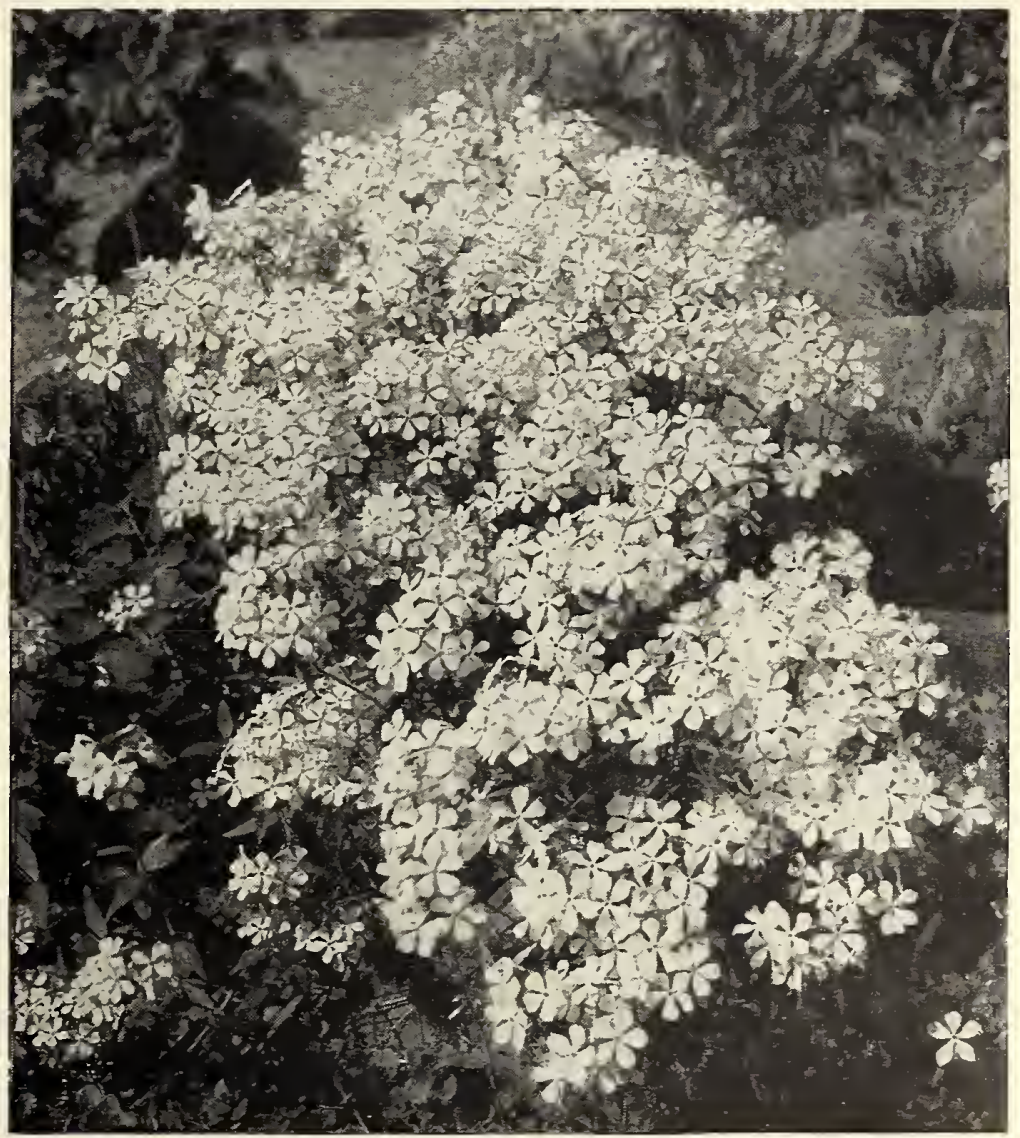

Wild Blue Pblox is one of our loveliest native plants and is just as good in the rockery as in the woods 


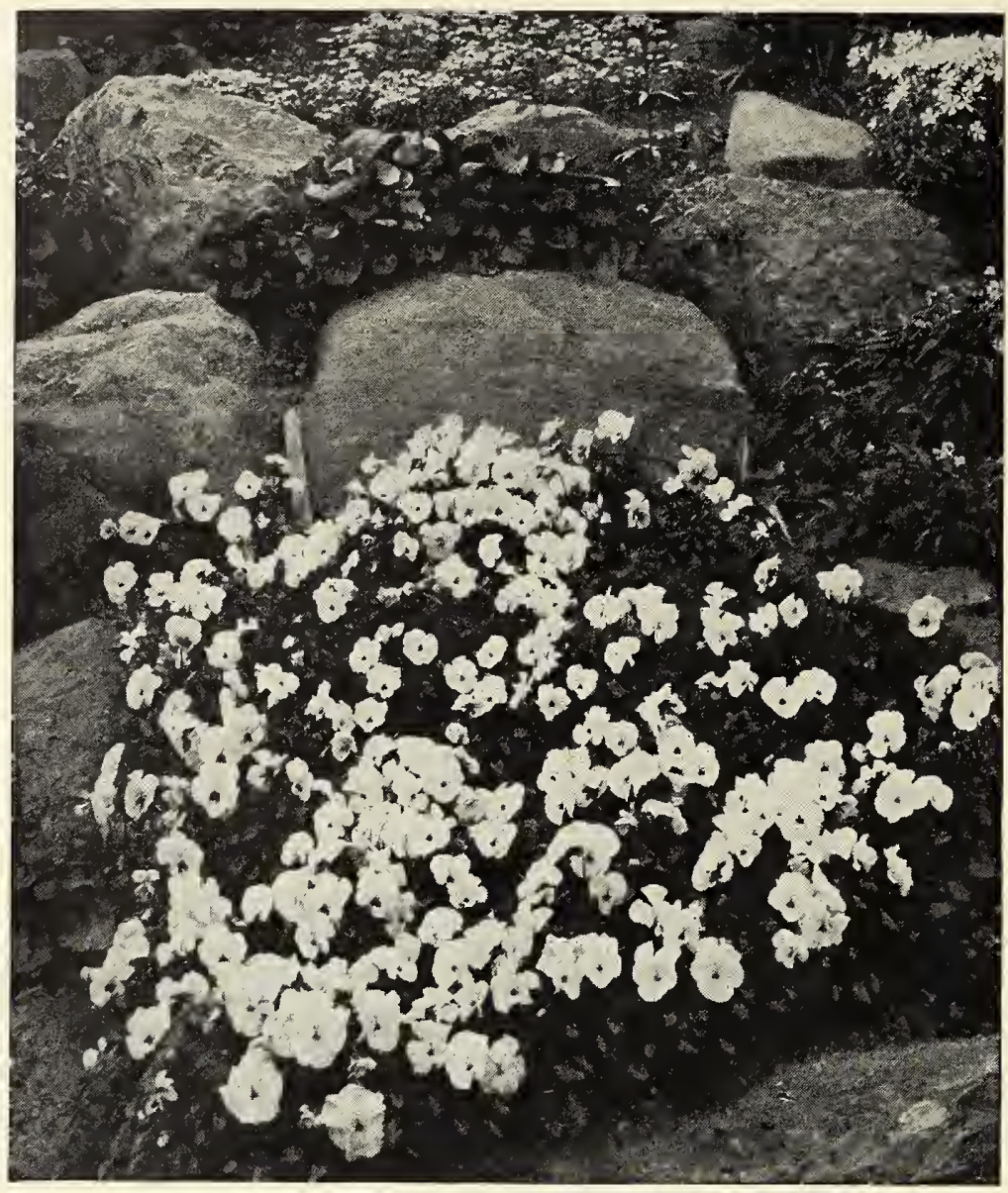

White Violas keep up all summer bloom among the cool stones
Thyme - Thymus

Woolly. Tbymus serpyllum (lanuginosus). Flat, creeping, fragrant specres for planting in crevices. Flowers small and insignificant. Foliage very lovely. Sun. 1 in. 30 cts each, $\$ 3$ for $12, \$ 20$ per 100.

Tunica - Tunica

Tunic Flower. Tunica saxifraga. Grassy tufts covered with a misty spray of tiny pinkish flowers. Sun. July-September. 6 to 8 in.

Veronica - Veronica

Creeping Speedwell. Veronica repens. Dense, carpeting plant with low, erect sprays of pinkish blue flowers. Sun or half-shade. Prefers moisture. June, July. 2 to 4 in.

Rock Speedweli V.teucrium rupestris. Prostrate, matted trailer of great beauty, a mass of Iittle bright blue spires in June. Sun, 2 to 5 in.

Viola - Viola

HoRned Violets (Tufted Pansies). Viola cornuta. Plants of the pansy type, but more compact and hardier. Flowers shaped like violets, but Iarger, and have wider range of color. Moisture, halfshade. All season. We offer following varieties.

Mauve QueEn. Flowers reddish violet.

Papilio. Bright violet-blue, with darker eye. One of the most continuous flowering. Very attractive.

Purple Queen Purplísh violet.

Whire. Large, pure white, with yellow eye.

Wallflower - Cheiranthus

Siberian. Cheirantbus allioni. Extremely showy plants with large heads of burning yellow-orange flowers. Sun. April-June. 6 to $12 \mathrm{in}$.

Otber Rock Plonts moy be found in the Decorotive Sbrub Section. See Gorlond Flower, Azoleo, Leucotboe, Juniper, Yew, Gold Flower, etc.

All plants on this page, except where noted, are $25 \mathrm{cts}$. each, $\$ 2,50$ for $12 . \$ 18$ per 100 Six of one kind sold at the 12 rate; 50 of one kind at the 100 rate.

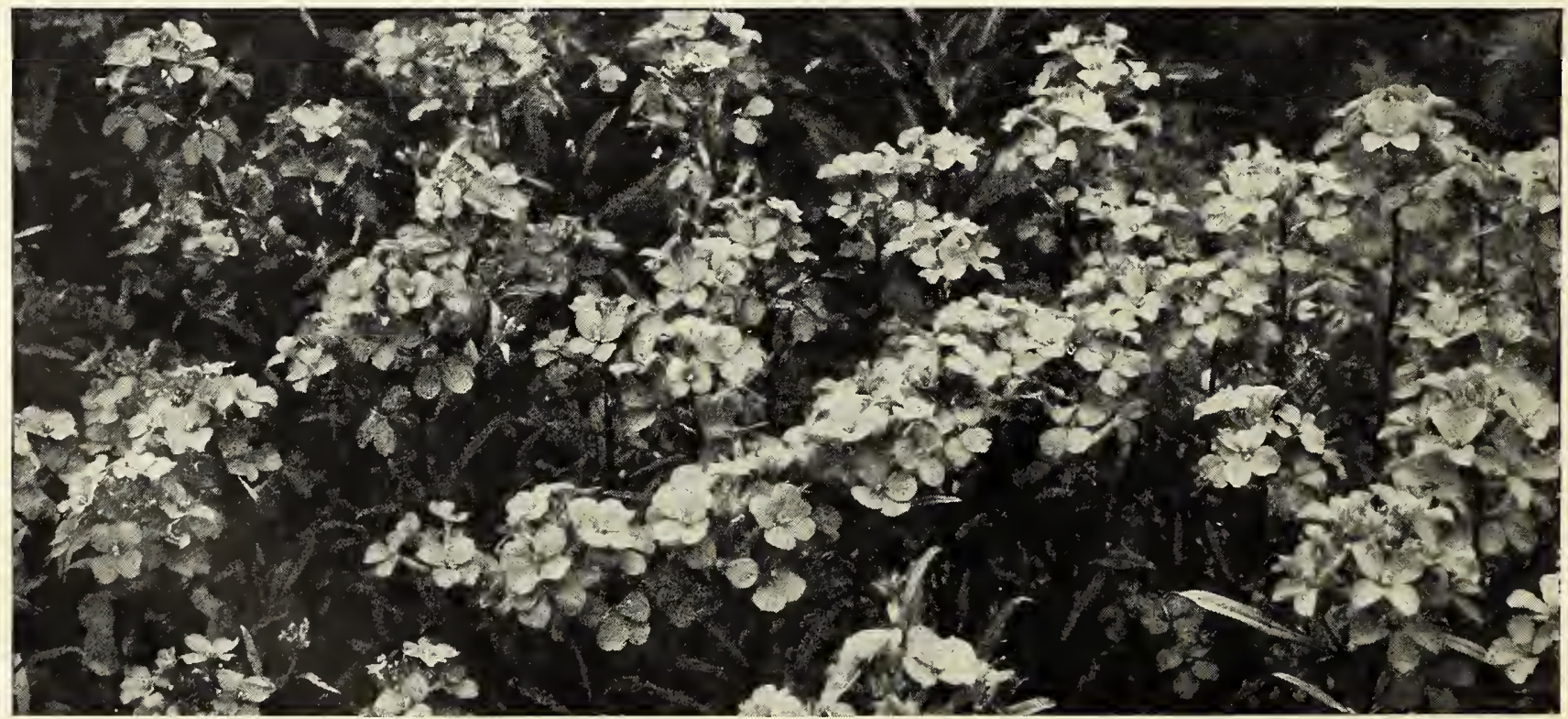

The Siberian Wallflower is a blaze of burnt orange in spring and continues until midsummer 


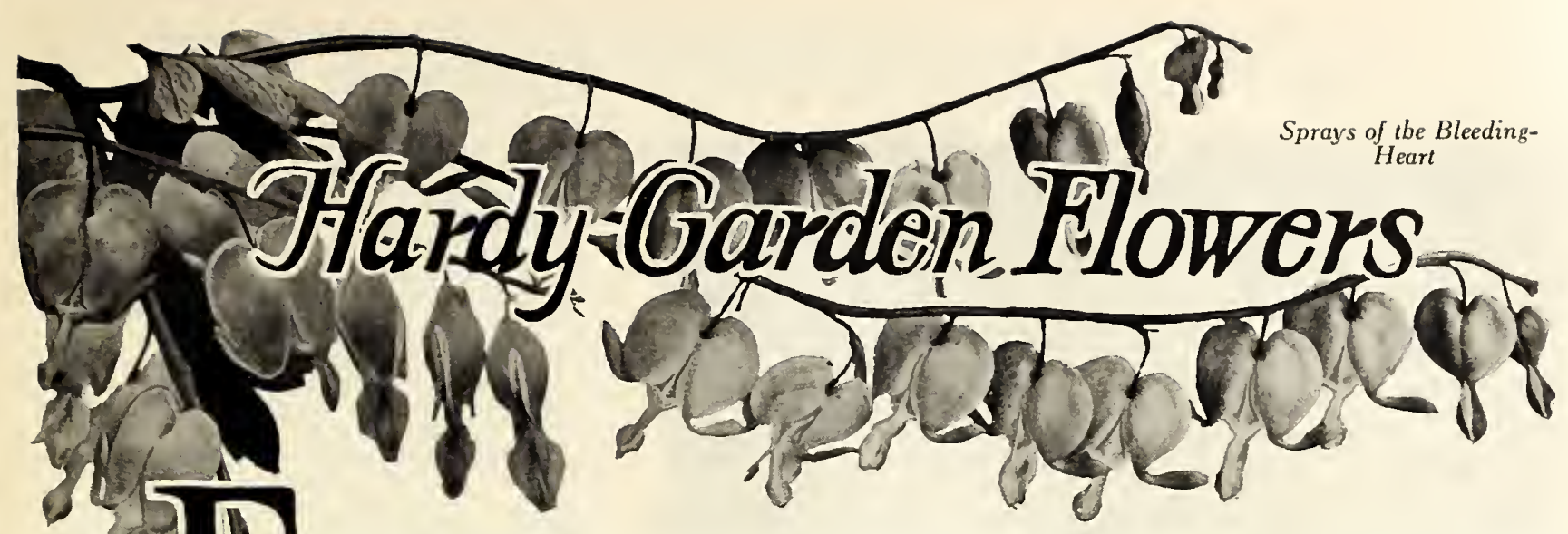

AMOUS gardens have been devoted to one kind of flower. There are great rose-gardens, iris-gardens, peony-gardens, rock-gardens, and, in extreme instances, gladiolus-gardens and dahlia-gardens, all of which have special value for collectors and specialists, but are less satisfying to most of us. Variety is the spice of gardening as it is of life, and any garden wholly devoted to one flower is a little empty from the beginning, and soon becomes tiresome.

Nevertheless, a garden should specialize in something. No gardener has the time, the patience, and the skill to grow all things with equal success.

Perennials mentioned in tbe text and many otber beautiful species are offered in tbis column. For otbers not listed bere, consult tbe Index.

\section{Achillea • Achillea}

Cerise Queen. Acbillea millefolium. Flat clusters of deep cerise-pink flowers, excellent for cutting. July. 18 in.

Pink Yarrow. A. millefolium (roseum). A pretty, light pink form of the common freld Milfoil or Yarrow. July. 18 in.

The Pearl. A. ptarmica. Wiry plants topped with clusters of pure white flowers. Excellent for cutting and for filling in spaces between other plants. June-September. 18 in.

\section{Aconite - Aconitum}

MoNKSHOOD. Aconitum napellus. Slender, but rigidly erect plants, with dense spikes of curiously hooded, dark blue flowers. Likes shade. July, August. 3 to $4 \mathrm{ft}$. $40 \mathrm{cts}$. each, $\$ 4$ for 12 .

Fischer's. A. fiscberi. Similar plants, a little taller, flowers lighter blue. One of the best autumn-blooming perennials. Likes half shade. September, October. 4 to $5 \mathrm{ft}$. $40 \mathrm{cts}$. each, $\$ 4$ for 12 .

\section{Anchusa - Anchusa}

Dropmore. Ancbusa italica. Bold, coarse-leaved plants sending up strong stems, much branched, bearing innumerable vivid blue flowers. June, July. 3 to $4 \mathrm{ft}$.

Forget-me-not Anchusa. A. myasotidiflota. See Rock Garden Section, page 43.

\section{Anemone - Anemone}

JAPANESE. Anemone japonica (alba). Exquisitely lovely white flowers in great clouds at the top of lofty, wiry stems. Especially fine against a background of evergreens and particularly valuable for its late season of bloom. September, October. 3 to $5 \mathrm{ft}$.

All plants on this page, except where noted, are $25 \mathrm{cts}$. each, $\$ 2.50$ for 12 , $\$ 18$ per 100 . Six of one kind sold at the 12 rate; 50 of one kind at the 100 rate.
One of the first requisites for a successful garden, we think, is to choose one flower which you like supremely well and concentrate your gardening energies upon it, but not to the utter exclusion of other things.

Such other things comprise the Hardy Garden Flowers, commonly called Hardy Perennials, none of which is important enough to be allowed exclusive domain. A garden of Phloxes, even if it were extended to include all types and species of that most useful and varied genus, would be a great bore as the season advanced and nothing happened except a continuous explosion of one kind of Phlox after another. A garden wholly of Delphiniums would probably wear you out trying to live in the continual ecstasy demanded by their presence. A garden of Irises is a great joy until July, but after that you simply must grow something else or be without a garden. The same is true of Peonies. Roses may be had aII season but it is difficult to live up to Roses all the year round. The demands of royalty are too great; we weary of queens in time and should like a little daIliance with the handmaidens.

Now the handmaidens are many and attractive. Volumes have been written about them and how to use them in the garden. The chief thing is to secure succession of bloom, variety in habit of plants and shape of flowers, and to create pleasing harmonies in color and mass. This takes study.

\section{Flowers All Season}

It is impossible to have a continual blaze of color all summer long in identical spots, unless you have the means to throw away plants which have finished blooming and replace them with others which have been grown in pots or in some fashion which permits transplanting at that time. But you can have a succession of bloom in different parts of the garden-a sort of shifting of interest from spot to spot-so that the attention is focused upon one 


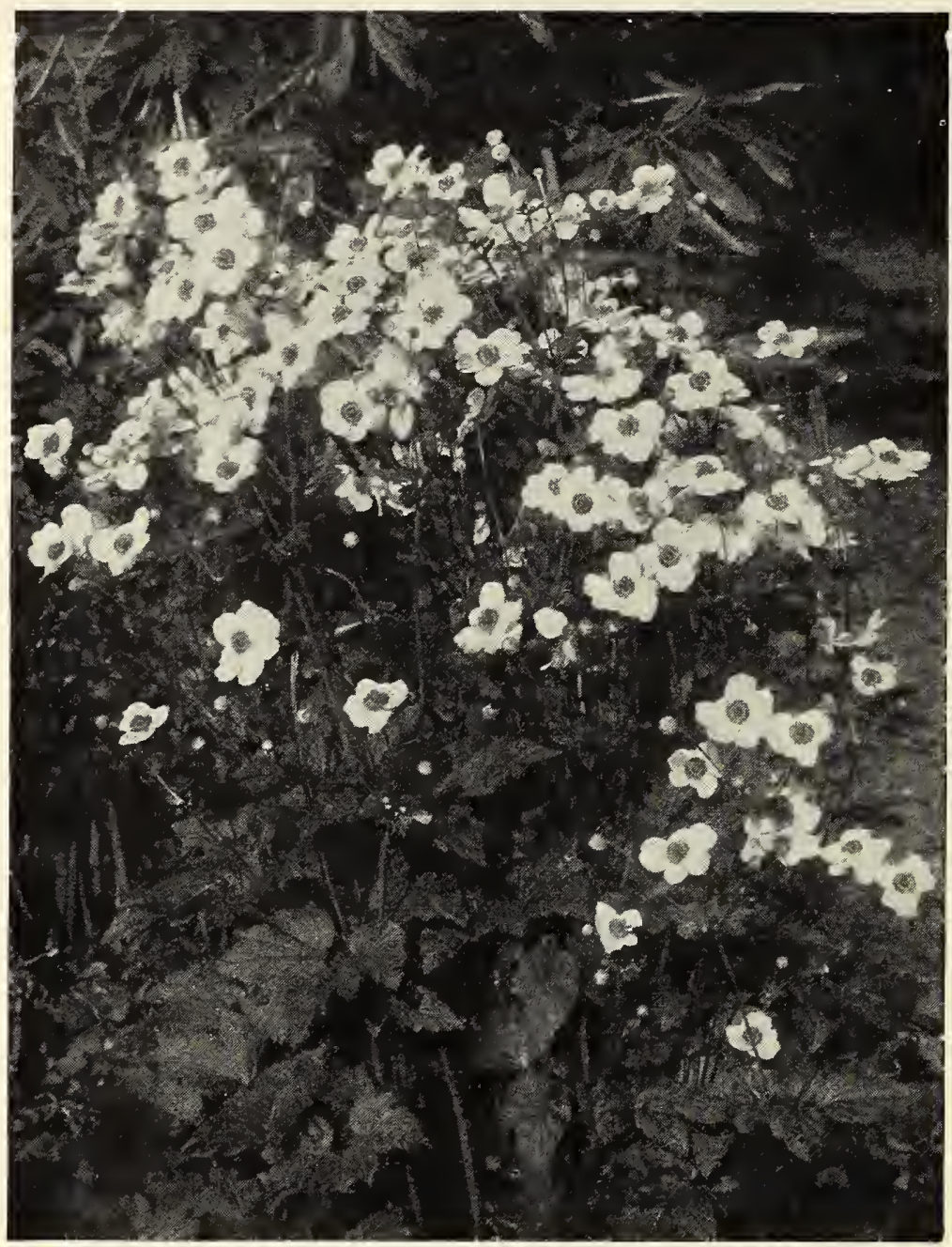

The Japanese Anemone is one of the most graceful of late summer flowers. It is easy to grow, and permanent

feature of the place at a time. Skillful planning will even enable you to use the same ground several times, so that the ground which was occupied by Tulips in the early spring may be a blaze of annuals in August, and a mound of Chrysanthemums in late autumn. Narcissus may be followed by Irises, which, in turn, give way to the August Lilies, and they may be followed by Hardy Asters, and so on. In the descriptive columns of this book, we have entered the height and blooming season of each plant which will assist in assembling them for succession of bloom.

There are hundreds of early and late-spring-blooming perennials, a good many of which will be found described in the section devoted to rock plants, but the perennial season can hardly be said to open officially until the Irises and Peonies arrive. Before that time we rely upon Tulips and the host of their bulbous allies for brightness near the ground, and upon the shrubs for taller beauties. A few perennials are outstanding at that season: the Columbine, far too much neglected in many gardens; the gorgeous Oriental Poppies; and an army of little flowers. At the close of
ANEMONE, continued

Prince Henry. A. japonica. Dark, rose-red flowers of great beauty. The plant is dwarf and very profuse-flowering. September, October. 2 to $3 \mathrm{ft}$.

Queen Charlotte. A. japonica. A charming variety of the Japanese Anemone, with silvery pink flowers of great value for cutting. 30 cts. each, $\$ 3$ for $12, \$ 20$ per 100 .

Wharlwind. A. japonica. A semi-double, frilled Japanese Anemone, generally considered the handsomest of the white-flowering varieties. September, October. 3 to $5 \mathrm{ft}$.

Otber Anemones will be found in tbe Rock Garden Section, Aster • Aster

The Asters are sometimes called "Michaelmas Daisies," and are one of the glories of autumn. All the named varieties described are descended from various American wild species, chiefly the New York Aster, A. novi-belgi and the New England Aster, $A$. novæ-anglix; their true origin is very difficult to trace. Certain dwarf Asters are described in the Rock Garden Section, page 43.

Climax. One of the finest blue varieties. Large flowers in great profusion. August, September. 3 to $4 \mathrm{ft}$.

Feltham Blue. Much darker blue than Climaxa very rich color. September, October. 3 to $4 \mathrm{ft}$.

Harvardi. Very attractive light lavender-blue. September. 4 to $5 \mathrm{ft}$.

Mrs. F. W. Raynor. Large, dark rosy crimson flowers. September, October. 4 to $5 \mathrm{ft}$.

Ruber. An excellent dark crimson-pink variety. September. 3 to $4 \mathrm{ft}$.

William Bowman. A very showy, bright redpurple variety with bronze centers. AugustOctober. 4 to $5 \mathrm{ft}$.

\section{Astilbe - Astilbe}

Very handsome border plants, with excellent foliage which is attractive all season. In June and July they throw up tall stems bearing feathery masses of exquisite little flowers. They like moist, rich soil and partial shade but will endure some dryness and full sunlight. The varieties we offer are those new hybrid forms of Astilbe davidi, known commercially as $A$. arendsi.

Ceres. Graceful panicles of light rose-pink flowers with a silvery sheen. June, July. 2 to $4 \mathrm{ft}$. $50 \mathrm{cts}$. each, $\$ 5$ for 12 .

Moerheim. Extremely large flower-clusters of rich, creamy"white. June, July. 5 to $6 \mathrm{ft}$. $50 \mathrm{cts}$. each, $\$ 5$ for 12 .

Pink Pearl. Smaller panicles but many of them; clear, deep, rose-pink. June, July. $3 \mathrm{ft}$. $50 \mathrm{cts}$. each, $\$ 5$ for 12 .

Pyramidalis. Large, pyramidal clusters of pure, snow-white. June, July. 2 to $4 \mathrm{ft}$. 50 cts. each, $\$ 5$ for 12 .

\section{Bamboo • Arundinaria}

Arrow Bamboo. Arundinaria japonica. A tall Reed with broad leaves, producing a handsome, tropical effect. Flowers unimportant. 5 to $10 \mathrm{ft}$. $\$ 1.50$ each, $\$ 15$ for 12 .

\section{Baptisia - Baptisia}

FAlSE Indigo. Baptisia australis. Bushy plant with attractive foliage all season. Flowers dark blue, in small, lupine-like clusters, followed by conspicuous, twisted pods. June. 2 to $4 \mathrm{ft}$.

All plants on this page, except where noted, are 25 cts. each, $\$ 2.50$ for $12, \$ 18$ per 100 . Six of one kind sold at the 12 rate; 50 of one kind at the 100 rate. 


\section{Belamcanda - Belamcanda}

BlackBerry Lily. Belamcanda cbinensis. Irislike foliage with tall, branched stems bearing numerous, small, lily-like flowers of red and orange, followed by clusters of black seeds which look like large blackberries. Excellent for dry borders, in sun. 2 to $3 \mathrm{ft}$.

\section{Bellflower - Campanula}

Canterbury Bells. Campanula medium. One of the handsomest of garden flowers, making pyramidal plants covered with erect, bell-like flowers of great beauty. June, July. 2 to $3 \mathrm{ft}$. May be had in separate colors: Pink, Blue, and White.

Peach Bells. C. persicifolia. More persistent than the Canterbury Bells. The stalks are spirelike, the bells are smaller, and drooping. Two varieties: Blue and White. July. $3 \mathrm{ft}$.

Chiment Bellflower. C. pyramidalis. Noble, erect plants, covered with innumerable, rather small, bell-shaped flowers. Not as easy to have as the others but the finest. August, September. 5 to $7 \mathrm{ft}$. Two varieties: Blue and White.

Diamond Bellflower. C. rbomboidalis. Slender, wiry plant with clusters of drooping, double blue flowers. July, August. 1 to $2 \mathrm{ft}$. $\$ 3$ for $12, \$ 20$ per 100.

\section{Bleeding-Heart • Dicentra}

BleEding-Heart. Dicentra spectabilis. An old, well-loved garden plant with ferny foliage, and long, drooping sprays of large, heart-shaped, rosepink flowers. May. 2 to $3 \mathrm{ft}$. $60 \mathrm{cts}$. each, \$6 for 12 .

Fringed Bleeding-Heart. D. eximia. A lower plant, with finer leaves and smaller flowers, but in bloom all season. Fine in shade, and an excellent rock-garden subject. All summer. 8 to 12 in. 30 cts. each, $\$ 3$ for $12, \$ 20$ per 100 .

\section{Bocconia • Bocconia}

Plume Poppy. Bocconia cordata. Beautiful, curled foliage and tall stems bearing dense heads of inconspicuous flowers, followed by attractive flat seed-pods of great decorative value. Excellent in dry, sterile places, for a screen or accent point. July. 6 to $8 \mathrm{ft}$.

Plume Poppy, Bronze. B. microcarpa. Similar, but taller and the flowers are bronzy yellowbrown. July. 7 to $9 \mathrm{ft}$.

Boltonia - Boltonia

False Camomize. Boltonia asteroides. Erect plants with pinkish flowers very much like hardy asters. August, September. $41 / 2$ to $5 \mathrm{ft}$.

Violet Boltonia. B. latisquama. Much the same except that the flowers are a trifle larger, and violet-blue. August, September. $41 / 2$ to $5 \mathrm{ft}$.

\section{Bugbane - Cimicifuga}

Bugbane. Cimicifuga racemosa. Tall stems with branching spikes of tiny starry flowers, faintly fragrant. An extremely picturesque and effective plant of great beauty. Half-shade, leaf-mold, and moisture. June, July. 5 to $8 \mathrm{ft}$. $30 \mathrm{cts}$. each, $\$ 3$ for $12, \$ 20$ per 100 .

\section{Buttercup - Ranunculus}

Double Buttercup. Ranunculus actis. A doubleflowering form of the common, native Buttercup, with very handsome, rich, glossy, yellow flowers. May, June. 2 to $3 \mathrm{ft}$.

All plants on this page, except where noted, are 25 cts. each, $\$ 2.50$ for $12, \$ 18$ per 100 . Six of one kind sold at the 12 rate; 50 of one kind at the 100 rate.

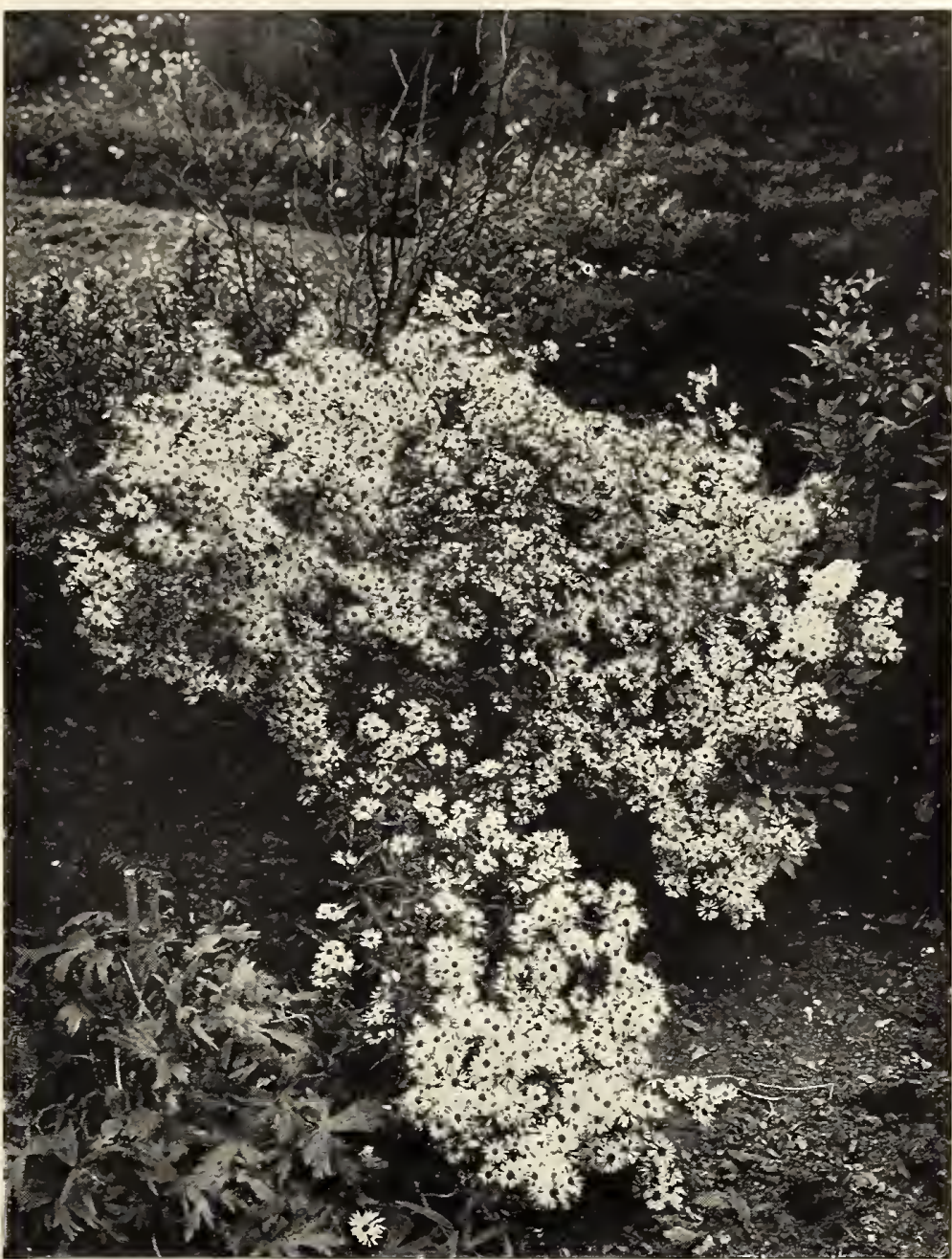

Hardy Asters are one of the glories of autumn. They sbould be liberally planted in every available space

May the Irises begin, followed closely by the Peonies; hard upon them come Delphiniums, Foxgloves and Canterbury Bells. Before one can catch his breath the Hollyhocks are upon him, then the Phloxes, the Hardy Asters, the Monkshood, and the Chrysanthemums.

Of course, this is a very meagre list. It merely records the perennials most commonly relied upon at certain seasons. If we leave March and April to the bulbs and most of May to the shrubs, June to Irises and Peonies, July to DeIphiniums, August to Phlox, September to Asters, and October to Chrysanthemums, we will be sure of flowers all season; and their ranks may be augmented and supported by hosts of retainers and substitutes.

\section{Habit of Plants}

There is a somewhat definite law, or rather practice, in gardening that taller plants should be at the back of a bed or border and smaller ones in front. As a rule, it is good. But there is lots of 


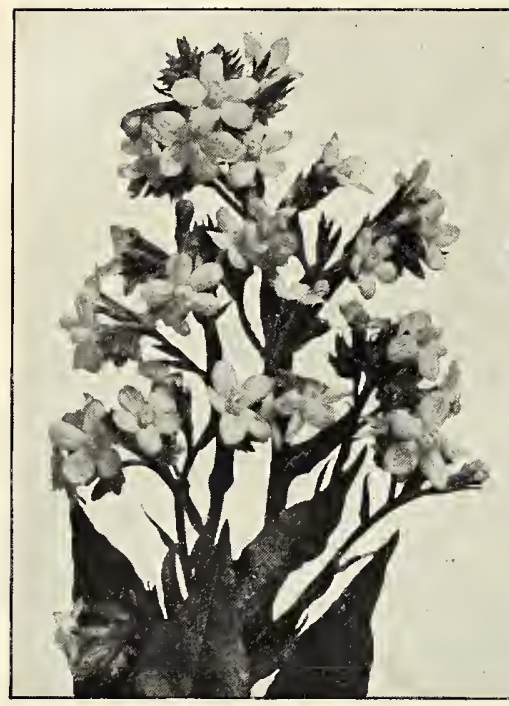

Ancbusa is unutterably blue

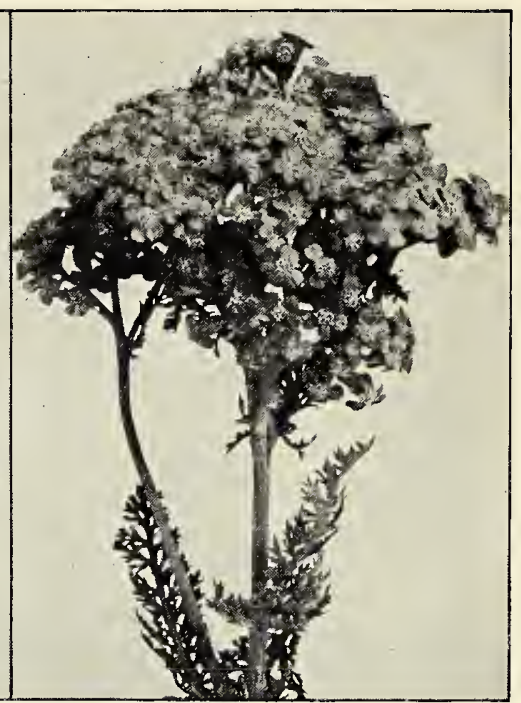

Acbillea, Cerise Queen, makes a good cut-flower

fun in breaking rules, and very fine effects are sometimes achieved by allowing very tall plants to stand at the front of the border, provided that there are no interesting flowers of dwarfer habit in bloom behind them at the time. The proper placing of plants depends so much upon individual taste and upon the contour of the ground, shrubs, trees, and other permanent plants already in the garden, that general discussion of the matter is more or less futile. Study the habits of the plants and figure out yourself where they will look best. It is much more exciting to have a garden which you have planned yourself, even if it is full of mistakes, than to follow a cut-and-dried pattern cut out by some bored landscape architect or devised by some horticultural know-it-all.

Learn to know that Hollyhocks, Delphiniums, Foxgloves, Monkshood are tall, spire-like plants; and that some of us find

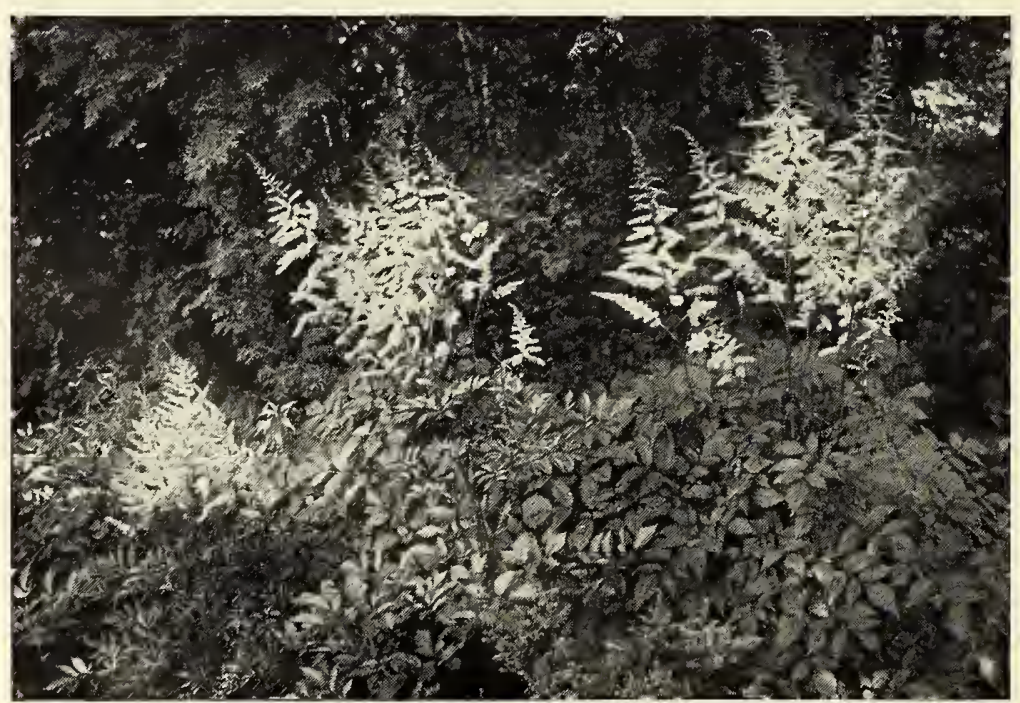

Half sbade suits the Astilbes and furnisbes a background for their featbery sprays

\section{Calimeris - Calimeris}

Calimeris. Calimeris incisa. Showy, aster-like plants of great beauty. White or purplish flowers with yellow centers. August, September. $2 \mathrm{ft}$.

\section{Camomile - Anthemis}

Kelway's Marguerite. Anthemis tinctoria (kelwayi). Brilliant, golden yellow, daisy-like flowers; excellent both in the border and for cutting. June, July. 2 to $3 \mathrm{ft}$.

\section{Carnation - Dianthus}

Giant Long-stemmed American. Diantbus caryopbyllus. A fine garden strain of the Carnations seen in the florists' shops, with large, fragrant, elegantly fringed and frilled flowers of many colors. June, July. 18 to $24 \mathrm{in}$.

\section{Cassia - Cassia}

American Senna. Cassia marilandica. Handsome plants with foliage like an acacia. Yellow, pealike flowers. July, August. 3 to $4 \mathrm{ft}$.

\section{Catananche - Catananche}

Cupid's DART. Catanancbe cærulea. Large, blue, daisy-like flowers on slender stems. Useful for cutting and sometimes used as an everlasting. June-August. $2 \mathrm{ft}$.

White Cupid's Dart. C. cærulea (alba). The same, with white flowers.

All plants above, except where noted, are 25 cts. each, $\$ 2.50$ for 12 , $\$ 18$ per 100 . Six of one kind sold at the 12 rate; 50 of one kind at the 100 rate.

\section{Chrysanthemum}

One of the most difficult things in a garden is to prolong the flowering season until really hard, freezing weather arrives. The Hardy Chrysanthemums are the gardener's best ally in this enterprise. They succeed with very little effort, withstanding a large measure of neglect, but when October and November come, you will be conscience-smitten if you have not done your best for them, when you see how magnificently they repay indifferent treatment. The family is large, and only the types commonly called Chrysanthemums are listed here.

Varieties of Cbrysantbemum coccineum will be found under Pyrethrum, and $C$. maximum under Shasta Daisy.

\section{Plants, $\$ 2.25$ for $12, \$ 14$ per 100}

Autumn Glory. Beautifully formed flowers of rich golden yellow, with brownish tinted centers.

CAPT. R. H. Cook. Tall, rather small-flowered variety of rich, dark flesh-pink, with the petals fringed at the tips and tinted with old-gold toward the center. A favorite everywhere.

CaRmelite (Glory of Seven-Oaks). Another fine and very popular pure golden yellow variety, which blooms early and profusely.

Doris. Fine bronzy variety with very short petals, making perfect, compact blooms. Popular.

Golden Climax. A bushy, medium-high sort with great quantities of splendid orange-yellow flowers. Rather late-blooming.

KLONDike. A true Pompon with rather small blooms of brilliant yellow. Showy and dependable.

Lillian Doty. Unquestionably the finest and most popular of all pink Pompons, and larger than most, blooming in very compact clusters. Rich fleshpink, with a cream undertone. Early, and always dependable. Tall.

Marie Antoinetre. A very dark pink flower of substance and high quality. 


\section{CHRYSANTHEMUM, continued}

Mitzı. Yellow flowers of small or mediun size, with red centers before fully open. Very attractive and decorative.

Mrs. Nellie Kleris. A darker pink than Lillian Doty, with a white undertone instead of cream. Very handsome and one of the best in masses.

NEw York. Small, button-like flowers of bright yellow and old-gold, tinged with bronze and crimson. Dwarf.

Petit Louis. Flowers large, Ioosely built, and of soft, silvery mauve-pink. Medium height.

Provence. Very early-flowering; large, double flowers of starry shape, pale pink at first but quickly turning pure white. Dwarf and bushy.

Red Butron. Dwarf, button type. Dark bronzy red. Early flowering and very decorative.

RED Doty. Lillian Doty type, rosy gray on outside and dark crimson within. Splendid habit, and profuse bloomer. One of the best red varieties.

Rose Trevenna. A large-flowering type, with deep rose-pink flowers. Midseason; moderate height.

Sкıво. A bright yellow variety of medium size, occasionally tinted rust-red in center.

VArsity. Button type. Early; rich deep yellow.

White Dотy. Exactly like Lillian Doty in shape of flower, but clusters more compact, and pure creamy white, almost cream-yellow in the center. Early flowering, very dependable, and handsome.

LARGE-FLOWERING VARIETIES. These are similar in habit to the foregoing, but the flowers are larger and looser in structure. They are very decorative. We offer them in three distinct shades: White, Pink, and Yellow.

Price of Chrysanthemums. $\$ 2.25$ for $12, \$ 14$ per 100

\section{Clematis - Clematis}

Ground Clematis. Clematis recta. A dwarf vine, reaching about 2 feet, forming a massed mound of foliage, covered with small white flowers in June and July. 30 cts. each, \$3 for $12, \$ 20$ per 100 .

INTEGRIFOLIA. C. integrifolia. Of similar habit, with drooping, bell-shaped flowers, dark blue outside and light blue within. June, July. $2 \mathrm{ft}$. 30 cts. each, $\$ 3$ for $12, \$ 20$ per 100 .

Climbing Clematises. See under Hedges and Vines, page 26.

\section{Columbine - Aquilegia}

Altal. Aquilegia glandulosa. Large, nodding, blue and white flowers with short, curved spurs. May, June. 12 to 18 in.

Californian. A. formosa truncata. An attractive species a little larger than the wild red Columbine, and useful for the same purpose. Flowers bright red and yellow. May, June. $1 \mathrm{ft}$.

Common Columbine. A. vulgaris. The oldfashioned, white, pink, and purple, short-spurred variety seen in old gardens. June, July. 1 to $2 \mathrm{ft}$.

Golden-spurred. A. cbrysantba. Very beautiful, long-spurred, pale yellow. May, June. 3 to $4 \mathrm{ft}$.

Golden-SPURRED, White. A. cbrysantba. A white-flowered form. May, June. 3 to $4 \mathrm{ft}$.

LONG-SPURRED HYBRIDS. A choice selection of many colors of excellent habit and great beauty. May, June. 3 to $4 \mathrm{ft}$.

Mexican. A. skinneri. Handsome, red flowers, tipped orange. July-September. 1 to $2 \mathrm{ft}$.

All plants on this page, except where noted, are $25 \mathrm{cts}$. each. $\$ 2.50$ for $12, \$ 18$ per 100 . Six of one kind sold at the 12 rate; 50 of one kind at the 100 rate.

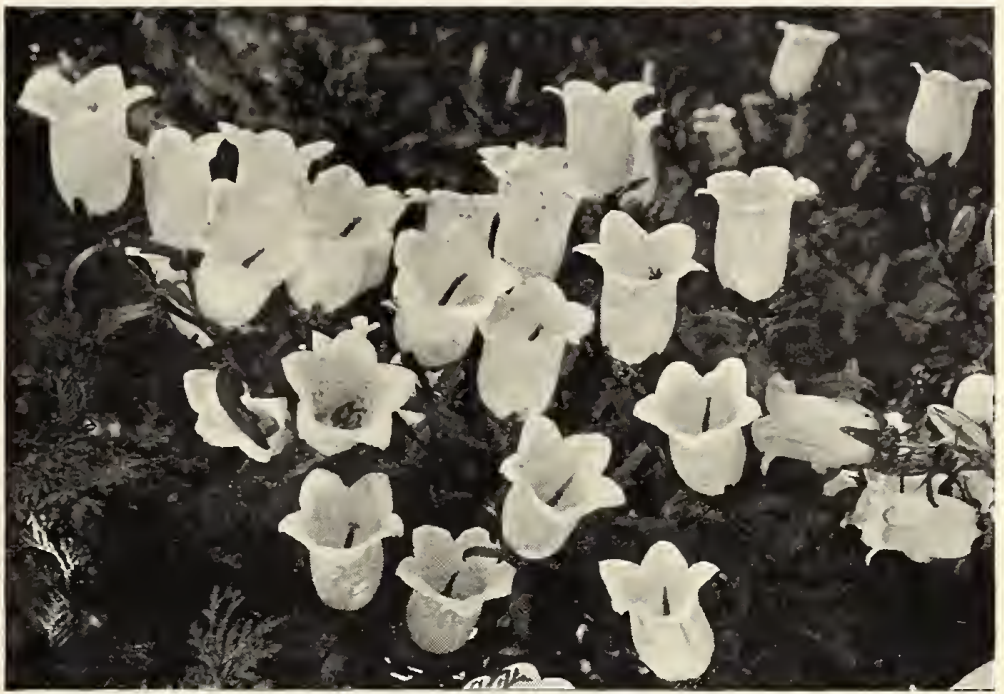

Canterbury Bells are exquisite, even when the plant bas fallen over, as this one bas. They are more stately when staked erect

Hollyhocks jolly, Delphiniums inspiring, Foxgloves quaint, and Monkshood mysterious; and that we put Hollyhocks near our gates and our doorways for their cheerful welcoming, come-in-andsee-us air; that we put the Delphiniums in a quiet place against a background of green where one may contemplate their heavenly color undisturbed. We put Foxgloves with Sweet Williams and other old-fashioned flowers; and we hide the Monkshood under trees in dark and shadowy places where they may be rather furtively sought in the chilly evenings of autumn.

Thus, you see, that though we class all of them as tall, spirelike plants, they are not alike at all; and you must experiment a while before you find out just how best to use them.

Considering the possibilities in just these few plants, what

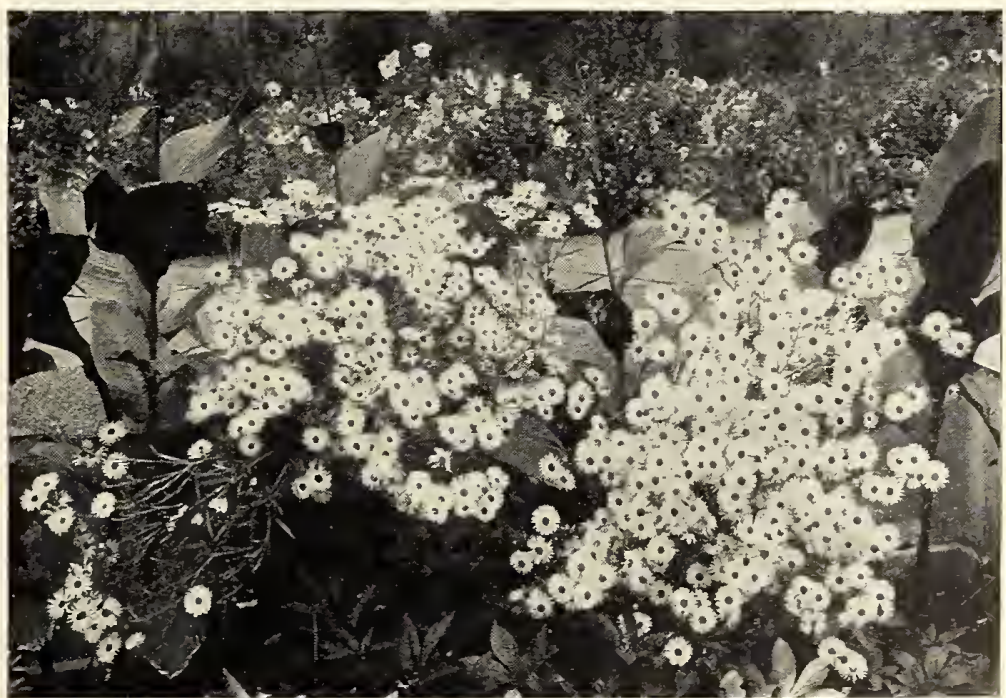

Violet Boltonias are mucb like bardy asters in effect, but are more amenable in babit 


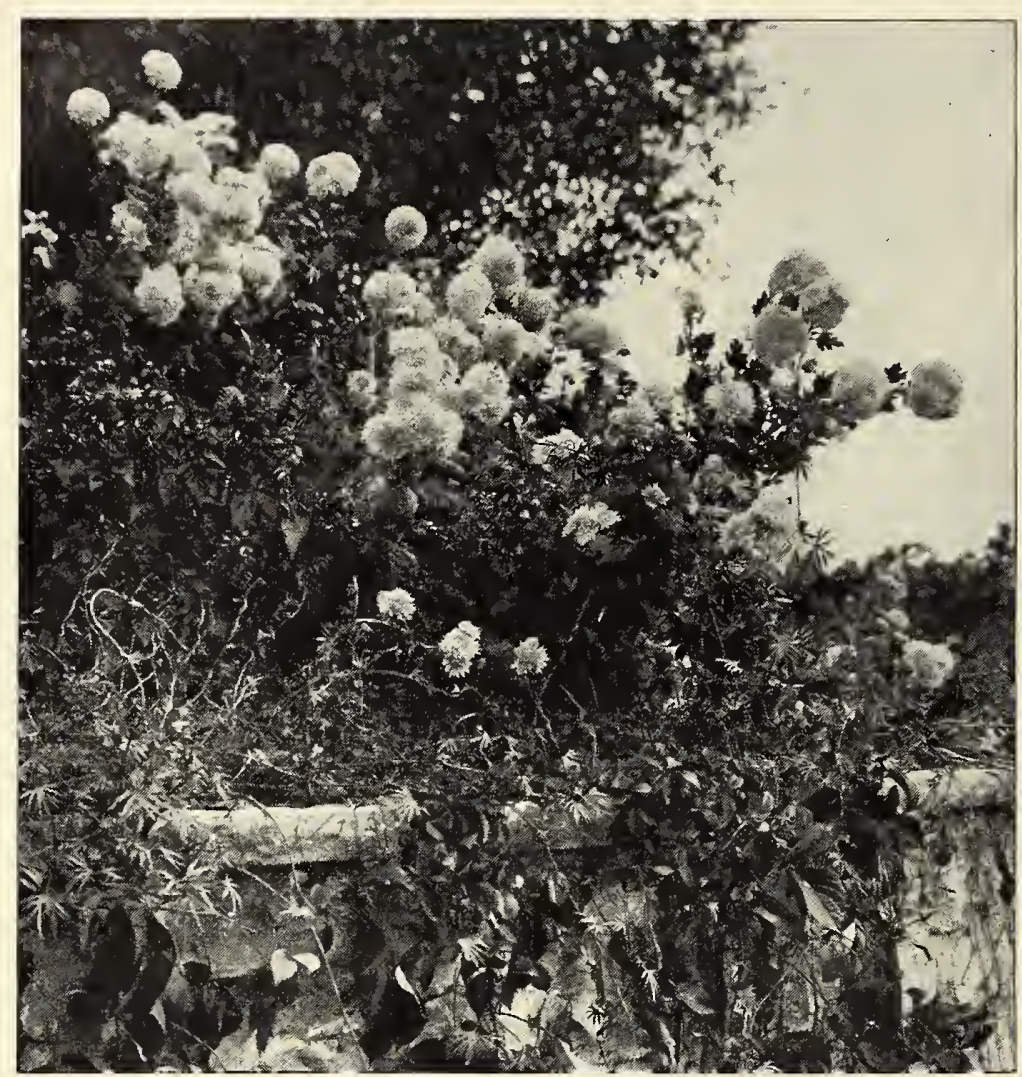

Cbrysanthemum, Lillian Doty, makes this garden gay after the frosts bave killed all other flowers

endless vistas of interesting adventure lie before you in exploring their varieties, in trying out new types of each kind, new colors and new combinations of old and new! Besides, you have not exhausted the list of similar plants. What shall we do with Cimicifuga racemosa (Bugbane), for instance? Where will its slender, lofty stems and yard-long tassel of foamy white be most happy and most effective? Where shall we place the highly ornate foliage and the graceful, drooping seed-pods of the Plume Poppy (Bocconia cordata)? Do we have room for the sturdy grace of the Greek Mullein (Verbascum olympicum), for the lofty, downy sprays of the Feather Fleece (Stenantbium robustum), for the slender, wedgelike spikes of the False Dragonhead (Physostegia virginiana), for the stately, formal grandeur of Adam's Needle (Yucca flamentosa), for the erratic, upward-swinging rockets of the Kansas Gayfeather (Liatris pycnostachya), and so on, and so on?

Besides these, we have the tall, bushy Perennials. Things like Hardy Asters which spread and spread, forming great, mounded masses covered with myriads of purple-blue and Iilac stars. These are typical background plants, wedged in little cracks in the shrubbery border where they will make a glory high above the lower shrubs, or they may form a bank at the far edge of a sweep of lawn, merging their color with the blue mists of autumn, lending enchantment and mysterious distance to the tiniest plot. The tall, brazen beauty of the Golden Glow (Rudbeckia laciniata), the Sunflowers (Heliantbus), and the Heleniums-aIl flowers of Iate
COLUMBINE, continued

Mrs. Scott Elliott Hybrids. The choicest types of long-spurred forms in a very wide range of color. May-July. 3 to $4 \mathrm{ft}$. 30 cts. each, $\$ 3$ for $12, \$ 20$ per 100 .

Orympica. A. vulgaris. A fine, pale violet form of the Common Columbine. May, June. 18 to 24 in.

Otber Columbines described in Rock Garden Section, page 45

\section{Coreopsis - Coreopsis}

Coneopsis. Coreopsis grandiflora. Very large, bright golden yellow flowers on wiry stems, excellent for cutting. July-September. 1 to $2 \mathrm{ft}$.

\section{Day Lily - Hemerocallis}

Apricot. Hemerocallis bybrida. A new variety of exquisite apricot color. June, July, 2 to $3 \mathrm{ft}$.

Citrea. Citron-yellow.

DWarF Day Lily. $H$. minor. Flowers golden yellow, fluted and waved. July, August. 15 to 18 in.

EARLy Day Lily. $H$.dumortieri. The earliest to bloom. Bright orange-yellow flowers. May, June. 15 inches.

FloRhAM. $H$. bybrida. A strong-growing variety with deep golden yellow flowers very freely produced in June and July. $3 \mathrm{ft}$. or over.

Golden Day Lily. $H$. luteola. A strong, tall sort, with shapely yellow-orange flowers. July. $3 \mathrm{ft}$.

Kwanso. H. fulva. A double-flowering form of the common Tawny Day Lily. July, August. 4 to $5 \mathrm{ft}$.

Lemon Lily. H. flava. The tall, favorite, sweetly scented, pale yellow variety. One of the finest. May, June. $3 \mathrm{ft}$

Ochroleuca. $H$. bybrida. Tall, very strong, erect stems with crimped, handsome flowers of light yellow with sweet lemon-like odor. July, August. $3 \mathrm{ft}$.

Orange. $H$. aurantiaca. Dark, glowing orange, sweet-scented flowers. July, August. 30 to 36 in.

\section{Delphinium • Delphinium}

Belladonna. A very beautiful and useful garden type, with branching stems bearing widely spaced, delicately blue flowers with creamy white eyes. The most popular for cut-flowers and for mixed planting. June, July. 3 to $4 \mathrm{ft}$.

Bellamosum. Delpbinium formosum. A hybrid variety of rich dark blue, somewhat like Belladonna in habit, but taller and of stronger growth. Very desirable. June, July. 4 to $5 \mathrm{ft}$.

Improved ENGLish HyBrids. Marvelous new creations which arouse wonder and admiration everywhere. Wonderful plants of magnificent habit with stout stems from 4 to 6 feet tall, bearing spikes of handsome flowers in every shade of blue, violet, and lavender imaginable. We offer:

Extra-selected Varieties. The cream of the lot. 50 cts. each, $\$ 5$ for 12.

Fine Mixed. Grown from seed of famous named varieties. $\$ 2.50$ for $12, \$ 18$ per 100 .

Selected Varieties. Especially picked plants from thousands of seedlings grown from the finest named sorts. $35 \mathrm{c}$. each, $\$ 3.50$ for $12, \$ 23$ per 100 .

\section{Echinacea - Echinacea}

Purple Coneflower. Ecbinacea purpurea. Stout, tough plants, bearing large, rosy purple, daisylike flowers with drooping petals around a purplebrown cone in the center. July, August. 2 to $3 \mathrm{ft}$.

All plants on this page, except where noted, are $25 \mathrm{cts}$. each, $\$ 2.50$ for $12, \$ 18$ per 100 . Six of one kind sold at the 12 rate; 50 of one kind at the 100 rate. 


\section{Echinops · Echinops}

Globe Thistle. Ecbinops ritro. Coarse, thistlelike plants for backgrounds and between shrubs. with striking ball-like flowers of intense steel-blue. July-September. 4 to $6 \mathrm{ft}$.

\section{Evening Primrose - Enothera}

Fraser's Sundrops. Enotbera glauca. Tall, imposing plants with very large, bright yellow flowers open only in sunshine. July. 3 to $4 \mathrm{ft}$.

Pink Sundrops. $E$. speciosa (rosea). A lower plant with very large, saucer-like, whitish or pale pink flowers of great beauty that open only in sunlight. July. $2 \mathrm{ft}$.

Otber Sundrops are described in tbe Rock Garden Section, page 45.

\section{Foxglove - Digitalis}

Common. Digitalis purpurea. Stately plants with spires of large, pale violet flowers, spotted with purple, in various shades. June, July. 4 to $5 \mathrm{ft}$.

Common White. $D$. purpurea (alba). White flowers sometimes faintly spotted.

Gloxinia-Flowered. D. purpurea. Handsome, large flowers of pure white, spotted with crimson, rose, and purple. June, July. 4 to $5 \mathrm{ft}$.

LEOPARD-FLOWERED. D. purpurea (maculata superba). Very distinctly marked and spotted flowers in shades of red, bue, purple, and similar tints. June, July. 4 to $5 \mathrm{ft}$.

SHIRLEY. D. purpurea. The finest, tallest strain, with extremely large and very handsome flowers. Well-grown, established plants will reach 8 feet and will bloom over an exceedingly long season.

Yellow Foxglove. D. lutea (grandiflora). True perennials, with large, lipped, straw-yellow flowers of great beauty. June, July. 2 to $3 \mathrm{ft}$.

\section{Gaillardia • Gaillardia}

IMPROVED. Gaillardia aristata. Gold and orangered flowers of great boldness and beauty. Fine for cutting. July-September. $2 \mathrm{ft}$.

Portola Hybrids. G. aristata. Larger flowers than the type with fine clear crimson greatly predominating in the color. July-September. $2 \mathrm{ft}$. 30 cts. each, $\$ 3$ for $12, \$ 20$ per 100 .

\section{Geum • Geum}

Avens. Geum cbiloense (atrosanguineum). Erect plants with brilliant scarlet-orange flowers like little roses. May-July. 1 to $2 \mathrm{ft}$.

Lady Stratheden. G. cbiloense. Large, double, brilliant orange flowers. June-September, $2 \mathrm{ft}$.

Mrs. Bradshaw. G. cbiloense. Dark red, very Iarge double flowers. June-September. $2 \mathrm{ft}$.

\section{Goatsbeard • Aruncus}

Common. Aruncus sylvester. Bold-leaved plants with panicles of white flowers somewhat similar to the astilbes. Useful in shade, although does best in an open situation. June, July. 3 to $4 \mathrm{ft}$. $30 \mathrm{cts}$. each, $\$ 3$ for $12, \$ 20$ per 100 .

\section{Grasses • Gramineæ}

Blue Fescue. Festuca glauca. Tufted silvery gray grass, useful for edgings and borders. 1 to $2 \mathrm{ft}$.

Chinese Fountain Grass. Pennisetum alopecuroides (japonicum). Fountainlike grass, with bright green leaves and large heads of purplish flowers. 2 to $4 \mathrm{ft}$

All plants on this page, except where noted, are 25 cts. each, $\$ 2.50$ for 12 , $\$ 18$ per 100 . Six of one kind sold at the 12 rate; 50 of one kind at the 100 rate.

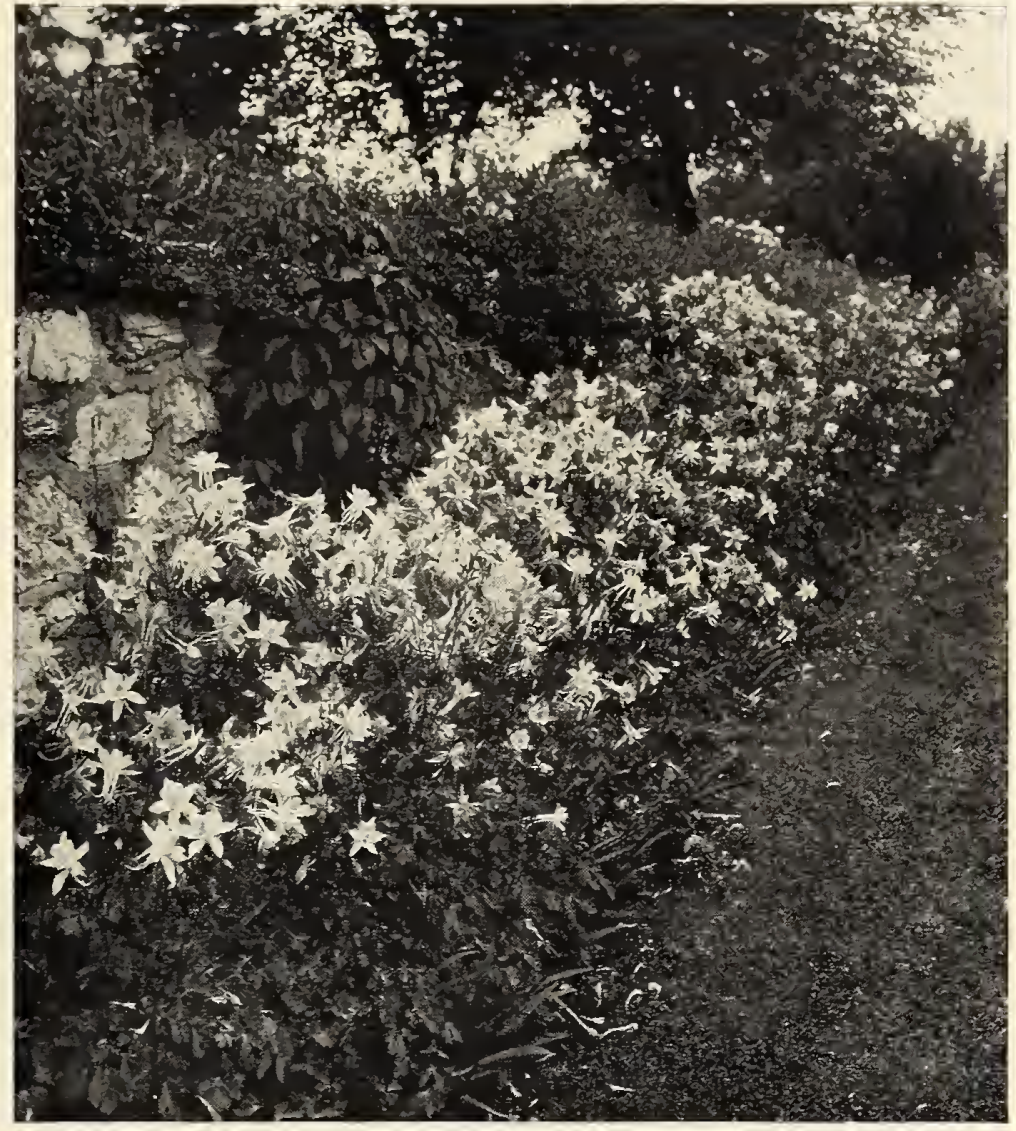

All flowers yield to the grace and delicacy of Columbines. A planting of Long-spurred Hybrids below a wall

summer and autumn, too coarse for intimate pleasure but marvelous when properly placed in the landscape so that their smashing colcrs leap from point to point along the beds and borders, leading the eye away from the bare places where plants have passed out of bloom or failed.

One of the most effective flowers for this same purpose is the Mallow, or the Mallow Marvels, as gardeners call them, with tall, spreading stems, big, broad leaves, and enormous, fluted flowers of impossible size, like mightily magnified Hollyhocks. A really fine thing about them is their range of color-white, pink, and crimson -hues which are rare in late summer and autumn when most plants are bedecked in purple and gold. They, also, need distance to be most effective because, close up, the flowers are simply overwhelming, and it would be a bold person who cut them and tried to live with a vase full of them in his living-room.

\section{Medium Height}

Plants of this group range from one to four feet high. Here are Peonies, Irises, and Phlox, three of the most important garden plants, and the Chrysanthemums, which are indispensable if one is not content to see the garden bare after the first frost. Peonies and Irises are treated in separate sections of this book. Of the 
Phloxes, the most valuable of all is the rather dwarf, early-flowering Miss Lingard. No garden ever has enough of it. It is one of the most satisfactory white flowers, of which a good many are needed, if there is to be grace, airiness, and comfort in the garden. As to other Phloxes, it is almost immaterial which varieties are chosen as long as you consult your own preferences in color and avoid disagreeable clashes. Generally, the pink Phloxes tend to become magenta as they age, unless salmon shades are chosen, and one must be very particular about weeding out seedlings if colors are to be kept true. Phloxes seed very readily, and the seedlings resemble offshoots of the old plants so closely that people often say that their Phloxes revert to the old magenta colors, when the fact is that inferior seedlings have crowded out their parents, and not that the original stock has deteriorated.

Every garden ought to have a fine assortment of Phloxes. There are a great many named varieties, much alike in color, but differing in height, size of flower, proportion and size of the head, and time of blooming. These things must be taken into consideration, and a proper selection of early-, medium-, and lateflowering types planted to insure the longest possible season of bloom; for the Phloxes are the great bridge which carries the garden through the heats and droughts of summer when the spring-

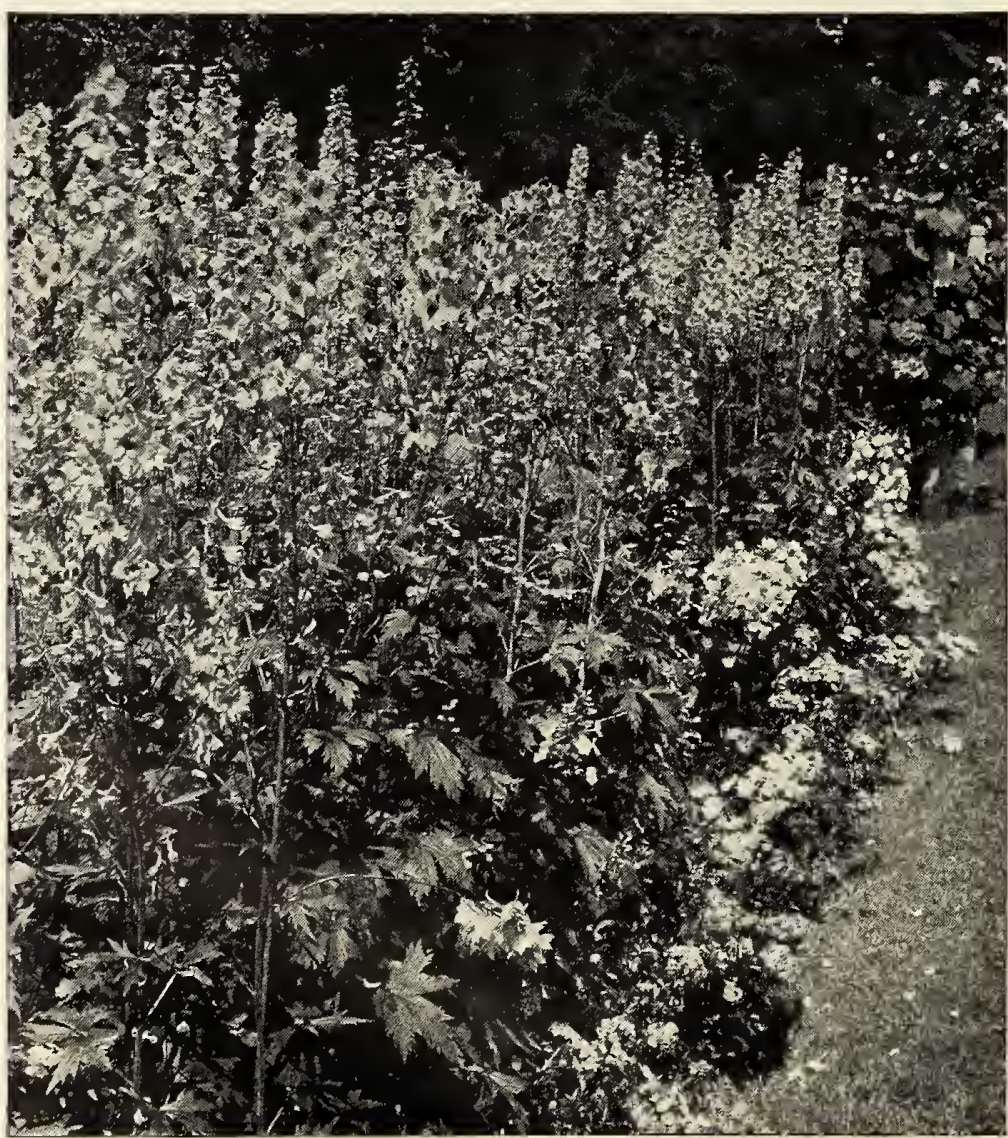

Extra-selected varieties of Delpbinium make a glorious display. The plants in front are Pblox, Miss Lingard, and Newport Pink Sweet Williams

\section{GRASSES, continued}

Eulalia. Miscantbus sinensis. Bold, foliage plant with tall, feathery panicles of bloom. September. 6 to $9 \mathrm{ft}$.

Maiden Grass. M. sinensis (gracillima). Very graceful Grass, surmounted in autumn with large, feathery plumes which may be dried for winter bouquets. 4 to $5 \mathrm{ft}$.

Striped Eulalia. $M$. sinensis (variegata). The long leaves are marked with white stripes. 4 to $5 \mathrm{ft}$.

Striped OAt-Grass. Arrbenatberum bulbosum (variegatum). An erect, decorative, fountain-like plant with narrow striped leaves. 2 to $4 \mathrm{ft}$.

Zebra Grass. $M$. sinensis (zebrina). Leaves barred with yellowish cross-stripes. Very striking. 4 to $5 \mathrm{ft}$.

\section{Gypsophila • Gypsophila}

Baby's Breath. Gypsopbila paniculata. The common variety, making a fine mistlike mound of tiny white flowers in great sprays. June, July. 2 to $3 \mathrm{ft}$.

Baby's Breath, Double. G. paniculata ( $f$.-p $l$.). Flowers are double, whiter, and larger than above. June, July. 2 to $3 \mathrm{ft}$.

Baby's Breath, Pink. G. perfoliata. Taller than the other varieties, with sprays of tiny, purplish pink flowers. June, July.

Bristol FaIRy. G. paniculata. A greatly improved double variety with great sprays of very double, intensely white flowers, produced all season. Lovely for mixing with bouquets of other flowers. June-November. 2 to $3 \mathrm{ft}$. $\$ 1$ each.

\section{Helenium • Helenium}

Great Sneezewort. Helenium autumnale (superbum). Erect plants with showy orange, crimson, and yellow flowers. August, September. 3 to $4 \mathrm{ft}$.

Orange SneEzewort. H. boopsei. Fine flowers of rich orange, excellent for cutting. May, June. 2 to $3 \mathrm{ft}$.

\section{Heliopsis - Heliopsis}

B. LadHams. Heliopsis belianthoides. A fine, largeflowered variety of this false Sunflower. Very effective in the border. August, September. 3 to $4 \mathrm{ft}$.

Pitcheriana. $H$. belianthoides (pitcberiana). A dwarf form with large, deep yellow flowers. August-October. 2 to $3 \mathrm{ft}$.

\section{Hollyhock • Althæa}

Indispensable, stately plants for landscape effect and for backgrounds of borders. July, August. 5 to $8 \mathrm{ft}$.

Best Large-flowered Single. Altbæa rosea. A selection of the finest single-flowering types,

Best Large-flowered Double. A. rosea. All colors mixed.

Chater's Famous Strain. A. rosea. Double flowers, in separate colors. A very choice strain selected for size of flower, stateliness of habit, and brilliance of color.

New Allegheny. A. rosea. Immense, half-double flowers, with fringed and frilled edges. Very beautiful.

Iris - Iris

See Special Section, page 37.

All plants on this page, except where noted, are $25 \mathrm{cts}$. each, $\$ 2.50$ for $12, \$ 18$ per 100 . Six of one kind sold at the 12 rate; 50 of one kind at the 100 rate. 


\section{Kniphofia • Kniphofra}

These extraordinarily beautiful flowers suffer from many names. They are also called Red-Hot Poker, Torch Lily, and Tritoma.

Bonfire. Kniphofia uraria (grandis). Long spikes of tubular, orange-yellow flowers, extremely striking when grown in masses. August, September. 2 to $3 \mathrm{ft}$. 35 cts. each, $\$ 3.50$ for $12, \$ 25$ per 100 .

Everblooming Hybrids. K. bibrida. Conspicuous, handsome plants with long spikes in shades of orange, yellow, and scarlet. July-October. 2 to $3 \mathrm{ft}$. 30 cts. each, $\$ 3$ for $12, \$ 20$ per 100 .

\section{Lavender • Lavandula}

SWEET LAVENDER. Lavandula officinalis. The true old favorite blue flower, dried for its delicious fragrance. July-September. 18 in.

\section{Lespedeza - Lespedeza}

Bush Clover. Lespedeza formosa. Showy, almost shrubby plant, with clusters of purple-red, pealike flowers. July, August. 3 to $4 \mathrm{ft}$. $60 \mathrm{cts}$. each, $\$ 6$ for 12 .

\section{Liatris - Liatris}

Callilepsis. Liatris callilepsis. Bright, purple-red flowers in long spikes. July-September. 3 to $4 \mathrm{ft}$.

Kansas Gayfeather. L. pycnostacbya. Tall spikes of rich purple, fringed flowers, blooming from the top down. July, August. 3 to $5 \mathrm{ft}$.

Lily • Lilium

See Special Section, page 41.

Lily-of-the-Valley • Convallaria

Lily-of-the-VAlley. Convallatia majalis. Dainty, waxen bells of supreme fragrance. A good groundcover for shady places. May. 6 to 8 in. $\$ 1$ for $25, \$ 3.50$ per 100 .

\section{Lupine - Lupinus}

ElliotT's SWEET-sCENTED. Lupinus polypbyllus. Select plants of the choicest types, all deficately fragrant. Blue, Rose, and White. June, July. 2 to $3 \mathrm{ft}$. 30 cts. each, $\$ 3$ for $12, \$ 20$ per 100 .

W ASHINGTON, L polypbyllus. The common garden Lupine, of bushy habit, with spikes of pea-like, dark blue flowers. May, June. 2 to $3 \mathrm{ft}$. $30 \mathrm{cts}$. each, $\$ 3$ for $12, \$ 20$ per 100 .

White or Pink. L. polypbyllus (albus and roseus). Selected varieties of the Washington Lupine with white or pink flowers. Either color, 30 cts. each, $\$ 3$ for $12, \$ 20$ per 100 .

\section{Lychnis - Lychnis}

MAltese Cross. Lycbnis cbalcedonica. Stiff plants with heads of vivid scarlet flowers. Very showy. July, August. 3 to $4 \mathrm{ft}$.

Mullein Pink. L. coronaria. Gray foliage of great beauty. Plants branching, covered with circular, brilliant crimson flowers. June, July. 12 to 18 in. Also to be had with White (alba) and Dark Red (atrosanguinea) flowers.

Otber Lycbnis described in Rock Garden Section, page 47

\section{Lysimachia - Lysimachia}

JAPANESE LOOSESTRIFE. Lysimacbia cletbroides. Upright plants, with spikes of white, starry flowers. Good for cutting. July-September. 2 to $3 \mathrm{ft}$.

Otber Loosestrifes described in Rock Garden Section, page 47 All plants on this page, except where noted, are 25 cts. each, $\$ 2.50$ for $12, \$ 18$ per 100 . Six of one kind sold at the 12 rate; 50 of one kind at the 100 rate. blooming perennials are past and the autumn flowers have not yet arrived.

The time comes at the end of the season when only the hardiest things have survived the frost, and one may go about through the frost-bitten things with a feeling of sorrow and resignation. That time is utterly unavoidable. Winter will come. But it can be postponed by the Chrysanthemums. Strange flowers to choose such a season to bloom; and wise flowers, too, because the absence of competition gives them the opportunity to shine that no other flower enjoys. Late October, November, and in mild seasons into December, the garden may be rich with their gold and white and pink and mahogany-brown.

Because they bloom so late, one always grudges them the space they take up all season. It is not easy to reconcile oneself to the blanks in the garden where the Chrysanthemums are to flower. It is best if you can do this; plants thoroughly established in their places are always happier and more prolific than newly transplanted ones. But Chrysanthemums are so accommodating that it is quite possible to grow them all summer long in a small nursery out of sight somewhere, or in the vegetable-garden, and move them as they come into bloom to places where they will do the most good.

We have found it good practice to let them serve third turn in

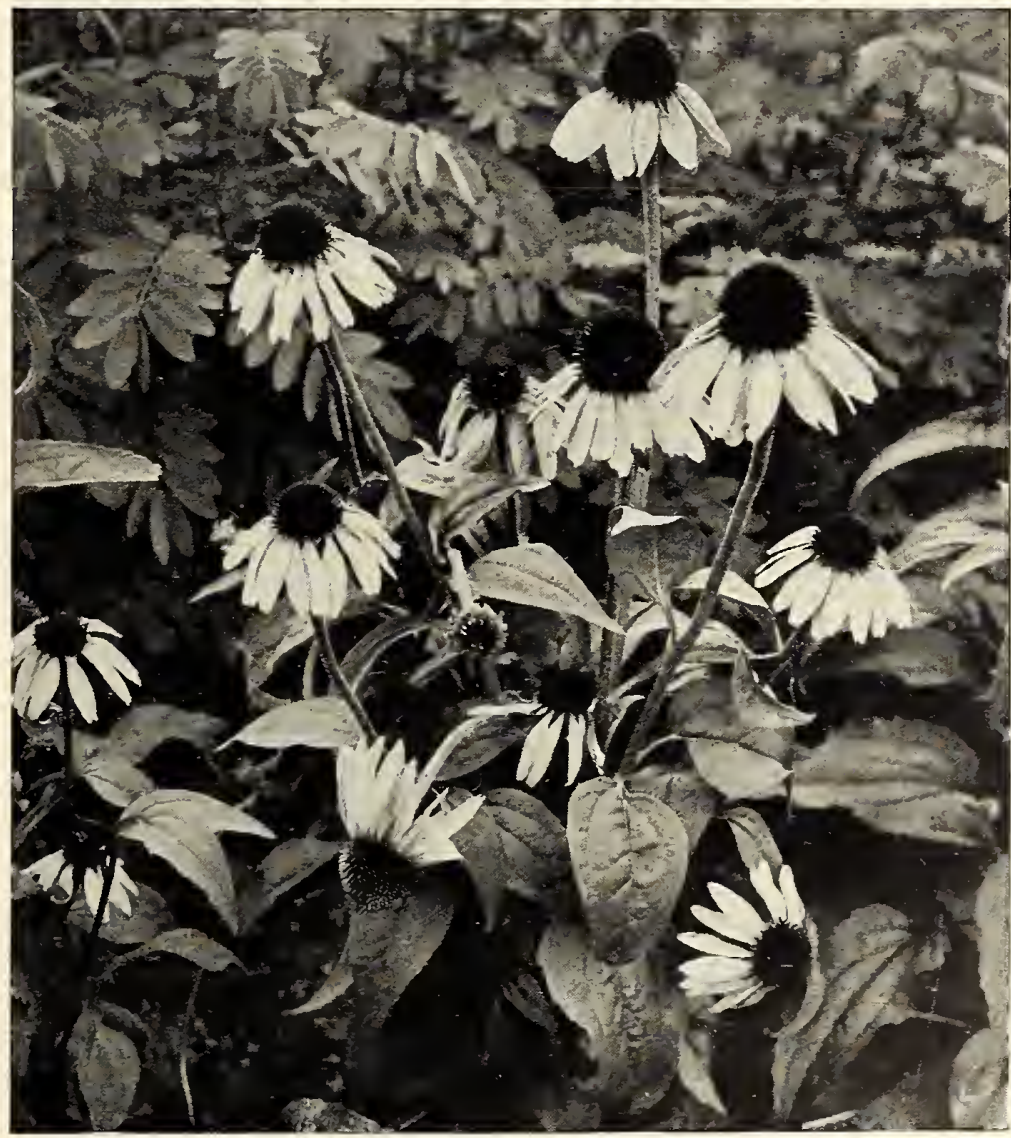

The Purple Coneflower or Ecbinacea is one of the most decorative and enduring perennials 


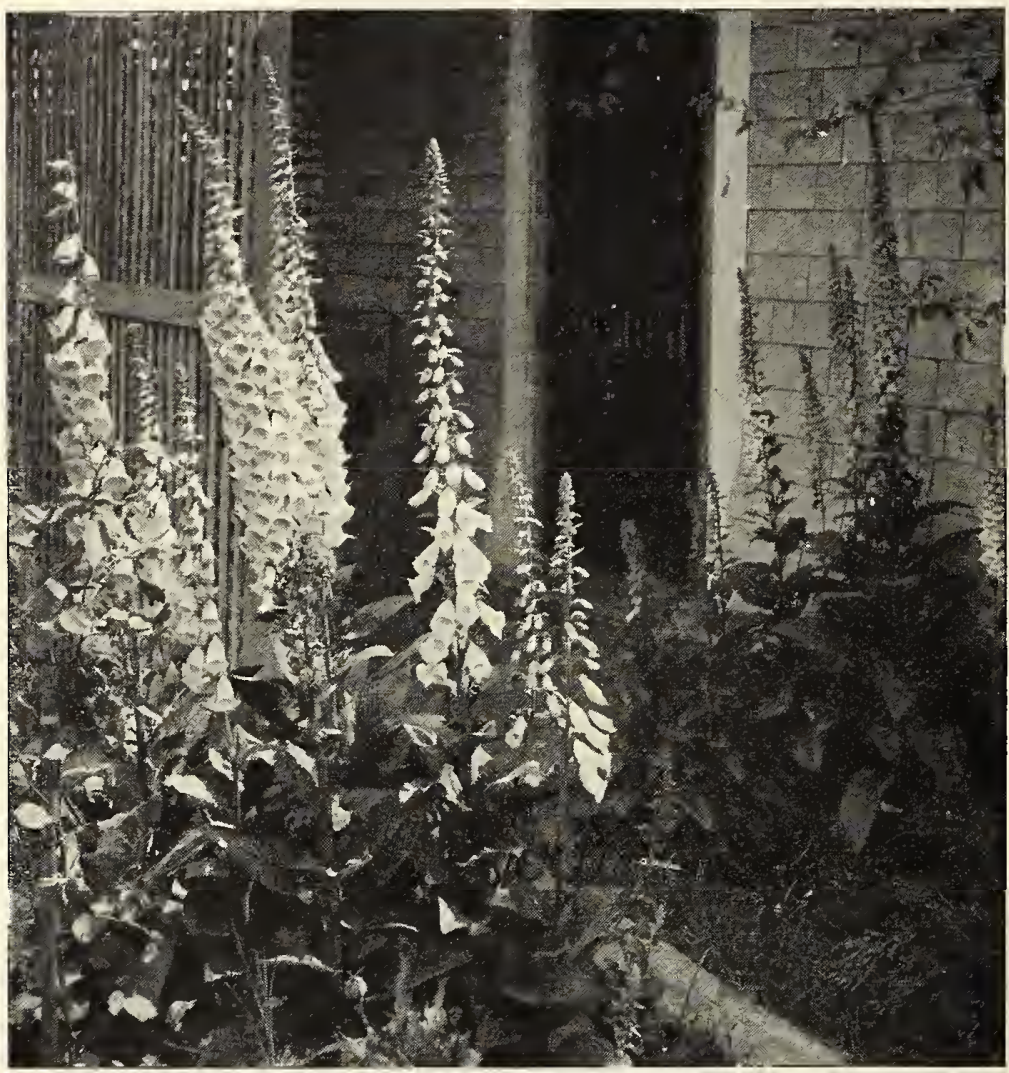

Foxgloves are equally at bome in an elaborate perennial border or by a kitchen door

a bed which was full of Tulips in the spring and radiant with annuals in the summer. If there is an abundant supply of Chrysanthemums to take the place of the annuals, one is not so likely to delay too long planting Tulips. About the middle of September, most annuals look pretty shabby, but one hates to tear them up and plant bulbs because of the bare expanse of ground left for the rest of the season.

But it is wise to throw away the annuals when they have done their best; plant Tulips, and then move Chrysanthemums in on top of them! When the Chrysanthemums are through blooming,

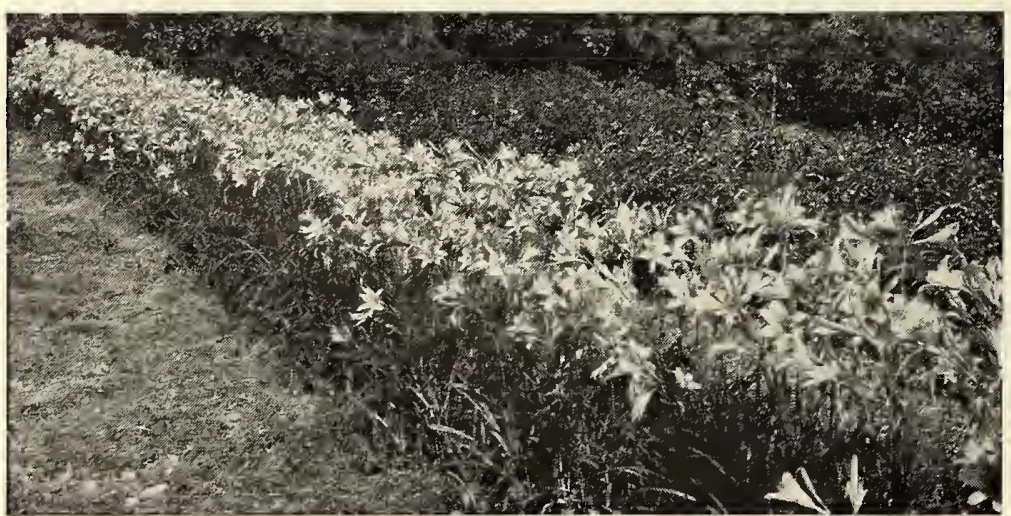

A lovely dwarf bedge of Day Lilies (Hemerocallis)

\section{Lythrum • Lythrum}

ROSE LOOSESTRIFE. Lytbrum salicaria (roseum superbum). Excellent border plant for moist places. Spikes of rich pink flowers. July, August. 2 to $3 \mathrm{ft}$.

\section{Mallow • Hibiscus}

Crimson Eye. Hibiscus oculiroseus. Immense white flowers with vivid crimson centers. Strong, bushy plants. August, September. 3 to $5 \mathrm{ft}$.

Rose Mallow. $H$. moscbeutos. Light rose-pink flowers with darker centers. Very showy and effective. August, September. 5 to $6 \mathrm{ft}$.

Rose Mallow Marvels. Hybrid varieties with grgantic flowers of almost unbelievable size, and very brilliant and showy. All the varieties listed are splendid large perennials for conspicuous situations. July, August. 5 to $7 \mathrm{ft}$.

Crimson. Giant; gorgeous red.

PINk. Variable, from light to dark pink. White. Pure white with Iarge crimson eye.

All Rose Mallow Marvels, 35 cts, each, $\$ 3.50$ for 12

\section{Meadowsweet • Filipendula}

Elegans. Fílipendula purpurea. A showy variety with foamy clusters of silvery pink flowers. June-August. 3 to $4 \mathrm{ft}$. 35 cts. each, $\$ 3.50$ for 12 , $\$ 25$ per 100.

European. F. ulmaria. Small, double, white flowers in large clusters, somewhat like a spirea or astilbe. June, July. $3 \mathrm{ft}$.

Siberian. F. palmata. Bright crimson flowers. June-August. 2 to $3 \mathrm{ft}$. $30 \mathrm{cts}$. each, $\$ 3$ for 12 , $\$ 20$ per 100 .

\section{Milkweed - Asclepias}

Butterfly Weed. Asclepias tuberosa. Extremely showy plants with blazing orange-yellow flowers in round clusters. July, August. 1 to $2 \mathrm{ft}$.

\section{Monarda - Monarda}

Bee Balm. Monarda didrma. A low, bushy plant for masses, covered with glowing scarlet flowers and having aromatic fragrance. July, August. $2 \mathrm{ft}$.

Cambridge Scarlet. M. didyma. Taller, larger, and redder flowers. July, August. $3 \mathrm{ft}$.

\section{Mullein - Verbascum}

Greek Mullein. Verbascum olympicum. BeautifuI velvety leaves and erect stalks studded with yellow flowers. July. 3 to $5 \mathrm{ft}$.

Purple Mullein. V. phorniceum. Erect plant for shady places. Flowers purple. July, August. $5 \mathrm{ft}$.

\section{Pentstemon - Pentstemon}

Torrey's. Pentstemon torreyi. Sprawling, halferect plants with long, tubular orange and red flowers, Íke fire-crackers. June, July. 2 to $4 \mathrm{ft}$.

\section{Peony - Pæonia}

See Special Peony Section, pages 34-36.

Physalis - Physalis

Japanese Lantern. Physalis francbetti. Vine-like plants with sprays of papery, orange-red fruits of great decorative quality for cutting.

All plants on this page, except where noted, are $25 \mathrm{cts}$. each, $\$ 2.50$ for $12 . \$ 18$ per 100 . Six of one kind sold at the 12 rate, 50 of one kind at the 100 rate. 


\section{Phlox • Phlox}

Arend's. Pblox arendsi. A new type similar to $P$. divaricata, growing 1 to 2 feet high, blooming in May and June. Two varieties as follows: GreTA. Pure white, occasionally tinted lilac. Helene. Clear lavender-blue. 35 cts. each, $\$ 3.50$ for $12, \$ 25$ per 100 .

HARDY PERENNIAL PHLOX ( $P$. decussata)

The one standby of the gardener for showy color in late summer when the garden is likely to be otherwise barren. Plant them liberally in broad masses, keeping varieties of similar color together.

All varieties. $\$ 2.50$ for 12 . $\$ 15$ per 100 , except where noted

A. G. McKmmon. Lilac; very large; early.

Albion. White, faint red eye.

Antonin Mercie. Lilac-blue, with white eye; large. Athis. Salmon-pink; taller than most.

Baron von Heckeren. Salmon-pink; very large.

B. Comte. Dark purple-red or amaranth.

BEACON. Brilliant cherry-red. 30 cts. each, $\$ 3$ for $12, \$ 20$ per 100.

Duguesclin. Dark rose-pink, mauve at edges.

Eclaireur. Crimson-purple, with white center.

Europa. White, with large crimson eye.

Frau Antoine Buchner. Pure white; large trusses. GolratH. Light crimson, with dark red eye.

Jules Sandeau. Pure pink. Dwarf. $30 \mathrm{cts}$. each, $\$ 3$ for $12, \$ 20$ per 100 .

Kossutr. Dark rose-pink, with maroon center.

La Vague. Pale silvery rose-pink.

Miss Lingard. Dwarf, early, and almost continuous flowering. An extremely useful pure white variety

Mrs. Jenkins. Pure white; long season.

Mrs. Scholten. Dark salmon-pink. 30 cts. each, $\$ 3$ for $12, \$ 20$ per 100 .

Paladin. Salmon-pink, with cerise eye and edges. 30 cts. each, \$3 for 12 , \$20 per 100.

Richard Wallace. White with violet eye.

Rijnstroom. Brilliant rose-pink.

Riverton Jewel. Mauve with crimson eye.

THOR. Salmon, suffused with scarlet.

WIDAR. Light red-violet with white eye.

\section{Physostegia - Physostegia}

False Dragonhead. Pbysostegia virginiana. Rigid, upright, background plants, with spikes of pinkish white flowers. July, August. 5 to $6 \mathrm{ft}$.

White. $P$. virginiana (alba). Flowers pure white.

Сомраст. $P$. virginiana. Low-growing; flowers charming pink.

\section{Pink • Dianthus}

JaPANese Pink. Diantbus beddewigi. Erect, tufted plants with very large, fringed flowers in dazzling array of shades of red, pink, crimson, striped, marbled, starred, and fretted in the most marvelous way. June-August. $1 \mathrm{ft}$.

\section{Plantain Lily - Hosta}

Aokı. Hosta sieboldiana. Dwarf, with pale blue flowers. Foliage large, bluish green.

Blue. $H$. cxrulea. Broad green leaves and bright blue, nodding flowers. June, July. 12 to $18 \mathrm{in.}$

Golden Spotred. H. plantaginea (aurea maculata). Bright yellow leaves, gradually becoming greenish. Flowers white.

All plants on this page, except where noted, are $25 \mathrm{cts}$. each, $\$ 2.50$ for $12, \$ 18$ per 100 . Six of one kind sold at the 12 rate: 50 of one kind at the 100 rate.

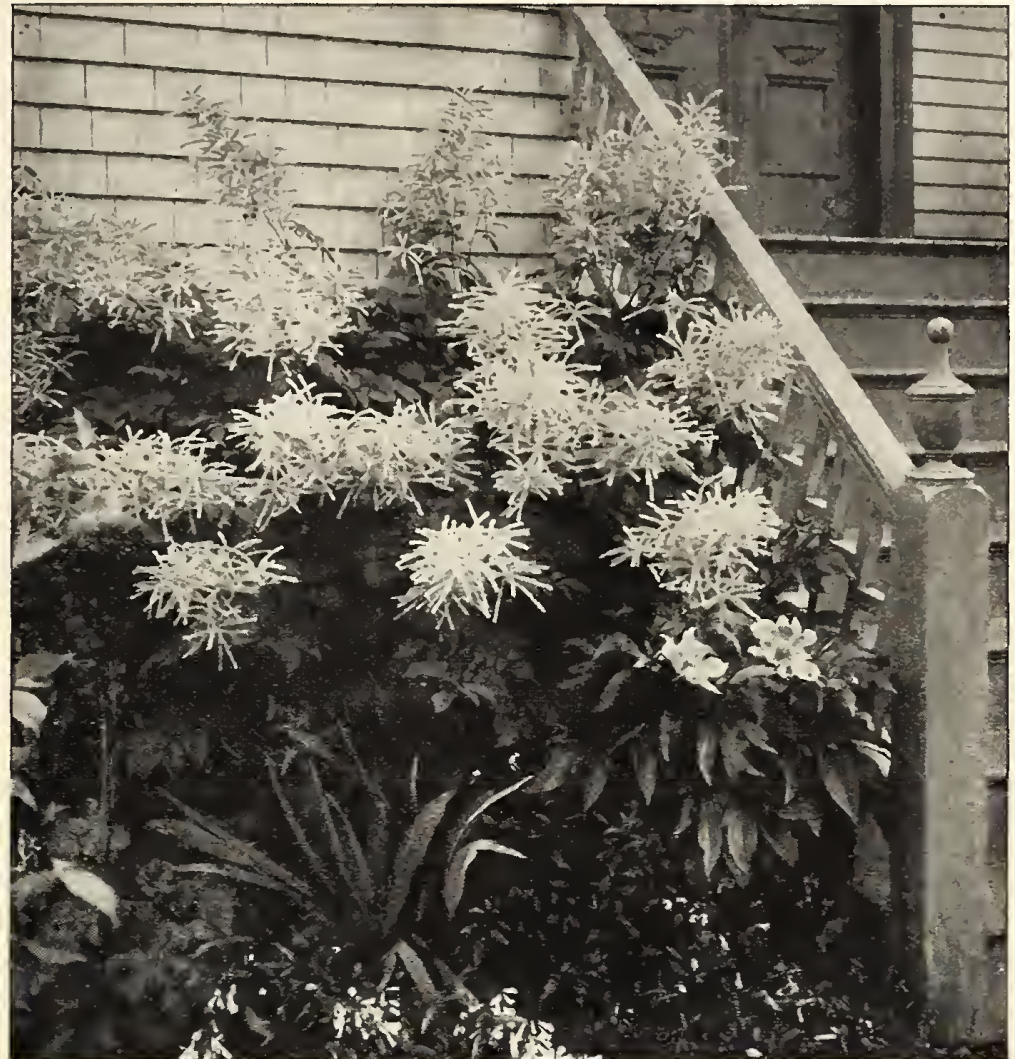

Common Goatsbeard makes tbis figbt of steps a tbing of beauty

remove them so that they will not interfere with the bulbs in the spring. We find it wise to put them into a coldframe because of the frequent transplanting. Those that are left in place the year round winter with a light covering of leaves without any trouble.

Varieties of Chrysanthemums are just as much a study as any other flowers. There are several types. The best are: the Pompon, with double, medium-sized flowers; the large-flowering, which are looser and more graceful; the singles, which are like large daisies; and the button type, which are exquisitely dainty. Choosing is a matter of personal taste to be governed somewhat by the

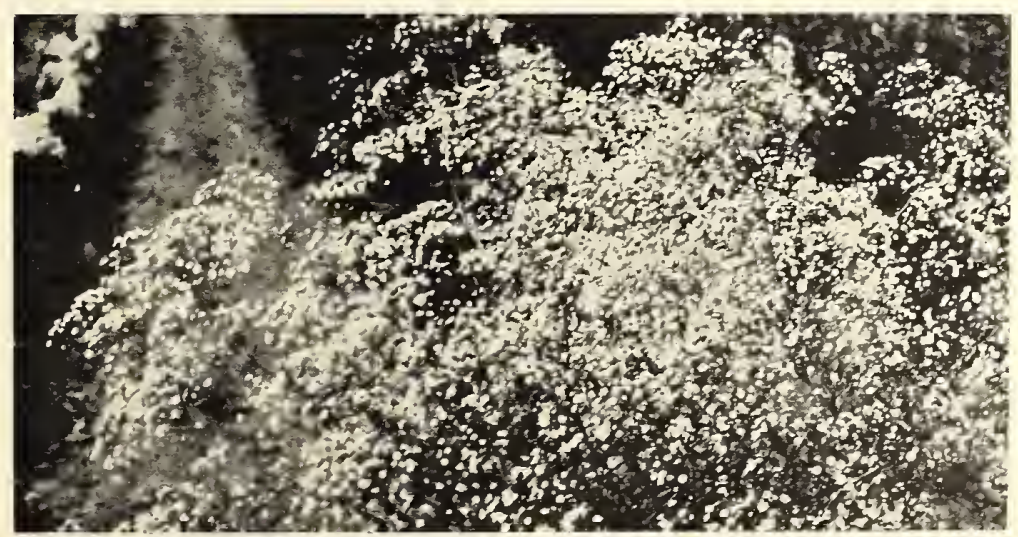

Gypsopbila, Bristol Fainy, is a veritable snowstorm of flouers 


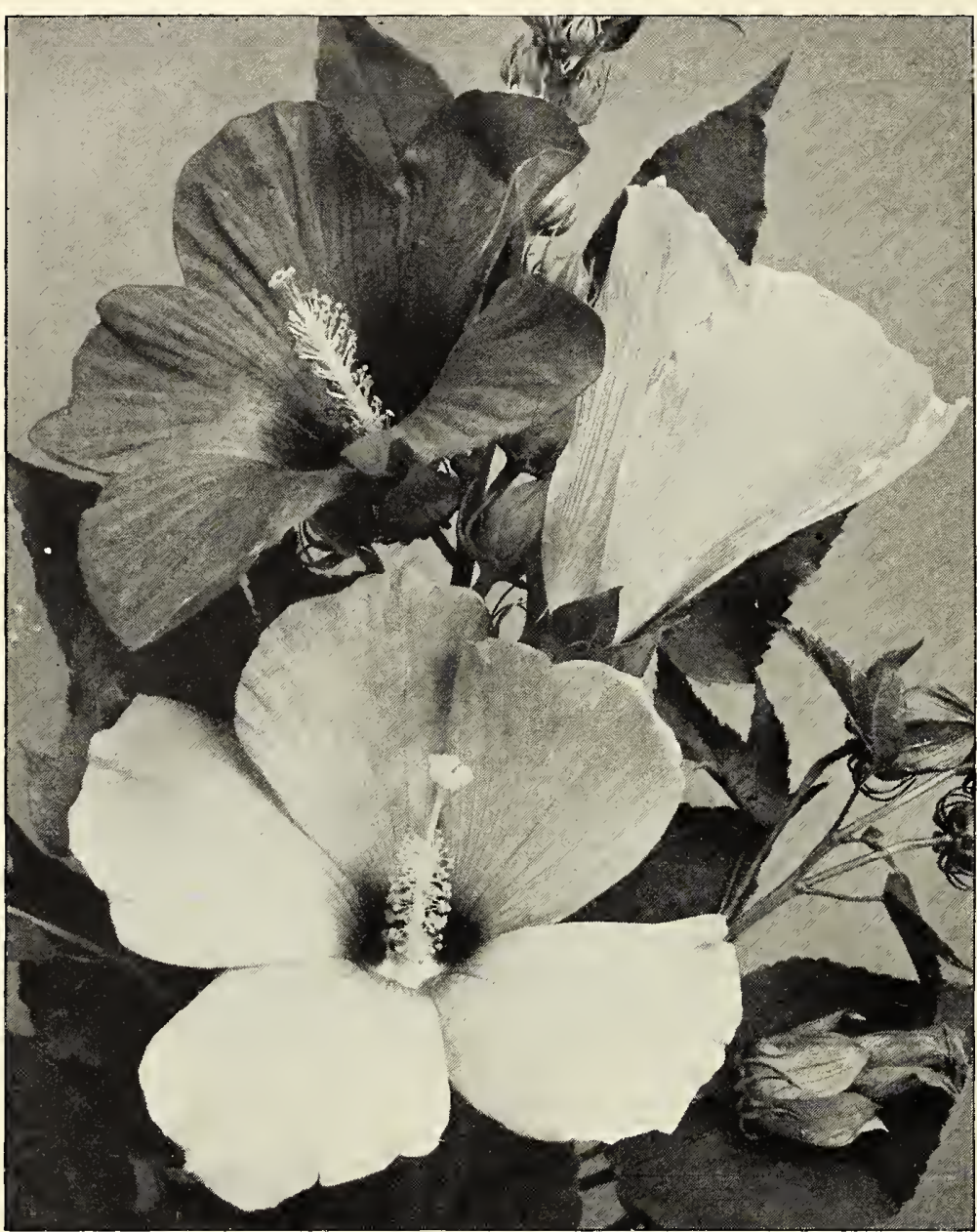

Mallow Marvels are truly marvelous in size of flowers and bandsome landscape effect

earliness or lateness of the first hard freezing. Chrysanthemum flowers and buds endure fairly hardy frosts with impunity, but a freeze that makes real ice will ruin them. In some localities, it is necessary to choose early-flowering types which come into bloom before their careers are cut short by winter.

Besides these most important "medium-taIl" plants-Irises, Peonies, Phloxes, and Chrysanthemums-there is an infinite range of subsidiary and, in some cases, almost indispensable plants of similar habit. You can scarcely call your place a garden if there are no Canterbury Bells in it, to supplement the Delphiniums in June. There are four colors, light blue, dark blue; white, and pink -all are good. White is best and there should be most of it. The dark blue is least desirable.

And what is an Iris garden if it is not full of Columbines? The lovely, delicate, airily balanced little birds of flowers are perfect companions for the solider texture of the Irises, and make a perfect picture when combined with them. Many of the wild or species Columbines are desirable denizens of the rock garden, but in the main garden, the long-spurred hybrids, particularly the strain developed by Mrs. Scott Elliott, are considered best. One
PLANTAIN LILY, continued

MAjor Pallida. Hosta sieboldiana. Very Iarge Iight green leaves and pale blue flowers. Dwarf, like Siebold's.

Siebold's. H. sieboldiana. Metallic, buish foliage; very dwarf. Flowers blue, on short stems.

Wavy Leaf. $H$. lancifolia. Decorative leaves with green, wavy edges and creamy white centers. Flowers white.

White. H.plantaginea. Handsome, bold foliage and tall stems with erect white flowers. Fine for cutting. June, July. 2 to $3 \mathrm{ft}$. $40 \mathrm{c}$. each, $\$ 4$ for 12 .

\section{Platycodon - Platycodon}

BALloON Flower. Platycodon grandiflorum. Slender, erect plants with bluish white and steel-blue bellflower-like blooms. July. 3 to $4 \mathrm{ft}$.

\section{Poppy - Papaver}

Oriental Poppy. Papaver orientale. Supremely stunning flowers of gigantic size and barbaric gorgeousness of color. May, June. 2 to $3 \mathrm{ft}$. All varieties listed below are $30 \mathrm{cts}$. each, $\$ 3$ for 12.
$\$ 20$ per 100

Apricot Queen. Large, silky petals of soft reddish apricot.

Bracteata. Enormous, blazing red blooms.

Brightness. Bright orange-scarlet.

Cerise Beauty. Extra-large; bright pink with purple blotch.

DUke of Teck. Very dark crimson.

ENFIELD BeAUTY. Rich salmon-pink, maroon base. Grand Mogul. Bright red. Excellent habit.

Mrs. Perry. Bright orange-apricot, shaded pink Oriental Hybrids. Assortment of best colors. Perry's White. White with purple-black base.

Princess Ena. Small, tulip-like flowers of orangesalmon.

Royal Scarlet. Profuse bloomer; medium size; rich scarlet.

Silverblick. SaImon, with blue blotches.

\section{Primrose - Primula}

Spechley Strain. Primula vulgaris. Dwarf, rosette-like plants with immense flowers in a vast range of colors and shades. Very lovely in a Iow border if slightly sheltered from the sun. 30 cts. each, $\$ 3$ for $12, \$ 20$ per 100 .

For otber Primroses, see Polyantbus and Primrose in the Rock Garden Section, page 48

\section{Pyrethrum - Chrysanthemum}

Parnted Lady. Cbrysanthemum coccineum. Longstemmed, daisy-like flowers of white, pink, and crimson, in varying shades, some single, semidouble, or crested. Lovely for cutting. May, June. 2 to $3 \mathrm{ft}$.

\section{Rocket - Hesperis}

DAME'S Rocket. Hesperis matronalis. Oldfashioned massing flower. Heads of pale purple and violet blooms. June, July. 2 to $3 \mathrm{ft}$.

DWARF Rocket. H. matronalis (nana candidissima). Not so tall. Flowers white.

\section{Rosemary • Rosmarinus}

Rosemary. Rosmarinus officinalis. A dwarf, bushy plant with grayish foliage valued for its aromatic scent. Flower blue and unimportant. 2 to $4 \mathrm{ft}$.

All plants on this page, except where noted, are $25 \mathrm{cts}$. each, $\$ 2.50$ for $12, \$ 18$ per 100 . Six of one kind sold at the 12 rate; 50 of one kind at the 100 rate. 


\section{Rudbeckia • Rudbeckia}

Newman's. Rudbeckia speciosa. Brilliant yellow, daisy-like flowers. Very showy for massed planting. July, August. 1 to $2 \mathrm{ft}$.

Golden Glow. $R$. laciniata. Showy, tall plants with great masses of double, dahlia-like flowers of rich yellow. August, September. 6 to $10 \mathrm{ft}$.

\section{Rue - Thalictrum}

Feathered Columbine. Tbalictrum aquilegifolium. Handsome plants with foliage like a columbine and tall stems bearing immense clusters of feathery whitish flowers. May, June. 1 to $3 \mathrm{ft}$.

Dusty Meadow Rue. $T$. glaucum. Fine, erect plants with great panicles of yellowish, misty flowers. June, July. 2 to $5 \mathrm{ft}$.

Maidenhair Rue. $T$. minus (adiantifolium). A dwarfish variety with lovely, delicately cut foliage, like a maidenhair fern. Flowers yellowish white. June, July. 1 to $2 \mathrm{ft}$.

Yunnan Rue. $T$. dipterocarpum. Exquisite panicles of rather large rosy purple flowers. The handsomest of the family August, September. 3 to $4 \mathrm{ft}$. $40 \mathrm{cts}$. each, $\$ 4$ for 12 .

\section{Sage - Salvia}

Autumn Sage. Salvia greggi. Bushy, shrubby plant covered with bright carmine-red flowers. JulyOctober. $2 \mathrm{ft}$.

Blue S.Ge. S. azurea. Wiry plants with spikes of sky-blue flowers with russet bases. Very attractive. July, August. 3 to $4 \mathrm{ft}$.

VIOLET SAGE. S. nemorosa. Dwarf rosettes of foliage from which rise slender spikes of violet flowers. Very fine in the border. July, August. 18 in. 35 cts. each, $\$ 3.50$ for $12, \$ 25$ per 100 .

Otber Sages described in Rock Garden Section, page 48.

\section{Scabiosa - Scabiosa}

C au casian. Scabiosa caucasica. Large lavender flowers of beautiful form on long stems for cutting. June-September. 2 to $3 \mathrm{ft}$. $30 \mathrm{cts}$. each, $\$ 3$ for $12, \$ 20$ per 100 .

White Caucasian. A white form of the same. 30 cts. each, $\$ 3$ for $12, \$ 20$ per 100 .

JAPANESE. S. japonica. Large flowers of clear light blue. Very handsome for cutting.

\section{Senecio - Ligularia}

Senecio. Ligularia clivorum. Stout plants bearing bright orange-yellow, daisy-like flowers with brown centers. August, September. 3 to $5 \mathrm{ft}$. 30 cts. each, $\$ 3$ for $12, \$ 20$ per 100 .

\section{Shasta Daisy - Chrysanthemum}

Alaska. Cbrysantbemum maximum. Large, white, single flowers with golden centers. All summer. $2 \mathrm{ft}$. $\$ 2$ for $12, \$ 12$ per 100 .

Giant Daisy. C. uliginosum. Giant plants with great heads of white, aster-like flowers. September, October. 5 to $7 \mathrm{ft}$. $\$ 2$ for $12, \$ 12$ per 100 .

KING EDward VII. C. maximum. Snow-white, cupped flowers on long stems. July-September. $2 \mathrm{ft}$. $\$ 2$ for $12, \$ 12$ per 100 .

Princess Henry. C. maximum. Pure white flowers of great size. One of the best. July-September. $2 \mathrm{ft}$. $\$ 2$ for $12, \$ 12$ per 100 .

Shasta Daisy. C. maximum. The original Burbank production. Flowers smaller than the others. July-September. $2 \mathrm{ft}$. $\$ 2$ for $12, \$ 12$ per 100 .

All plants on this page, except where noted, are $25 \mathrm{cts}$. each, $\$ 2.50$ for $12, \$ 18$ per 100 . Six of one kind sold at the 12 rate; 50 of one kind at the 100 rate.

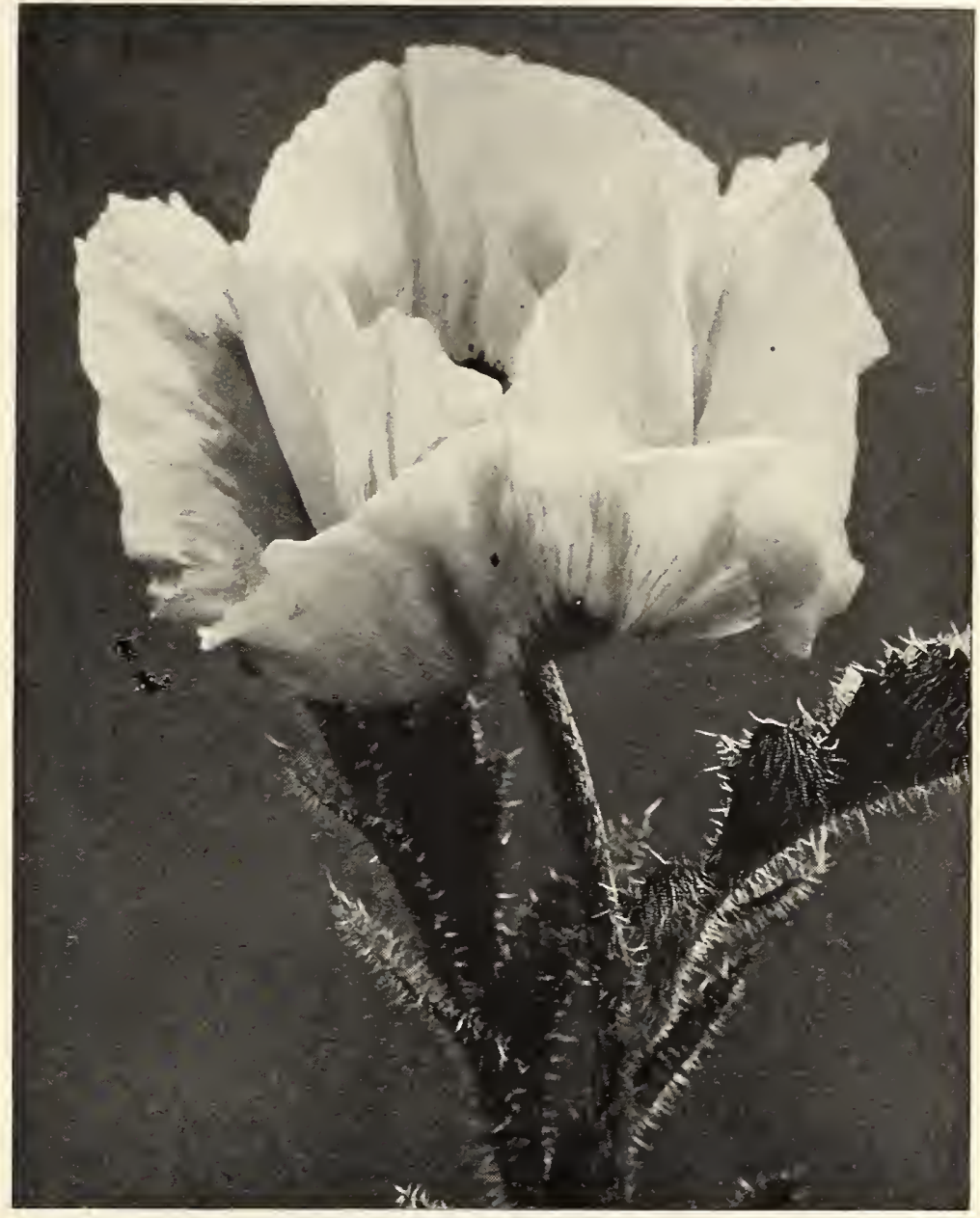

The soft color of Poppy, Mrs. Perry, cannot be sbown bere, but its lovely texture is apparent

always is particular to include the Rocky Mountain Columbine, or some form of it, in any collection, and blue-flowered specimens should be carefully preserved. They are the rarest, and for that reason, perhaps, the most desirable. We confess that the pink shades so much in demand do not make such an irresistible appeal to us as the blue tints, but you may think otherwise.

What would one do without the lovely pink and white Pyrethrums for cutting, and without their cousins, the Shasta Daisies in their different forms? Or the brilliant Coreopsis, the Gaillardias, the Stokesias, and the Scabiosas?-all slender-stemmed, Iongkeeping flowers, ideal for graceful bouquets and vases.

Room must be found for the Oriental Poppies whose enormous, silky flowers are every bit as astonishing in size as those of the gigantic Mallow Marvels which are so much taller and bloom later, with a brilliance and softness of color and texture unhoped for in flowers of such dimensions. The Day Lilies (Hemerocallis) must be included, too, because they are so much more like Lilies than many true Lilies are. They are so easy to grow, whereas most Lilies are a little finicky. Japanese Anemones are desired for 


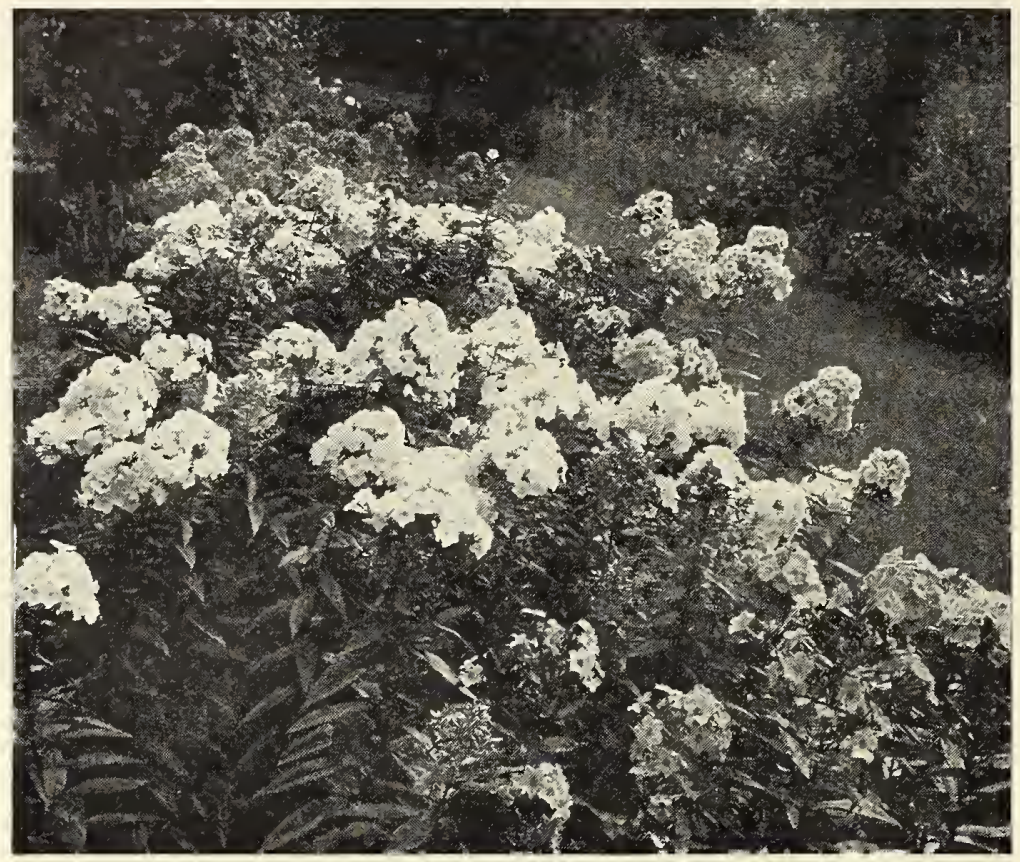

A planting of Hardy Pbloxes, summer's most important flowers. Several varieties are mixed bere

late summer cutting and for an elfin, other-worldliness of beauty which is simply indescribable. Platycodons are almost essential to follow the Bellflowers; Veronicas for the rare blue which otherwise would pass with the Delphiniums, and so on, and on.

\section{Front-Row Plants}

In the section devoted to rock plants, we have assembled most of the perennials which grow close to the ground and those which trail and mat. Phloxes, Sweet Williams, Sedums, Pinks, Prim-

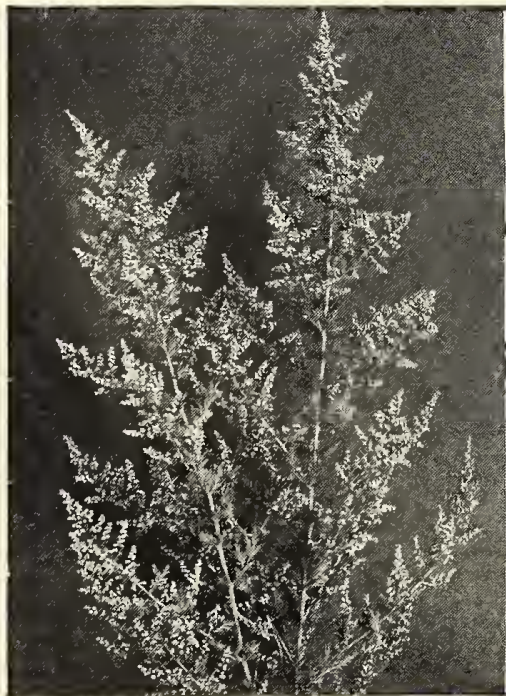

Wbite Mugwort-a beautiful silvery spray

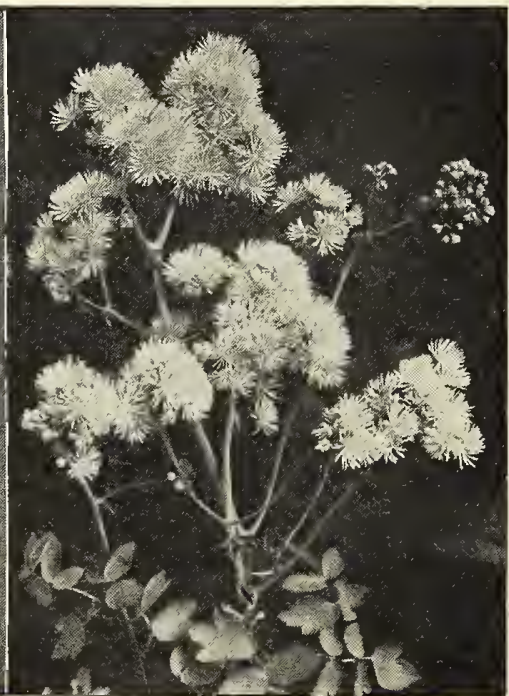

Featbered Columbine (Tbalictrum aquilegifolium)
Sidalcea $\cdot$ Sidalcea

Pratrie Mallow. Sidalcea murrayana. Spikes of pretty rose-pink flowers like small hollyhocks. July, August. 3 to $4 \mathrm{ft}$.

Rosy Gem. S. malvæflora. Flowers rich pink. July, August. 3 to $4 \mathrm{ft}$.

\section{Stenanthium - Stenanthium}

FEATHER Fleece. Stenantbium robustum. TaII, drooping spikes of pure white, feathery flowers turning pink as they age. July, August. 2 to $6 \mathrm{ft}$. 35 cts. each, $\$ 3.50$ for $12, \$ 25$ per 100 .

\section{Stokesia - Stokesia}

Stoke's Aster. Stokesia lavis. Handsome, asterlike flowers, 4 to 5 inches across, of pale blueviolet. July-September. 18 to 24 in.

White. S. lavis. The same, with white flowers.

\section{Sunflower • Helianthus}

Maximilian's. Heliantbus maximiliani. Rich yellow flowers about 4 inches across. August, September. 2 to $4 \mathrm{ft}$.

Mrss Melissh. H. scaberrimus. A fine variety with orange-yellow flowers. August, September. 4 to $5 \mathrm{ft}$.

Willow Leaf. $H$. orgyalis. Erect stems with numerous drooping narrow leaves and great sprays of smallish lemon-yellow flowers. September, October. 5 to $6 \mathrm{ft}$.

\section{Sweet William • Dianthus}

Beautiful bedding and border plants with flat heads of fringed, fragrant flowers of great beauty and variety. June, July. 1 to $11 / 2 \mathrm{ft}$.

Alba. Diantbus barbatus. Pure white flowers in large heads.

Double Everblooming. D. latifolius. Dark red, double flowers produced all summer.

Newport Pink. D. barbatus. Fine edging plant with great heads in all conceivable shades of rose and salmon-pink.

Rosea. D. barbatus. Bright rose-pink.

Scarlet Beauty. Blazing red flowers.

\section{Trollius - Trollius}

CоммоN. Trollius europæus. Globular flowers of rich yellow, like giant buttercups. May, June. 2 to $3 \mathrm{ft}$. $40 \mathrm{cts}$. each, $\$ 4$ for $12, \$ 30$ per 100.

JAPANESE. $T$. japonicus. Orange-yellow flowers on very low, dwarf plants. May. 4 to 8 in. 40 cts. each, $\$ 4$ for $12, \$ 30$ per 100 .

Mrxed. Selection of species and varieties of different shades of gold, orange, and yellow.

Orange Globe. T. europæus. Fine, ball-like flowers produced profusely in May. Rich orange. 40 cts. each, $\$ 4$ for $12, \$ 30$ per 100 .

Siberian. $T$. asiaticus. Orange-yellow flowers on long stems for cutting. Bronze foliage. May. $2 \mathrm{ft}$. 40 cts. each, $\$ 4$ for $12, \$ 30$ per 100 .

\section{Valerian - Valeriana}

Cомmon. Valeriana officinalis. Slender plants with flat clusters of intensely fragrant flowers. June, July, 2 to $4 \mathrm{ft}$. May be had in the following colors: Red, White, and Pink.

All plants on this page, except where noted, are 25 cts. each, $\$ 2.50$ for $12, \$ 18$ per 1 . S. Six of one kind sold at the 12 rate; 50 of one kind at the 100 rate. 
Veronica - Veronica

Amethystina. Veronica spuria. Beautiful spikes of delicate amethystine-blue flowers. May, June. $2 \mathrm{ft}$.

JAPANESE SPEedWELL V. longifolia subsessilis. Bushy plants with long spikes of rich blue flowers. July-September. 24 to 30 in. $30 \mathrm{cts}$. each, $\$ 3$ for 12 , \$20 per 100 .

Spiked Speedwell. $V$. spicata. Taller plant for sunny place. Long, purple-blue spikes of bloom. June, July. 2 to $3 \mathrm{ft}$.

White Speedwell. V. spicata. The same, with white flowers.

Otber Veronicas described in tbe Rock Garden Section,

Viola • Viola

Tufted Pansies. Viola cornuta. Lovely bedding and edging plants. Smaller than pansies, and more persistent; larger and bloom longer than violets. Some are especially effective in rockgardens, and several are described in the section devoted to Rock Plants, page 50. Most of them enjoy half-shade and some moisture. MayAugust. 6 to 8 in.

Ardwell Gem. Bright yellow.

Admirabilis. Violet-blue.

Black Prince. Rich velvety black.

Blue Perfection. A fine, clear, violet-blue. Large.

David Simpson.

Primrose Dame. Large flowers of soft primroseyellow.

Purple KIng. Rich, glowing purple.

SNOWDEN. Large white. \$2 for $12, \$ 14$ per 100.

Ali Colors Mixed. Fine assortment. $\$ 1.75$ for 12 , $\$ 12$ per 100

\section{Violet • Viola}

Princess of WAles. Viola odorata. True, fragrant single Violets, with long stems. May, June. 6 to 8 in.

\section{WaIlflower - Cheiranthus}

Common. Cbeirantbus cbeiri. Fine, old-fashioned, fragrant spikes of yellow, brown, and crimson blooms. April, May. $2 \mathrm{ft}$.

Otber Wallfowers described in Rock Garden Section, page 50 .

\section{Wormwood • Artemisia}

Dusty Mrller. Artemisia stelleriana. Soft, grayish foliage, useful for edging. Flowers unimportant. 1 to $2 \mathrm{ft}$

SOUTHERNWOOD. A. abrotanum. An aromatic, half-shrubby plant grown for its fragrance. Flowers unimportant. 3 to $5 \mathrm{ft}$.

Silver KING. A. stelleriana. Beautiful silvery foliage effective in landscape and for cutting. 30 in. 30 cts. each, $\$ 3$ for 12 , $\$ 20$ per 100 .

WhIte Mugwort. A. vulgatis (lactiflora). Handsome, sturdy plants with immense heads of small, white, fragrant flowers. August, September. 5 to $8 \mathrm{ft}$. 30 cts. each, $\$ 3$ for $12, \$ 20$ per 100 .

\section{Yucca - Yucca}

Aday's NeEdLe. Yucca flamentosa. Evergreen rosettes of large, pointed leaves and tall stems, with hundreds of white, bell-like flowers. June, July. 5 to $8 \mathrm{ft}$. $35 \mathrm{cts}$. each, $\$ 3.50$ for $12, \$ 25$ per 100.

All plants on this page, except where noted, are $25 \mathrm{cts}$. each, $\$ 2.50$ for $12, \$ 18$ per 100 . Six of one kind sold at the 12 rate; 50 of one kind at the 100 rate.

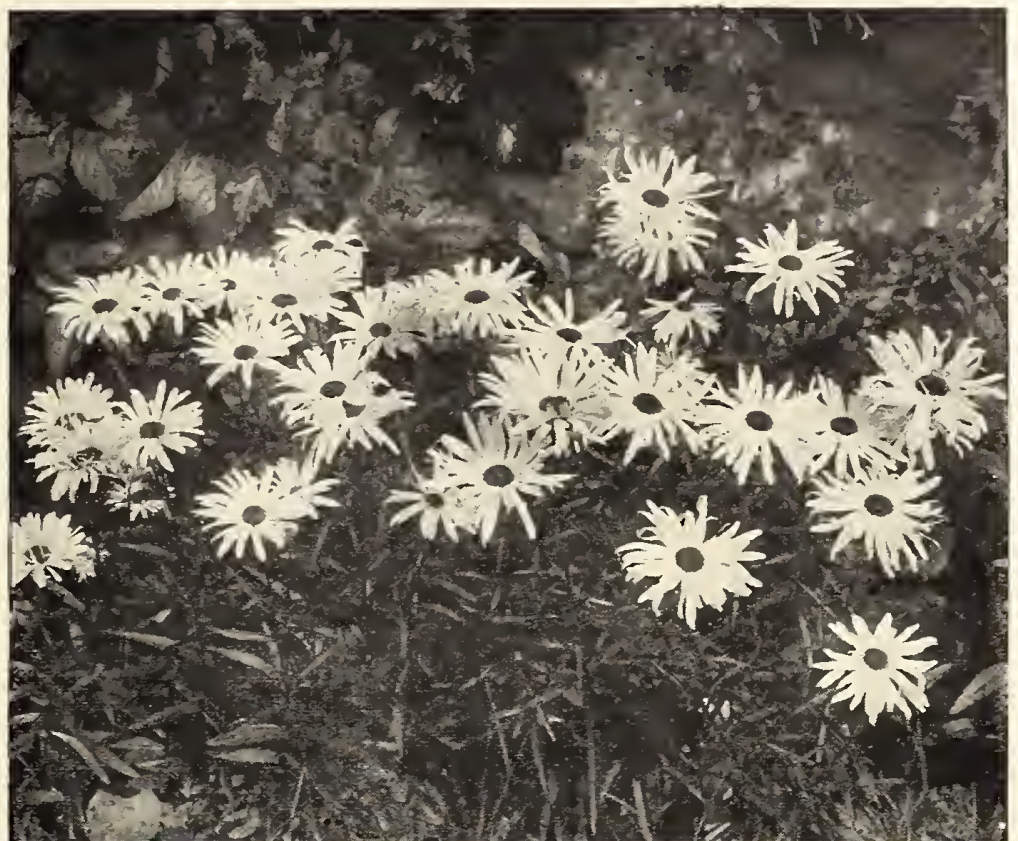

Sbasta Daisies make a fine, long-blooming border plant. Superb for cutting

roses, and Violas are plants of this type par excellence-but there is little use in repeating a mere catalogue here, piling up names of things like heaps of children's A B C blocks. A garden might soon become merely a clutter underfoot if discrimination and selection were not used. Each kind of flower is good and admirable in its place, just as each letter of the alphabet is a good and useful letter, but both the flowers and the letters must be organized, be made to spell words, before you get the real good out of them. That is, you must put your posies together so that they make some kind of sense, otherwise the garden will be a jumble and confusion. That is strictly your own affair.

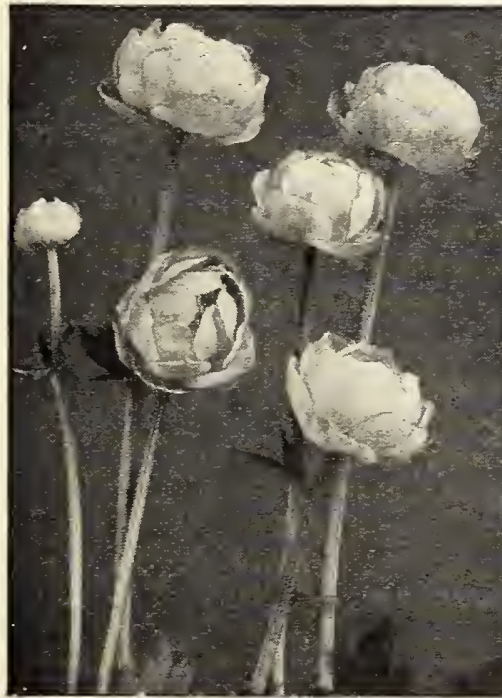

The quaint blooms of Trollius

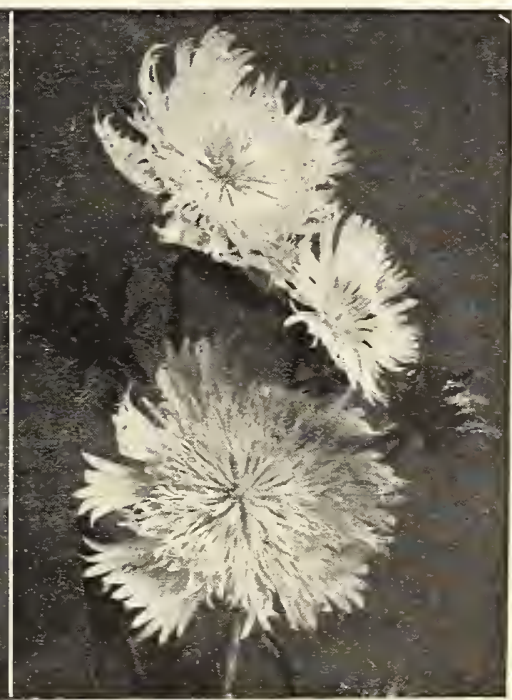

Anotber good cut-flower, Stokes' Aster 


\section{Plants Offered in This Book}

Abies concolor

Acanthopanax pentaphylium

Acer species

dasycarpum (wieri)

Achillea species and varieties . . . . 51

Aconite . . . . . . . . . . 51

Aconitum . . . . . . . . . . 51

Actæa

Actinidia arguta

Adam's Needle

Adiantum pedatum

Egopodium podograria (variegata)

Asculus hippocastanum

Ajuga reptans

Akebia quinata

Almond, Flowering

Althæa rosea

Althea

Alyssum

Amelanchier canadensis

Amorpha fruticosa

Ampelopsis

Amygdalus persica

Anchusa italica myosotidiflora

Anemone species

Japanese varieties

Angelica Tree

Anthemis tinctoria (kelwayi)

Aquilegia, Rock species

$$
\text { Others }
$$

Arabis alpina

Arborvitæ

Arenaria montana

Aristolochia sipho

Aronia arbutifolia

Arrhenatherum bulbosum (variegatum) 138

Arrow-wood . . . . . . . . . 23

Artemisia

Aruncus sylvester

Arundinaria japonica

Asclepias tuberosa

Ash, Mountain

Aster alpinus

Aster, Hardy varieties

Astilbe

Athyrium filixfemina

Aubrietia

Azalea

Baby's Breath

BaIIoon Flower

Dwarf

Bamboo

Baneberry

Baptisia australis

Barberry

Bayberry, Common

Beauty Berry

Beauty Bush

Bee BaIm

Belamcanda chinensis

BeIIflower

Chimney

Diamond

BeIlis perennis

Berberis

Berchemia racemosa

Betony, Woolly

Betula species

alba Iaciniata
Bignonia radicans

Birches

Cutleaf Weeping

Bittersweet, American

Evergreen

Japanese

Bleeding-Heart

Blue Bells

Bluet, Mountain

Bocconia

Boltonia

Box, Dwarf

Buckthorn

Buddleia davidi

Bugbane

Bugle, Carpet

Burning Bush

Buttercup, Double

Butterfly Bush

Butterfly Weed

Button Bush

Buxus sempervirens suffruticosa

Calimeris incisa

Callicarpa purpurea

Callirhoë involucrata

Calycanthus floridus

Camomile

False

Campanula carpatica

Other species

Candytuft

Canterbury Bells .

Caragana arborescens

Cardinal Flower

Carnation

Caryopteris incana

Cassia marilandica

Catalpa bignonioides nana

Catananche cærulea (alba)

Catchfly

$$
\text { German }
$$

Ceanothus americana

Cedar

$$
\text { White }
$$

Celastrus

Centaurea

Cephalanthus occidentalis

Cerastium biebersteini

Ceratostigma plumbaginoides

Cercis canadensis

Chamæcyparis

Cheiranthus allioni cheiri

Cherry, Japanese Weeping

Chionanthus virginica

Chokeberry, Red

Chrysanthemum species

Chrysanthemum varieties

Cimicifuga racemosa

Clematis varieties and species Other species

Clethra alnifolia

Clove Bush
Clover, Bush

Columbine, garden varieties

$$
\text { Feathered }
$$

Columbine, Rock species

Coneflower, Purple

Convallaria majalis

Coral Bells
Page
.28

3

6

.25

26

.25

.53

.44

.44

53

.53

12

12,26

12

.53

.44

.22

.53

12

.60

12

.12

.54

12

44

23

54

.53

.44

53

44

53

.12

. 44

54

.12

54

9
54

.49

.47

. 12

. 3

.25

.44

12

.44

48

. 20

50

. 65

. 6

.15

.13

62,63

54,55

.53

.26

.55

. 19

.13

59

55,56

.63

.45

.56

.59

46
Coral Berry . . Page

Coreopsis grandiflora

Cornus florida

Shrub species

Coronilla varia

Corylus americana

.21

7

13,14

6,7

Cranberry, Dwarf Bush . . . . . . . 23

High-Bush . . . . . . . . . . 23

Cratægus . . . . . . . . . 7,8

oxyacantha . . . . . . . . 7,26

Cupid's Dart . . . . . . . . . . .54

Currant . . . . . . . . . . . 13

Cydonia japonica . . . . . . . . 20

Cypress . . . . . . . . . . . 7

Cypripedium . . . . . . . . . . . . 47

Daisy, English . . . . . . . . . . 45

Michaelmas . . . . . . . . . 52

Shasta . . . . . . . . 63

Daphne cneorum . . . . . . . . 13

Day Lily . . . . . . . . . . . . .56

Delphinium grandiflorum chinense . . 46

Delphinium varieties . . . . . . . 56

Dennstaedtia punctilobula . . . . . 45

Deutzia . . . . . . . . 13

Dianthus barbatus . . . . . . . .64

caryophyllus . . . . . . . . . 54

deltoides . . . . . . . . . . 47

heddewigi . . . . . . . . . . 61

Iatifolius . . . . . . . . . 64

plumarius (semperflorens) . . . . . 47

Dicentra . . . . . . . . . . . . . 53

Diervilla . . . . . . . . . 24

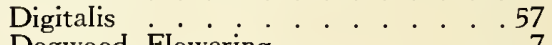

Dogwood, Flowering
Shrubby varieties
. . .

Dracocephalum ruyschiana . . . . .45

Dragonhead, False . . . . . . . 61

Siberian . . . . . . . . . . 45

Dropwort . . . . . . . . . . . 45

Dryopteris . . . . . . . . . . . 45

Dusty Miller . . . . . . . . . 65

Dutchman's Pipe . . . . . . . . 26

Echinacea purpurea . . . . . . . 56

Echinops ritro . . . . . . . . . . 57

Elæagnus . . . . . . . . . . . . 19

Elder . . . . . . . . . . . . . . . 14

Eleagnus . . . . . . . . . . . . . 19

EIm . . . . . . . . . . 3

Eulalia . . . . . . . . . . . 58

Euonymus . . . . . . . . . . 22

Exochorda grandiflora . . . . . . . 19

Fatsia japonica . . . . . . . . . . 14

Feather Fleece . . . . . . . . . . . 64

Ferns . . . . . . . . 45, 46

Fescue, Blue . . . . . . . 46, 57

Festuca glauca . . . . . . 46, 57

Filipendula hexapetaIa (fं.-pI.) . . . .45

palmata . . . . . . . . 60

purpurea . . . . . . . . . . . 60

ulmaria . . . . . . . . . . 60

Fir

Flax, Perennial . . . . . . . . . . 46

Flowers, Hardy Garden . . . . . 51-65

Forget-me-not . . . . . . . . 46

Forsythia . . . . . . . . . . . . 15

Foxglove . . . . . . . . 57

Fringe Tree . . . . . . . . . . . . 15 
Gaillardia

Garland Flower

Juniper, Irish

Pfrtzer's

Prostrate

Savin's

Genista tinctoria (virgata) . . . . 15

Gentian ... . . . 46

Germander . . . . . . . . 49

Geum . . . . . . . . . . . . .

Ginkgo . . • . . . . . . . . . . 4

Goatsbeard, Common ‥ . . . .57

Gold Flower . . . . . . . . . . . . . . 15

Goutweed . . . . . . . . . . 57,58

Grape, Amur . . . . . . . . . . . . 27

Frost . . . . . . . 26

Summer

57.58

Grasses :

$46-58$

Halesia tetraptera

21

Hamamelis virginiana .0 .0 .0 .24

HarebeII

Hawthorn

English

Thicket

Juniperus chinensis (pfitzeriana)

communis aurea

communis (depressa)

communis hibernica

sabina

virginiana

virginiana (glauca)

Kalmia latifolia

Kerria

Kniphofia

Kolkwitzia amabilis

Kudzu Vine

Lace Shrub

Lady's Slipper

Larch, European

Larix europæus

Larkspur

Lathyrus

LaureI, Mountain

Lavandula officinalis

Lavender, Sea

Sweet

Leadwort, Blue

Lespedeza formosa

Leucothoë catesbæi

Liatris

Ligularia clivorum

Ligustrum

ovalifolium

vulgare.

Lilac

Lilies

Lilium

Lily, Blackberry

Day

Dwarf

Plantain

Lily-of-the-Valley

Limonium latifolium

Linum

Lobclia cardinalis

Locust, Pink

Lonicera, shrub species Vines

Loosestrife

Japanese

Rose

Lupine

Lupinus

Lychnis chalcedonica

coronaria

coronaria (alba)

coronaria (atrosanguinea)

haageana

Haage's

viscaria (splendens)

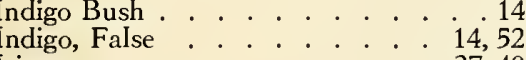

Irises . .
Intermediate
Japanese

Japanese Group . . . . . . . . . 40

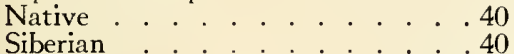

$37-39$

Tall Bearded

.16

Ivy

Lycium chinense .

Lysimachia clethroides nummularia

Lythrum

Maidenhair Tree

Mallow, Crimson Eye

Poppy-

Prairie

Rose

Mallow Marvels

Maltese Cross

Malus

Page

17

17

. 17

17

8

17

8

17

3

17

17
17

Jacob's Ladder .48

Jersey Tea

Judas Tree

Juniper, Golden
8
Maple, Norway

Silver .

Sugar

Wier's Cut lcaf

Marguerite, Kelway's

Matrimony Vine

Meadowsweet

Mertensia virginica

Milkweed .

Miscanthus

Moccasin Flower

Mock Orange

Monarda

Moneywort

Monkshood

Morus alba (pendula)

Moss, Golden

Mountain-Ash

Mugwort, White

Mulberry, Weeping

Mullein

Myosotis scorpioides (semperflorens) .46

Myrica carolinensis . . . . . . . 12

Myrtle

Nanny Berry

Ninebark

Oak, Pin

Enothera fruticosa (youngi)

glauca

missouriensis

speciosa (rosea)

Oleaster

Olive, Russian

Orchid

Osier

Osmunda

Oxydendrum arboreum

Pachysandra terminalis

Painted Lady

Pansies, Tufted

Papaver orientale

Pea, Perennial

Pea Tree

Peach Bells

Peach, Double-flowering

Pearl Bush

Pennisetum alopecuroides (japonicum) 57

Pentstemon

Peonies

Pepper Bush, Sweet

Periwinkle

Philadelphus

Phlox amoena

arendsi

decussata

divaricata

subulata

Phlox, Hardy Perennial

Wild Blue

Physalis francheti

Physocarpus opulifolius

Physostegia virginiana

Picea canadensis

excelsa

pungens (glauca)

pungens kosteri

Pieris mariana

Pine, Austrian

Mugho

Scotch

Pink Bells

Pinks . 
Pinks, Japanese Mullein

Pinus montana (mughus) nigra sylvestris

Pinxter Flower

Plane, European

Plantain Lily

Platanus orientalis

Platycodon grandiflora grandiflorum (mariesi)

Plumbago, Larpent's

Plum, Flowering Purple-leaved

Polemonium

Polyanthus

Polygonum auberti

Polypodiaceæ

Polystichum acrostichoides

Poplar, Lombardy Meyer's

Poppy, Oriental Plume

Poppy-Mallow

Populus meyeri nigra (italica)

Primrose, Evening

Japanese

Kashmir

Spechley Strain

Primula species vulgaris

Privet, Amur

California

European

Lodense

Regel

Prunus cerasifera (pissardi) glandulosa

subhirtella (pendula) triloba

Pseudotsuga douglasi

Pteretis nodulosa

Pueraria thunbergiana

Pyracantha coccinea

Pyrethrum

Qucrcus palustris

Quince, Flowering

Ranunculus acris

Raspberry, Purple-flowering

Rcdbud .

Rhamnus cathartica

Rhodora canadensis

Rhododendron

Rhodotypos kerrioides

Rhus canadensis

Ribes

Robinia hispida

Rock Cress

Rocket, Dame's

Rock-Garden Plants

Rosa

Rose Bay

Rose, Shrub

Rose-Acacia

Rosemary

Roses

Climbing

Hybrid Perpetual

Hybrid Tea

Miscellaneous

Rosmarinus officinalis

Rubus odoratus
Page

61

19

5

5

. 11

61,62

5

62
48

48

9

9

48
48

28

45

45

5,9

5

62
53

44

5

45,57

48

48

62

48

62

28

20, 28

20

28
28

9

9
10

6

9

4

46

28

15

62

4

20

53
20

20

12,26

20

20

20

22,23

13

21

48

62

43-50

20, 21

. 20

.21

62

$20,21,29-33$

29,30

.33

31-33

33

62

20
Rudbeckia

Rue, Meadow

Page

Sage, Autumn

Blue

Round Top

Silvery

Violet

Salix babylonica

caprea

pentandra

salamoni

vitcllina (britzensis)

vitellina (pendula)

Salvia argentea

azurea

globosa

greggi

nemorosa

Sambucus

Sandwort, Mountain

Saponaria ocymoides

Saxifraga . . . . . . . . . . 49

Scabiosa . . . . . . . . 63

Sedum ...... 49

Senecio . . . . . . . . . . . . . 63

Senna, American . . . . . . . . . 54

Service Berry

Shadbush

Sidalcea

Silene

Silver Bell

Silver Lace Vinc

Smoke Tree

Sneezewort

Snowball

Snowberry

Snow-in-Summer

Soapwort

Sorbaria sorbifolia

Sorbus aucuparia

Sourwood

Southernwood

Spcedwell, Creeping

Japanese

Rock

Spiked

White

Spindle Tree

Spiræa varieties

Blue

False

Spruce, Blue Colorado

Koster's Blue

Norway

White

Spurge, Japanese

Stachys Ianata

Stagger Bush

Statice

Broad-Ieaved

Stenanthium robustum

Stephanandra flexuosa

St. John's-Wort

Stokcsia Iævis

Stonecrop

Strawberry Bush

trawberry Shrub

Styrax

Sumac

Sundrops, Fraser's

Ozark

Pink

Young's

Sunflower
Supplejack, Japanese

Page

Sweet Shrub . . . . . . . 23

Sweet Spire . . . . 16

Sweet William . . . . . . . 64

Symphoricarpos . . . . . . . 21

Syringa specics . . . . . . . . . 17

Tamarisk species . . . . . . . . . 23

Taxus canadensis . . . . . . . . 24

cuspidata . . . . . . . . . . . 9

cuspidata brevifolia . . . . . . . 24

Teucrium chamædrys . . . . . . . . . . 49

Thalictrum species . . . . . . . . 63

Thistle, Globe . . . . . . . . . .57

Thorn . . . . . . . . . . . 7,8

Thrift . . . . . . . . 49

Thuja occidentalis and vars . . 6, 10, 25

Thyme, Woolly . . . . . . . 50

Thymus serpyllum (lanuginosus) . . $\quad .50$

Trees, Ornamental . . . . 6-9

Shade and Woodland . . . . . . 3-5

Trollius species and varieties . . . . . 64

Trumpet Vine ..... 28

Tsuga canadensis

caroliniana 4

Tunica saxifraga

Tunic Flower . . . . . . . . . . . . . . 50

UImus . . . . . . . . 3

Umbrella Tree . . . . . . . . . 9

Valerian, Common . . . . . . . . . 64

Greek . . . . 48

Richardson's

Valeriana officinalis $\cdot \cdot c^{\circ} \cdot \cdot \cdot \cdot 64$

Verbascum . . 60

Veronica amethystina . . . . 65

longifolia subsessilis . . . . . . 65

repens . . . . . . . . . 50

rupestris ... 50

spicata . . . . . . . . . 65

spuria ... . . . 65

teucrium rupcstris . . . . . . . 50

Vetch, Crown . . . . . . . . . . . 44

Viburnum species . . . . . . . . 23

Vinca minor . . . . . . . . . . . .28

Viola cornuta varieties . . . . 50,65 odorata . . . . . . . . . . 65

Violet, Princess of Wales . . . 65

Violets, Horned . . . . . . . . . 50

Virginia Creeper . . . . . . . . . 27

Vitis . . . . . . . . . . 26

Wallflower, Common . . . . . . . . 65

Siberian .50

Weigcla varieties . . . . . . . . 24

Willow, Babylon Weeping . . . . 5

Bronze

Golden Weeping . . . . . . 5

Laurel . . . . 24

Pussy ; Weeping . . . . . . . . . . 52

Winter Creeper . . . . . . . . . . 26

Wisteria . . . . . . . . . 28

Witch-Hazel . . . . . . . . . . . 24

Withe-Rod . . . . . . . . . . . 23

Woadwaxen, Tall ..... 15

Woodsia . . . . . . . . . 45

Wormwood . . . . . . . . 65

Xanthorrhiza apïfolia . . . . . . 24

Yarrow, Pink . . . . . . . . . . 51

Yellow-root, Shrub . . . . . . . . . 24

Yew, American . . . . . . . . . 24

Dwarf Japanese . . . . . . . . 24

Japanese . . . . . . . . . . . 9

Yucca filamentosa 


\section{Orders Subject to the Following:}

TERMS OF PAYMENT. Invariably cash on delivery. Under no circumstances will we ship C. O. D. We deliver the goods and mail bills at the same time, and expect payment within a few days. People unknown to us please send cash or references with orders.

PRICES AND PACKING. Prices in this Catalogue are subject to stock offered being unsold when ordered, and include aII charges for packing.

Six plants of a kind will be furnished at the dozen rate; 50 or more at the 100 rate; 500 or more at the 1,000 rate. Less than 6 plants of one kind or variety will be sold only at the single rate.

All prices f. o. b. shipping point.

FORWARDING. Shipments will be forwarded exactly as directed, but when instructions are not given we will forward by shortest and safest route. We recommend that aII Herbaceous Plants be shipped by express.

CLAIMS FOR DAMAGES. We guarantee the safe arrival of plants shipped by Express and insured Parcel Post. Goods shipped by freight travel at customer's risk, and claims for loss or damage while in transit must be made to the freight company.

PARCEL POST. Small packages can be sent by parcel post. Such shipments will be insured, insurance and postage to be paid by the customer.

SHIPPING DIRECTIONS. Please give exact shipping directions, stating whether the stock is to be shipped by freight or express, and by what route. Early orders for trees and bulbs can be shipped by freight.

INSPECTION AND FUMIGATION. Our stock is regularly inspected, and certifrcates will be sent with each shipment. Stock will be fumigated when requested or when the state laws require it.

IMPORT ORDERS are taken subject to failure of crops and to restrictions of quarantines promulgated by the Federal Horticultural Board.

NO AGENTS EMPLOYED. We employ no agents whatever, but do an exclusive retail business direct with our customers.

PLEASE PRINT YOUR NAME AND ADDRESS on your order. Many times it is extremely difficult to read these two important parts of an order, and the shipment may go astray.

GUARANTEE. We guarantee all nursery stock furnished by us to be first class and true to name. We do not guarantee it to grow, or stand good for the result in any way. Complaints must be made immediately upon receipt of stock. There are so many causes for failure over which we have no control, that we can assume no responsibility after the stock is delivered in good order to the transportation company. Poor soil, changeable weather, ignorant or careless culture-all contribute to failure. A Catalogue as comprehensive as this must of necessity offer some varieties of difficult cuIture; when these are ordered we presume the people ordering have the knowledge needed for that culture. Successful gardening requires knowledge, enthusiasm, and perseverance, and these we cannot supply. 


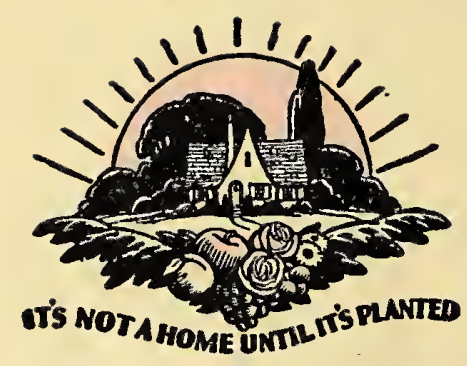

